Prepared in cooperation with the Carson Water Subconservancy District

\title{
Assessing Potential Effects of Changes in Water Use With a Numerical Groundwater-Flow Model of Carson Valley, Douglas County, Nevada, and Alpine County, California
}

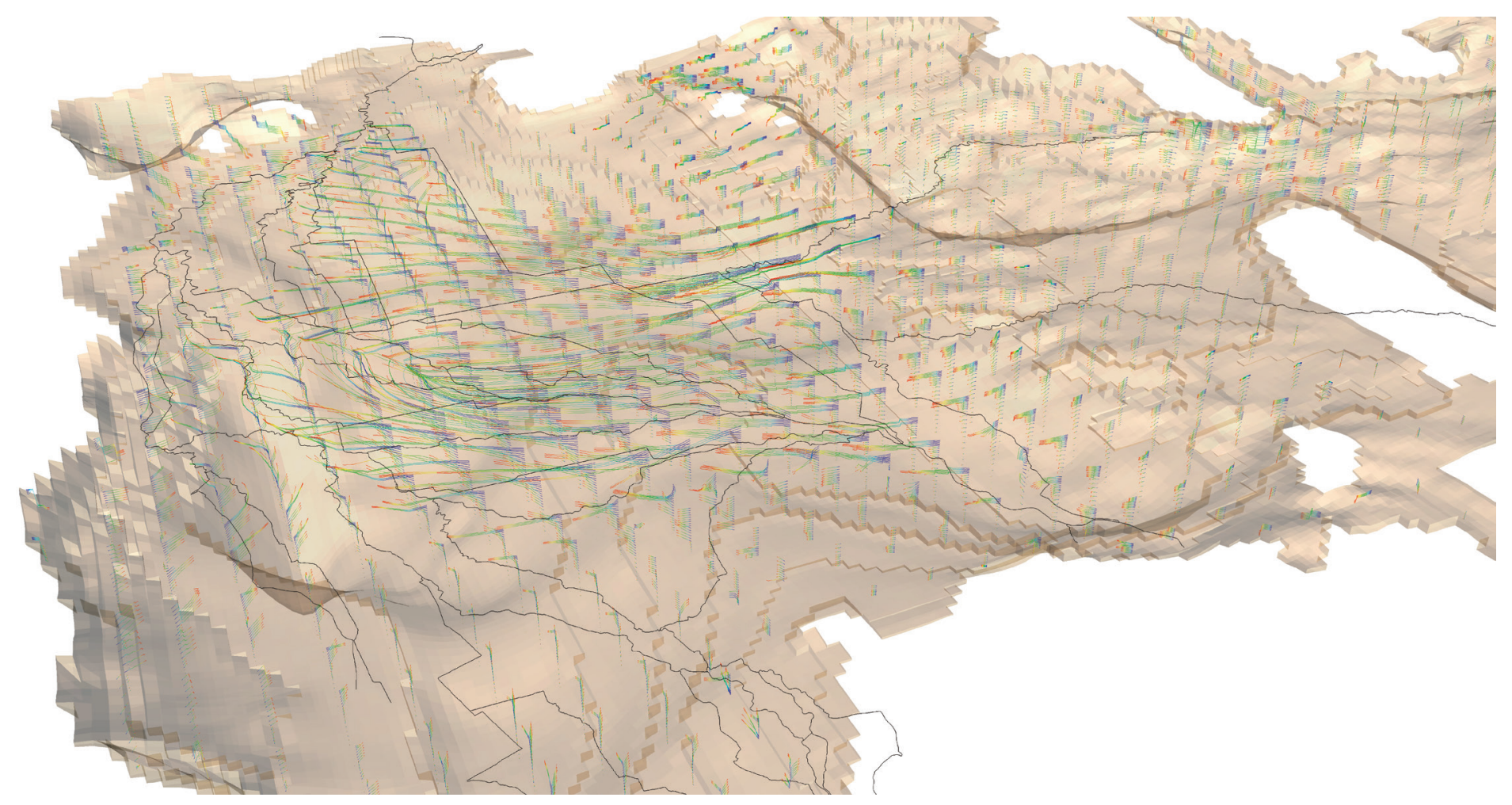

Scientific Investigations Report 2012-5262 
Cover photograph: Simulated rate and direction of groundwater flow in Carson Valley. 


\section{Assessing Potential Effects of Changes in Water Use With a Numerical Groundwater-Flow Model of Carson Valley, Douglas County, Nevada, and Alpine County, California}

By Richard M. Yager, Douglas K. Maurer, and C.J. Mayers

Prepared in cooperation with the Carson Water Subconservancy District

Scientific Investigations Report 2012-5262 


\title{
U.S. Department of the Interior \\ KEN SALAZAR, Secretary \\ U.S. Geological Survey \\ Marcia K. McNutt, Director
}

\author{
U.S. Geological Survey, Reston, Virginia: 2012
}

For more information on the USGS - the Federal source for science about the Earth, its natural and living resources, natural hazards, and the environment, visit http://Www.usgs.gov or call 1-888-ASK-USGS.

For an overview of USGS information products, including maps, imagery, and publications, visit $h t t p: / / w w w . u s g s . g o v / p u b p r o d$.

To order this and other USGS information products, visit http://store.usgs.gov.

Any use of trade, product, or firm names is for descriptive purposes only and does not imply endorsement by the U.S. Government.

Although this report is in the public domain, permission must be secured from the individual copyright owners to reproduce any copyrighted materials contained within this report.

Suggested citation:

Yager, R.M., Maurer, D.K., and Mayers, C.J., 2012, Assessing potential effects of changes in water use with a numerical groundwater-flow model of Carson Valley, Douglas County, Nevada, and Alpine County, California: U.S. Geological Survey Scientific Investigations Report 2012-5262, 73 p. 


\section{Contents}

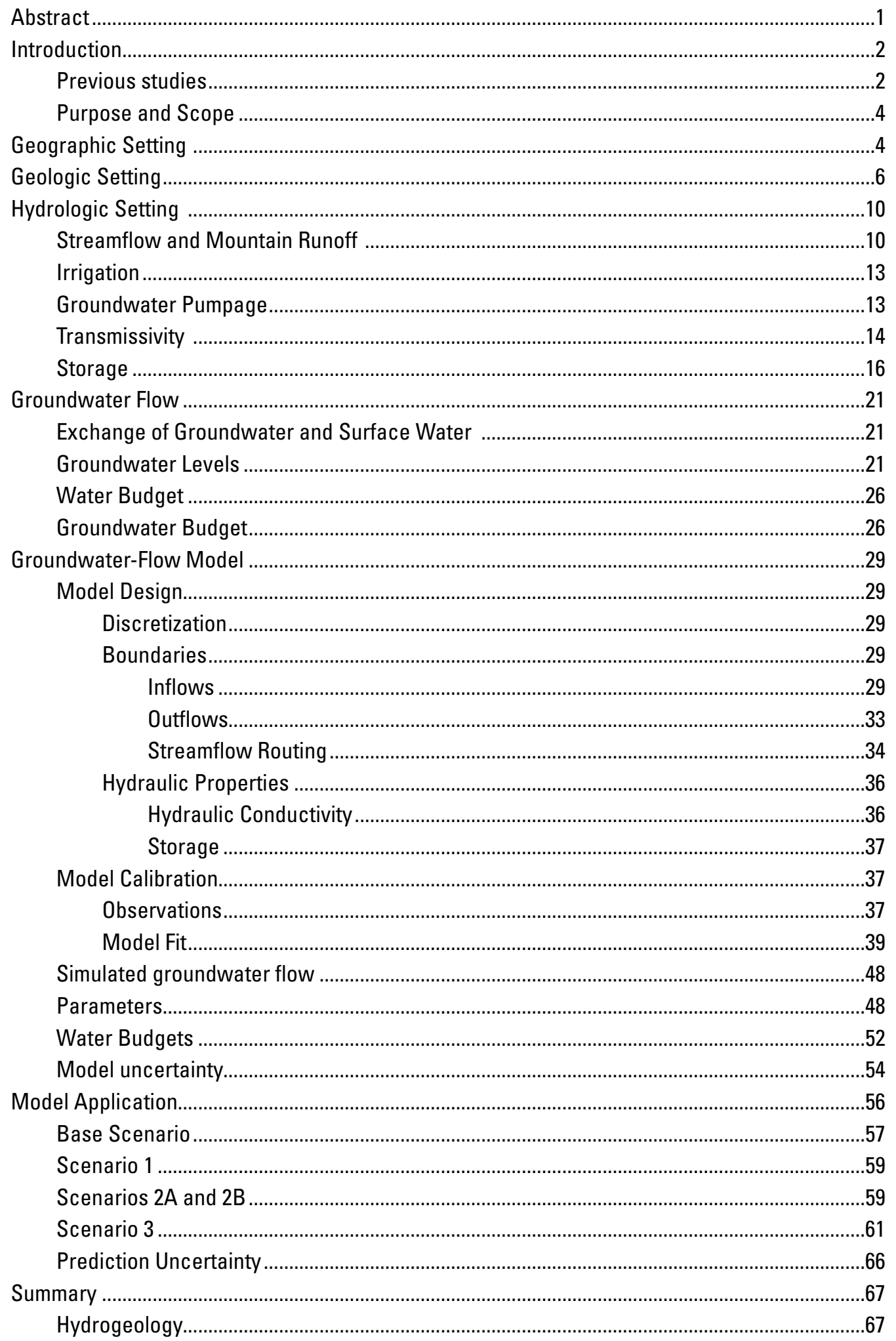




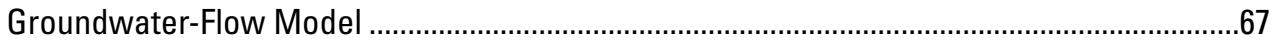

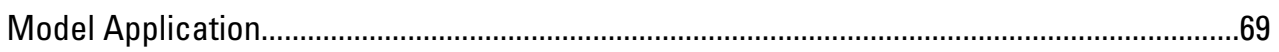

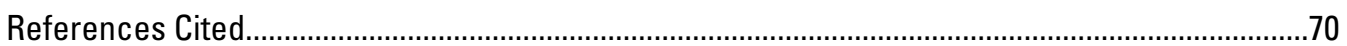

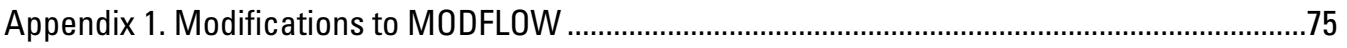

Appendix 2. Modifications to PCGN Solver .........................................................................................83

\section{Figures}

1. Map showing location of the Carson River basin and the Carson Valley study area ............ 3

2. Map showing vegetation and land use in and near Carson Valley, 2005 ................................. 5

3. Graph showing annual precipitation at Minden, Nevada, for period of record (1930-2005) and average annual precipitation for 1971-2000; Palmer Drought Severity Index for western Nevada, 1930-2005

4. Map showing locations of towns and approximate depth to water (spring 2006) in Carson Valley

5. Map showing geologic units, depth to bedrock, faults, and locations of aquifer tests; selected wells likely penetrating Tertiary sediments; and east-west hydrogeologic cross section

6. Hydrogeologic cross-section $A-A^{\prime}$ and conceptual model of groundwater flow paths in Carson Valley

7. Map showing location of U.S. Geological Survey and Federal Water Master gages, perennial and ephemeral watersheds, areas where effluent has been applied for irrigation, and irrigation distribution system in Carson Valley

8. Graph showing groundwater pumpage for irrigation, municipal, domestic and other uses in Carson Valley, 1946-2005 ....

9. Graph showing relation between transmissivity estimates obtained from specific capacity and aquifer-test data

10. Map showing location of wells with specific-capacity data from drillers' logs .

11. Graph showing distribution of transmissivity in wells with screen lengths greater than 99 feet in Quaternary and Tertiary sediments.

12. Map showing location of wells with screened lengths greater than 99 feet and the kriged distribution of log transmissivity

13. Map showing geologic units and the estimated distribution of specific yield in basinfill sediments of Carson Valley from Dillingham (1980)

14. Map showing water-table altitude in Carson Valley, spring 1998

15. Graph showing water-level fluctuations,1981-2006, in wells on the western alluvial fans; shallow wells on the valley floor; deep flowing wells on the valley floor; deep irrigation wells near the valley floor; wells on the eastern side of the valley; and wells with water levels affected by changes in water use

16. Map showing components of the mean annual water budget for Carson Valley, water years 1990-2005.

17. Diagram showing inflow and outflow of water from agricultural use; domestic use ........... 28

18. Map showing model domain and distribution of Quaternary and Tertiary sediments in Carson Valley groundwater model and location of hypothesized Hot Springs Fault ......... 30

19. Map showing assumed lateral and vertical distribution of Quaternary and Tertiary sediments. 
20. Map showing distribution of mountain-front recharge, effluent application, and evapotranspiration in Carson Valley groundwater model

21. Map showing location of municipal, domestic, and irrigation supply wells in Carson Valley groundwater model.

22. Graph showing residual plots for simulated absolute heads in Carson Valley groundwater model: relation between simulated and observed values; relation between simulated values and weighted residuals

23. Map showing simulated water table in the summer quarter of water year 2005, locations and rates of surface-water exchange, and spatial distribution of absolute-head residuals

24. Graphs showing residual plots for simulated water-level changes in the Carson Valley groundwater model: relation between simulated and observed values; relation between simulated values and weighted residuals

25. Map showing simulated and observed water-level hydrographs for selected wells in the Carson Valley

26. Graphs showing residual plots for simulated flows in Carson Valley groundwater model: relation between simulated and observed values; relation between simulated values and weighted residuals

27. Graphs showing simulated and observed flow hydrographs for streamflow gaging stations in the Carson Valley: Carson River near Carson City; Carson River near Genoa; West Fork Carson River at Dressler Lane; Brockliss Slough at Ruhenstroth dam; and Brockliss Slough at Scossa box.

28. Graph showing simulated and observed loss in flow in the Carson River, water years 1971-2005

29. Simulated water table along section $A-A^{\prime}$ in the summer quarter of water year $2005 \ldots \ldots . . . .48$

30. Image showing simulated rate and direction of groundwater flow in Carson Valley............. 49

31. Maps showing simulated rate of recharge from streamflow diverted to irrigated fields in Carson Valley in water year 2005: spring quarter; summer quarter.

32. Graph showing composite-scaled sensitivities of optimal parameters in Carson Valley groundwater model

33. Graph showing groundwater budgets simulated for water years 1971-2005. 52

34. Graphs showing cumulative water budgets simulated for water years 1971-2005: inflow; outflow...

35. Graphs showing projected Palmer drought severity index; range in pumping specified in 55-year predictive simulations.

36. Map showing water-table decline from 2010 through 2060 simulated by the base scenario using the Carson Valley groundwater model

37. Graph showing annual groundwater budgets, 2006-60 simulated by base scenario

38. Map showing additional groundwater withdrawals included in scenario 1 , additional water-table decline from 2010 through 2060 simulated by scenario 1 compared to the base scenario, and simulated water-level hydrographs at selected wells for the base scenario and scenario 1

39. Graphs showing annual groundwater budgets from 2051 through 2060 simulated by base scenario and scenario 1; annual loss in flow in the Carson River, 2051-60 predicted by base scenario and scenario 1

40. Map showing additional groundwater withdrawals included in scenario $2 A$, additional water-table decline 2010-60 simulated by scenario $2 \mathrm{~A}$ compared to the base scenario, and simulated water-level hydrographs at selected wells for the base scenario and scenario $2 \mathrm{~A}$ 
41. Map showing additional groundwater withdrawals included in scenario $2 B$, additional water-table decline $2010-60$ simulated by scenario $2 \mathrm{~B}$, and simulated water-level hydrographs at selected wells for base scenario and scenario $2 \mathrm{~B}$

42. Graphs showing annual groundwater budgets, 2051-60 simulated by base scenario and scenario 2A; annual loss in flow in the Carson River, 2051-60 predicted by base scenario and scenario $2 \mathrm{~A}$

43. Graphs showing annual groundwater budgets, 2051-60 simulated by base scenario and scenario 2B; annual loss in flow in the Carson River 2051-60 predicted by base scenario and scenario $2 \mathrm{~B}$

44. Map showing additional groundwater withdrawals included in scenario 3 , agricultural land removed from irrigation, additional water-table decline 2010-60 simulated by scenario 3 , and simulated water-level hydrographs at selected wells for base scenario and scenario 3

45. Graphs showing annual groundwater budgets, 2051-60, simulated by base scenario and scenario 3; annual loss in flow in the Carson River 2051-60 predicted by base scenario and scenario 3

\section{Tables}

1. USGS and FWM gaging stations on the Carson River and selected tributaries and diversion ditches

2. Summary of aquifer tests in Carson Valley

3. Mean annual water budget for Carson Valley for water years 1990 through 2005 ............... 27

4. Components of the groundwater budget for Carson Valley .................................................... 28

5. Groups of stream segments for which streambed hydraulic conductivity was specified ... 35

6. Groups of observations included in model calibration: heads ; flows 38

7. Parameter values in Carson Valley groundwater model specified or estimated through nonlinear regression

8. Simulated mean-annual groundwater budget for Carson Valley from water year 1971 through 2005

9. Simulated annual water budgets for Carson Valley in the 1992 and 1997 water years......... 54

10. Future water-use scenarios represented in 55 -year predictive simulations 


\section{Conversion Factors and Datums}

\begin{tabular}{|c|c|c|}
\hline Multiply & By & To obtain \\
\hline \multicolumn{3}{|c|}{ Length } \\
\hline inch (in) & 2.54 & centimeter $(\mathrm{cm})$ \\
\hline inch (in) & 25.4 & millimeter (mm) \\
\hline foot $(\mathrm{ft})$ & 0.3048 & meter $(\mathrm{m})$ \\
\hline mile (mi) & 1.609 & kilometer $(\mathrm{km})$ \\
\hline \multicolumn{3}{|c|}{ Area } \\
\hline acre & 4,047 & square meter $\left(\mathrm{m}^{2}\right)$ \\
\hline acre & 0.4047 & hectare (ha) \\
\hline acre & 0.4047 & square hectometer $\left(\mathrm{hm}^{2}\right)$ \\
\hline acre & 0.004047 & square kilometer $\left(\mathrm{km}^{2}\right)$ \\
\hline square foot $\left(\mathrm{ft}^{2}\right)$ & 929.0 & square centimeter $\left(\mathrm{cm}^{2}\right)$ \\
\hline square foot $\left(\mathrm{ft}^{2}\right)$ & 0.09290 & square meter $\left(\mathrm{m}^{2}\right)$ \\
\hline square mile $\left(\mathrm{mi}^{2}\right)$ & 259.0 & hectare (ha) \\
\hline square mile $\left(\mathrm{mi}^{2}\right)$ & 2.590 & square kilometer $\left(\mathrm{km}^{2}\right)$ \\
\hline \multicolumn{3}{|c|}{ Volume } \\
\hline gallon (gal) & 3.785 & liter $(\mathrm{L})$ \\
\hline gallon (gal) & 0.003785 & cubic meter $\left(\mathrm{m}^{3}\right)$ \\
\hline gallon (gal) & 3.785 & cubic decimeter $\left(\mathrm{dm}^{3}\right)$ \\
\hline million gallons (Mgal) & 3,785 & cubic meter $\left(\mathrm{m}^{3}\right)$ \\
\hline cubic foot $\left(\mathrm{ft}^{3}\right)$ & 28.32 & cubic decimeter $\left(\mathrm{dm}^{3}\right)$ \\
\hline cubic foot $\left(\mathrm{ft}^{3}\right)$ & 0.02832 & cubic meter $\left(\mathrm{m}^{3}\right)$ \\
\hline acre-foot (acre-ft) & 1,233 & cubic meter $\left(\mathrm{m}^{3}\right)$ \\
\hline acre-foot (acre-ft) & 0.001233 & cubic hectometer $\left(\mathrm{hm}^{3}\right)$ \\
\hline \multicolumn{3}{|c|}{ Flow rate } \\
\hline acre-foot per day (acre-ft/d) & 0.01427 & cubic meter per second $\left(\mathrm{m}^{3} / \mathrm{s}\right)$ \\
\hline acre-foot per year (acre-ft/yr) & 1,233 & cubic meter per year $\left(\mathrm{m}^{3} / \mathrm{yr}\right)$ \\
\hline acre-foot per year (acre-ft/yr) & 0.001233 & cubic hectometer per year $\left(\mathrm{hm}^{3} / \mathrm{yr}\right)$ \\
\hline foot per second $(\mathrm{ft} / \mathrm{s})$ & 0.3048 & meter per second $(\mathrm{m} / \mathrm{s})$ \\
\hline foot per minute ( $\mathrm{ft} / \mathrm{min})$ & 0.3048 & meter per minute $(\mathrm{m} / \mathrm{min})$ \\
\hline foot per day $(\mathrm{ft} / \mathrm{d})$ & 0.3048 & meter per day $(\mathrm{m} / \mathrm{d})$ \\
\hline foot per year $(\mathrm{ft} / \mathrm{yr})$ & 0.3048 & meter per year $(\mathrm{m} / \mathrm{yr})$ \\
\hline cubic foot per second $\left(\mathrm{ft}^{3} / \mathrm{s}\right)$ & 0.02832 & cubic meter per second $\left(\mathrm{m}^{3} / \mathrm{s}\right)$ \\
\hline $\begin{array}{l}\text { cubic foot per second per square } \\
\text { mile }\left[\left(\mathrm{ft}^{3} / \mathrm{s}\right) / \mathrm{mi}^{2}\right]\end{array}$ & 0.01093 & $\begin{array}{l}\text { cubic meter per second per square } \\
\text { kilometer }\left[\left(\mathrm{m}^{3} / \mathrm{s}\right) / \mathrm{km}^{2}\right]\end{array}$ \\
\hline cubic foot per day $\left(\mathrm{ft}^{3} / \mathrm{d}\right)$ & 0.02832 & cubic meter per day $\left(\mathrm{m}^{3} / \mathrm{d}\right)$ \\
\hline gallon per minute (gal/min) & 0.06309 & liter per second $(\mathrm{L} / \mathrm{s})$ \\
\hline gallon per day (gal/d) & 0.003785 & cubic meter per day $\left(\mathrm{m}^{3} / \mathrm{d}\right)$ \\
\hline million gallons per day $(\mathrm{Mgal} / \mathrm{d})$ & 0.04381 & cubic meter per second $\left(\mathrm{m}^{3} / \mathrm{s}\right)$ \\
\hline mile per hour $(\mathrm{mi} / \mathrm{h})$ & 1.609 & kilometer per hour $(\mathrm{km} / \mathrm{h})$ \\
\hline \multicolumn{3}{|c|}{ Specific capacity } \\
\hline $\begin{array}{l}\text { gallon per minute per foot } \\
[(\mathrm{gal} / \mathrm{min}) / \mathrm{ft})]\end{array}$ & 0.2070 & liter per second per meter $[(\mathrm{L} / \mathrm{s}) / \mathrm{m}]$ \\
\hline \multicolumn{3}{|c|}{ Hydraulic conductivity } \\
\hline foot per day (ft/d) & 0.3048 & meter per day $(\mathrm{m} / \mathrm{d})$ \\
\hline \multicolumn{3}{|c|}{ Hydraulic gradient } \\
\hline foot per mile $(\mathrm{ft} / \mathrm{mi})$ & 0.1894 & meter per kilometer $(\mathrm{m} / \mathrm{km})$ \\
\hline \multicolumn{3}{|c|}{ Transmissivity* } \\
\hline foot squared per day $\left(\mathrm{ft}^{2} / \mathrm{d}\right)$ & 0.09290 & meter squared per day $\left(\mathrm{m}^{2} / \mathrm{d}\right)$ \\
\hline \multicolumn{3}{|c|}{ Application rate } \\
\hline $\begin{array}{l}\text { pounds per acre per year } \\
{[(\mathrm{lb} / \mathrm{acre}) / \mathrm{yr}]}\end{array}$ & 1.121 & $\begin{array}{l}\text { kilograms per hectare per year } \\
{[(\mathrm{kg} / \mathrm{ha}) / \mathrm{yr}]}\end{array}$ \\
\hline \multicolumn{3}{|c|}{ Leakance } \\
\hline foot per day per foot $[(\mathrm{ft} / \mathrm{d}) / \mathrm{ft}]$ & 1 & meter per day per meter \\
\hline inch per year per foot $[(\mathrm{in} / \mathrm{yr}) / \mathrm{ft}]$ & 83.33 & $\begin{array}{l}\text { millimeter per year per meter } \\
{[(\mathrm{mm} / \mathrm{yr}) / \mathrm{m}]}\end{array}$ \\
\hline
\end{tabular}

Temperature in degrees Fahrenheit $\left({ }^{\circ} \mathrm{F}\right)$ may be converted to degrees Celsius $\left({ }^{\circ} \mathrm{C}\right)$ as follows:

${ }^{\circ} \mathrm{C}=\left({ }^{\circ} \mathrm{F}-32\right) / 1.8$ 
Vertical coordinate information is referenced to the North American Vertical Datum of 1988 (NAVD 88).

Horizontal coordinate information is referenced to the North American Datum of 1983 (NAD 83). Altitude, as used in this report, refers to distance above the vertical datum.

*Transmissivity: The standard unit for transmissivity is cubic foot per day per square foot times foot of aquifer thickness [(ft $\left.\left.\mathrm{ft}^{3} / \mathrm{d}\right) / \mathrm{ft}^{2}\right] \mathrm{ft}$. In this report, the mathematically reduced form, foot squared per day $\left(\mathrm{ft}^{2} / \mathrm{d}\right)$, is used for convenience. 


\section{Acknowledgments}

The authors thank Mimi Moss of Douglas County Community Development, Planning Division, Ron Roman and Carl Ruschmeyer of Douglas County Public Works, and Edwin James of the Carson Water Subconservancy District for providing information and assistance in developing the predictive simulations. Rob Anderson of RO Anderson Engineering, Michael Bennett of Lumos and Associates, Inc., Dale Bugenig of EcoLogic, Mark Gonzales of the Gardnerville Water Co., Carl Rushmeyer of Douglas County Public Works, Bruce Scott of Resource Concepts, Inc., and Bob Spellberg of the Gardnerville Ranchos General Improvement District who provided aquifer-test data that were used in this report. Donald Callahan, Julian Larrouy, Gary Stone, and Dave Wathen of the Federal Water Master's Office provided data and information on irrigation diversions and historical irrigation practices. Scott Clark, Tony Eng, and Steve Walmsley of the Nevada Department of Water Resources provided data and information on the distribution of groundwater pumping in Carson Valley and areas irrigated with perennial streams of the Carson Range. 


\title{
Assessing Potential Effects of Changes in Water Use With a Numerical Groundwater-Flow Model of Carson Valley, Douglas County, Nevada, and Alpine County, California
}

\author{
By Richard M. Yager, Douglas K. Maurer and C.J. Mayers
}

\section{Abstract}

Rapid growth and development within Carson Valley in Douglas County, Nevada, and Alpine County, California, has caused concern over the continued availability of groundwater, and whether the increased municipal demand could either impact the availability of water or result in decreased flow in the Carson River. Annual pumpage of groundwater has increased from less than 10,000 acre feet per year (acre-ft/yr) in the 1970s to about 31,000 acre-ft/yr in 2004, with most of the water used in agriculture. Municipal use of groundwater totaled about 10,000 acre-feet in 2000. In comparison, average streamflow entering the valley from 1940 to 2006 was 344,100 acre-ft/yr, while average flow exiting the valley was 297,400 acre-ft/yr.

Carson Valley is underlain by semi-consolidated Tertiary sediments that are exposed on the eastern side and dip westward. Quaternary fluvial and alluvial deposits overlie the Tertiary sediments in the center and western side of the valley. The hydrology of Carson Valley is dominated by the Carson River, which supplies irrigation water for about 39,000 acres of farmland and maintains the water table less than 5 feet (ft) beneath much of the valley floor. Perennial and ephemeral watersheds drain the Carson Range and the Pine Nut Mountains, and mountain-front recharge to the groundwater system from these watersheds is estimated to average 36,000 acre-ft/yr.

Groundwater in Carson Valley flows toward the Carson River and north toward the outlet of the Carson Valley. An upward hydraulic gradient exists over much of the valley, and artesian wells flow at land surface in some areas. Water levels declined as much as $15 \mathrm{ft}$ since 1980 in some areas on the eastern side of the valley. Median estimated transmissivities of Quaternary alluvial-fan and fluvial sediments, and Tertiary sediments are 316; 3,120; and 110 feet squared per day $\left(\mathrm{ft}^{2} / \mathrm{d}\right)$, respectively, with larger transmissivity values in the central part of the valley and smaller values near the valley margins.

A groundwater-flow model of Quaternary and Tertiary sediments in Carson Valley was developed using MODFLOW and calibrated to simulate historical conditions from water years 1971 through 2005. The 35-year transient simulation represented quarterly changes in precipitation, streamflow, pumping and irrigation. Inflows to the groundwater system simulated in the model include mountain-front recharge from watersheds in the Carson Range and Pine Nut Mountains, valley recharge from precipitation and land application of wastewater, agricultural recharge from irrigation, and septic-tank discharge. Outflows from the groundwater system simulated in the model include evapotranspiration from the water table and groundwater withdrawals for municipal, domestic, irrigation and other water supplies. The exchange of water between groundwater, the Carson River, and the irrigation system was represented with a version of the Streamflow Routing (SFR) package that was modified to apply diversions from the irrigation network to irrigated areas as recharge.

The groundwater-flow model was calibrated through nonlinear regression with UCODE to measured water levels and streamflow to estimate values of hydraulic conductivity, recharge and streambed hydraulic-conductivity that were represented by 18 optimized parameters. The aquifer system was simulated as confined to facilitate numerical convergence, and the hydraulic conductivity of the top active model layers that intersect the water table was multiplied by a factor to account for partial saturation. Storage values representative of specific yield were specified in parts of model layers where unconfined conditions are assumed to occur. The median transmissivity (T) values $\left(11,000\right.$ and $800 \mathrm{ft}^{2} / \mathrm{d}$ for the fluvial and alluvial-fan sediments, respectively) are both within the third quartile of $T$ values estimated from specific-capacity data, but $T$ values for Tertiary sediments are larger than the third quartile estimated from specific-capacity data. The estimated vertical anisotropy for the Quaternary fluvial sediments $(9,000)$ is comparable to the value estimated for a previous model of Carson Valley. The estimated total volume of mountain-front recharge is equivalent to a previous estimate from the Precipitation-Runoff Modeling System (PRMS) watershed models, but less recharge is estimated for the Carson Range and more recharge is estimated for the Pine Nut Mountains than the previous estimate.

Simulated flow paths indicate that groundwater flows faster through the center of Carson Valley and slower through the lower hydraulic-conductivity Tertiary sediments to the east. Shallow flow in the center of the valley is towards drainage 
channels, but deeper flow is generally directed toward the basin outlet to the north. The aquifer system is in a dynamic equilibrium with large inflows from storage in dry years and large outflows to storage in wet years. Pumping has historically been less than 10 percent of outflows from the groundwater system, and agricultural recharge has been less than 10 percent of inflows to the groundwater system. Three principal sources of uncertainty that affect model results are: (1) the hydraulic characteristics of the Tertiary sediments on the eastern side of the basin, (2) the composition of sediments beneath the alluvial fans and (3) the extent of the confining unit represented within fluvial sediments in the center of the basin.

The groundwater-flow model was used in five 55-year predictive simulations to evaluate the long-term effects of different water-use scenarios on water-budget components, groundwater levels, and streamflow in the Carson River. The predictive simulations represented water years 2006 through 2060 using quarterly stress periods with boundary conditions that varied cyclically to represent the transition from wet to dry conditions observed from water years 1995 through 2004. The five scenarios included a base scenario with 2005 pumping rates held constant throughout the simulation period and four other scenarios using: (1) pumping rates increased by 70 percent, including an additional 1,340 domestic wells, (2A) pumping rates more than doubled with municipal pumping increased by a factor of four over the base scenario, (2B) pumping rates of $2 \mathrm{~A}$ with 2,040 fewer domestic wells, and (3) pumping rates of $2 \mathrm{~A}$ with 3,700 acres removed from irrigation. The 55-year predictive simulations indicate that increasing groundwater withdrawals under the scenarios considered would result in as much as $40 \mathrm{ft}$ and $60 \mathrm{ft}$ of water-table decline on the west and east sides of Carson Valley, respectively. The water table in the central part of the valley would remain essentially unchanged, but water-level declines of as much as $30 \mathrm{ft}$ are predicted for the deeper, confined aquifer. The increased withdrawals would reduce the volume of groundwater storage and decrease the mean downstream flow in the Carson River by as much as 16,500 acre-ft/yr. If, in addition, 3,700 acres were removed from irrigation, the reduction in mean downstream flow in the Carson River would be only 6,500 acre-ft/yr. The actual amount of flow reduction is uncertain because of potential changes in irrigation practices that may not be accounted for in the model. The projections of the predictive simulations are sensitive to rates of mountainfront recharge specified for the Carson Range and the Pine Nut Mountains. The model provides a tool that can be used to aid water managers and planners in making informed decisions. A prudent management approach would include continued monitoring of water levels on both the east and west sides of Carson Valley to either verify the predictions of the groundwater-flow model or to provide additional data for recalibration of the model if the predictions prove inaccurate.

\section{Introduction}

Rapid population growth and suburban development in Carson Valley, west-central Nevada (fig. 1), is causing concern over the continued availability of water resources in the future. The increased demand for groundwater for municipal use within the valley could impact the availability of water. In addition, the increased municipal demand for groundwater could also reduce discharge to the Carson River and, in turn, impact downstream water users that depend on sustained river flow. A numerical groundwater-flow model that simulates the exchange of water between the aquifer and surface water in Carson Valley was developed to evaluate the impacts of a range of future groundwater management alternatives. The model provides a tool that can be used to aid water managers and planners in making informed decisions.

The potential effects of groundwater withdrawals on flow in the Carson River have previously been estimated using a groundwater-flow model developed for Carson Valley in the early 1980s (Maurer, 1986; Prudic and Wood, 1995). Prior model simulations indicated that flow in the Carson River was the source of 70 to 80 percent of groundwater pumped in Carson Valley (Maurer, 1986, p. 105; Prudic and Wood, 1995, p. 28). These model simulations also indicated that the reduction of irrigated lands resulted in increased flow in the Carson River that could offset the effects of pumping (Maurer, 1986, p. 90). These results were considered preliminary, however, because the volume of pumping during the model-calibration period (1981-83) was less than 5 percent of the total water budget, the period of model calibration was short, and the grid cells used in the model were relatively large ( 1 square mile; Maurer, 1986, p. 82).

\section{Previous studies}

In February 2003, the U.S. Geological Survey (USGS) began a study in cooperation with Douglas County, Nevada, and the Carson Water Subconservancy District to improve estimates of water-budget components in Carson Valley in order to address concerns over continued residential growth. As part of the study, five reports have been published. The first two developed improved estimates of the distribution of precipitation in Carson Valley (Maurer and Halford, 2004) and flow in perennial streams tributary to the Carson Valley (Maurer and others, 2004). The third report provided estimates of (1) evapotranspiration (ET) from various types of vegetation and land use, (2) recharge from precipitation on the northern and eastern parts of Carson Valley, and (3) the location and rates of streamflow losses and gains from streams and irrigation ditches on the valley floor (Maurer and others, 2006). The fourth report presented estimates of water-budget components for Carson Valley and presented preliminary estimates of the potential effects of changes in water use (Maurer and Berger, 2007). The fifth report used the Precipitation-Runoff Modeling System (PRMS; Leavesly, 1983) watershed models of the 


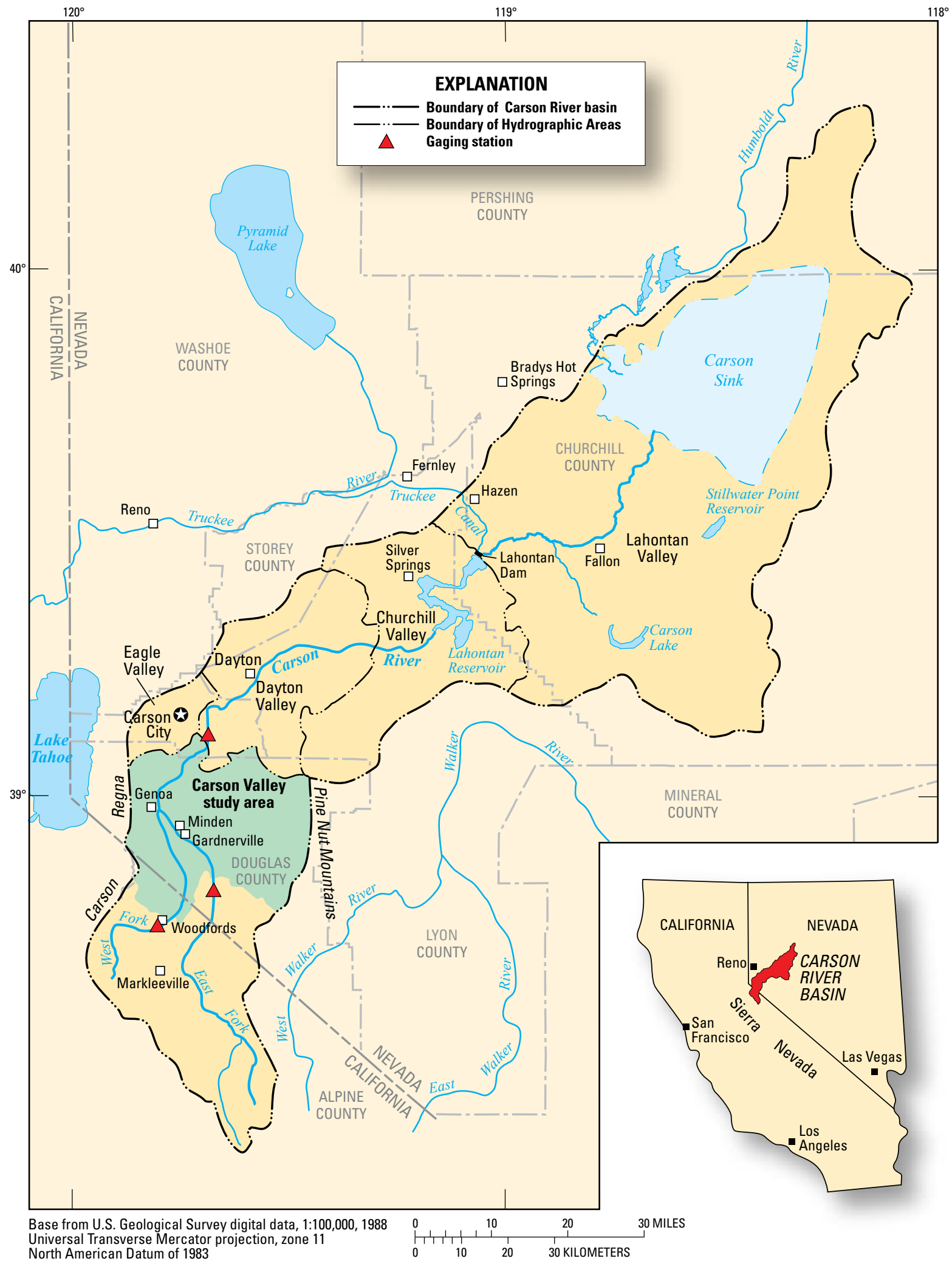

Figure 1. Location of the Carson River basin and the Carson Valley study area. 
Carson Range and Pine Nut Mountains to estimate groundwater recharge and ephemeral streamflow from the mountains surrounding the valley (Jeton and Maurer, 2007).

The final phase of work included a refinement of the groundwater-flow model for Carson Valley. Previous reports had cited the need for a more detailed groundwater-flow model to better estimate the discharge of water through evapotranspiration by native plants and irrigated crops, and the volumes of water exchanged between the groundwater and surface water systems in Carson Valley (Maurer and Berger, 2007, p. 44, $55,56)$. The model developed for the study described herein provides estimates of the groundwater-budget components for Carson Valley and was used to evaluate the potential effects of changes in water use on groundwater levels in Carson Valley and on flow in the Carson River exiting Carson Valley.

\section{Purpose and Scope}

The purpose of this report is to describe the development, calibration, and application of the groundwater-flow model for Carson Valley. The report presents a discussion of the hydrogeologic setting of Carson Valley, including a description of the geology, estimates of streamflow, groundwater withdrawals and aquifer properties, and a description of the groundwater-flow system. The report also presents results of five predictive simulations for water years ${ }^{1} 2006-60$ made with the calibrated model to estimate the potential effects of changes in water use. The predictive simulations included a base simulation in which water use remained unchanged from 2005 conditions; two simulations that increased municipal pumping from 9,000 acre-feet per year (acre-ft/yr) to 22,000 and 33,000 acre-ft/yr, respectively; a fourth simulation in which the higher municipal pumping rate was concentrated in several municipal wells rather than dispersed through many domestic wells; and a final simulation in which the higher municipal-pumping rate was combined with a removal of about 3,700 acres of land from irrigation.

\section{Geographic Setting}

Carson Valley is mainly in Douglas County, south of Carson City, Nevada's capital (fig. 1). The southern end of the valley extends about 3 miles (mi) into Alpine County, California. The floor of the valley is oval-shaped, about 20-mi long and 8-mi wide, and slopes from about 5,000 feet (ft) above sea level at the southern end to about 4,600 ft at the northern end. On the western side of Carson Valley the Carson Range of the Sierra Nevada rises abruptly from the valley floor with peaks ranging from 9,000 to $11,000 \mathrm{ft}$ in altitude; on the eastern side, the Pine Nut Mountains rise more gradually to peaks ranging from 8,000 to $9,000 \mathrm{ft}$.

\footnotetext{
${ }^{1} \mathrm{~A}$ water year extends from October through the following September and is designated in the calendar year in which it ends.
}

For purposes of this study, the boundary of Carson Valley was delineated as a 396-square mile $\left(\mathrm{mi}^{2} ; 253,570\right.$-acre) subarea within the Carson Valley Hydrographic Area, which extends to the headwaters of the East and West Forks of the Carson River (fig. 1). The model domain was selected to include only unconsolidated and semi-consolidated sediments that transmit most of the groundwater in the aquifer system that underlies the Carson Valley. The headwaters of the West and East Forks of the Carson River upstream of gaging stations are outside the model domain. Bedrock underlies the points where the West and East Forks of the Carson River cross the domain boundary, however, restricting groundwater inflow from areas to the south.

On the western side of the valley, sagebrush and bitterbrush cover steep alluvial fans, and manzanita and ponderosa pine trees cover the slopes of the Carson Range (fig. 2).

Alluvial fans and foothills of the Pine Nut Mountains on the eastern side of the valley are covered with sagebrush and rabbitbrush, but pinyon and juniper trees occur at higher altitudes. The valley floor corresponds to the area covered with pasture grasses and crop lands (mainly alfalfa), and native phreatophytes (plants whose roots tap the water table). Greasewood, rabbitbrush, and big sage occupy the northern end of the valley floor, and riparian willows and cottonwood trees line the Carson River and many irrigation ditches. A land-use map by Maurer and Berger (2007, p. 7) was used as the basis for the specification of evapotranspiration rates (the consumptive use of water by pasture grasses, crops, and phreatophytes) and rates of groundwater recharge and discharge from various types of land use in the model developed for this study.

Carson Valley lies in the rain shadow of the Sierra Nevada, and annual precipitation decreases greatly eastward from the crest of the mountains to the valley floor. Annual precipitation at the town of Minden (fig. 3) averages 8.4 inches (in.) for the period 1971-2000 (National Oceanic and Atmospheric Administration, 2002, p. 12). In contrast, the crest of the Carson Range receives about 40 inches per year (in/yr), and the crest of the Pine Nut Mountains receives from 15 to $18 \mathrm{in} / \mathrm{yr}$ (Maurer and Halford, 2004, p. 35). From 1984 to 1992 and from 1999 to 2004, conditions were drier than normal with annual precipitation considerably less than average (fig. $3 \mathrm{~A}$ ). The Palmer Drought Severity Index (PDSI, National Oceanic and Atmospheric Administration, 2006), based on long-term weather conditions, provides an indication of regional meteorological wet and dry periods (fig. $3 B$ ). The PDSI indicates dry conditions have dominated western Nevada since about 1999.

Douglas County has grown from a population of about 28,000 in 1990 to 46,000 in 2006, an increase of 66 percent (Economic Research Service, 2007). The major towns in Carson Valley are Minden, Gardnerville, and Genoa; however, much of the increased growth has taken place in outlying subdivisions. The major subdivisions include the Gardnerville Ranchos and Ruhenstroth south of Gardnerville, Fish Spring Flat east of Gardnerville, and Johnson Lane and Indian Hills north of Minden (fig. 4). In addition, residential development has spread along the eastern and western margins of the valley 


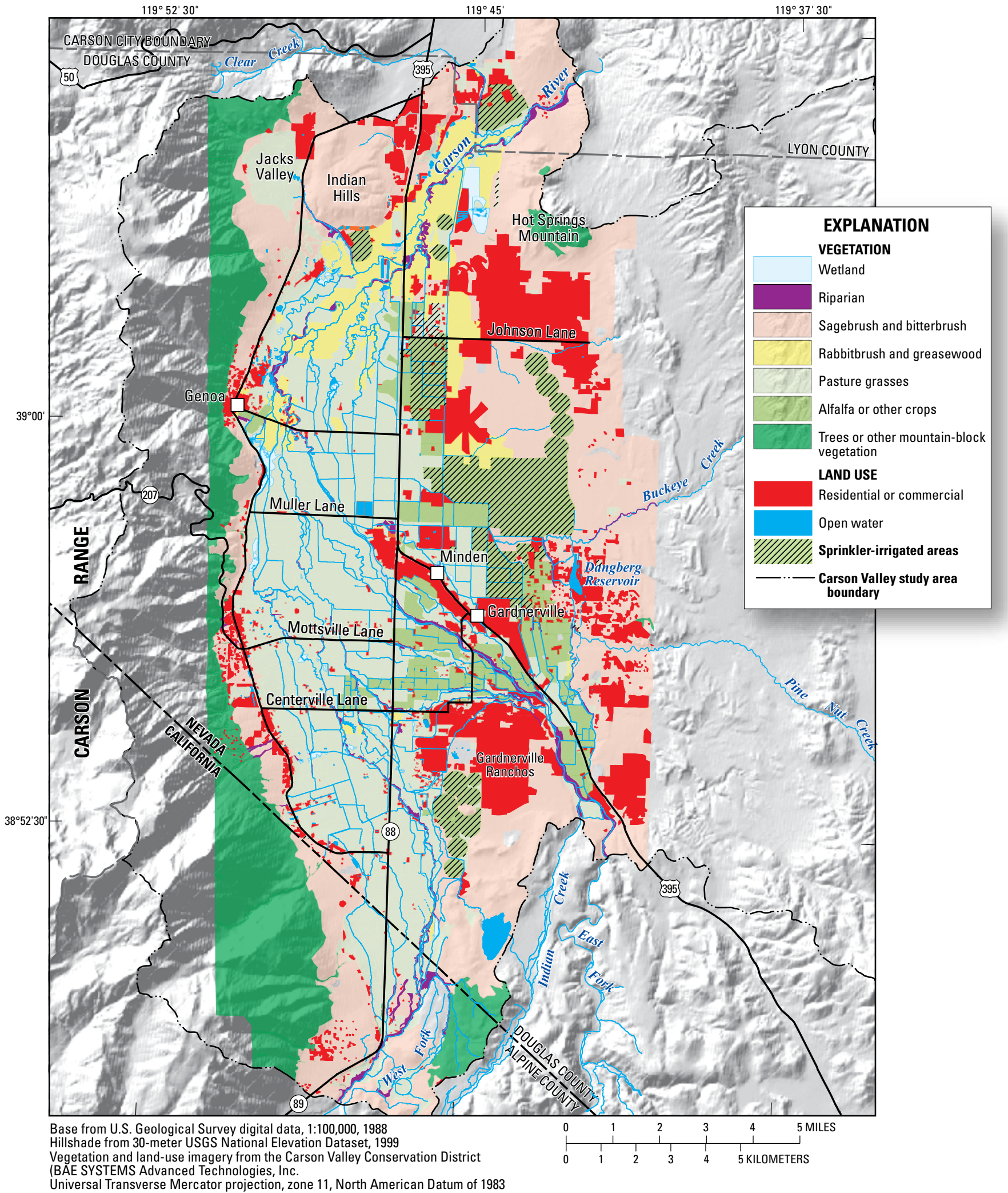

Figure 2. Vegetation and land use in and near Carson Valley, 2005. 

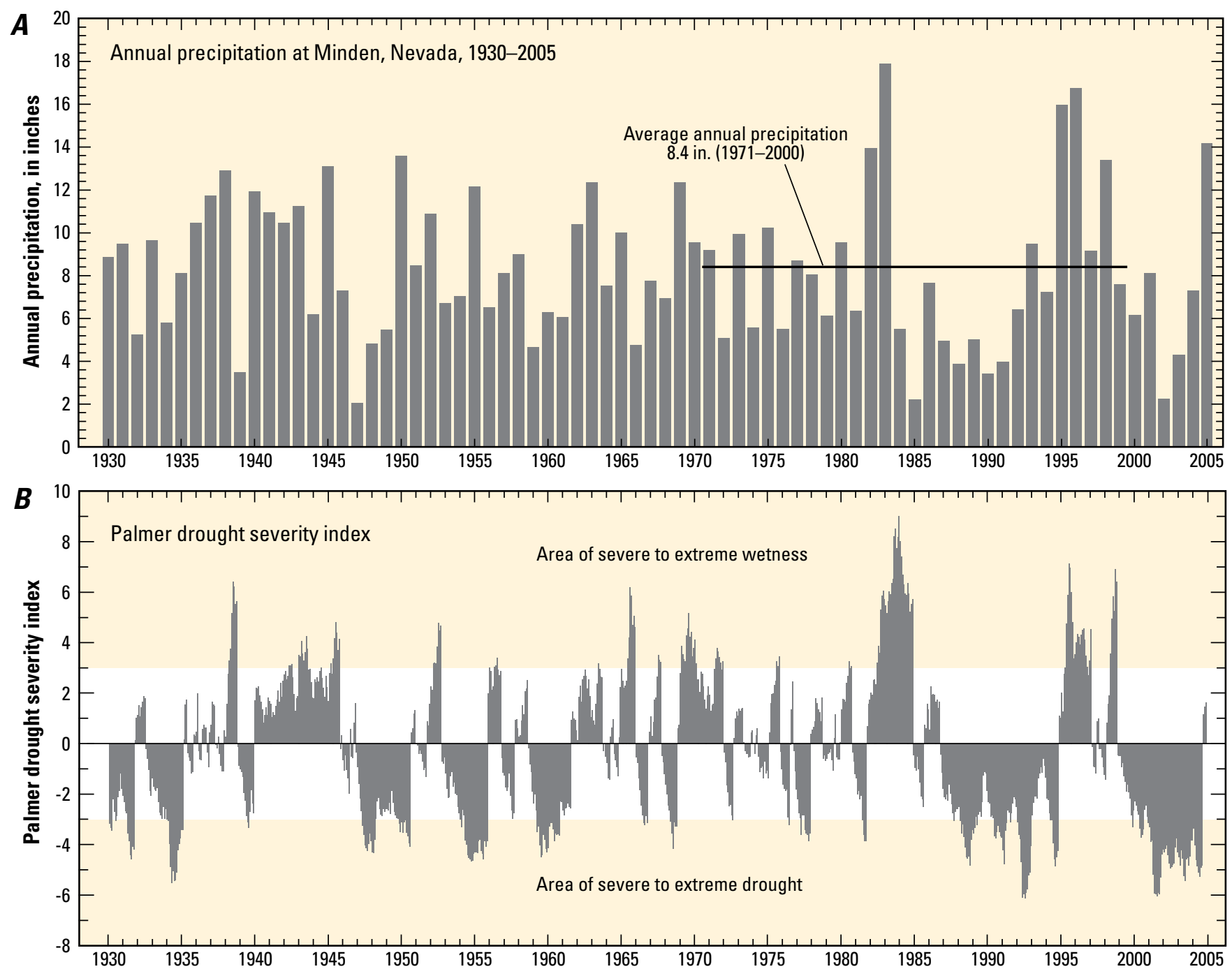

Figure 3. A, Annual precipitation at Minden, Nevada, for period of record (1930-2005) and average annual precipitation for 1971-2000; $B$, Palmer Drought Severity Index for western Nevada, 1930-2005.

floor, and into scattered locations throughout the valley floor on land that historically has been agricultural.

\section{Geologic Setting}

Geologic units that were delineated in Carson Valley by Maurer and Berger (2007, p. 9) based on the map of Stewart and Carlson (1978) were modified for the design of the groundwater-flow model in this study (fig. 5). Granitic, metamorphic, and volcanic rocks of Jurassic to Tertiary age that form the mountain blocks surrounding the valley floor were grouped into a single consolidated rock unit. These consolidated rocks are overlain by Tertiary sediments and Quaternary alluvial fans and fluvial sediments. Maurer and Berger (2007, p. 9) delineated Quaternary gravel deposits capping the Indian Hills in the northwestern part of the valley and Quaternary eolian sand deposits in the northeastern part of the valley. In this study the relatively thin Quaternary gravel deposits capping the Indian Hills (Stewart, 1999, p. 2) were grouped with Tertiary sediments. The Quaternary eolian sand deposits are also likely thin veneers in the northeastern part of the valley and so were grouped with the underlying alluvial-fan deposits.

Basin and range faulting during the Tertiary Period from 7 to 10 million years ago produced the present topography in Carson Valley (Muntean, 2001, p. 9). Faulting uplifted the Carson Range and the Pine Nut Mountains and downdropped consolidated rock beneath the floor of Carson Valley. Volcanic rocks and sediments deposited contemporaneous with this faulting have since become semi-consolidated. These semi-consolidated Tertiary sediments are exposed mainly on the eastern side of the valley, but dip towards the west and probably underlie the entire valley (figs. 5, 6). The Tertiary sediments vary in degree of compaction and lithology (Pease, 1980, p. 14), varying from fine-grained and tuffaceous siltstone with isolated lenses of sandstone and conglomerate to sandstone and conglomerate (Muntean, 2001, p. 18-31). 


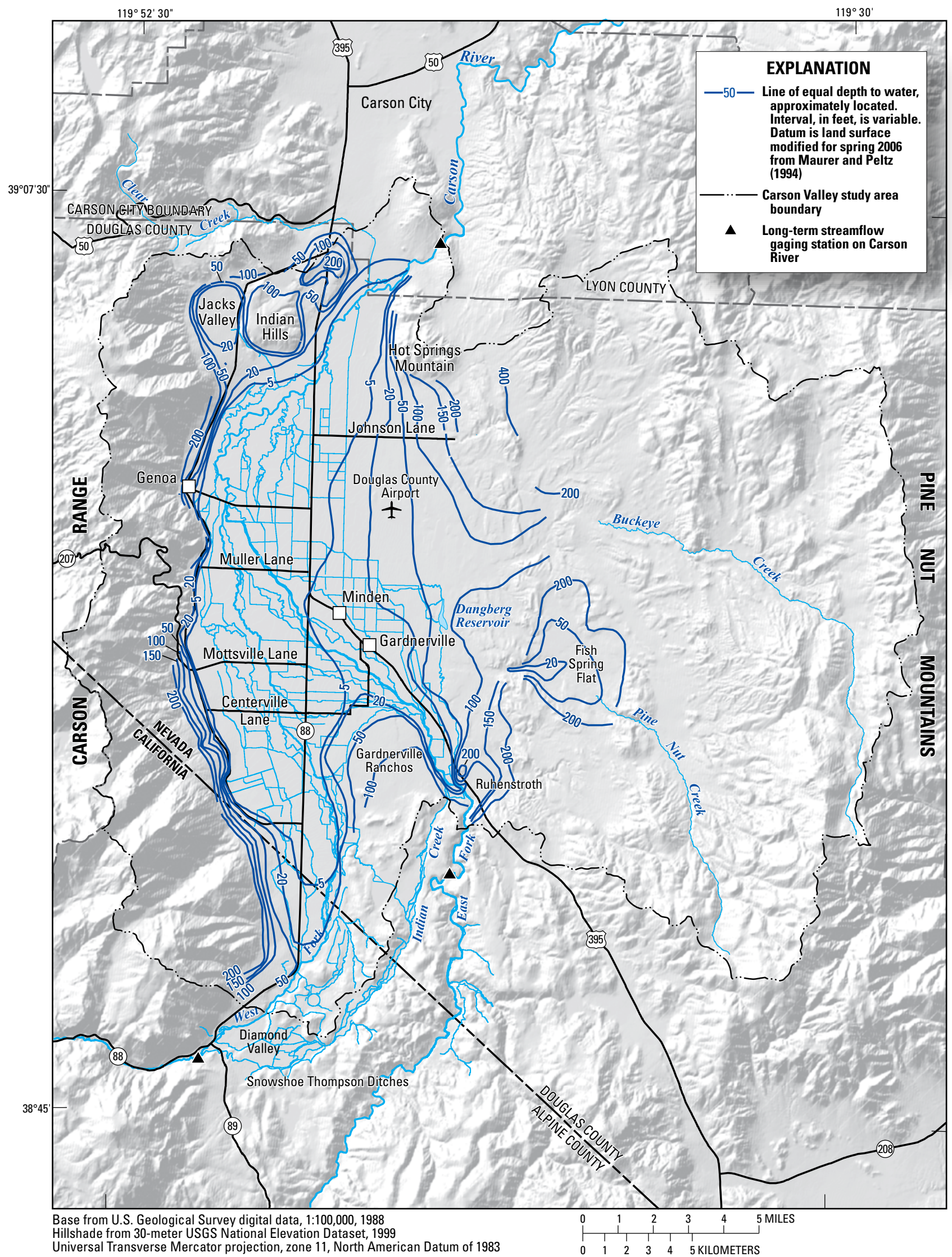

Figure 4. Locations of towns and approximate depth to water (spring 2006) in Carson Valley. 


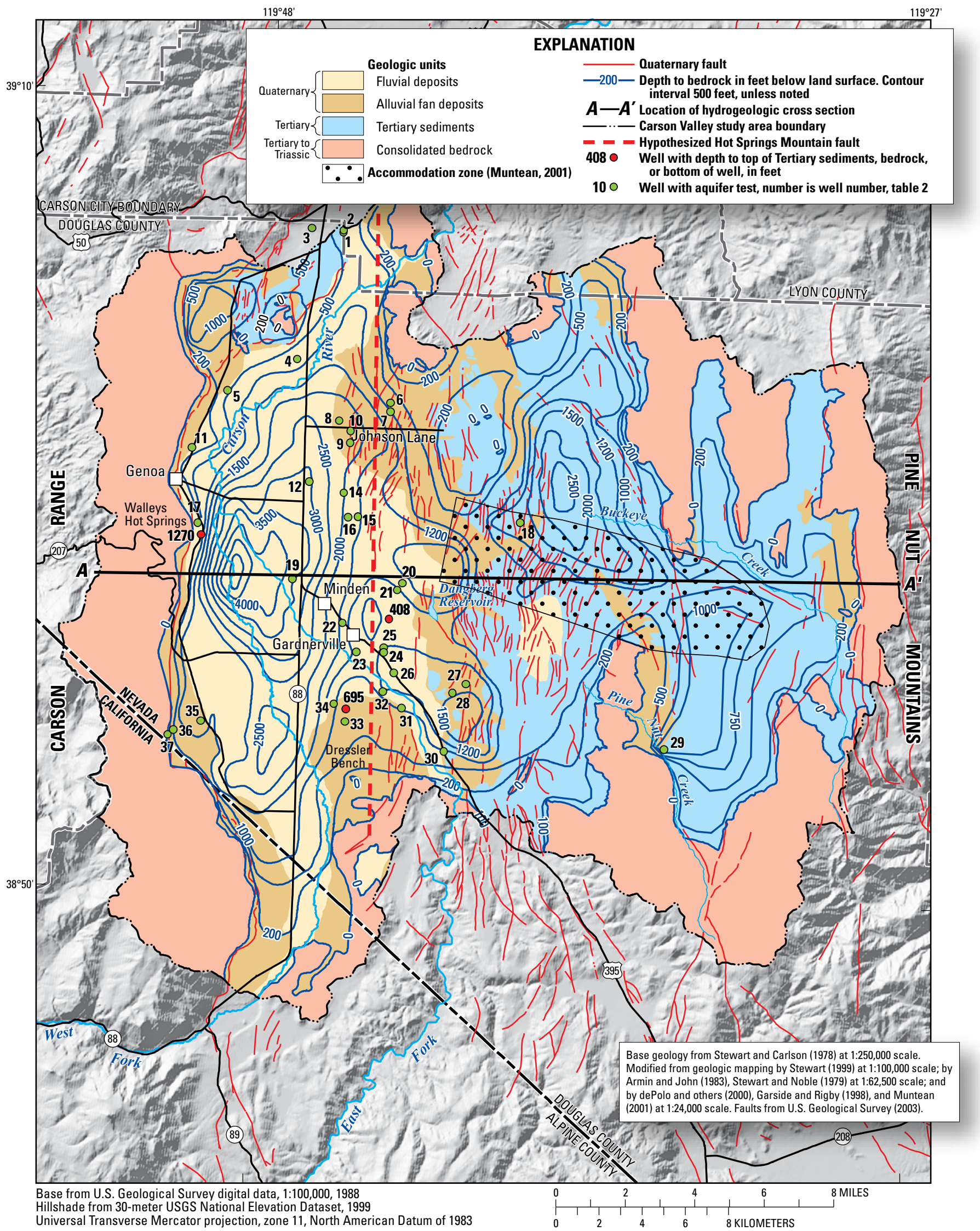

Figure 5. Geologic units, depth to bedrock, faults, and locations of aquifer tests; selected wells likely penetrating Tertiary sediments; and east-west hydrogeologic cross section. 


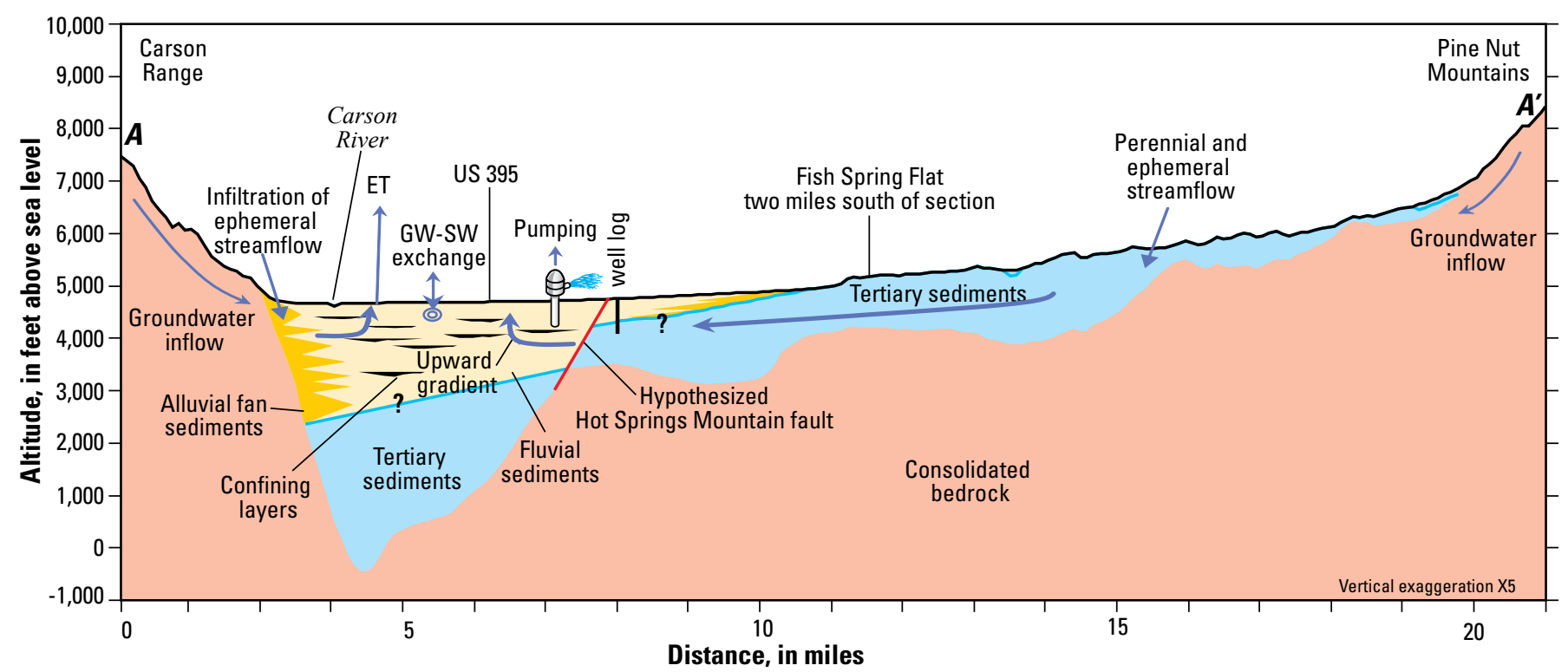

Figure 6. Hydrogeologic cross-section $A-A^{\prime}$ and conceptual model of groundwater flow paths in Carson Valley.

Muntean (p. 35) divided the Tertiary sediments into subsections on the basis of age and provided a detailed description of the stratigraphy of the Tertiary sediments in each subsection. The aggregate thickness of the Tertiary sediments is estimated to exceed 3,000 ft (Muntean, pl. 5).

Throughout the Quaternary Period (within the past 2 million years), unconsolidated sediments, herein referred to as basin fill, have been deposited by the Carson River and tributary streams from the Carson Range and the Pine Nut Mountains. The Quaternary sediments deposited by tributary streams form coalescing alluvial fans that consist of coarseto fine-grained, poorly sorted mixtures of sand, gravel, silt, and clay at the base of the mountains (fig. 5). The Quaternary deposits of the Carson River are fluvial sediments that consist of well-sorted sand and gravel, interbedded with fine-grained silt and clay from over-bank flood deposits. These fluvial sediments underlie most of the valley floor. The alluvial-fan and fluvial sediments likely interfinger beneath the margins of the valley, but detailed information is not available on the distribution of these sediments with depth. The Dressler Bench, mapped as an alluvial-fan deposit at the southern end of the valley between the East and West Forks of the Carson River, is actually a river terrace consisting of boulders, cobbles, and gravel (Dillingham, 1980, p. 18; dePolo and others, 2000).

The mountains bounding Carson Valley are west-tilted structural blocks (Stewart, 1980, p. 113), and Carson Valley overlies the down-dropped western part of the Pine Nut Mountain block (Moore, 1969, p. 18). Continued westward tilting of the blocks is indicated by recent faulting along the base of the Carson Range (Pease, 1980, p. 15) and by displacement of the Carson River to the extreme western side of the valley (Moore, 1969, p. 18). A steep, well-defined normal fault has created a 5,000-ft escarpment along the eastern side of the Carson Range, but a wider zone of faulting consisting of numerous faults is present on the eastern side of the valley (fig. 5). Muntean (2001) describes an accommodation zone on the eastern side of the valley where the vertical offset of faults north and south of the zone decreases toward the zone. A continuous section of tilted Tertiary sedimentary deposits is present within the accommodation zone. The zone is thought to be related to the location of maximum displacement on the fault bounding the western side of Carson Valley, directly to the west across the valley (Muntean, 2001, p. 80).

A gravity survey by Maurer (1984) estimated the depth to bedrock underlying the Quaternary and Tertiary sediments in Carson Valley. The gravity data indicate a deep basin beneath the western part of the valley, as much as 5,000 ft below land surface about $1.5 \mathrm{mi}$ southeast of Wallys Hot Springs (fig. 5). The basin rapidly decreases in depth eastward from about $3,500 \mathrm{ft}$ below land surface near US 395 to $1,500 \mathrm{ft}$ below land surface about $2 \mathrm{mi}$ east of the highway. The rapid change in depth extends from the western side of Hot Springs Mountain on the north through a ridge on the bedrock surface $1 \mathrm{mi}$ east of Minden (fig. 5). The steep eastern side of the bedrock valley corresponds to the western extent of Quaternary faults and suggests the presence of a major buried fault. This hypothesized fault is informally called the Hot Springs Mountain fault in this report. Bedrock is relatively shallow east of the Hot Springs Mountain fault; depth to bedrock ranges from less than $200 \mathrm{ft}$ east of Johnson Lane to as much as $1,000 \mathrm{ft}$ north of Fish Spring Flat. Further east, structural basins beneath the northeast and southeast sides of the valley have estimated depths as great as $2,500 \mathrm{ft}$ and $1,000 \mathrm{ft}$ below land surface, respectively.

Sediments that overlie bedrock on the western side of the valley consist of both Quaternary and Tertiary sediments. Tertiary sediments constitute the entire thickness of sediments overlying bedrock on the eastern side of Carson Valley, with the exception of Fish Spring Flat (fig. 6). The geometry of geologic units within the transition from Tertiary sediments 
exposed on the eastern side of the valley to Quaternary sediments that cover the western side of the valley has not been well characterized. The Tertiary sediments probably underlie the alluvial fans on the eastern side of the valley and are assumed to underlie basin-fill sediments to the west. The Tertiary sediments could have either been down-dropped sequentially to the west by a wide zone of faults on the eastern side of the valley, or offset within a narrow zone along the hypothesized Hot Springs Mountain fault.

The semi-consolidated nature of the Tertiary sediments makes it difficult to differentiate these sediments from unconsolidated Quaternary sediments based on descriptions in most drillers' logs. During drilling the semi-consolidated sediments are likely broken up and disaggregated, resulting in an appearance similar to that of unconsolidated sediments. Drillers' logs from wells located in exposures of Tertiary sediments often indicate layers of clay exceeding $100 \mathrm{ft}$ in thickness; the drillers' descriptions included the adjectives "cemented" for sand and gravel layers and "hard" for clay layers. Descriptions of "cemented" sand or gravel or "hard" clay have also been noted for sediments at shallow depths where Tertiary sediments are likely hundreds of feet deep, however, suggesting that these descriptive terms from drillers' logs are not always a reliable means for identifying Tertiary sediments. It is also difficult to determine the thickness of clay that could reliably be used to indicate the presence of Tertiary sediments. For these reasons the depth to Tertiary sediments beneath Quaternary sediments and Fish Spring Flat is uncertain.

A few drillers' logs provide descriptions from which the presence or absence of Tertiary sediments can be inferred. On the eastern side of the valley floor, one log describes a "tight and unproductive formation" from about 408 to 700 feet below land surface that probably represents the top of the Tertiary sediments (fig. 5). On the western side of the valley drillers' logs suggest that semi-consolidated Tertiary sediments have not been penetrated. One log for a well near the bedrock ridge south of Gardnerville indicates granite was encountered at a depth of $695 \mathrm{ft}$ below land surface, but another log for a 1,270-ft deep well near Walleys Hot Springs indicates only unconsolidated basin-fill sediments were encountered (fig. 5). Neither log contained descriptions that could be interpreted as clearly identifying Tertiary sediments.

Information from the drillers' logs was used to estimate the geometry of geologic units in the zone of transition from Tertiary sediments on the east to basin-fill sediments on the west. It was assumed that east of the Hot Springs Mountain fault, the top of the Tertiary sediments dips westward at about 2.5 degrees from the westernmost exposure to a depth of 408 $\mathrm{ft}$ at the well where the log indicates the top of Tertiary sediments had been penetrated (fig. 6). It was also assumed that the top of the Tertiary sediments is offset downward about 800 $\mathrm{ft}$ along the inferred Hot Spring Mountain fault, which is consistent with the log south of Gardnerville where granite was encountered at $695 \mathrm{ft}$ and no Tertiary sediments were detected (fig. 5).

\section{Hydrologic Setting}

The hydrology of Carson Valley is dominated by the Carson River. The East and West Forks of the Carson River enter the valley from the south and flow northward to join near Genoa (fig. 4). The combined flow continues northward and exits the valley southeast of Carson City. Streamflow is diverted across the valley floor through a network of unlined canals, ditches, and sloughs that form a complex system for flood irrigation of about 39,000 acres of mainly alfalfa and native pasture grasses (fig. 2; Maurer and Berger, 2007, p. 44). Infiltration of surface water through channels of the Carson River and the irrigation system and beneath irrigated fields maintains a shallow water table beneath much of the western side of the valley floor where depth to ground water is less than $5 \mathrm{ft}$ (fig. 4).

\section{Streamflow and Mountain Runoff}

Streamflows in the East and West Forks of the Carson River and in the Carson River where it exits the valley near Carson City have been measured with overlapping periods of record from 1940 to 2006 (gages 3, 1, and 9, respectively; fig. 7). Average annual flow for the period was 76,200 acre-ft/yr at the West Fork Carson River near Woodfords, California; 267,900 acre-ft/yr at the East Fork Carson River near Gardnerville; and 297,400 acre-ft/yr at the Carson River near Carson City (table 1). Irrigation diversions from the river have been recorded by the Federal Water Master (FWM) since 1984 at 12 locations on major ditches (fig. 7 and table 1).

Mountain runoff is an additional source of streamflow into Carson Valley. Twelve perennial streams tributary to the Carson River drain the Carson Range within the study area (fig. 7; Maurer and others, 2004). Clear Creek also drains the Carson Range and joins the Carson River in the northernmost part of the study area. The combined annual flow of the perennial streams including Clear Creek averaged about 25,000 acre- $\mathrm{ft}$ for water years 1990-2002 (Maurer and others, 2004, p. 14). Flow from the 12 perennial streams (fig. 7) is used for irrigation on land adjacent to the Carson Range during the spring and summer quarters of each water year (termed the irrigation season herein). Three perennial streams drain the southern and eastern parts of Carson Valley. Indian Creek drains uplands adjacent to the Carson Range south of the study area and discharged an average annual flow of about 5,000 acre-ft for water years 1990-2002 (Maurer and Berger, 2007, p. 22). Buckeye and Pine Nut Creeks drain the Pine Nut Mountains, but streamflow only reaches the valley floor and the Carson River during spring runoff in extremely wet years or large floods. The combined, average annual flow for these two streams was about 1,400 acre-ft for water years 1990-2002 (Maurer and others, 2004, p. 14).

Previous reports have estimated daily volumes of mountain runoff. Daily volumes of runoff for the 12 perennial streams draining the Carson Range and Clear Creek were computed 


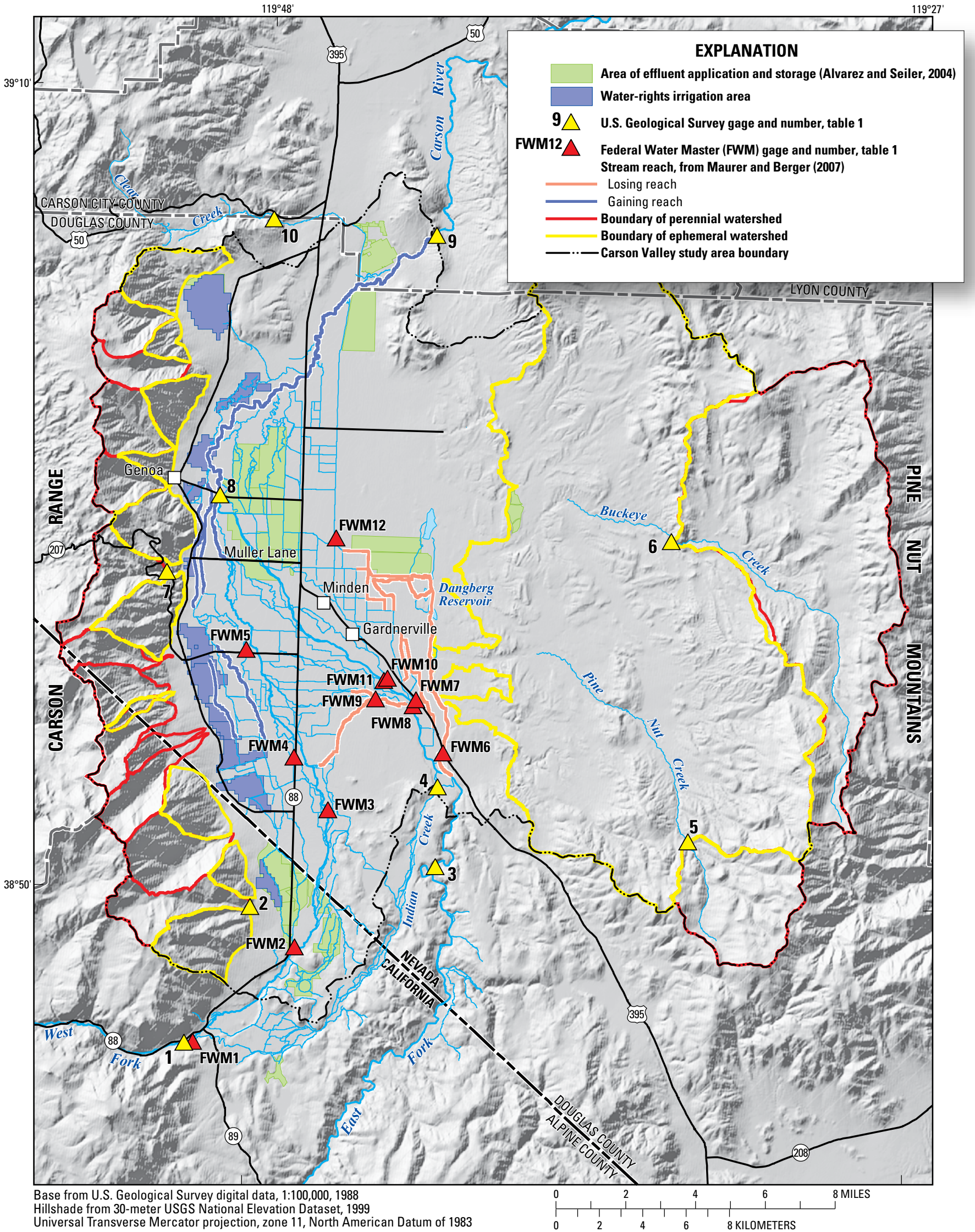

Figure 7. Location of U.S. Geological Survey and Federal Water Master gages, perennial and ephemeral watersheds, areas where effluent has been applied for irrigation, and irrigation distribution system in Carson Valley. 
Table 1. USGS and FWM gaging stations on the Carson River and selected tributaries and diversion ditches.

[Flow data from gages shown in bold were used in model calibration]

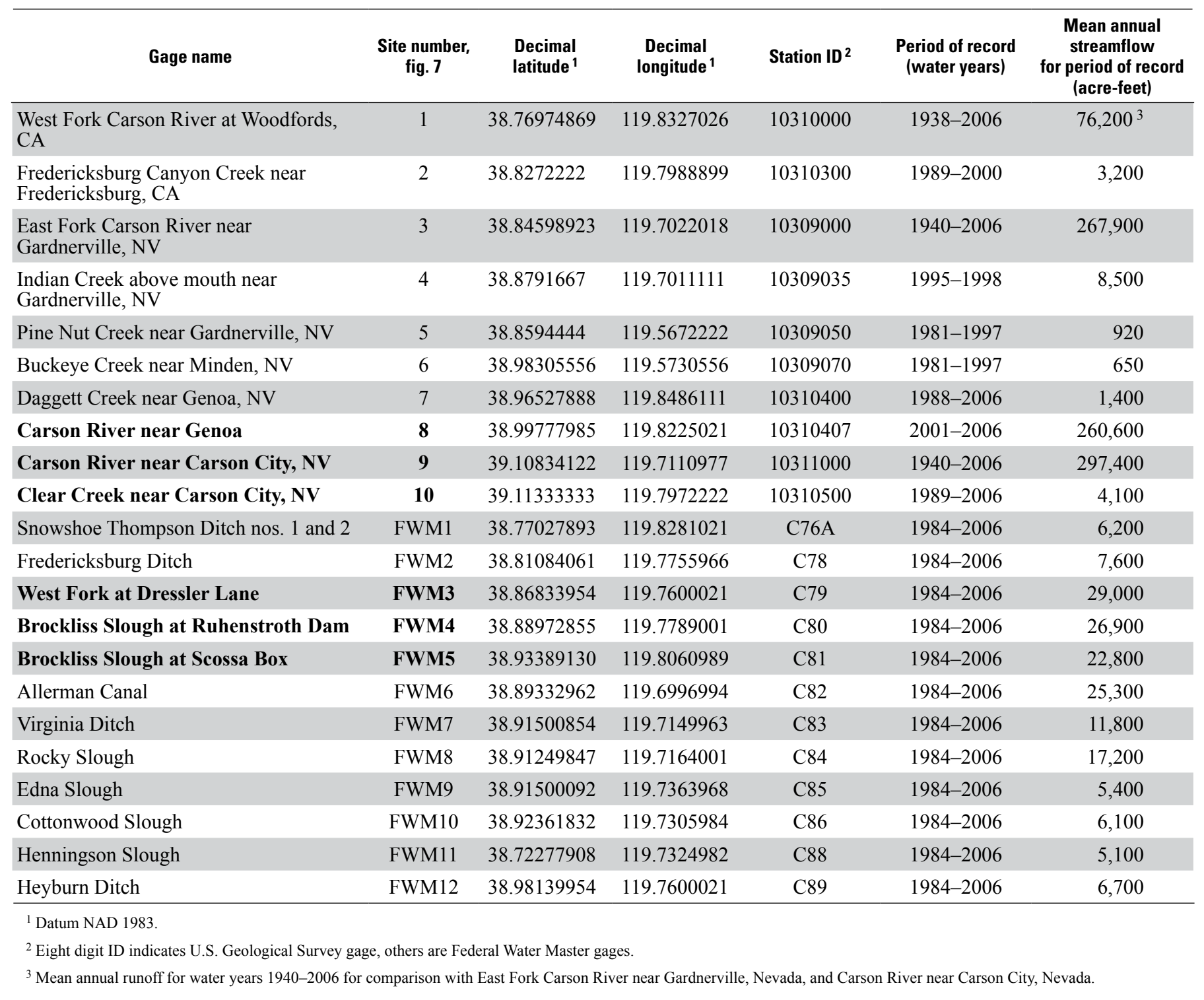

or estimated for the period 1990-2002 by Maurer and others (2004) using gage data and miscellaneous streamflow measurements. The estimated daily volumes of runoff provided information for the calibration of watershed models developed by Jeton and Maurer (2007) using the PRMS. The watershed models were based on climate data consisting of daily values of precipitation, minimum and maximum air temperature, and on land-cover and soils maps, and topography. PRMS model output for each watershed consisted of daily values for runoff, evapotranspiration, and groundwater recharge to basin-fill sediments in Carson Valley. Parameters from the perennial watershed models were used to estimate mountain runoff from the intervening ephemeral watersheds for the period 19902002 (fig. 7; Jeton and Maurer, 2007, p. 45).
Mountain-front recharge refers to groundwater recharge from mountain watersheds to the Quaternary basin-fill sediments in Carson Valley, together with infiltration of streamflow near the base of the mountains. Maurer and Berger (2007, p. 36) concluded that runoff from ephemeral watersheds in the Carson Range recharges the Quaternary sediments, whereas runoff from perennial watersheds does not. Runoff from perennial watersheds either flows to the Carson River during winter and spring or is diverted to irrigated lands during the irrigation season. The conclusion that ephemeral runoff infiltrates to Quaternary sediments is based on the lack of active channels across alluvial fans adjacent to the Carson Range. The conclusion that runoff from perennial watersheds does not infiltrate to Quaternary sediments is based on streamflow 
measurements of perennial streams where they cross the alluvial fans that indicate that little flow is lost to infiltration. The lack of infiltration could result from a shallow water table that is established near perennial stream channels. Runoff from both perennial and ephemeral watersheds in the Pine Nut Mountains is assumed to recharge the Tertiary sediments.

\section{Irrigation}

Since about 1980, irrigation of land in Carson Valley has been guided by the Alpine Decree (U.S. District Court, 1980). The Alpine Decree adjudicates the surface-water rights for the Carson River and is based largely on historical practices in place since the late 1800s (U.S. District Court, 1980, p. 5). Under the Decree, the distribution of surface water is based on the prior appropriation doctrine, which holds that the first person to have put the water to beneficial use has a higher priority, or right, to the water than subsequent users. The Decree lists the year that water was first put to beneficial use for about 800 individual claims, as well as the location and total acreage irrigated and the source from which the water is diverted. The FWM uses the Alpine Decree to manage the irrigation system and distribute water across the valley. Land irrigated by runoff from the 12 perennial streams draining the Carson Range, referred to as water-rights areas herein (fig. 7), is not included in the Alpine Decree.

Other sources of irrigation water include groundwater and wastewater effluent. Groundwater is pumped mainly from Quaternary sediments and generally discharged to ditches in the irrigation system and applied by flood irrigation. However, some sprinkler irrigation systems have been in operation since the mid-1980s southeast of the Gardnerville Ranchos and since the late 1990s on the eastern side of the valley (fig. 7). Wastewater effluent imported from the Lake Tahoe basin and generated within Carson Valley is also stored and used for irrigation (fig. 7). Maurer and Berger (2007, p. 41) estimated effluent applied for irrigation averaged about 9,500 acre- $\mathrm{ft}$ annually during 1990-2005.

Water applied for irrigation either returns to the irrigation system through surface runoff (return flow, also referred to as tail water), is lost through evapotranspiration (ET), or infiltrates to the water table. Return flow from irrigated fields in Carson Valley in the 1970s was estimated to be 30 to 50 percent of the applied water (Guitjens and Mahannah, 1972; Guitjens and others, 1976; and Guitjens and others, 1978). Since the 1980s laser-leveling of agricultural fields has probably improved irrigation efficiency and reduced losses to return flow to 20 to 30 percent of the applied water (Arlen Neil, Vada Hubbard, Natural Resources Conservation Service, oral commun., 2006).

\section{Groundwater Pumpage}

Groundwater pumpage for domestic, municipal, and industrial use in Carson Valley has increased greatly since 1971 when it was about 600 acre-ft/yr. Pumpage for irrigation ranged from about 3,000 acre-ft/yr in wet years to 10,000 acre-ft/yr in dry years in the early 1970s (Glancy and Katzer, 1976 , p. 59). Total annual pumpage had increased to as much as 20,000 acre-ft/yr by the late 1990 s (fig. 8), and total pumpage increased to $31,000 \mathrm{acre}-\mathrm{ft} / \mathrm{yr}$ in 2004 , a relatively dry year (Maurer and Berger, 2007, p. 42). Agricultural irrigation has historically been the greatest use of pumped water, with lesser volumes pumped during wet years when sufficient surface water was available for irrigation, and greater volumes pumped during dry years. Pumpage for irrigation decreased from 67 percent of the total volume pumped in 1970 to 29 percent in 2005. This reduction in pumpage was primarily offset by an increase in pumping for municipal use, which increased to about 10,000 acre-ft annually by 2000 . Domestic pumpage accounted for about 16 percent of the total volume of water pumped in 2005. Historical pumping rates were estimated from inventories conducted by the Nevada State Engineer's Office for water years 1987-2005 (Scott Clark, Tony Eng, Nevada Division of Water Resources (NDWR), written and oral commun., 2006, 2007), inventories made by the USGS for water years 1981-87 (Maurer, 1986, p. 62-63; Berger, 1987, p. 14; Berger, 1990, p. 9), and estimates made by Maurer and others $(2009$, p. 40) for water years 1946-81.

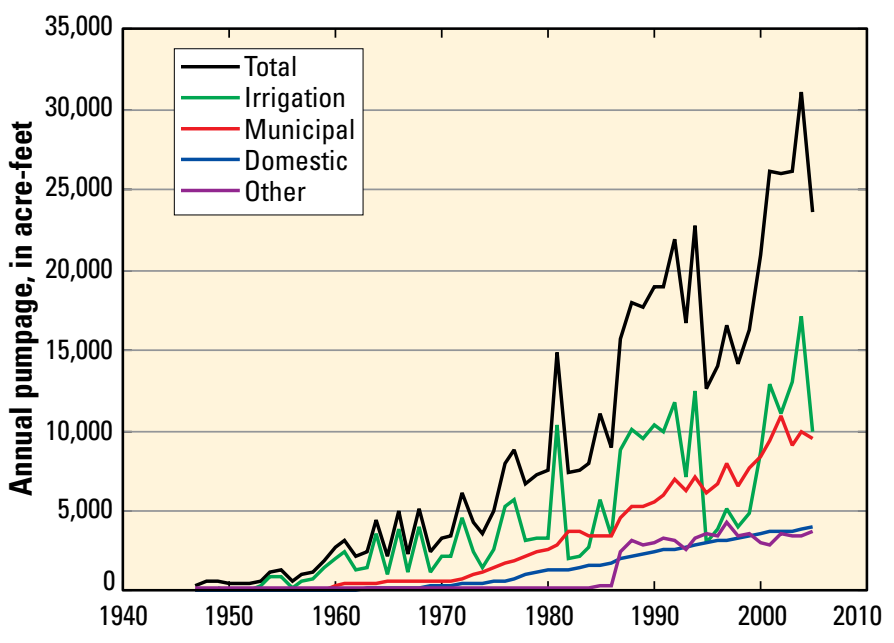

Figure 8. Groundwater pumpage for irrigation, municipal, domestic and other uses in Carson Valley, 1946-2005. 


\section{Transmissivity}

The transmissivity of Tertiary and Quaternary sediments of Carson Valley was initially estimated from aquifer tests of 37 wells in Carson Valley (table 2 and fig. 5). The aquifer test data were obtained from files at the USGS office in Carson City, Nevada, Douglas County, and water purveyors in Carson Valley. Most of the data were collected from municipal-supply wells from single-well tests conducted using step-drawdown and constant-rate pumping; seven of the tests used multiple observation wells. Twenty-two of the aquifer tests were analyzed using the spreadsheet program of Halford and Kuniansky (2002) based on the Cooper-Jacob, straight-line method (Cooper and Jacob, 1946) to analyze constant rate tests, and a method developed by Lee (1982) to analyze step-drawdown tests. Transmissivity estimates (table 2 ) are averages of two estimates for wells that have both constant-rate and stepdrawdown tests. Most of the remaining tests were analyzed by ECO:LOGIC (2000-05, various references listed in table 2, on file at the USGS office in Carson City) using a program called Well Hydraulics Interpretation Package (WHIP) developed by Hydro-Geo Chem, Inc. (1988). Selected aquifer-test data analyzed by ECO:LOGIC using the WHIP program were reanalyzed using the program of Halford and Kuniansky (2002). The resulting estimates of transmissivity and storage were almost identical.

Estimates of transmissivity ranged from 20 to 31,000 feet squared per day $\left(\mathrm{ft}^{2} / \mathrm{d}\right.$; table 2$)$. Most aquifer tests were conducted in wells screened in Quaternary sediments, although two wells are screened entirely in Tertiary sediments. The tops and bottoms of the known screened intervals of the wells tested ranged from 40 to $305 \mathrm{ft}$ and from 86 to $650 \mathrm{ft}$ below land surface, respectively, with the exception of well 29. Well 29 is screened from 100 to $1,100 \mathrm{ft}$ below land surface and penetrates the entire thickness of Tertiary sediments on the eastern side of Carson Valley (fig. 5). The largest values of transmissivity (more than $15,000 \mathrm{ft}^{2} / \mathrm{d}$ ) were estimated for wells screened in Quaternary basin-fill sediments within about $0.5 \mathrm{mi}$ of the Carson River and at well 21 near the eastern side of the valley floor. Drillers' logs indicate these wells penetrate well-sorted gravel and sand deposited by the Carson River. Much lower values of transmissivity (160 to $800 \mathrm{ft}^{2} / \mathrm{d}$ ) were estimated for the two wells screened entirely in Tertiary sediments.

The specific capacity (ratio of well yield to drawdown) of pumped wells was also used to estimate transmissivity in areas where aquifer-test data were not available (Lohman, 1972, p. 52). A relation was developed between the transmissivity estimated from the aquifer tests and the specific capacity for the 37 wells for which both transmissivity and specific capacity data were available (fig. 9). The relation indicates that specific capacity is proportional to transmissivity and that a linear model can explain 84 percent of the variability of

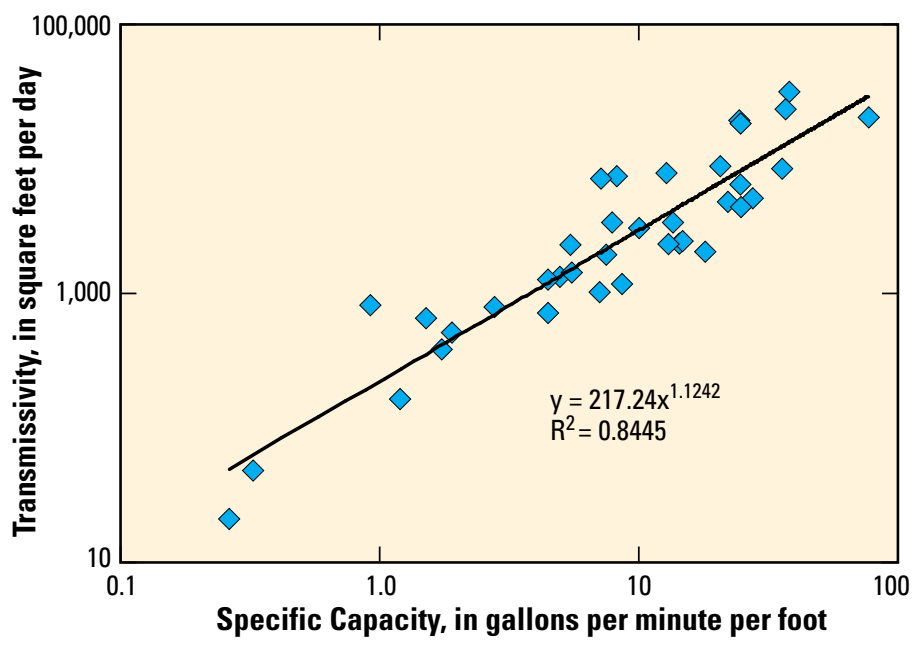

Figure 9. Relation between transmissivity estimates obtained from specific capacity and aquifer-test data.

the data. This relation was used to estimate transmissivity for about 1,100 wells with specific-capacity data in Carson Valley (fig. 10). The screened length of the 1,100 wells ranges from 4 to $540 \mathrm{ft}$, with 114 wells having screened lengths greater than $99 \mathrm{ft}$. No significant relation was apparent between the screened length and the estimated transmissivity for the 1,100 wells.

The 114 wells with screened lengths greater than $99 \mathrm{ft}$ were divided into three groups according to the type of sediment screened by each well: (1) Quaternary alluvial fan, (2) Quaternary fluvial, and (3) Tertiary sediments (fig. 11). The median transmissivity computed for each group was $316 ; 3,120$; and $110 \mathrm{ft}^{2} / \mathrm{d}$, respectively. An analysis of variance indicates that transmissivity is significantly larger in wells screened in Quaternary fluvial sediments, but there is no significant difference in transmissivity between wells screened in Quaternary alluvial fan and Tertiary sediments. A similar analysis was conducted by dividing all 1,100 wells into the same three groups, but no significant differences were found, probably because there are a large number of wells with relatively short screens (less than $20 \mathrm{ft}$ ) that do not accurately reflect the overall transmissivity of each sediment type. 


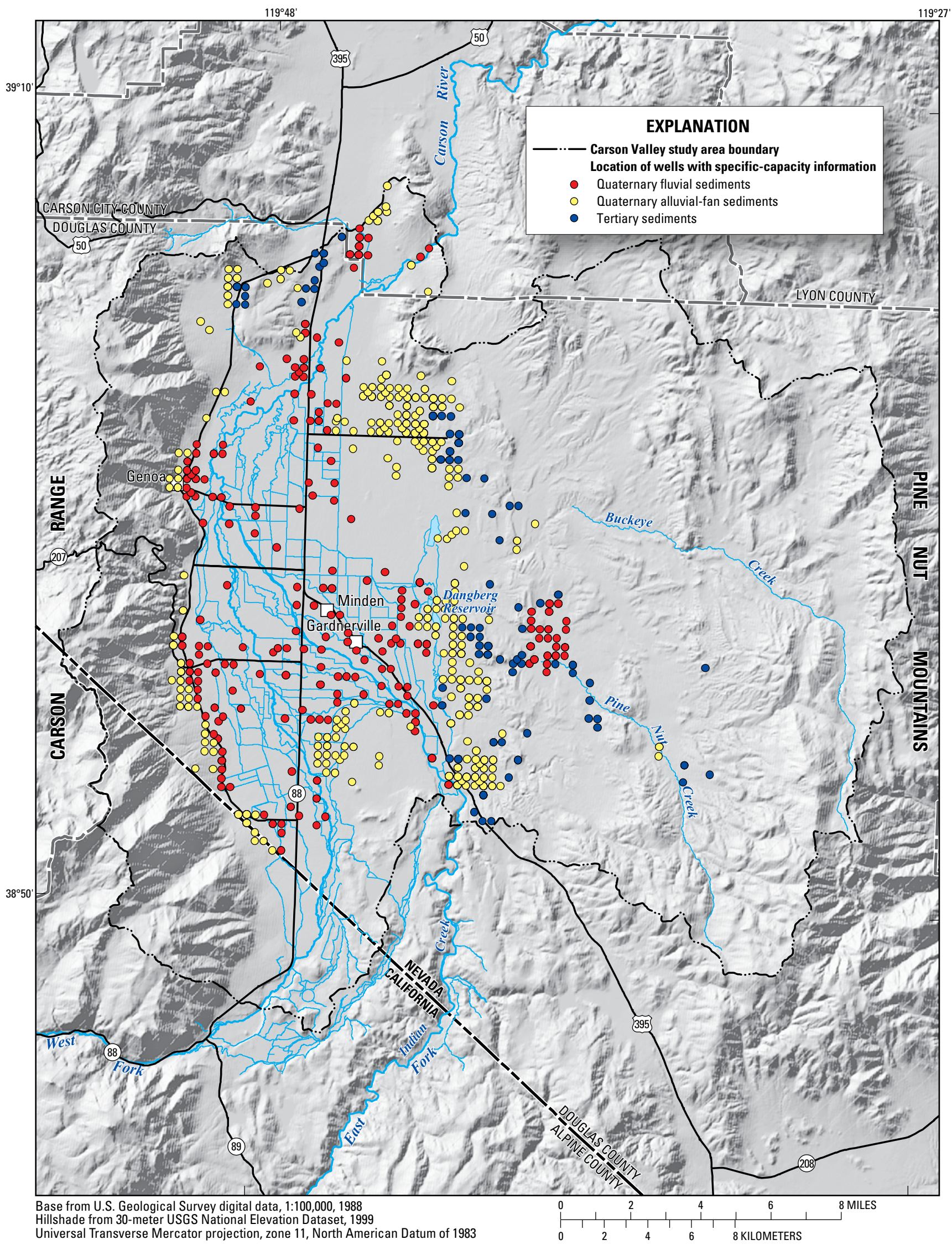

Figure 10. Location of wells with specific-capacity data from drillers' logs. 


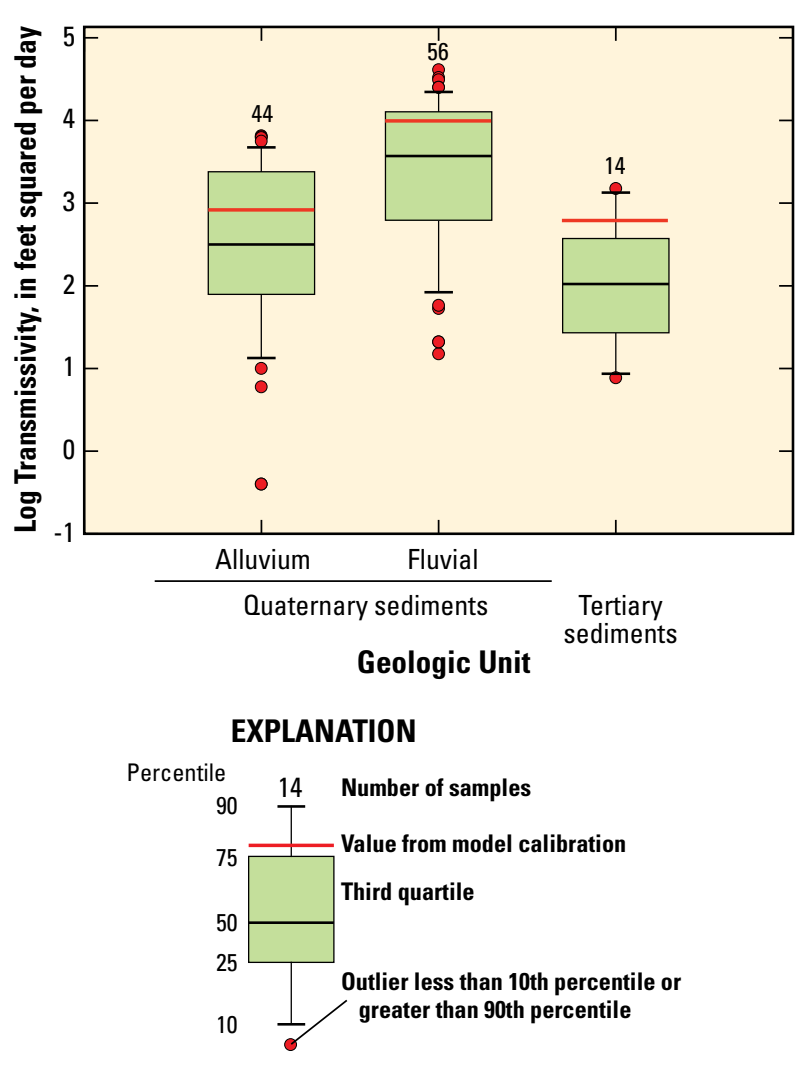

Figure 11. Distribution of transmissivity in wells with screen lengths greater than 99 feet in Quaternary and Tertiary sediments.

A kriged interpolation of the log-transformed values of transmissivity from the 114 wells was computed with an assumed Guassian variogram with a variance (sill) of $1.0\left(\mathrm{ft}^{2} / \mathrm{d}\right)^{2}$, a nugget of $0.45\left(\mathrm{ft}^{2} / \mathrm{d}\right)^{2}$ and a range of $11,000 \mathrm{ft}$. The distribution of transmissivity indicates larger values in the central part of the valley underlying the East and West Forks of the Carson River, with smaller values along the valley margins (fig. 12). This pattern is similar to that mapped by Prudic and Herman (1996) for the Paradise Valley in Humboldt County, Nevada.

\section{Storage}

Estimates of the distribution of specific yield in Carson Valley were made by Dillingham (1980, p. 23) using descriptions of aquifer materials in 250 drillers' logs (fig. 13). The resulting map shows areas of specific yield greater than 20 percent approximately parallel to the East Fork Carson River west of the Minden/Gardnerville area, near the center of the valley, and in small areas on the eastern side of the valley and near the state line on the southwestern side of the valley. Estimated specific yield is about 15 percent throughout most of the valley, but decreases to 10 percent around the margins of the valley and beneath the Carson River in the northern part of the valley. Morris and Johnson (1967) reported ranges of specific yield for different types of rocks and sediments based on laboratory determinations of samples collected throughout the United States from 1948 to 1960 and analyzed at the USGS Denver laboratory. Ranges in values determined for water-laid sediments, typical of those in Carson Valley, were from 17 to 20 percent for silt and clay, from 28 to 45 percent for sand, and from 31 to 44 percent for gravel (Morris and Johnson, 1967, p. 22-24). These ranges suggest the values of specific yield estimated by Dillingham (1980) on the basis of lithology could be underestimated. The mapped values shown in figure 13 , therefore, are assumed to qualitatively depict the distribution of specific yield in the Carson Valley. Aquifer tests listed in table 2 also include estimates of storage coefficient values ranging from 0.1 , representing unconfined conditions, to 0.0002 , representing confined conditions, but values estimated from single-well tests are considered approximations only. 


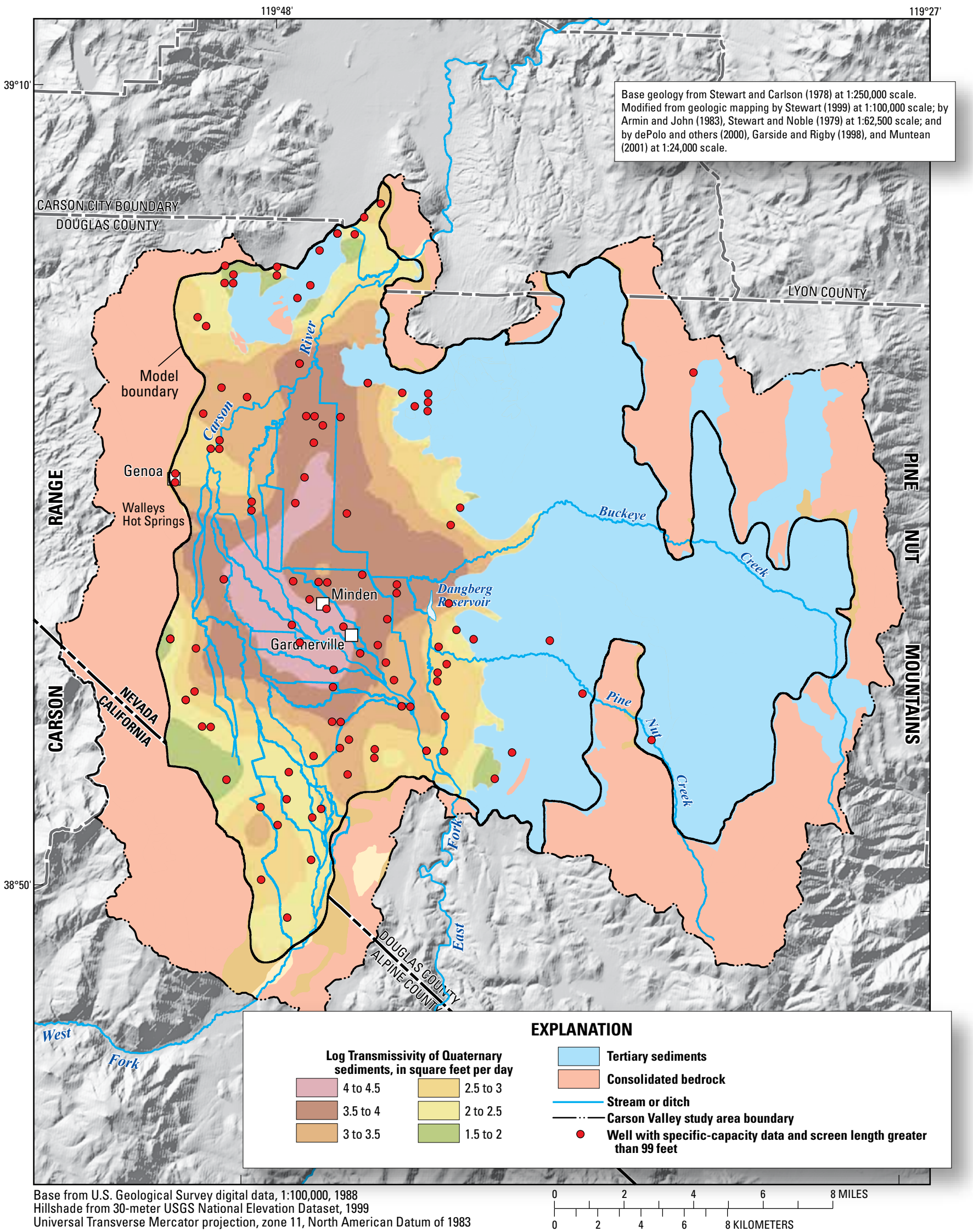

Figure 12. Location of wells with screened lengths greater than 99 feet and the kriged distribution of log transmissivity. 


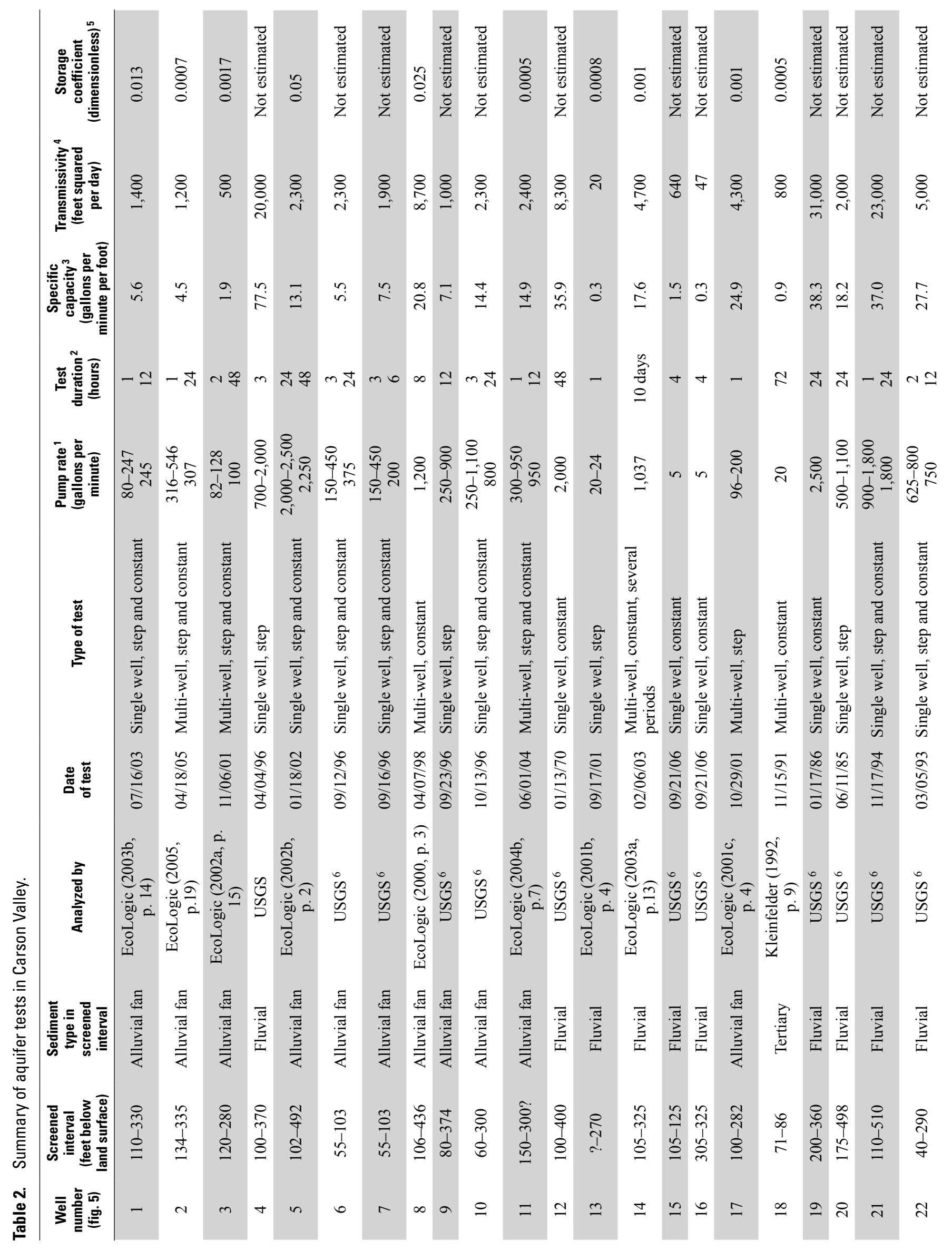




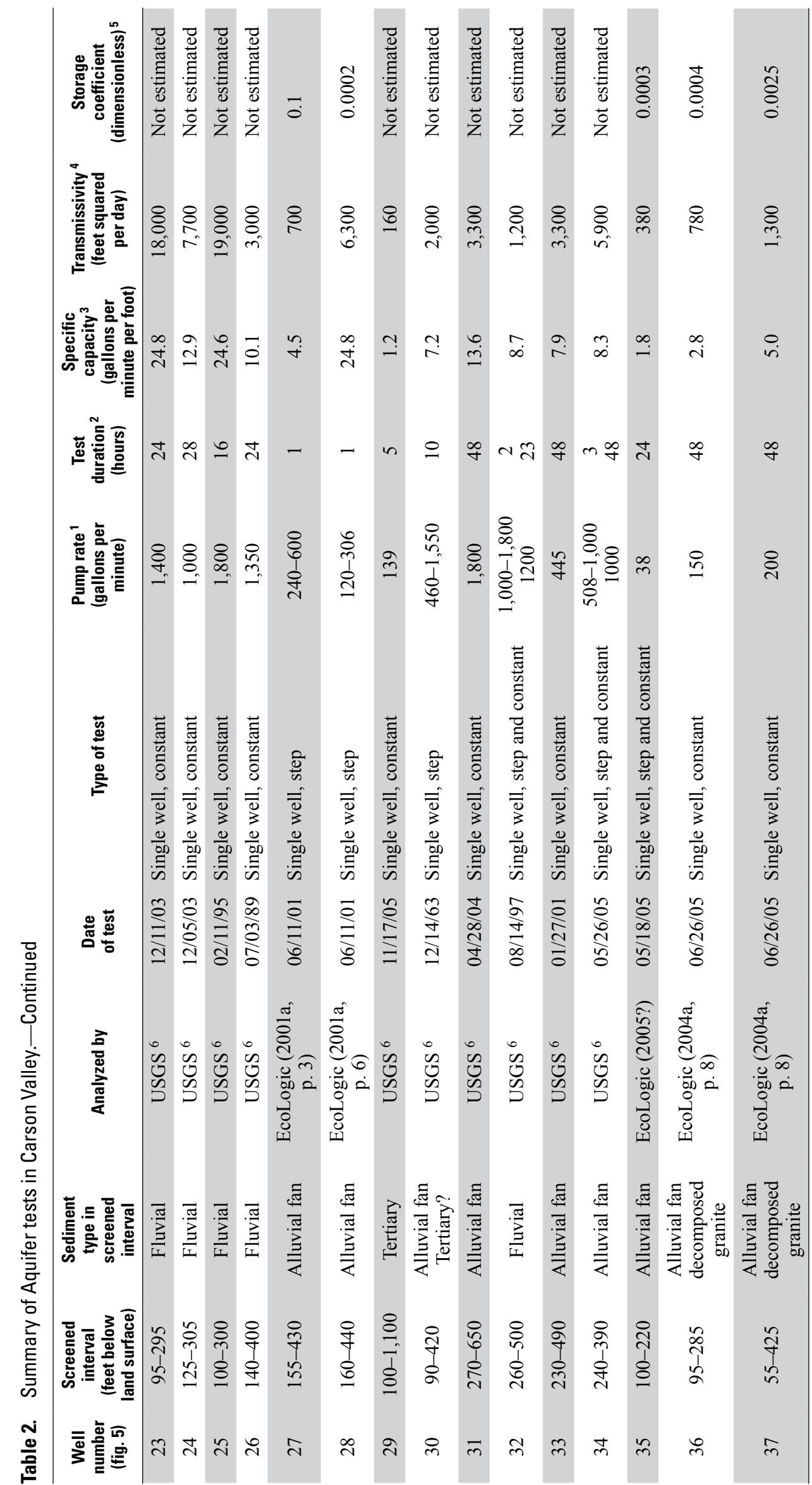




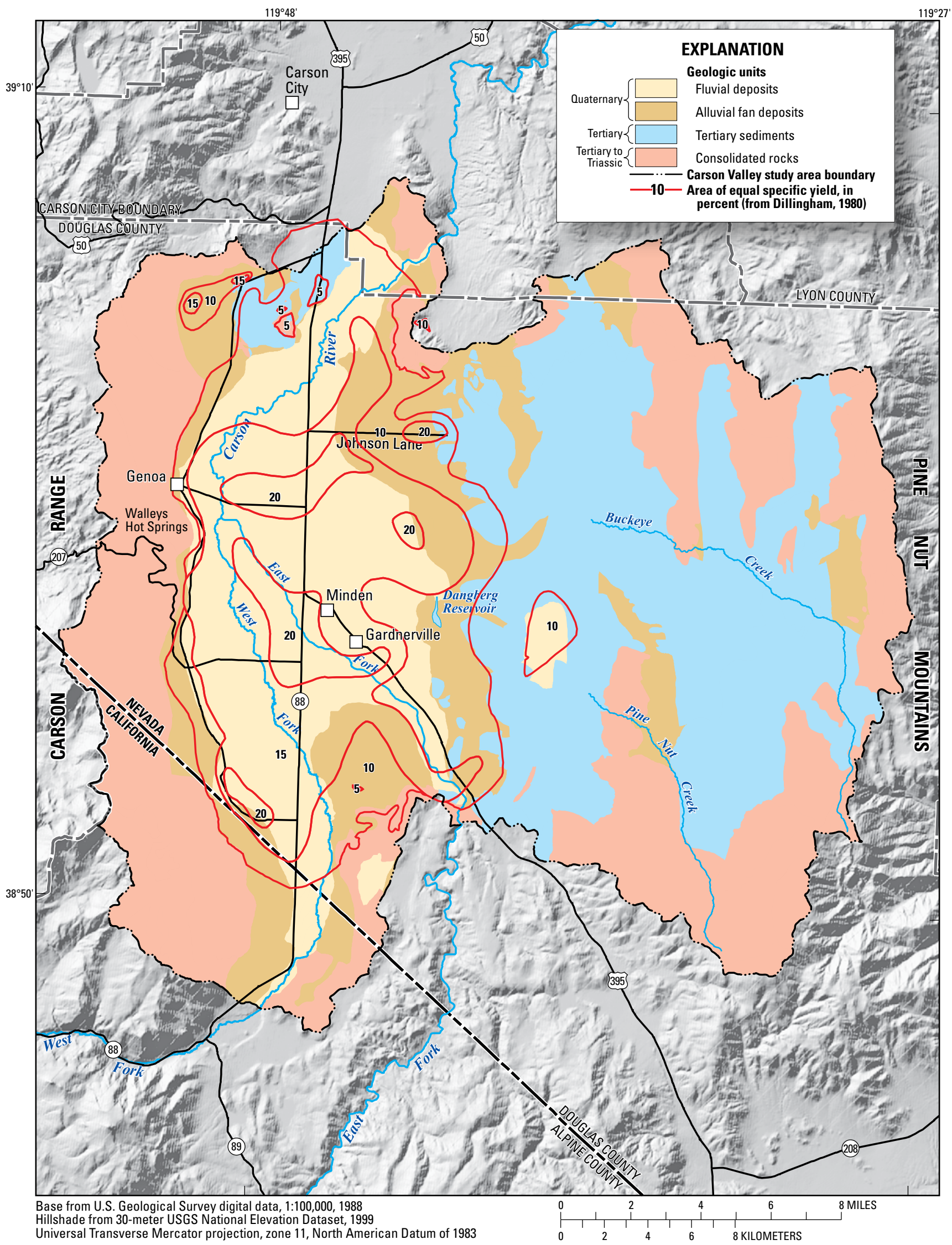

Figure 13. Geologic units and the estimated distribution of specific yield in basin-fill sediments of Carson Valley from Dillingham (1980). 


\section{Groundwater Flow}

Previous investigations show that groundwater flows from the west and east towards the Carson River and then northward (fig. 14; Berger and Medina, 1999). Along the northsouth axis of the valley, hydraulic gradients range from about 100 feet per mile $(\mathrm{ft} / \mathrm{mi})$ in the southwestern part of the valley to about $5 \mathrm{ft} / \mathrm{mi}$ in the northern part of the valley. The hydraulic gradient is eastward at about $100 \mathrm{ft} / \mathrm{mi}$ beneath alluvial fans on the western side of the valley, whereas gradients are westward and range from 20 to $100 \mathrm{ft} / \mathrm{mi}$ on the eastern side of the valley (Maurer, 1986, p. 18). Water-level data for Tertiary sediments exposed on the eastern side of the valley are sparse, but indicate a gradient toward the west. Water levels near Indian Hills in the northwestern part of the valley, not included on the map developed by Berger and Medina (1999) but available in the NWIS database, indicate a gradient from Jacks Valley toward Carson Valley through Tertiary sediments beneath Indian Hills.

The bedrock surrounding and underlying Carson Valley is relatively impermeable to groundwater flow, although many wells drilled in these rocks produce sufficient water for domestic use. In the semi-consolidated Tertiary sediments, lenses of sand and gravel are the main water-bearing units and probably transmit most groundwater flow. The Quaternary sediments that form alluvial fans surrounding the valley and fluvial deposits that underlie the flood plain of the Carson River are the principal aquifers in Carson Valley (Maurer, 1986, p. 17).

An upward hydraulic gradient exists throughout most of the valley (Maurer, 1986, p. 17) and artesian flow (indicating confined conditions) occurs in some wells screened at depths greater than 200 to $300 \mathrm{ft}$ below land surface. Dillingham (1980, p. 40), however, concluded from inspection of drillers' logs that a continuous confining unit is not present throughout the valley. Confined conditions likely result from discontinuous clay beds that are 30 to $40 \mathrm{ft}$ thick and occur at depths of 200 to $300 \mathrm{ft}$. Confined conditions and artesian flow also occur at shallower depths (less than $100 \mathrm{ft}$ ) on the western side of the valley. At these locations, the distal portions of coarse-grained alluvial fans have probably been buried by fine-grained floodplain deposits of the Carson River, creating confined conditions (Maurer, 1986, p. 17).

\section{Exchange of Groundwater and Surface Water}

In the center of the valley where the water table is shallow, groundwater is hydraulically connected to the network of streams and irrigation ditches. Maurer and Berger (2007, p. 51) compared streambed temperatures and groundwater levels with stream stage and concluded that the greatest losses from the Carson River and the irrigation system (ditches and canals) to groundwater occur mainly in the southeastern part of the valley, although losses also occur in other parts of the valley during the irrigation season and in wet years.
In contrast, both the Carson River and the irrigation system appeared to gain flow from groundwater discharge on the western side of the valley and north of Muller Lane (fig. 7).

The direction of the hydraulic gradient between the water table and stream changes between wet and dry years, and during the irrigation season, resulting in a complex pattern of flow. Maurer and Berger (2007, p 24) calculated the difference between mean daily surface-water inflow to and outflow from Carson Valley for the period 1990-2002 using the measured flow of the Carson River and estimates of mean-daily streamflow in tributaries. The calculations indicated that surfacewater inflow to the basin was greater than outflow from the basin during the irrigation season (when the evapotranspiration rate was high), and that streamflow losses to groundwater and consumptive use during the period averaged about $89,000 \mathrm{acre}-\mathrm{ft} / \mathrm{yr}$. Conversely, surface-water outflow from the basin was greater than inflow to the basin during the winter and spring (when the evapotranspiration rate was low) when streamflow gains totaled about 16,000 acre-ft. A net annual loss of streamflow in Carson Valley of 73,000 acre-ft/yr was, therefore, computed for the period 1990-2002.

\section{Groundwater Levels}

Groundwater levels have been measured by the USGS in about 70 wells in Carson Valley since December 2004 (selected wells are shown on fig. 14). Measurements were first made in many of these wells in the early 1980s for a study by Maurer (1986) and additional measurements have been made at various times through 2004. Water levels in alluvialfan sediments on the western side of Carson Valley showed seasonal fluctuations of about 5 to $35 \mathrm{ft}$ during the early 1980s (fig. 15A) and fluctuations of as much as $40 \mathrm{ft}$ in response to the transition from wet periods to dry periods (1985-92, wells 1 and 2). Shallow wells on the valley floor indicate smaller magnitude seasonal and long-term fluctuations ranging from about 2 to $8 \mathrm{ft}$, although data for dry years in the late 1980s and wet years in the mid 1990s are not available for many wells (fig. 15B). Although groundwater levels fluctuate in response to both seasonal and annual variations in recharge, water levels among multiple wells do not display a long-term trend over the period of record, indicating that the aquifer is in a state of dynamic equilibrium.

Water levels in artesian wells can fluctuate from about 5 to $20 \mathrm{ft}$ above land surface during winter months to about 10 to $20 \mathrm{ft}$ below land surface during summer months when pumping for irrigation occurs (fig. 15C). No obvious trend in water levels is apparent in these wells from 1981 to 2005. Water levels in deep irrigation wells (fig. 15D) appear to have declined 5 to $10 \mathrm{ft}$ by 2005 since the mid-1990s, possibly in response to dry conditions. The largest declines in water level have occurred on the eastern side of Carson Valley where areas of increased development are supplied largely by individual domestic wells (fig. 15E). In the Johnson Lane area (well 5), water levels declined about $10 \mathrm{ft}$ from 1981 to 2005, while 


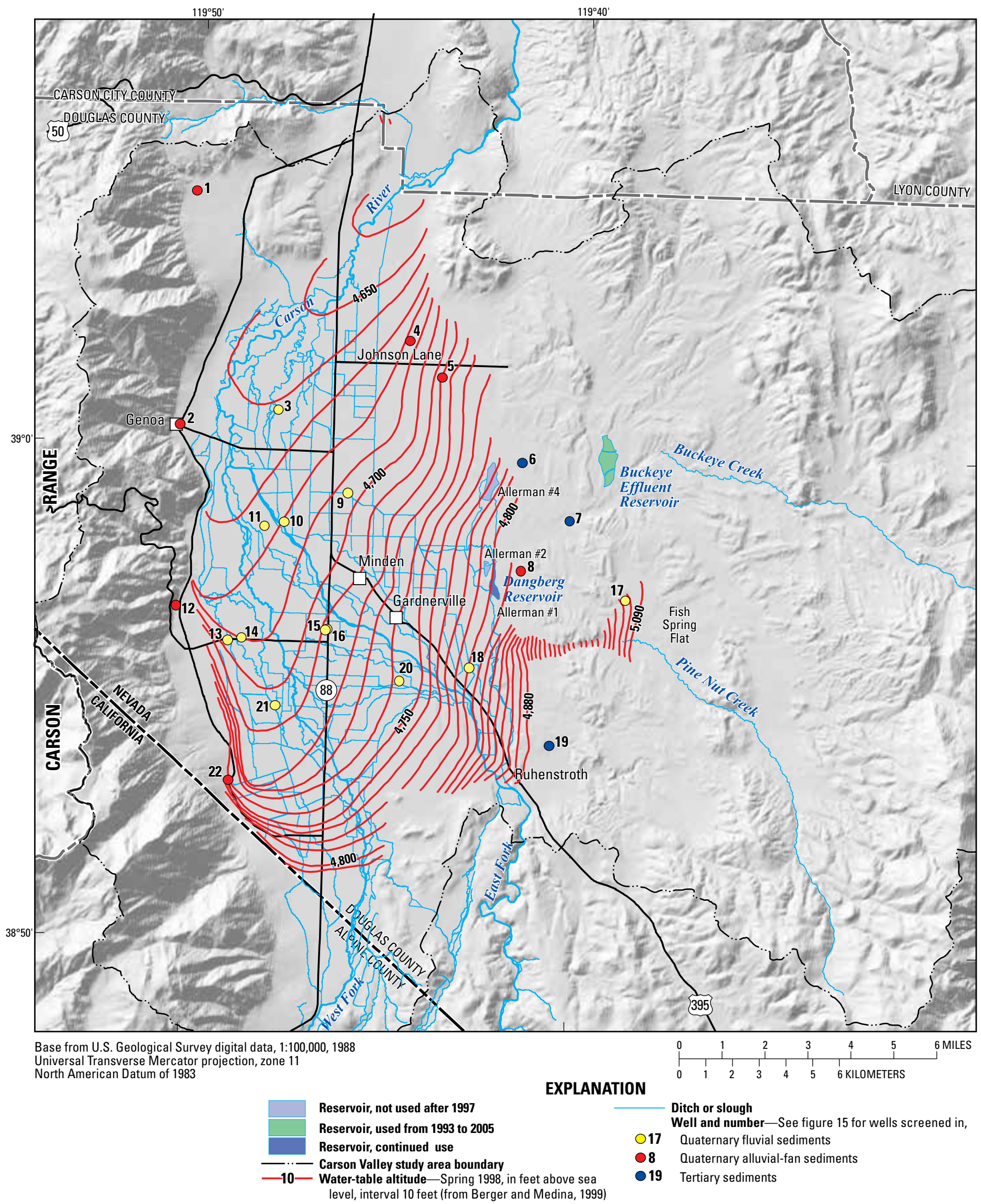

Figure 14. Water-table altitude in Carson Valley, spring 1998. 


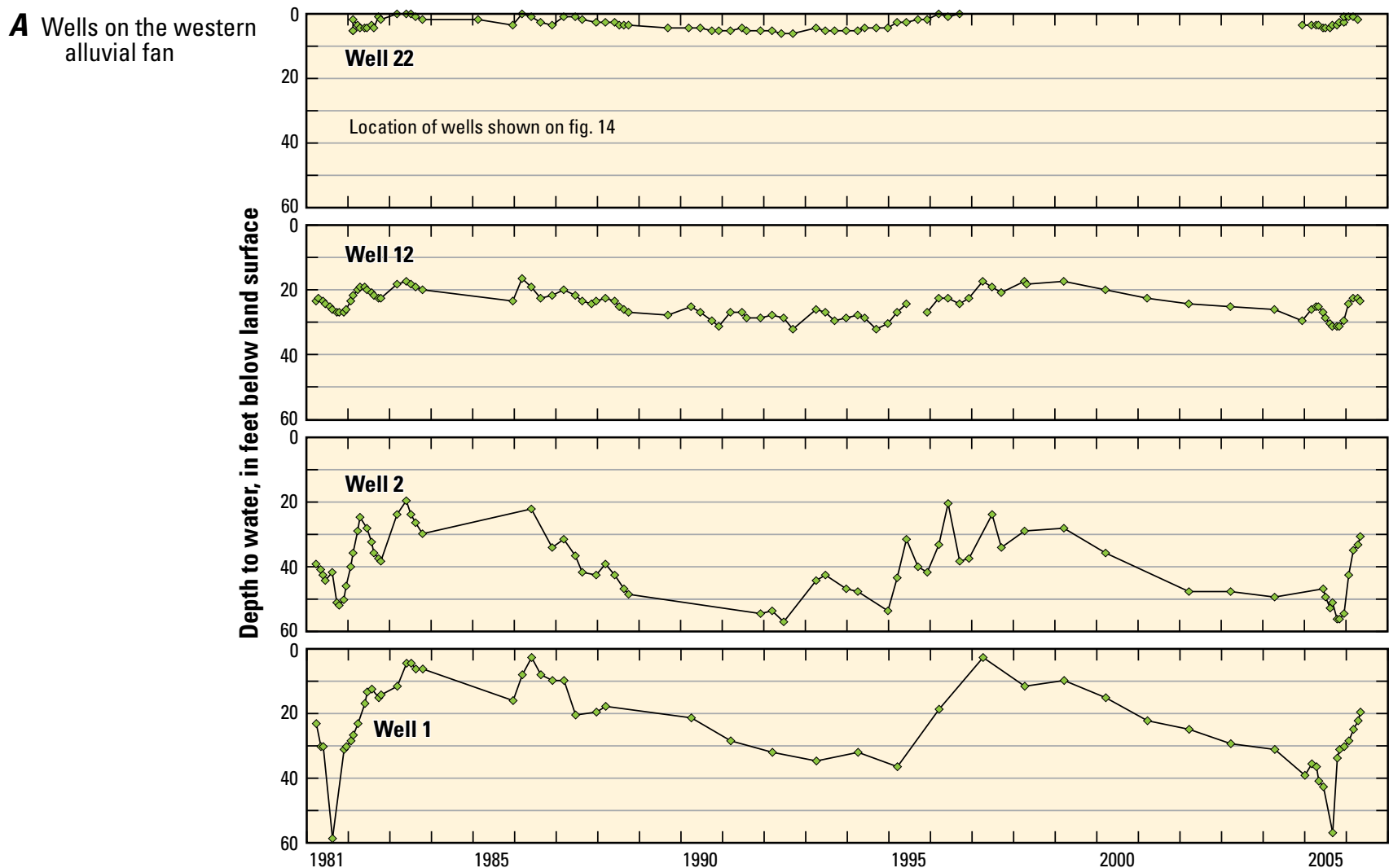

B Shallow wells on the valley floor

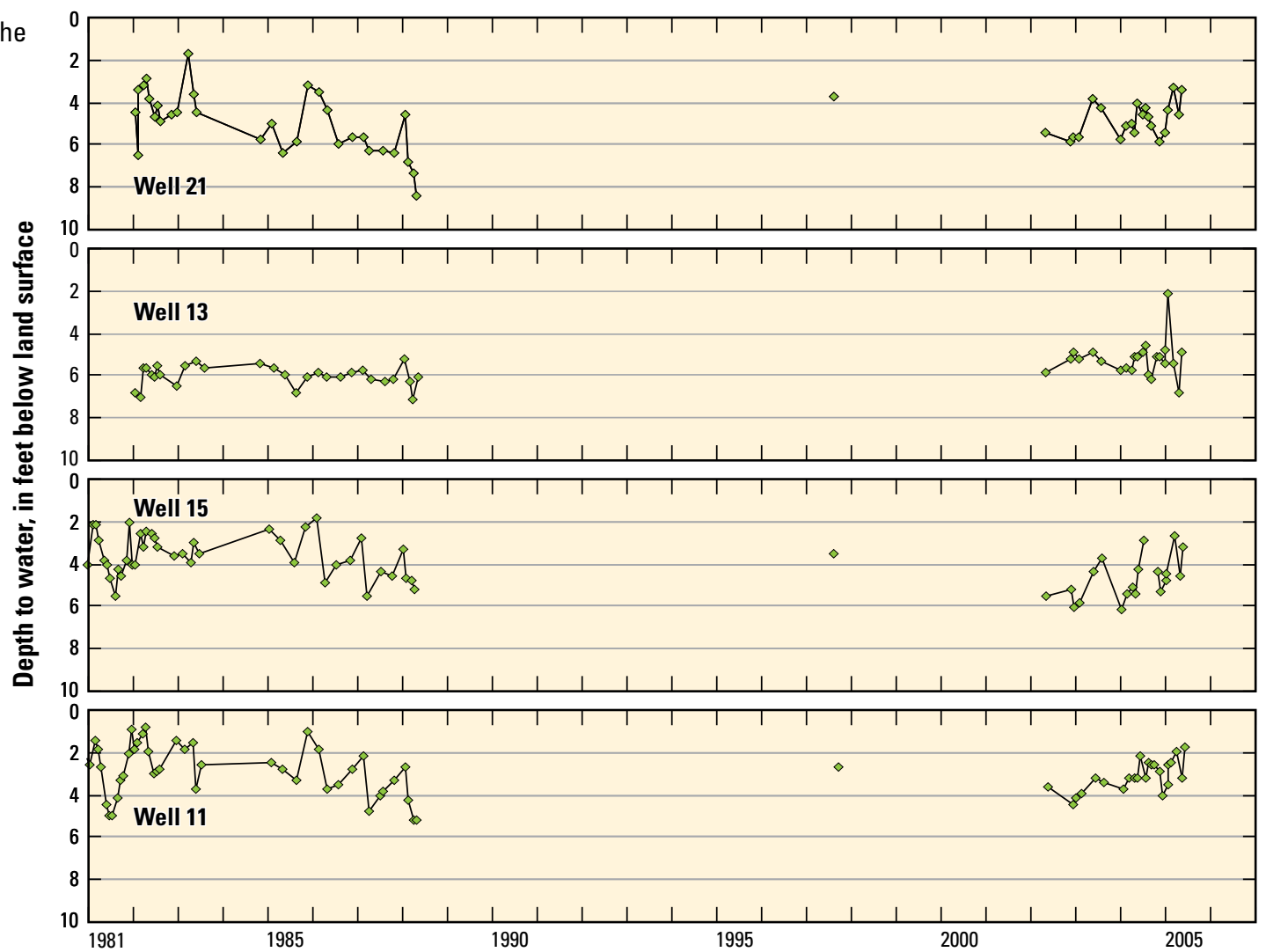

Figure 15. Water-level fluctuations, 1981-2006, in $A$, wells on the western alluvial fans; $B$, shallow wells on the valley floor; $C$, deep flowing wells on the valley floor; $D$, deep irrigation wells near the valley floor; $E$, wells on the eastern side of the valley; and $F$, wells with water levels affected by changes in water use. 
C Deep flowing wells on the valley floor

D Deep irrigation wells near the valley floor
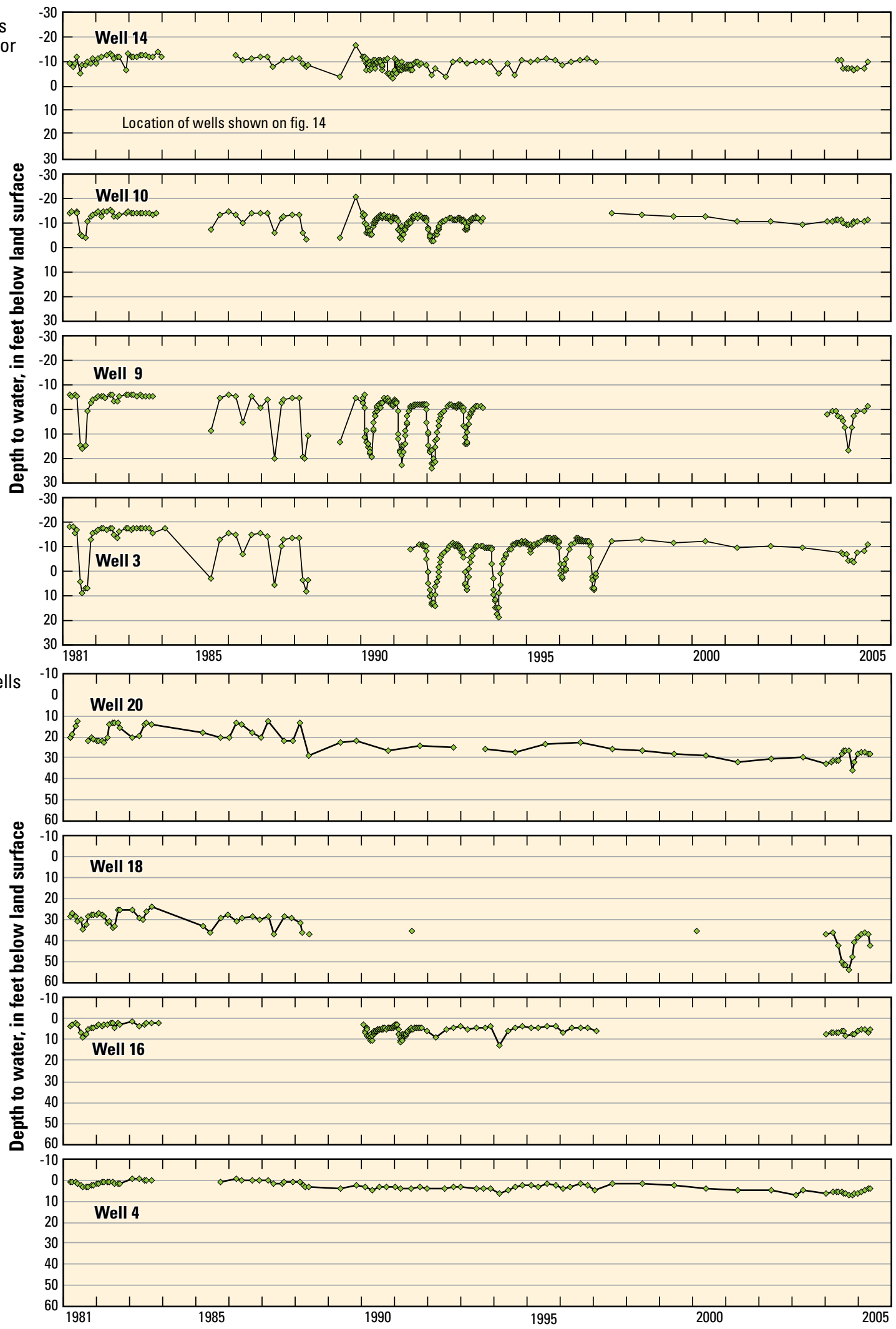

Figure 15. Water-level fluctuations,1981-2006, in $A$, wells on the western alluvial fans; $B$, shallow wells on the valley floor; $C$, deep flowing wells on the valley floor; $D$, deep irrigation wells near the valley floor; $E$, wells on the eastern side of the valley; and $F$, wells with water levels affected by changes in water use.-Continued 
$\boldsymbol{E}$ Wells on the eastern side of the valley

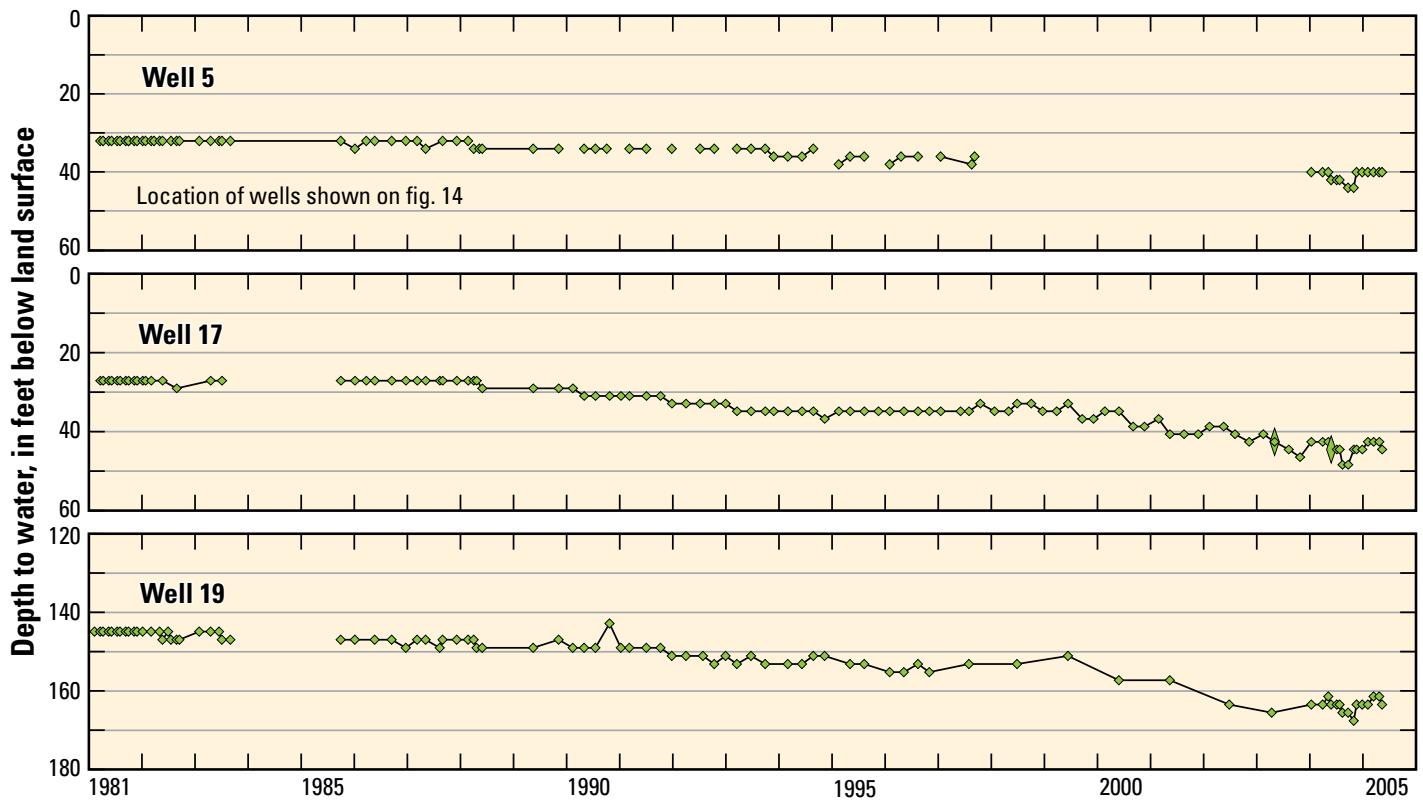

$\boldsymbol{F}$ Wells with water levels affected by changes in water use

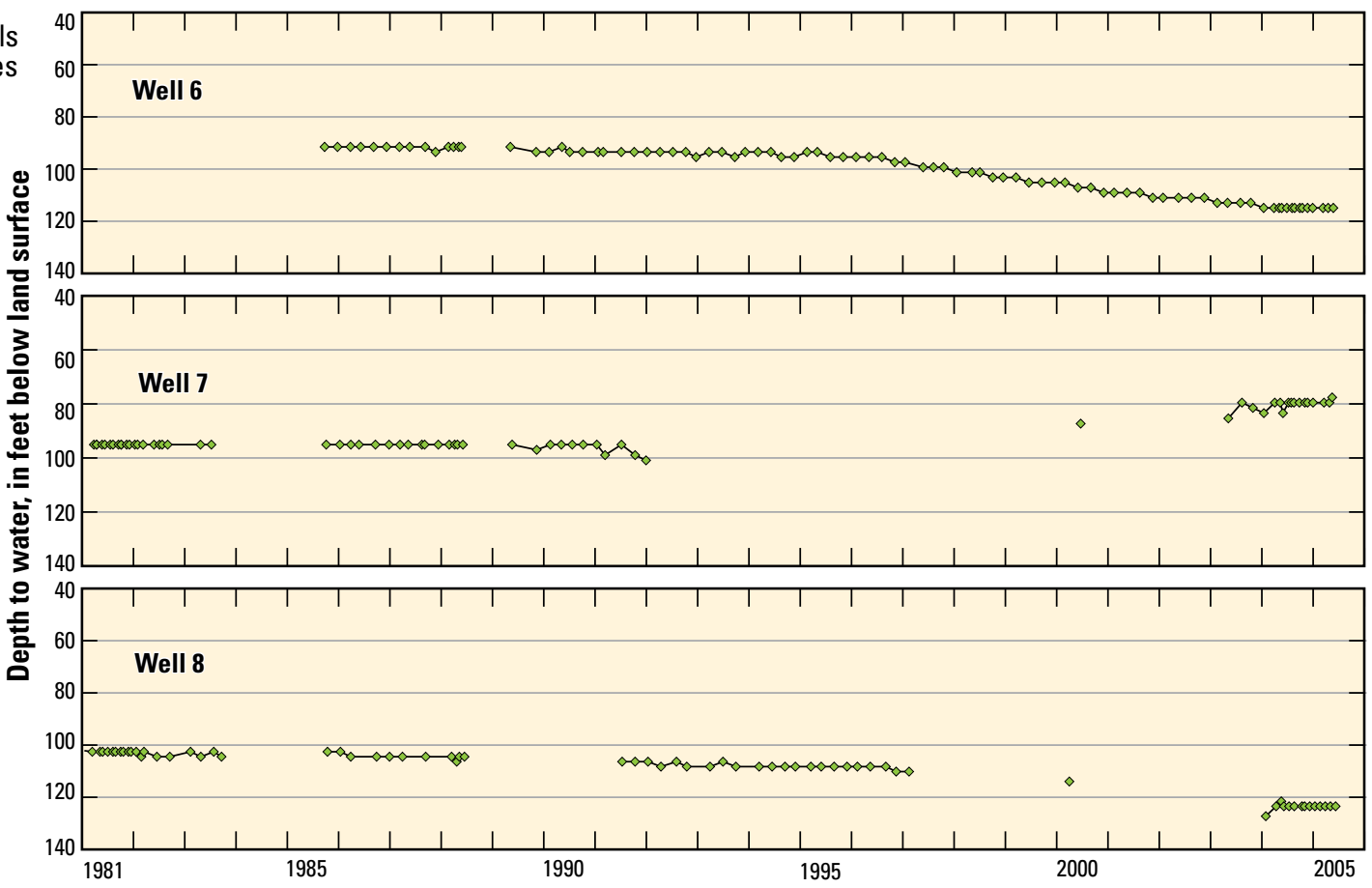

Figure 15. Water-level fluctuations,1981-2006, in $A$, wells on the western alluvial fans; $B$, shallow wells on the valley floor; $C$, deep flowing wells on the valley floor; $D$, deep irrigation wells near the valley floor; $E$, wells on the eastern side of the valley; and $F$, wells with water levels affected by changes in water use.-Continued

water levels in Fish Spring Flat (well 17) and the Ruhenstroth subdivision (well 19) declined more than $15 \mathrm{ft}$. These areas are far from irrigated lands, so recharge is limited solely to groundwater inflow from the Pine Nut Mountains.

Water levels in wells on the eastern side of Carson Valley also reflect changes in the operation of the irrigation system. Water levels within 1 mi of the Allerman \# 4 reservoir (fig. 14) declined about $20 \mathrm{ft}$ by 2005 since the use of reservoir was discontinued in 1997 (fig. $15 F$, wells 6 and 8). The declines likely resulted from the cessation of infiltration from the reservoir that maintained water levels in the surrounding area. Conversely, water levels in well 7 near the mouth of Buckeye Creek (fig. $15 F$ ) rose about $20 \mathrm{ft}$ by 2005 , likely as a result of infiltration losses from the Buckeye effluent reservoir (fig. 14) that was constructed in the 1990s $1 \mathrm{mi}$ to the northeast. 


\section{Water Budget}

Inflows and outflows to Carson Valley can be summarized in a water budget using the following equation:

$$
\begin{gathered}
\text { Precip }_{v f}+\text { Stream }_{\text {in }}+M F_{\text {rch }}+E f f+G W_{\text {in }}= \\
E T_{v f}+\text { Stream }_{\text {out }}+\text { Pump }_{\text {net }}
\end{gathered}
$$

where

$$
\begin{aligned}
& \text { Precip }_{v f} \quad \text { is precipitation on the valley floor }\left[\mathrm{L}^{3} / \mathrm{T}\right] \text {; } \\
& \text { Stream }_{\text {in }} \text { is flow in the tributaries to the Carson River } \\
& \text { entering the valley (including perennial } \\
& \text { flow from the Carson Range) }\left[\mathrm{L}^{3} / \mathrm{T}\right] \text {; } \\
& M F_{r c h} \quad \text { is mountain-front recharge (including } \\
& \text { perennial flow from the Pine Nut } \\
& \text { Mountains and ephemeral flow from } \\
& \text { both the Carson Range and the Pine Nut } \\
& \text { Mountains) }\left[\mathrm{L}^{3} / \mathrm{T}\right] \text {; }
\end{aligned}
$$

Components of the annual water budget for Carson Valley have been estimated by previous studies (Maurer and Berger, 1997; Maurer and others, 2004; Maurer and Halford, 2004; Maurer and others, 2004; Maurer and Berger, 2007; Jeton and Maurer, 2007). Annual inflows and outflows listed in table 3 and shown in figure 16 are estimates compiled for a 15 -year (yr) period (1990-2005) when precipitation was typically below average (fig. 3). The largest components of the budget are inflow of the Carson River (East Fork and West Fork) to the valley (329,000 acre-ft or 74 percent) and outflow of the Carson River from the valley (278,000 acre-ft or 62.6 percent). The net loss in downstream flow in the Carson River within Carson Valley is 51,000 acre-ft. Inflows from precipitation on the valley floor and imported wastewater from the Lake Tahoe basin account for 10.8 percent of the budget, whereas mountain-front recharge from the Carson Range and the Pine Nut Mountains provide 8.1 percent. Evapotranspiration from phreatophytes and irrigated fields on the valley floor accounts for 32.9 percent of outflow, whereas 4.6 percent of the outflow is discharged through consumptive use of pumped groundwater.

\section{Groundwater Budget}

Inflows and outflows to groundwater in Carson Valley can be summarized in a water budget using the following equation:

$$
\begin{gathered}
M F_{r c h}+\text { Valley }_{r c h}+\text { Ag }_{\text {rch }}+\text { Septic }+ \text { Stream }_{\text {infil }}+G W_{\text {in }}= \\
E T_{w t}+\text { Pump }+ \text { Stream }_{\text {disch }}
\end{gathered}
$$

where

Valley $_{r c h}$ is valley recharge from precipitation on the valley floor $\left(\right.$ Precip $\left._{v f}\right)$ and recharge from fields irrigated with wastewater and perennial flow from the Carson Range $\left[\mathrm{L}^{3} / \mathrm{T}\right]$;

$\mathrm{Ag}_{r c h}$ is agricultural recharge from irrigated fields, computed as applied irrigation water minus losses through return flows and crop ET $\left[\mathrm{L}^{3} / \mathrm{T}\right]$;

Septic is septic-tank discharge $\left[\mathrm{L}^{3} / \mathrm{T}\right]$;

Stream $_{\text {infl }}$ is infiltration of streamflow from the Carson River and its tributaries and the irrigation system to groundwater $\left[\mathrm{L}^{3 /} \mathrm{T}\right]$;

$E T_{w t}$ is evapotranspiration from the water table on the valley floor $\left[\mathrm{L}^{3} / \mathrm{T}\right]$;

Pump is total pumping of groundwater $\left[\mathrm{L}^{3} / \mathrm{T}\right]$; and Stream $_{\text {disch }}$ is groundwater discharge to the Carson River, its tributaries, and the irrigation system $\left[\mathrm{L}^{3} / \mathrm{T}\right]$.

Components of the groundwater budget for the Carson Valley (table 4) were either specified in or computed by the groundwater-flow model. Precipitation becomes groundwater recharge only in vegetated areas on the valley floor where the water table is shallow and during months when precipitation exceeds evapotranspiration. A portion of irrigation water is assumed lost through return flow to irrigation ditches and then further reduced by subtracting crop evapotranspiration losses (fig. 17A). The remaining irrigation water (if any) is assumed to infiltrate to the water table beneath the irrigated fields. Mountain-front recharge from watersheds in the Carson Range and Pine Nut Mountains was estimated from PRMS simulation results discussed previously and then adjusted during model calibration. Valley recharge is specified in the model and defined separately from agricultural recharge, which is computed based on volumes of streamflow diverted for irrigation. Infiltration of streamflow to groundwater was computed in model simulations, whereas infiltration from septic tanks (fig. 17B) was specified as a constant rate of 21.5 cubic feet per day $\left(\mathrm{ft}^{3} / \mathrm{d} ; 0.18\right.$ acre-ft/yr) per household based on the volume of effluent treated per hook-up reported in northern Douglas County (Cathe Poole, Douglas County Utilities, written commun., 2006; Frank Johnson, Minden-Gardnerville Sanitation District, oral commun., 2006). Inflow from the Eagle Valley was computed in model simulations. 
Table 3. Mean annual water budget for Carson Valley for water years 1990 through 2005.

[ac-ft/yr; acre-feet per year]

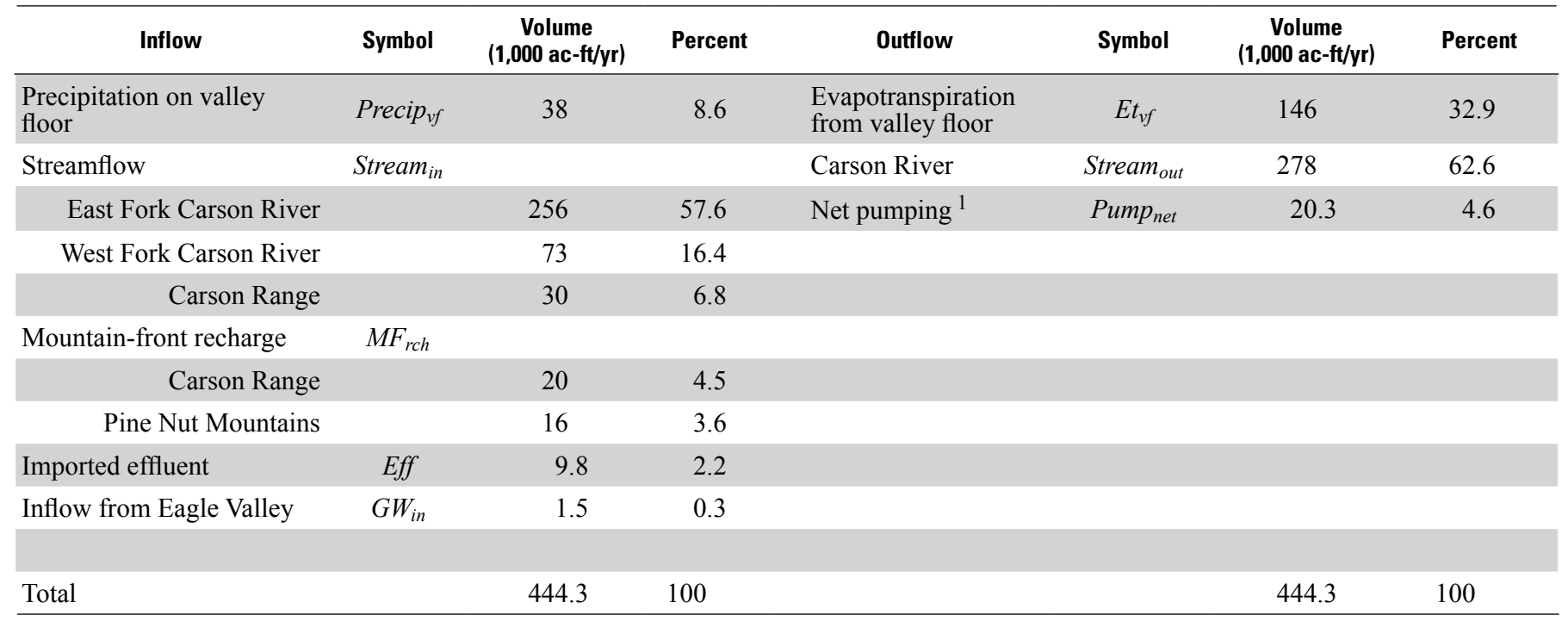

${ }^{1}$ Total pumping minus wastewater irrigation and septic discharge.

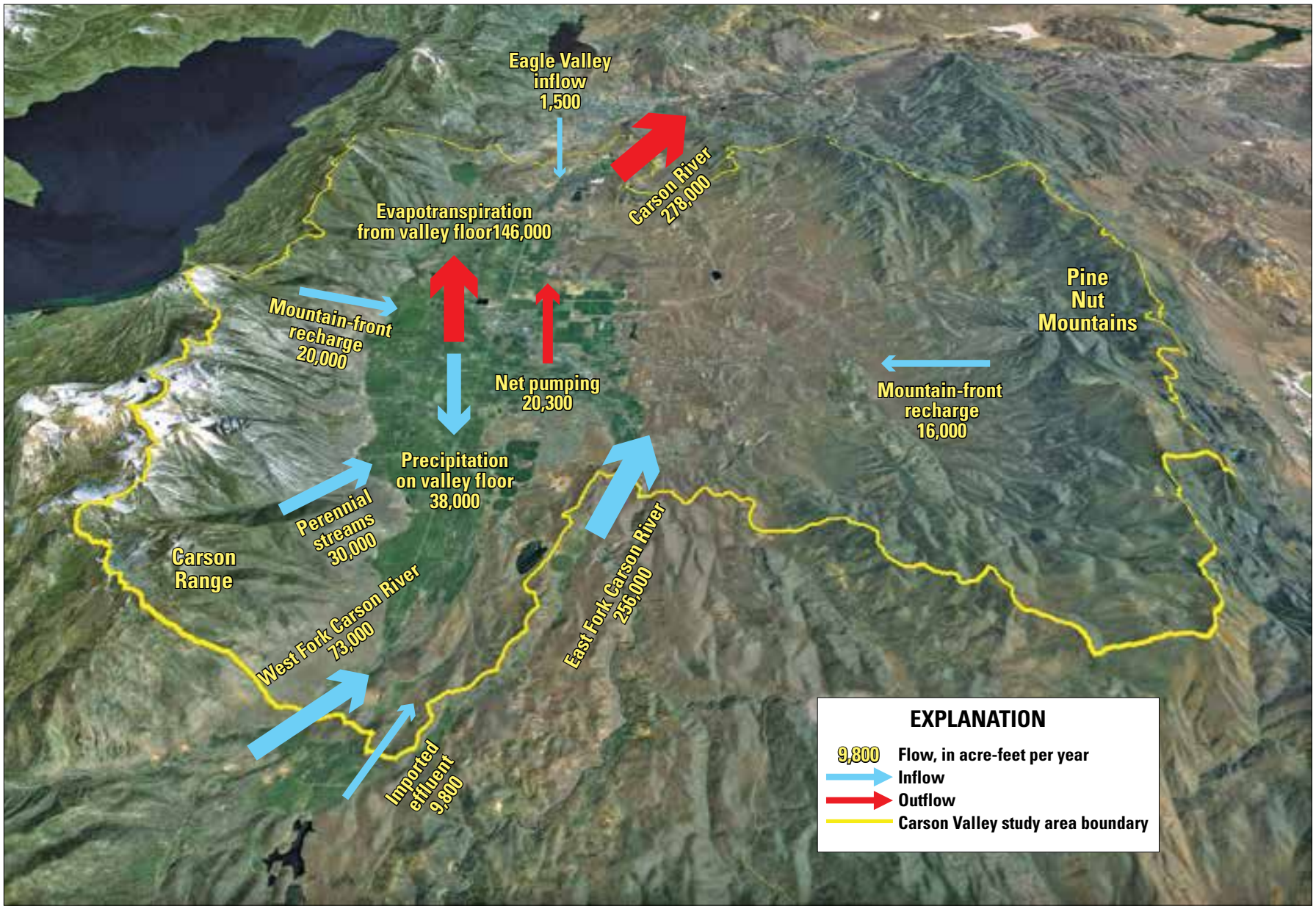

Base from U.S. Geological Survey digital data, 1:100,000, 1988

Shaded-relief from 30-meter Digital Elevation Model

Sun illumination from northwest at 30 degrees above horizon

Universal Transverse Mercator projection, zone 11

Figure 16. Components of the mean annual water budget for Carson Valley, water years 1990-2005. 
Table 4. Components of the groundwater budget for Carson Valley.

\begin{tabular}{|c|c|c|c|c|c|}
\hline Inflow & Symbol & Model value & Outflow & Symbol & Model value \\
\hline Mountain-front recharge ${ }^{1}$ & $M F_{r c h}$ & Specified & $\begin{array}{l}\text { Evapotranspiration from } \\
\text { water table }\end{array}$ & $E t_{w t}$ & computed \\
\hline Valley recharge & Valley $_{\text {rch }}$ & Specified & Pumping & Pump & specified \\
\hline Agricultural recharge & $A g_{\text {rch }}$ & Computed & Streams and ditches & Stream $_{\text {disch }}$ & computed \\
\hline \multicolumn{6}{|l|}{ Infiltration } \\
\hline Septic tanks & Septic & Specified & & & \\
\hline Inflow from Eagle Valley & $G W_{i n}$ & Computed & & & \\
\hline
\end{tabular}

${ }^{1}$ Adjusted by a factor in model calibration.

A Agricultural use Delivery ditch

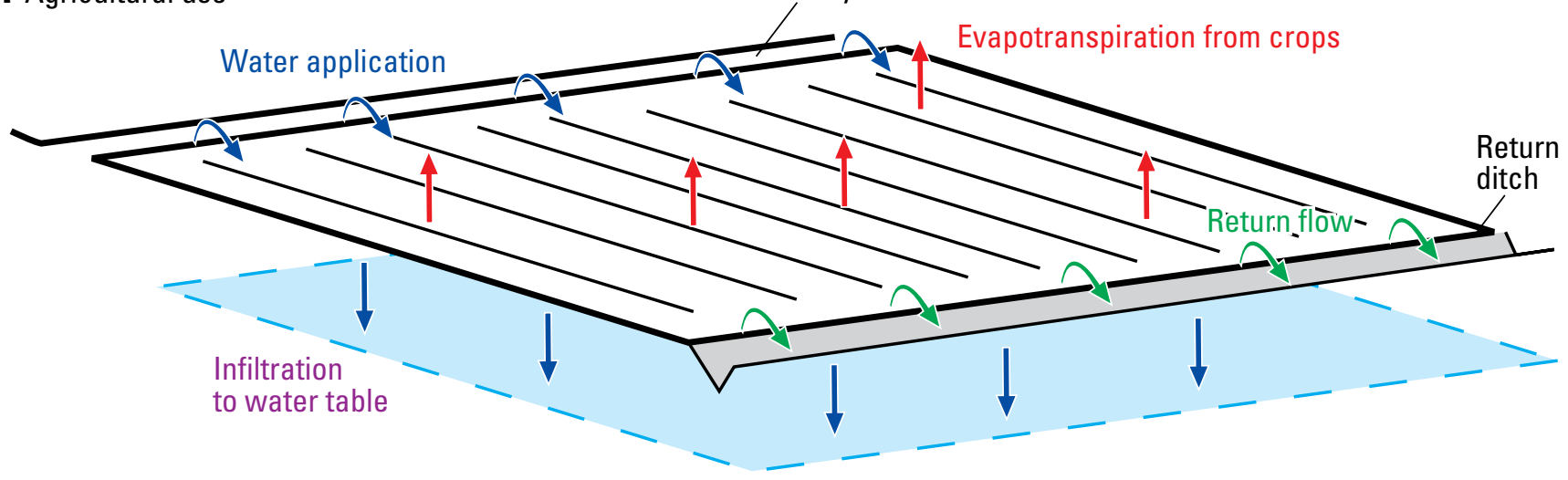

B Domestic use

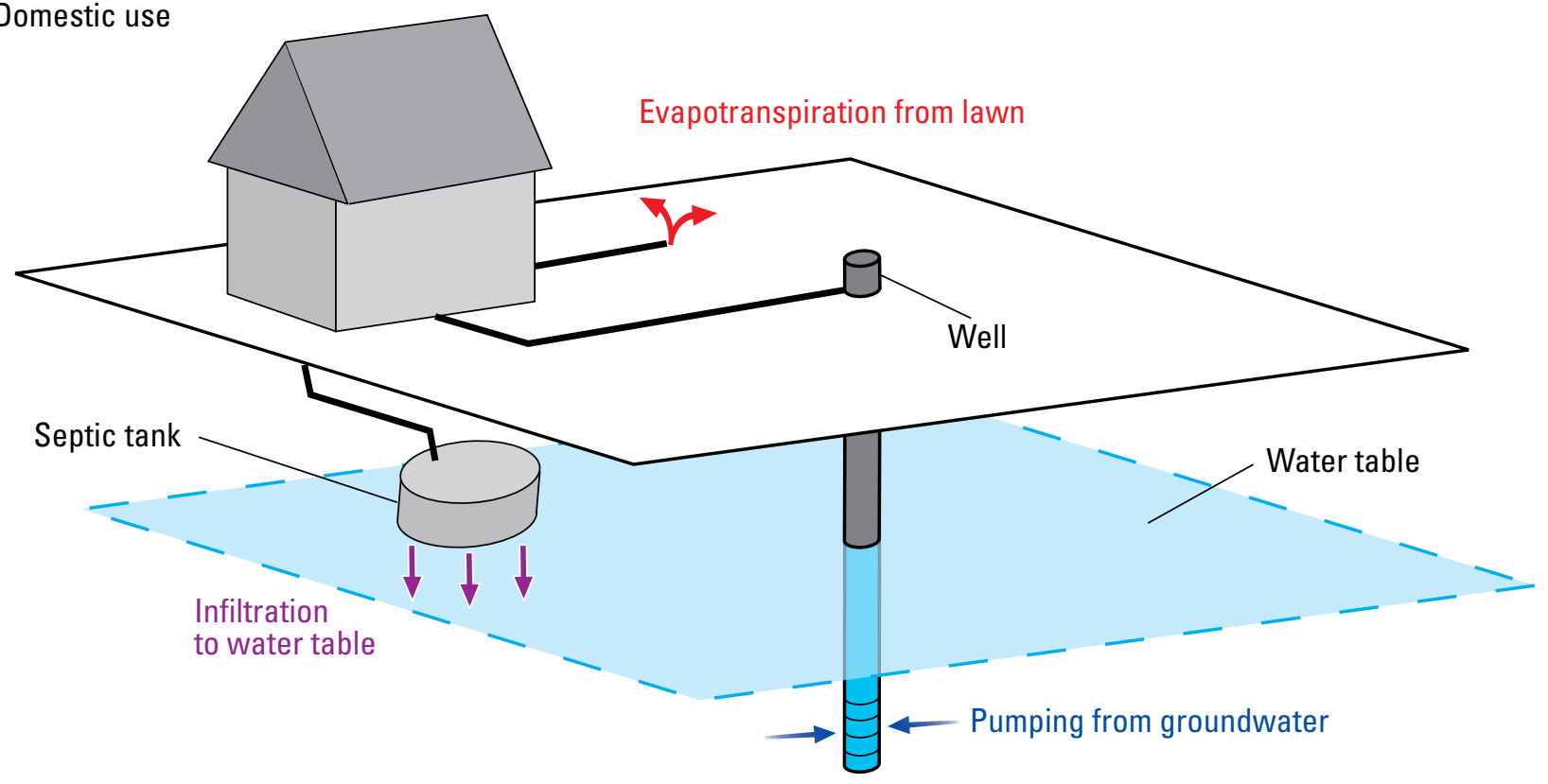

Figure 17. Inflow and outflow of water from $A$, agricultural use; $B$, domestic use. 
Discharge of groundwater in Carson Valley is assumed to occur through evapotranspiration in areas where phreatophytes grow and the depth to water is $35 \mathrm{ft}$ or less, or in irrigated areas where the depth to water is $10 \mathrm{ft}$ or less. The volume of water discharged through evapotranspiration and into streams and ditches was computed in model simulations. The volume of water pumped for domestic, municipal, agricultural, and other uses was specified in model simulations. There were 3,642 households in Carson Valley in 2005, and each household was assumed to pump $134 \mathrm{ft}^{3} / \mathrm{d}(1.12 \mathrm{acre}-\mathrm{ft} / \mathrm{yr})$ for domestic use. In addition, there were 12 agricultural and municipal wells that each pumped more than $50,000 \mathrm{ft}^{3} / \mathrm{d}$ (419 acre-ft/yr) in 2005.

\section{Groundwater-Flow Model}

Groundwater flow through Quaternary and Tertiary sediments in Carson Valley was simulated using MODFLOW-2005 (Harbaugh, 2005), a three-dimensional, numerical finite-difference groundwater-flow model. The exchange of water among groundwater, the Carson River, and the irrigation system was represented with a version of the Streamflow Routing (SFR2) package (Niswonger and Prudic, 2005) that was modified to apply diversions from the irrigation network to irrigated areas as recharge. A 35-yr transient simulation was designed and calibrated to represent historical conditions for water years 1971-2005, a period of increasing development and groundwater pumping. A steady-state period representing conditions in 1970 provided initial conditions for the transient simulation. The 35-yr transient simulation represented quarterly changes in precipitation, streamflow, pumping, and irrigation. Model results were used to quantify certain components of the groundwater budget (table 4) and the exchange between surface water and groundwater, and to depict the rate and direction of groundwater flow in Carson Valley. The calibrated model was then applied in 55-yr transient simulations (2006-60) to predict changes in groundwater levels and discharges that would result from alternative future water-use scenarios.

\section{Model Design}

The model domain covers an area of $242.8 \mathrm{mi}^{2}$ that includes the portion of the study area underlain by Quaternary and Tertiary sediments. The model domain is bounded to the west by the Carson Range and to the east by the Pine Nut Mountains (fig. 18). The southern boundary is located near where the East and West Forks of the Carson River emerge from the bedrock uplands and onto the valley floor, whereas the northern boundary coincides with the watershed divide upstream of the gage on the Carson River near Carson City NV. The model represents groundwater flow through the unconsolidated sediments with a saturated thickness that ranges from 20 to $5,000 \mathrm{ft}$. The model also represents the exchange of groundwater and surface water in the Carson River and its tributaries, and includes an approximate representation of the complex irrigation system in Carson Valley.

\section{Discretization}

The model domain is discretized using a regularly spaced grid with cells that measure $550 \mathrm{ft}$ on each side. The model grid was oriented along the north-south axis of the valley approximately parallel with the general direction of surfaceand groundwater flow in the valley, and likely parallel with relict, buried stream channels of the Carson River. The cell size was selected to be small enough to represent the exchange of water between groundwater and surface water, yet large enough for efficient numerical computation. The 35-yr simulation is divided into 140 quarterly (3-month) periods, each containing 6 time steps that ranged from 12 to 19 days.

The top surface of the model represents land-surface elevation computed from $3-\mathrm{ft}$ (ground sample distance) LiDAR data on the valley floor (BAE SYSTEMS Advanced Technologies, Inc., 2004) and a 30-ft digital elevation model in higher terrain. The bottom model boundary represents the bedrock surface mapped by gravity surveys (fig. 5). The unconsolidated sediments are divided into 10 model layers; the extents and thicknesses of model layers were chosen to conform to the assumed distribution of Quaternary and Tertiary sediments in Carson Valley (fig. 19). The top three model layers represent fluvial sediments in the center of the valley and alluvial-fan sediments to the east and west (fig. 18). The lateral extent of model layer 1 is limited to the relatively flat portion of the valley. Model layers 4 through 10 primarily represent Tertiary sediments that are exposed on the eastern side of Carson Valley and dip beneath the Quaternary sediments to the west (fig. 19). The Tertiary sediments are assumed to be displaced (down-dropped) $800 \mathrm{ft}$ west of the hypothesized Hot Springs Mountain fault, so that layers 4 through 7 represent fluvial sediments west of the fault (fig. 18). The average thickness of model layers increases from $80 \mathrm{ft}$ at the top of the model to almost $900 \mathrm{ft}$ at the bottom of the model.

\section{Boundaries}

All the lateral and bottom boundaries of the model are assumed to be no-flow (impervious to flow) with the exception of part of the northern boundary that is treated as head-dependent flow (fig. 18). This boundary represents underflow $\left(G W_{i n}\right)$ through basin-fill sediments from the Eagle Valley (fig. 1) and was assigned hydraulic-head altitudes based on water levels measured in 2006 in seven wells that straddle the boundary.

\section{Inflows}

Valley recharge derived from precipitation on the valley floor $\left(\right.$ Precip $\left._{v f}\right)$ and the application of irrigation water $\left(A g_{r c h}\right)$ is represented as specified flow (recharge) in the top model layer. Precipitation is assumed to occur throughout the areas covered 


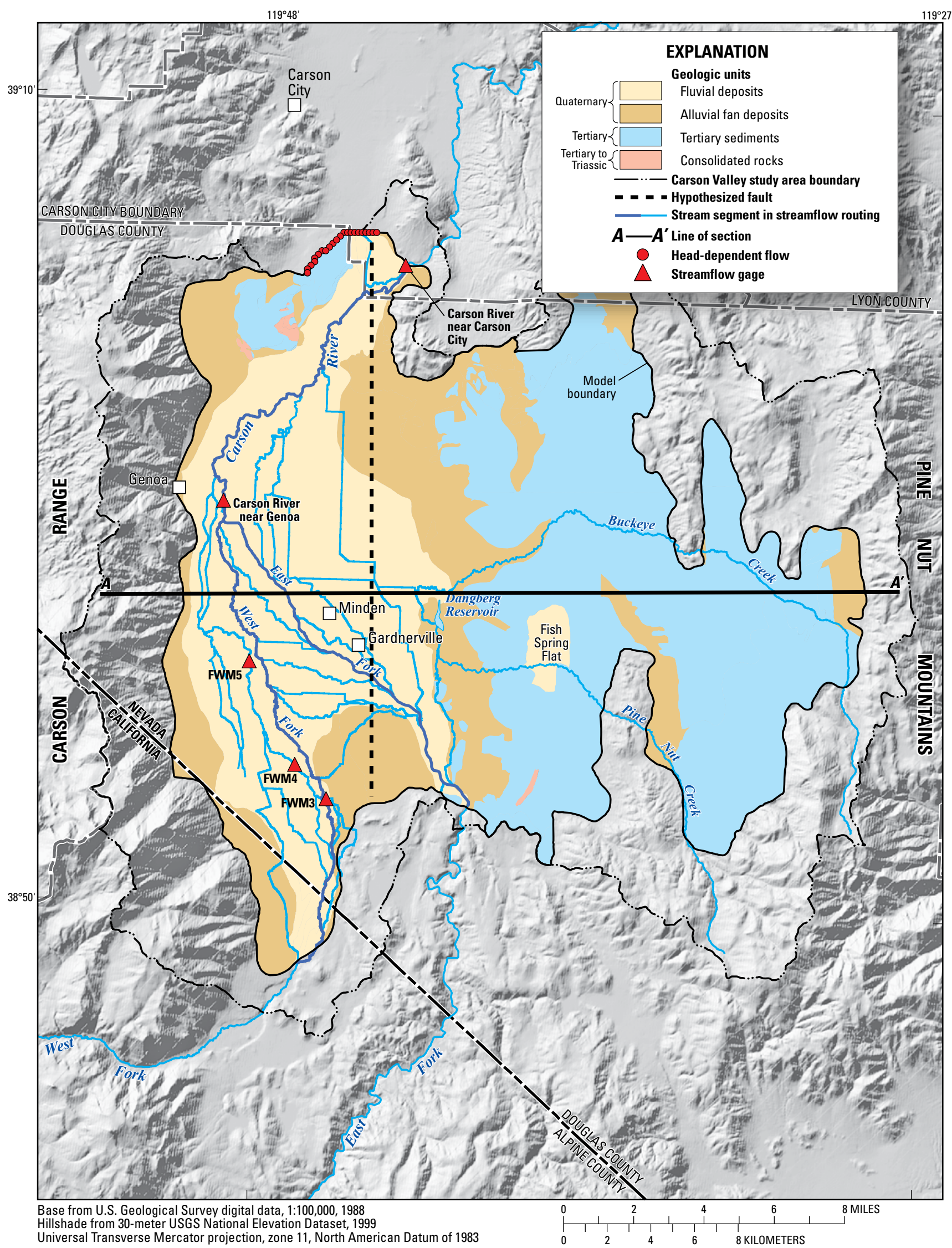

Figure 18. Model domain and distribution of Quaternary and Tertiary sediments in Carson Valley groundwater model and location of hypothesized Hot Springs Fault. 

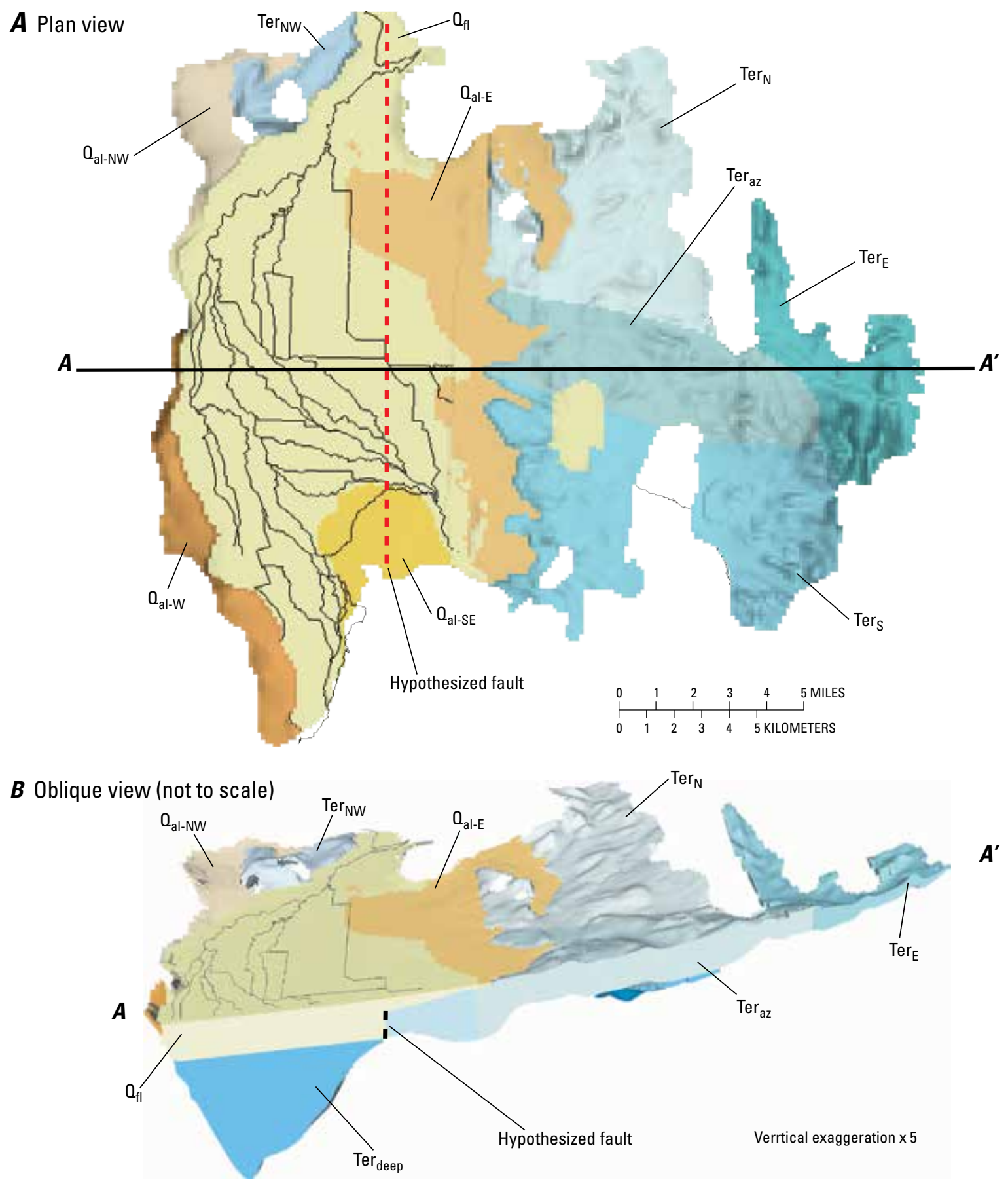

Figure 19. Assumed lateral and vertical distribution of Quaternary and Tertiary sediments. Labels associated with geologic units refer to parameters listed in table 7 .

by phreatophytes or irrigated fields (fig. 20) and is specified quarterly during the 35 -yr simulation period using the distribution of mean annual precipitation estimated by Maurer and Halford (2004, p. 35) for water years 1990-2005. Quarterly precipitation in each water year of the 35 -yr period is based on measured daily precipitation at Minden, Nevada.

Irrigation water is applied in irrigated fields using water diverted from the 12 perennial streams that drain the Carson Range, application of effluent wastewater, and diversions from the Carson River and the adjoining irrigation system (discussed further in the section describing streamflow routing). The volume of irrigation water is reduced by 30 percent to account for return flow that is assumed to remain in the irrigation system. The resulting volume of applied water is then reduced by factors of 70 and 80 percent to account for crop ET losses in the spring and summer quarters, respectively. The remaining volume is then allocated as specified flow (recharge) equally among the model cells that represent the irrigated parcel. 


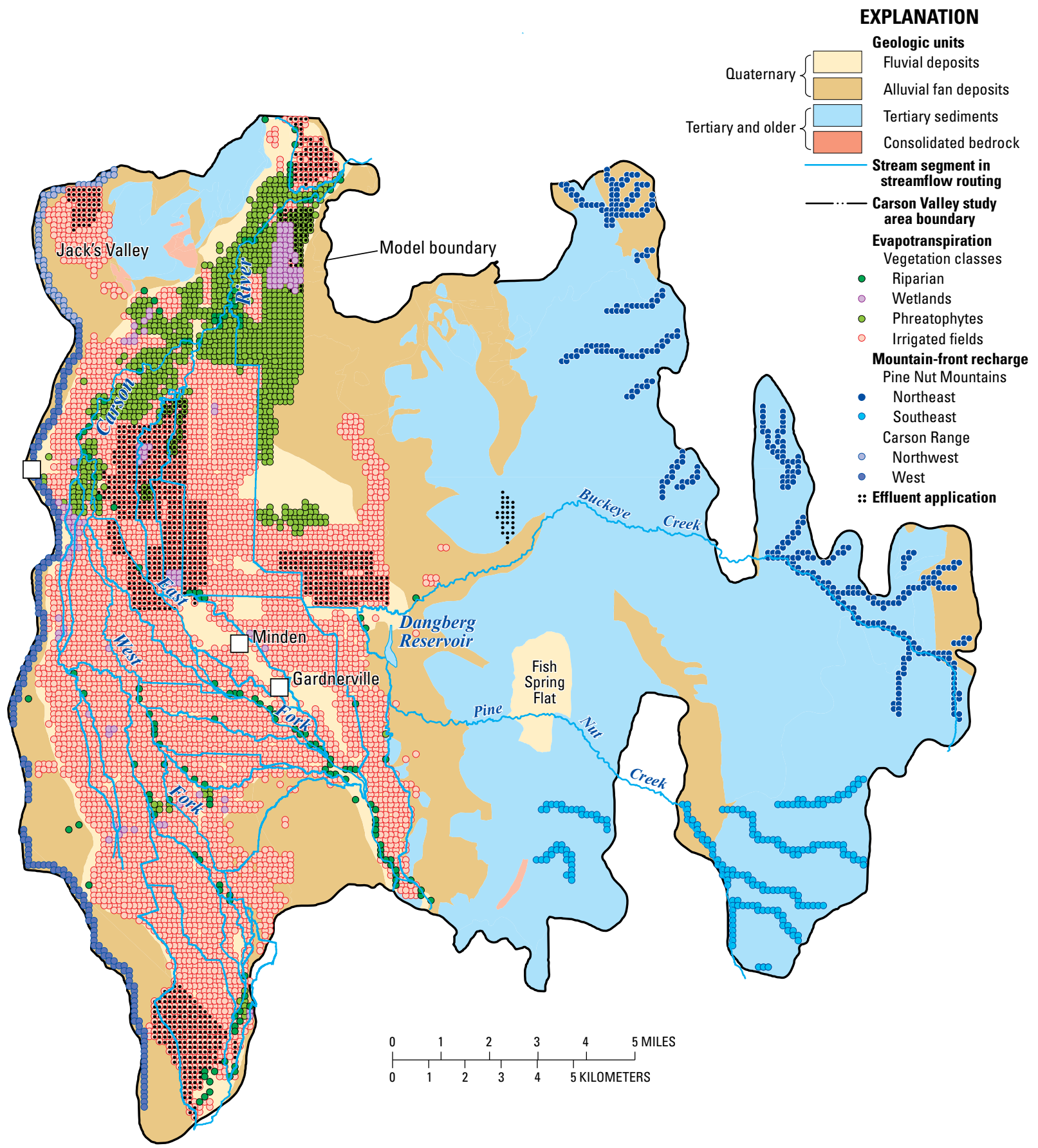

Figure 20. Distribution of mountain-front recharge, effluent application, and evapotranspiration in Carson Valley groundwater model. 
Irrigation water is applied to water-rights areas near the foot of the Carson Range (fig. 7) in the irrigation season based on runoff from the 12 perennial streams that drain the Carson Range computed by the PRMS watershed models discussed previously. Recharge from effluent wastewater is represented in the irrigation season based on the reported annual volume permitted by the Nevada Department of Environmental Protection and reports from effluent suppliers and end users (Hal Bird, South Tahoe Public Utility District, written commun., 2005, Kelvin Ikehara; Douglas County Sewer Improvement District No. 1, written commun., 2010; Frank Johnson, Minden Gardnerville Sanitation District, written commun., 2010; Jim Usher, Bently Agrodynamics Ranch Manager, oral commun., 2010).

Mountain-front recharge $\left(M F_{r c h}\right)$ is represented through specified flows (simulated as injection wells) to cells in the layer below the top active layer. The cells are located along the foot of the Carson Range on the western side of the valley and along stream channels draining the Pine Nut Mountains on the eastern side of the valley (fig. 20). Recharge volume was based on daily values estimated by PRMS watershed models discussed previously for the period 1978-2005. Annual recharge volumes for the period 1970-77 were calculated from the measured precipitation at Minden and a relation between recharge and precipitation derived for the period 1978-2005. The PRMS recharge values were adjusted in model calibration in four areas: the western alluvial fans and Jacks Valley along the Carson Range (west and northwest areas), and the northern and southern zones along the Pine Nut Mountains (northeast and southeast areas).

Infiltration of septic-tank discharges (Septic) were represented through specified flows (simulated as injection wells) in the top active model layer. The number of recharge cells specified to represent septic-tank discharge increased from about 450 in 1970 to almost 4,200 in 2005. The recharge cells were located from parcels mapped in a GIS database by Douglas County (Dawn Patterson, Douglas County MultiAgency Geographic Information Center [MAGIC], written commun., 2006). Infiltration of streamflow from the Carson River and its tributaries and the irrigation system to groundwater $\left(\right.$ Stream $\left._{\text {infil }}\right)$ is discussed further in the section describing streamflow routing.

\section{Outflows}

Evapotranspiration (ET) from groundwater is represented as a head-dependent boundary in the top model layer for four vegetation classes: irrigated pasture grasses and alfalfa, native phreatophytes (mainly rabbit brush and greasewood), wetlands, and riparian willows. The rate of ET loss per unit surface area $Q_{E T}$ was computed in transient simulations using a depth-dependent function:

$$
Q_{E T}=\frac{E T_{\max }}{d_{E T}}\left(H-\left(L S-d_{E T}\right)\right)
$$

where

$$
\begin{aligned}
E T_{\max } & \text { is maximum ET rate }[\mathrm{L} / \mathrm{T}], \\
d_{E T} & \text { is extinction depth below which no ET occurs } \\
& \text { [L], } \\
H & \text { is hydraulic head }[\mathrm{L}], \text { and } \\
L S & \text { is land surface altitude }[\mathrm{L}] .
\end{aligned}
$$

The maximum ET rates $\left(E T_{\max }\right)$ are specified quarterly for irrigated crops, phreatophytes, and wetlands based on monthly rates reported by Maurer and others (2006, p. 22). ET rates for riparian willows are based on monthly rates estimated for willows in the Walker River basin about 40 mi east of Carson Valley (Allander and others, 2009, p. 35). The annual $E T_{\max }$ rates are $3.0 \mathrm{ft} / \mathrm{yr}$ for irrigated alfalfa and pasture grasses, $1.9 \mathrm{ft} / \mathrm{yr}$ for native phreatophytes, $4.4 \mathrm{ft} / \mathrm{yr}$ for wetlands, and $3.8 \mathrm{ft} / \mathrm{yr}$ for riparian willows. The extinction depth for phreatophytes, wetlands, and riparian willows is specified as $30 \mathrm{ft}$, whereas the extinction depth for irrigated alfalfa and pasture grasses is specified as $10 \mathrm{ft}$.

Pumping of groundwater for municipal, domestic, irrigation, and other water supplies is represented by specified flow boundaries (discharge wells). The number of wells increases from about 520 in 1970 to almost 4,000 in 2005. About 90 percent of the wells supply water for domestic use. Altitudes of well screens were used to assign the wells to model layers, but this information is available for less than 10 percent of the wells, mainly those that are used for municipal or irrigation water supply. Depths for other remaining wells were assigned $150 \mathrm{ft}$ below land surface for domestic wells and $300 \mathrm{ft}$ below land surface for municipal, industrial, and irrigation wells. The infiltration of water from conveyance losses associated with municipal supplies is assumed to be negligible in model simulations. Water pumped for irrigation at a fish hatchery is discharged to the irrigation system and is simulated through streamflow routing described in the following section.

Estimates of annual pumpage for water years 1970-80 (Maurer and others, 2009, p. 34-39) are based on the number of wells in use each year for municipal, domestic, irrigation, and other supplies. Estimates of annual pumpage for water years 1981-86 (Maurer, 1986, p. 62-63; Berger, 1987, p. 14; Berger, 1990, p. 9) are based on reports from water purveyors for municipal supply and power usage/pump efficiency data for irrigation supply. Estimates of annual pumping for water years 1987-2005 are based on NDWR pumping inventories as described by Clark (2006). Annual pumpage volumes are apportioned quarterly based on reported monthly metered pumping for municipal supply and power usage for irrigation supply. Quarterly pumping volumes (as a percentage of annual volume) for municipal supplies in each water year are $13,7,31$, and 49 percent for the fall, winter, spring and summer quarters, respectively. The quarterly volume of domestic pumping is assumed to follow the same pattern. Quarterly pumping volumes for irrigation supplies for the same four quarters are $7,0,9$, and 84 percent. 


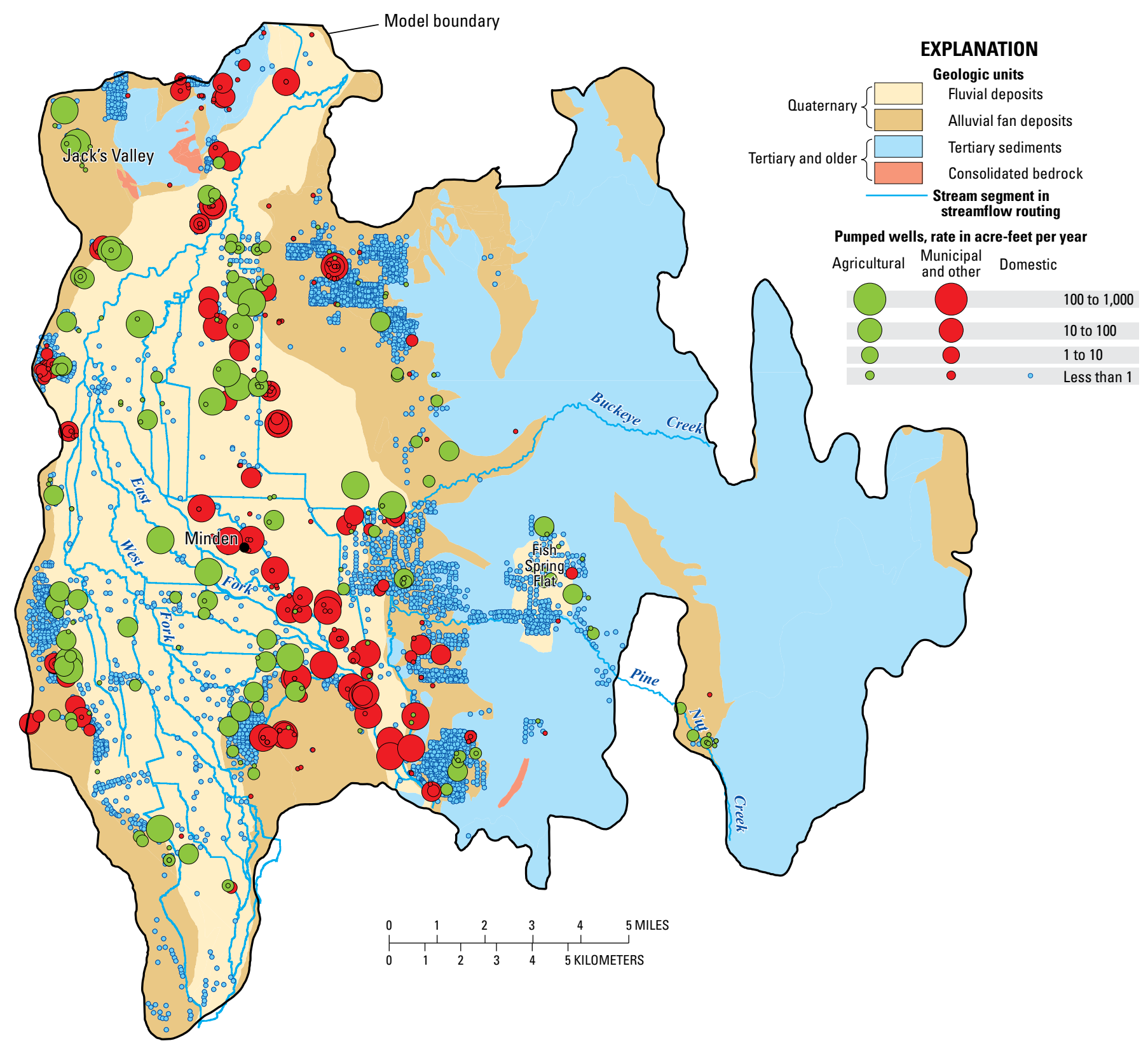

Figure 21. Location of municipal, domestic, and irrigation supply wells in Carson Valley groundwater model.

The locations of the principal municipal supply wells were determined from Global Positioning Satellite (GPS) data collected by NDWR, Douglas County, and water purveyors (fig. 21). The locations of irrigation supply wells were determined from the township, range, section, and quarter location on water-right permits listed in NDWR reports, and then adjusted using historical maps on file at the USGS office in Carson City, Nevada. Domestic wells were located using mapped parcels supplied by Douglas County (Dawn Patterson, Douglas County MAGIC, written commun., 2006). The parcel map also provides the dates when domestic wells and septic tanks were installed.

\section{Streamflow Routing}

The exchange of water between groundwater, the Carson River, and the adjoining irrigation system was represented with the Streamflow Routing (SFR2) package (Niswonger and Prudic, 2005). This head-dependent boundary allows groundwater discharge where stream stage is higher than the water table (losing reaches), stream infiltration to groundwater where stream stage is lower than the water table (gaining reaches) and the diversion of water for irrigation. The volume of water exchanged between the groundwater and surface-water systems is calculated on a cell by cell basis as the difference in head between stream stage and the water table multiplied by the streambed conductance. The SFR2 package accounts 
for water that enters and flows through the irrigation system using Manning's equation to compute the stream depth at each location within the network as a function of flow and channel geometry (Niswonger and Prudic, 2005). The SFR2 package was modified for the groundwater model of Carson Valley to apply diversions from the irrigation system to irrigated areas as recharge, as discussed in the appendix 1 . The volume of the diverted water is reduced by two factors that account for return flow and crop ET losses (as was done for irrigation water derived from water-rights areas and wastewater); the remainder is specified as recharge to groundwater.

The SFR2 boundary represents the Carson River and its tributaries, and 25 canals, ditches, and sloughs within the irrigation system as 432 stream segments that comprise 2,656 reaches (model cells; fig. 18). The model also represents 520 diversions for irrigation. An 8-point channel with a V-shaped bottom is defined for each stream reach; this configuration provides a smooth transition of stream depths from high to low flow and facilitates numerical convergence. The SFR2 boundary requires definition of a conductance term $C$ :

$$
C=\frac{K_{s t r} L W}{l}
$$

where

$$
\begin{array}{cl}
K_{s t r} & \text { is hydraulic conductivity of the streambed [L/T], } \\
L & \text { is length of stream reach [L] } \\
W & \text { is width of stream reach [L], and } \\
l & \text { is thickness of streambed [L]. }
\end{array}
$$

The quantity of flow exchanged between groundwater and streamflow in a model cell is the stream conductance times the difference between the groundwater level and stream stage.

The widths of the East and West Forks and the main stem of the Carson River range from 30 to $140 \mathrm{ft}$, whereas widths of channels in the irrigation system range from 17 to $60 \mathrm{ft}$, as determined from the LiDAR data. Streambed thickness was assigned an arbitrary value of $1 \mathrm{ft}$. The channel bottom elevations were assumed to be $6 \mathrm{ft}$ and $3 \mathrm{ft}$ below land surface for natural and manmade channels, respectively. The stream segments were divided into 12 groups on the basis of location within the valley and the type of underlying sediment (table 5). The $K_{s t r}$ values for six groups were estimated through model calibration. The $K_{s t r}$ values for the remaining six groups were computed from these estimated values based on location and stream width.

Inflows from the East and West Forks of the Carson River and Clear Creek are specified for each period in the 35-year simulation based on flow measured at USGS gages. Because of the short period of record for available streamflow data, inflow from Indian Creek is specified as 2 percent of the flow in the East Fork Carson River. Inflows to Pine Nut Creek and Buckeye Creek for the 35-yr period were from gaged data for water years 1981-97 and from runoff computed using the PRMS watershed models described earlier for the remaining years. Although the West Fork Carson River gage is located 2 mi upstream of the model boundary, the exchange of water between the channel and groundwater is assumed
Table 5. Groups of stream segments for which streambed

\begin{tabular}{|c|c|c|}
\hline & Center & \\
\hline & & Rocky Slough \\
\hline & & Edna Wilslef Ditch \\
\hline & North & \\
\hline & & Heyburn Ditch \\
\hline & East & \\
\hline & & Allerman Canal \\
\hline & & Virginia Ditch \\
\hline & South & \\
\hline & & Dressler Ditch \\
\hline & & Company Ditch \\
\hline & & Fredericksburg Ditch \\
\hline & & Falke and Tillman Ditch \\
\hline & & Jones Company Ditch \\
\hline & & Thran Ditch \\
\hline \multicolumn{3}{|l|}{ Lowland } \\
\hline & Center & \\
\hline & & Heise Company Ditch \\
\hline & & Home Slough \\
\hline & & Henningston Slough \\
\hline & & Saint Louis Straight Ditch \\
\hline & North & \\
\hline & & Middle Ditch \\
\hline & & Rosser Ditch \\
\hline & & Williams Slough \\
\hline & East & \\
\hline & & Cottonwood Slough \\
\hline & & Martin Slough \\
\hline & & Poleline Ditch \\
\hline & West & \\
\hline & & Brockliss Slough \\
\hline & & Fredericksburg Ditch \\
\hline & & Johnson Slough \\
\hline & & Park and Bull Slough \\
\hline
\end{tabular}
hydraulic conductivity was specified.

[Values were estimated for groups that are shaded]

\begin{tabular}{cl}
\hline \multicolumn{1}{c}{ Hydraulic-conductivity group } & \multicolumn{1}{c}{ Stream segment } \\
\hline Carson River & \\
Main stem & Carson River downstream of Genoa \\
East Fork & Carson River East Fork \\
West Fork & Carson River West Fork \\
& \\
Creeks & Buckeye Creek \\
& Pine Nut Creek \\
& Clear Creek \\
\hline
\end{tabular}

$$
\begin{aligned}
& \text { Irrigation ditches } \\
& \text { Upland }
\end{aligned}
$$


to be negligible between the gage and the model boundary. Although diversions from the channel do occur along this reach, most of the diverted water is assumed to return to the channel upstream of the model boundary (Maurer and Berger, 2007, p. 21).

The volume of streamflow diverted from the East and West Forks of the Carson River to nine ditches during each quarter of the year are approximate and determined from monthly flows recorded by the FWM from 1984 to 2005. Diversions in water years prior to 1984 were estimated by comparing the mean annual flow measured in the East Fork and the West Fork of the Carson River with recorded ditch flows from 1984 to 2005 to determine the appropriate monthly allocation. Streamflow diversions to 18 ditches without recorded flow are based on estimates of flow capacity reported by Unger (2006, p. 86, 139). The ditches are assumed to flow at 75 percent of capacity during the irrigation season until the flow in the East Fork Carson River falls below 200 cubic feet per second $\left(\mathrm{ft}^{3} / \mathrm{s}\right)$ and flow in the West Fork Carson River falls below $180 \mathrm{ft}^{3} / \mathrm{s}$. Once streamflow drops below these thresholds, diversions to ditches are regulated by the FWM and rotated periodically so that the ditches are assumed to flow at 50 percent of capacity (Hess and Taylor,1999, p. 16,17). Little or no flow enters the ditches during the non-growing season when irrigation is not applied.

Irrigated parcels that receive diversions from the irrigation system are listed in the Alpine Decree and mapped in a GIS database prepared for the U.S. Fish and Wildlife Service (Andrew Stroud, History Mapping Services, digital dataset, August 20,2008). Recharge is applied to model cells that correspond to the irrigated parcels during the irrigation season of each water year. The volume of water diverted for irrigation is reduced by 30 percent to account for return flow that is assumed to remain in the irrigation system. The resulting volume of applied water is then reduced by factors of 70 and 80 percent to account for crop ET losses in the spring and summer quarters, respectively. The remaining volume is then allocated as recharge equally among the model cells that represent the irrigated parcel.

The volume of water diverted for each parcel is based on the water right granted by the Alpine Decree, but the volume is limited by the available flow within the source segment of the irrigation system. The SFR2 package routes streamflow through the irrigation system from upstream segments to downstream segments. The supplied diversion of irrigation water, therefore, reduces the remaining flow in the irrigation system. If the flow in the source segment is less than the water right, then the available flow in the source segment is diverted and the segment is dewatered. Flow diversions were specified as a percentage of flow rather than a volume of flow at seven stream junctions to ensure that flow was available in downstream segments. Diversions from the irrigation system to irrigated parcels are computed in order by the priority of each water right, which is based on its age. Some water rights were transferred during the 35 -yr simulation period as development removed agricultural land from irrigation. The water-rights database maintained by the Nevada Division of Water Resources (http://water.nv.gov/waterrights) was used to track the largest transfers and to adjust allocations of diverted water in the simulation. In some cases, however, the history of water-right transfers is difficult to determine precisely, so the simulation represents an approximation of the actual changes in water use over the period.

\section{Hydraulic Properties}

\section{Hydraulic Conductivity}

Horizontal hydraulic-conductivity values $\left(K_{x y}\right)$ for Quaternary sediments were computed from the kriged distribution of log transmissivity presented earlier (fig. 12), assuming a saturated thickness that was equivalent to the median depth of wells included in the kriged interpolation (200 ft). The Quaternary sediments were divided into five zones that included the four alluvial-fan deposits $\left(\mathrm{Q}_{\mathrm{al}-\mathrm{NW}}, \mathrm{Q}_{\mathrm{al}-\mathrm{W}}, \mathrm{Q}_{\mathrm{al}-\mathrm{E}}, \mathrm{Q}_{\mathrm{al}-\mathrm{SE}}\right)$ as well as the fluvial sediments $\left(Q_{f} ;\right.$ fig. 19). Factors were estimated through model calibration for each of the five zones to adjust the magnitude of horizontal hydraulic-conductivity values within each zone. Vertical hydraulic-conductivity values $\left(K_{z}\right)$ were computed using three vertical-anisotropy values $\left(K_{x y} / K_{z}\right)$ estimated through model calibration for the eastern and western alluvial fans and the fluvial sediments. Horizontal anisotropy $\left(K_{x} / K_{y}\right)$ was also specified for the western alluvial fan to represent preferred flow paths in the direction of deposition from the front of the Carson Range eastward to Carson Valley. The western alluvial fan is composed of several coalescing fan deposits. Groundwater flows mainly through transmissive layers within each fan deposit from the mountain front toward the valley, and there is probably little hydraulic connection between adjacent fans. A horizontal-anisotropy value of 5 was specified to increase simulated flow from west to east and limit flow from higher elevations in the south towards lower elevations in the north.

Horizontal hydraulic-conductivity values for Tertiary sediments were estimated through model calibration for five zones delineated on the basis of sections described by Muntean (2001). Tertiary sediments in the eastern part of Carson Valley were divided into four zones: the accommodation zone $\left(\mathrm{Ter}_{\mathrm{az}}\right)$ and areas to the north, and to the south and east $\left(\operatorname{Ter}_{\mathrm{N}}\right.$, $\mathrm{Ter}_{\mathrm{S}}$, and $\mathrm{Ter}_{\mathrm{E}}$; fig. 19). An additional zone was defined for Tertiary sediments in the northwest near Jacks Valley $\left(\right.$ Ter $\left._{\mathrm{NW}}\right)$. The $K_{x y}$ values were estimated for the northern, northwestern, and southern zones, while the $K_{x y}$ values for accommodation and eastern zones were assumed to be twice and one-half, respectively, the northern $K_{x y}$ value on the basis of lithology. A sixth zone was delineated for buried sediments in the deeper parts of the basin beneath the Quaternary sediments $\left(\right.$ Ter $\left._{\text {deep }}\right)$ and assigned a $K_{x y}$ value of 1 foot per day (ft/d). Two verticalanisotropy values were estimated through model calibration for the Tertiary sediments. One $K_{x y} / K_{z}$ value was estimated for the accommodation and southern zones, and a second $K_{x y} / K_{z}$ value was estimated for the remaining zones. 
The aquifer system was assumed to be confined to facilitate the numerical convergence of the solution of the groundwater-flow equation. This assumption implies that the transmissivity of model layers that intersect the simulated water table is fixed during the transient simulation and is not a function of simulated head. The top model boundary was specified as the land surface, so the hydraulic conductivity was multiplied by a factor ( Sat $_{\text {factor }}$ ) to account for partial saturation of model layers that intersect the water table:

$$
S a t_{\text {factor }}=\frac{\text { head }_{\text {sim }}-\text { bottom }_{\text {layer }}}{\text { thick }_{\text {laver }}}
$$

where

head $_{\text {sim }}$ is the head computed by a prior simulation,

bottom $_{\text {layer }}$ is the elevation of the bottom of the model layer, and

thick $_{\text {layer }}$ is the layer thickness.

Sat $t_{\text {factor }}$ was set to $0.1 \mathrm{x}$ thick layer $_{\text {in }}$ areas where the simulated head was below the bottom of the model layer.

This modification was necessary because MODFLOW uses the full layer thickness to compute transmissivity for confined model layers. The simulated head is a function of Sat factor, so an iterative procedure was used to update $S a t_{\text {factor }}$ values. This entailed repetitively running the calibrated model with updated $S a t_{\text {factor }}$ values to compute a new head distribution, and then recalculating Sat $_{\text {factor }}$ until the change in model error was less than 0.2 percent. The assumption of confined conditions was later shown to have had little effect on model results, as discussed in the later section on "Model Uncertainty."

In many geologic settings, hydraulic conductivity is known to decrease systematically with depth. A power function similar to that applied to the Death Valley area in Nevada and California by Belcher (2004) is used to calculate the decrease in horizontal hydraulic-conductivity below a threshold depth D:

$$
K_{\text {depth }}=K_{x y} 10^{-\lambda d}
$$

where

$$
\begin{array}{cl}
K_{\text {depth }} & \text { is the horizontal hydraulic-conductivity }[\mathrm{L} / \mathrm{T}] \\
& \text { at depth } d[\mathrm{~L}] \text { below } D, \text { and } \\
\lambda & \text { is a decay factor }\left[\mathrm{L}^{-1}\right] .
\end{array}
$$

The threshold depth $D$ and depth-decay factor $\lambda$ specified for Quaternary sediments were $500 \mathrm{ft}$ and $5 \times 10^{-4} \mathrm{ft}^{-1}$, respectively, whereas the corresponding values for the Tertiary sediments were specified as $200 \mathrm{ft}$ and $8 \times 10^{-4} \mathrm{ft}^{-1}$. As a result, hydraulic-conductivity values of Quaternary sediments were constant to greater depths than those of Tertiary sediments and they decreased less rapidly with depth than did values of Tertiary sediments.

\section{Storage}

Specific storage $\left(S_{s}\right)$ and specific yield $\left(S_{y}\right)$ values were specified for both Quaternary and Tertiary sediments.

Although the aquifer system was treated as confined in the transient simulation, storage values representative of specific yield were specified in parts of model layers where unconfined conditions are assumed to occur. For example, $S_{y}$ values were assigned to layer 1 , which represented fluvial sediments, and to parts of layer 4 where Tertiary sediments are exposed at land surface. Storage properties in the rest of layer 4 where Tertiary sediments are overlain by Quaternary sediments were assigned $S_{s}$ values. The same $S_{s}$ value $\left(2 \times 10^{-6} \mathrm{ft}^{-1}\right)$ was specified for both Quaternary and Tertiary sediments based on work by Halford and Plume (2011). Four $S_{y}$ values were specified, with one value for Tertiary sediments and three values for the eastern and western alluvial fans and the fluvial sediments. The $S_{y}$ values for fluvial sediments were adjusted by multiplying the specified value by a normalized distribution of the $S_{y}$ values mapped by Dillingham (1980) that were presented earlier (fig. 13).

\section{Model Calibration}

The groundwater-flow model was calibrated by adjusting values of hydraulic conductivity, recharge, and streambed hydraulic-conductivity to minimize the difference between simulated groundwater levels and streamflows with those observed in wells and at gaging stations. Optimum parameter values were estimated through a nonlinear regression with UCODE 2005 (Poeter and others, 2005) that utilized parallel processing with a 28-processor cluster to minimize computation time. Computation of the exchange of water between the irrigation system and groundwater at the SFR2 boundary made the groundwater-flow problem highly nonlinear, a condition that was aggravated by the ten-fold variation in recharge from wet years to dry years. As a result, a numerical solution was difficult to obtain and necessitated a modification to the PCGN solver (Naff and Banta, 2008) described in appendix 2. Even with this modification a relatively large convergence criterion for hydraulic head $(0.01 \mathrm{ft})$ was required to obtain a solution. The accuracy of the solution was checked by comparing volumetric flow budgets and volumes of stream leakage computed by the PCGN solver with those computed with a smaller convergence criterion $(0.001 \mathrm{ft})$ by the NWT solver (Niswonger and others, 2011). Both results were quite similar. Although the NWT solver provided a more accurate numerical solution, the computation time was ten times longer than with the PCGN solver, which precluded use of the NWT solver in model calibration.

\section{Observations}

The nonlinear regression compared the simulated results with 5,686 water levels measured in 237 wells and flow at five streamflow-gaging stations. Water-level measurements 
Table 6. Groups of observations included in model calibration $A$, heads and $B$, flows.

\begin{tabular}{|c|c|c|c|c|c|c|}
\hline \multirow[t]{2}{*}{ A. Heads } & \multirow[b]{2}{*}{ Group } & \multirow[b]{2}{*}{ Wells } & \multirow[b]{2}{*}{ Median period of record } & \multirow[b]{2}{*}{$\begin{array}{c}\text { Median number } \\
\text { of } \\
\text { measurements }\end{array}$} & \multicolumn{2}{|c|}{ Standard deviation, in feet } \\
\hline & & & & & $\begin{array}{l}\text { Absolute } \\
\text { head }\end{array}$ & $\begin{array}{c}\text { Water-level } \\
\text { change }\end{array}$ \\
\hline & 1 & 27 & 24 & 68 & 1 & 0.45 \\
\hline & 2 & 23 & 12 & 34 & 1.4 & 0.58 \\
\hline & 3 & 26 & 2 & 11 & 2 & 0.71 \\
\hline & 4 & 161 & - & 1 & 3.2 & 1 \\
\hline \multicolumn{7}{|l|}{ B. Flows } \\
\hline & & \multicolumn{3}{|c|}{ Gaging station } & & \\
\hline & Source & Number $^{1}$ & \multicolumn{2}{|l|}{ Name } & Period of record & $\begin{array}{c}\text { Coefficient } \\
\text { of variation, } \\
\text { percent }\end{array}$ \\
\hline & USGS & & & & & \\
\hline & & 8 & \multicolumn{2}{|l|}{ Carson River near Genoa } & $1 / 2002-9 / 2005$ & 10 \\
\hline & & 9 & \multicolumn{2}{|l|}{ Carson River near Carson City } & $1 / 1971-9 / 2005$ & 10 \\
\hline & FWM & & & & & \\
\hline & & FWM3 & \multicolumn{2}{|c|}{ West Fork Carson River at Dressler Lane } & $4 / 1984-9 / 2005$ & 10 \\
\hline & & FWM4 & \multicolumn{2}{|c|}{ Brockliss Slough at Ruhenstroth dam } & $4 / 1984-9 / 2005$ & 10 \\
\hline & & FWM5 & \multicolumn{2}{|l|}{ Brockliss Slough at Scossa box } & 4/1984-9/2005 & 10 \\
\hline
\end{tabular}

${ }^{1}$ Number given in table 1.

were obtained from the USGS National Water Information System (NWIS) database for well data. This database included information on the screened interval and the well depth. The measurement depth in the model was assumed to be the well depth if the screened interval was not noted. Forty wells are shallow (less than $20 \mathrm{ft}$ deep), whereas the mean well depth for the remaining wells is about $200 \mathrm{ft}$ with an average screen length of $70 \mathrm{ft}$.

The wells were divided into four groups based on the period of record for each well (table $6 A$ ). Water levels in group 1 wells were generally measured from 1981 through 2005 , whereas group 2 wells have a shorter period of record (12 years), with most measurements made after 1990. Group 3 wells have generally been measured for only 2 years since 2000 . The remaining wells were assigned to group 4 and have mostly been measured once, although several wells were measured for 3 to 4 years in the 1980s. Different weights were specified for absolute head observations (the first measured water level) than for water-level-change observations, which were more numerous. Higher weights were assigned to absolute head observations where multiple measurements were made (group 1 wells), and lower weights were assigned to wells with only single or a few observations of absolute head (group 4 wells). Table $6 A$ lists the assumed standard deviation $\sigma$ in measurement error for each type of observation by group. The weight $w$ for each observation is equal to $1 / \sigma^{2}$.

Streamflow measurements obtained from the USGS NWIS database and the FWM database were compared; simulated flows were computed by the SFR2 package. Average, quarterly flow-observations used in model calibration were computed from mean daily flows measured at two USGS gaging stations and monthly flows measured at three FWM gaging stations. The period of record for the USGS Carson River gaging station near Carson City spanned the entire simulation period (1970-2005), whereas measured flow was available at the USGS Carson River gaging station near Genoa only from 2002 through 2005 (table 6B). Flow measurements for the FWM gaging stations were available from 1984-2005. All flow observations were assigned weights based on a coefficient of variation in measurement error of 10 percent. The resulting weights in flow observations resulted in weighted residuals (observed minus simulated values) that were comparable in magnitude with weighted residuals in heads, so that both observation groups influenced the regression equally. Quarterly flow observations for six other FWM gaging stations (Allerman Canal-FWM6, Heyburn Ditch-FWM12, Virginia Ditch-FWM7, Cottonwood Slough-FWM10, Edna Slough-FWM9 and Rocky Slough-FWM8, fig. 7) were used to specify flow diversions from the irrigation system at the SFR2 boundary. Hydrographs of measured flows at these sites were compared with simulated flows to verify that the simulation adequately represented the historical period, but these data were not included in the nonlinear regression. 


\section{Model Fit}

Residual plots for heads and flows (observed minus simulated values) indicate that the model simulates the groundwater system reasonably well. Residual plots for absolute head show little bias in model error with the mean weighted residual near zero (fig. 22). The standard error (SE) of the weighted residuals for absolute head is $16.6 \mathrm{ft}$, which is slightly larger than the SE for water-level change and flow and indicates greater influence in the regression (table 7). The SE in the unweighted absolute head is $39.2 \mathrm{ft}$ or 3.6 percent of the 1,090 - $\mathrm{ft}$ measured range. Nearly all the simulated heads are within $50 \mathrm{ft}$ of the measured value. The largest errors in absolute head occur along the basin margins; heads are generally under predicted within the western alluvial fans that border the Carson Range and over predicted in eastern alluvial fans that border the Tertiary sediments (fig. 23). Heads are also under predicted along Pine Nut Creek west of Fish Spring Flat.
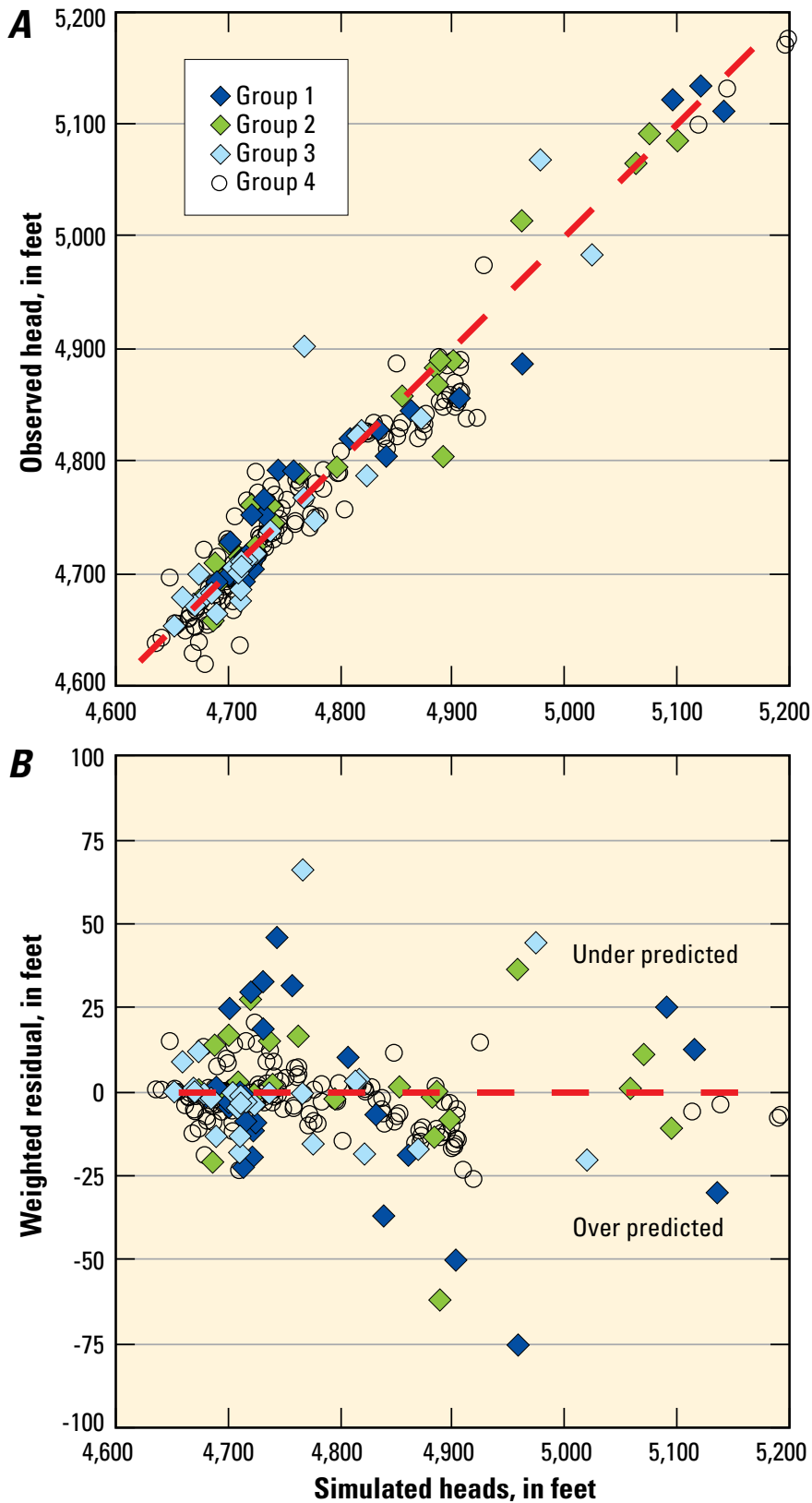

Figure 22. Residual plots for simulated absolute heads in Carson Valley groundwater model: $A$, relation between simulated and observed values; $B$, relation between simulated values and weighted residuals. 
Table 7. Parameter values in Carson Valley groundwater model specified or estimated through nonlinear regression.

[Optimal values are shaded. $\mathrm{ft} / \mathrm{d}$, feet per day; ft, feet; in/yr, inches per year; ft-1, inverse feet]

\begin{tabular}{|c|c|c|c|c|}
\hline Parameter & Abbreviation $^{1}$ & Value & $\begin{array}{c}\text { Approximate } \\
\text { 95-percent individual } \\
\text { confidence interval }\end{array}$ & $\begin{array}{r}\text { Coefficier } \\
\text { of variatio } \\
\text { percent }\end{array}$ \\
\hline \multicolumn{5}{|l|}{ Horizontal hydraulic-conductivity, $K_{x y}$ : } \\
\hline \multicolumn{5}{|l|}{ Quaternary sediments, factor ${ }^{2}$} \\
\hline fluvial sediments & $\mathrm{Q}_{\mathrm{fl}}$ & 4.7 & $5.7-4.4$ & 2.3 \\
\hline western alluvial fan & $\mathrm{Q}_{\mathrm{al}-\mathrm{W}}$ & 3.7 & $4.1-3.3$ & 4.4 \\
\hline northwestern alluvial fan & $\mathrm{Q}_{\mathrm{al}-\mathrm{NW}}$ & 6.8 & $7.5-6.2$ & 2.5 \\
\hline eastern alluvial fan & $\mathrm{Q}_{\mathrm{al}-\mathrm{E}}$ & 9.9 & $10.8-9.2$ & 1.8 \\
\hline southeastern allluvial fan & $\mathrm{Q}_{\mathrm{al}-\mathrm{SE}}$ & 0.6 & & \\
\hline \multicolumn{5}{|l|}{ Tertiary sediments, ft/d } \\
\hline northern sediments & $\operatorname{Ter}_{\mathrm{N}}$ & 5.8 & $6.1-5.5$ & 1.6 \\
\hline northwestern sediments & $\operatorname{Ter}_{\mathrm{NW}}$ & 3 & $3.3-2.8$ & 4.2 \\
\hline southern sediments & $\operatorname{Ter}_{\mathrm{S}}$ & 6.9 & $7.3-6.5$ & 1.5 \\
\hline accomodation zone & $\operatorname{Ter}_{\mathrm{az}}$ & 11.6 & & \\
\hline eastern sediments & $\operatorname{Ter}_{\mathrm{E}}$ & 2.9 & & \\
\hline buried sediments & Ter $_{\text {deep }}$ & 1 & & \\
\hline
\end{tabular}

Vertical anisotropy, $K_{x y} / K_{z}$, dimensionless:

Quaternary sediments

fluvial sediments western alluvial fans eastern alluvial fans

Tertiary sediments

$$
\begin{array}{r}
\text { northern sediments } \\
\text { northwestern sediments } \\
\text { southern sediments } \\
\text { accomodation zone } \\
\text { eastern sediments } \\
\text { buried sediments }
\end{array}
$$

$\begin{array}{rl}8,500 & 9,700-7,400 \\ 1.4 & \\ 2.6 & \end{array}$

770

770

1.2

1.2

770

770
0.8

Storage:

Specific yield, $S_{y}$, dimensionless:

Quaternary sediments

fluvial sediments

$0.3^{2}$

western alluvial fans

0.2

eastern alluvial fans

0.1

Tertiary sediments

0.1

Specific storage, $S_{s}, \mathrm{ft}^{-13}$ :

$2 \times 10^{-6}$ 
Table 7. Parameter values in Carson Valley groundwater model specified or estimated through nonlinear regression.—Continued [Optimal values are shaded. ft/d, feet per day; ft, feet; in/yr, inches per year; $\mathrm{ft}-1$, inverse feet]

\begin{tabular}{|c|c|c|c|c|}
\hline Parameter & Abbreviation ${ }^{1}$ & Value & $\begin{array}{c}\text { Approximate } \\
\text { 95-percent individual } \\
\text { confidence interval }\end{array}$ & $\begin{array}{c}\text { Coefficient } \\
\text { of variation, } \\
\text { percent }\end{array}$ \\
\hline \multicolumn{5}{|l|}{ Recharge, $R c h$, percent ${ }^{4}$ : } \\
\hline \multicolumn{2}{|l|}{ west Carson Range } & 43 & $47-40$ & 4.1 \\
\hline \multicolumn{2}{|l|}{ northwest Carson Range 5} & 100 & $110-90$ & 3.5 \\
\hline \multicolumn{2}{|l|}{ southeast Pine Nut Mountains } & 62 & $67-57$ & 4.1 \\
\hline \multicolumn{5}{|l|}{ Streambed hydraulic conductivity, $K_{s t r}, \mathrm{ft} / \mathrm{d}$ : } \\
\hline \multicolumn{5}{|l|}{ Carson River } \\
\hline \multicolumn{2}{|l|}{ main stem } & 7.3 & $11-4.7$ & 11 \\
\hline \multicolumn{5}{|l|}{ Irrigation ditches } \\
\hline \multicolumn{5}{|l|}{ Upland } \\
\hline \multicolumn{2}{|l|}{ center } & 0.9 & & \\
\hline \multicolumn{2}{|l|}{ north } & 0.2 & $0.3-0.2$ & 7 \\
\hline \multicolumn{2}{|l|}{ east } & 0.3 & & \\
\hline \multicolumn{2}{|l|}{ south } & 0.5 & & \\
\hline \multicolumn{5}{|l|}{ Lowland } \\
\hline \multicolumn{2}{|l|}{ center } & 15.4 & $24-10$ & 8.2 \\
\hline \multicolumn{2}{|l|}{ north } & 21.6 & & \\
\hline
\end{tabular}

${ }^{1}$ See figure 19.

${ }^{2}$ Factor multiplied by interpolation.

${ }^{3}$ Quaternary and Tertiary sediments.

${ }^{4}$ Percent of value calculated by PRMS watershed models

5 Jack's Valley.

${ }^{6}$ Value at assumed upper constraint. 


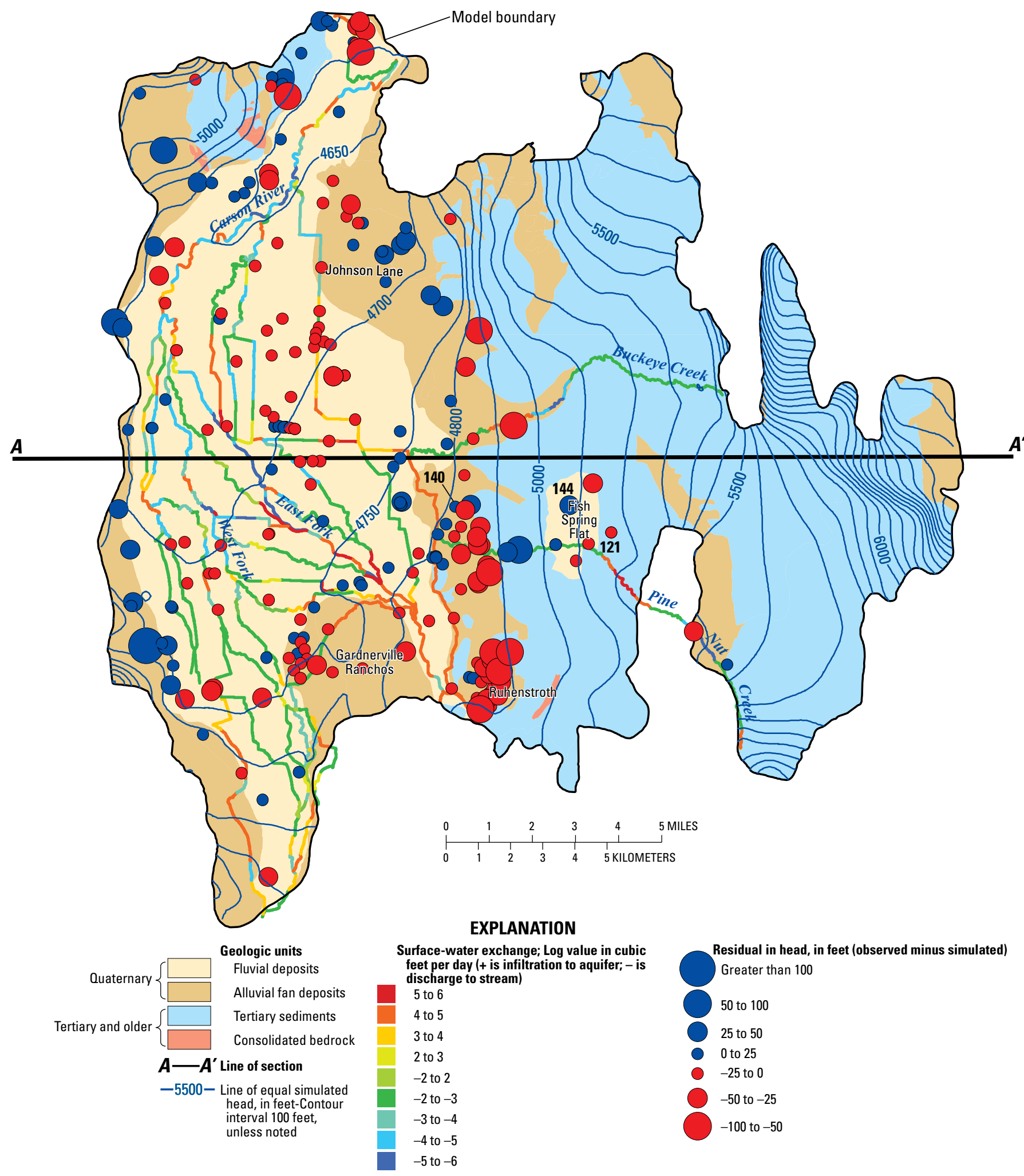

Figure 23. Simulated water table in the summer quarter of water year 2005, locations and rates of surface-water exchange, and spatial distribution of absolute-head residuals. 
Residual plots for water-level change show little bias for most of the 5,449 measurements with the mean weighted residual near zero (fig. 24). The SE of the weighted residuals for water-level change is $10.3 \mathrm{ft}$, and the absolute error is $5.7 \mathrm{ft}$ or 8.3 percent of the 68 - $\mathrm{ft}$ measured range. The largest residuals are for three wells located along the western alluvial fans and in Jacks Valley where observed changes are under predicted (for example, well 306, fig. 25), and for one well in Fish Spring Flat (well 121, fig. 23) where changes are over predicted. Water levels on the eastern side of the valley have declined more than $15 \mathrm{ft}$ near Fish Spring Flat (wells 144 and 150 ) and the Ruhenstroth subdivision (well 55) and more than $10 \mathrm{ft}$ near Gardnerville Ranchos (well 83). These observed declines are well simulated, although the absolute head in some areas is either over or under predicted (fig. 25). Waterlevel changes in response to transitions from wet to dry periods are observed and simulated along the western side of the valley (wells 137 and 306). Water-level changes in response to pumping in deep wells in the center of the valley are also well represented in the model simulation (wells 125 and 175). An additional 35-yr transient simulation was conducted that represented natural conditions by omitting groundwater pumping and streamflow diversions. No water-level declines were simulated for the Johnson Lane, Ruhenstroth, and Gardnerville areas, indicating that declines in these areas are the result of pumping. Water-level decline simulated near Fish Spring Flat was about one half that simulated by the calibration simulation, however, indicating that part of the decline in this area has been response to drier conditions since 1987.
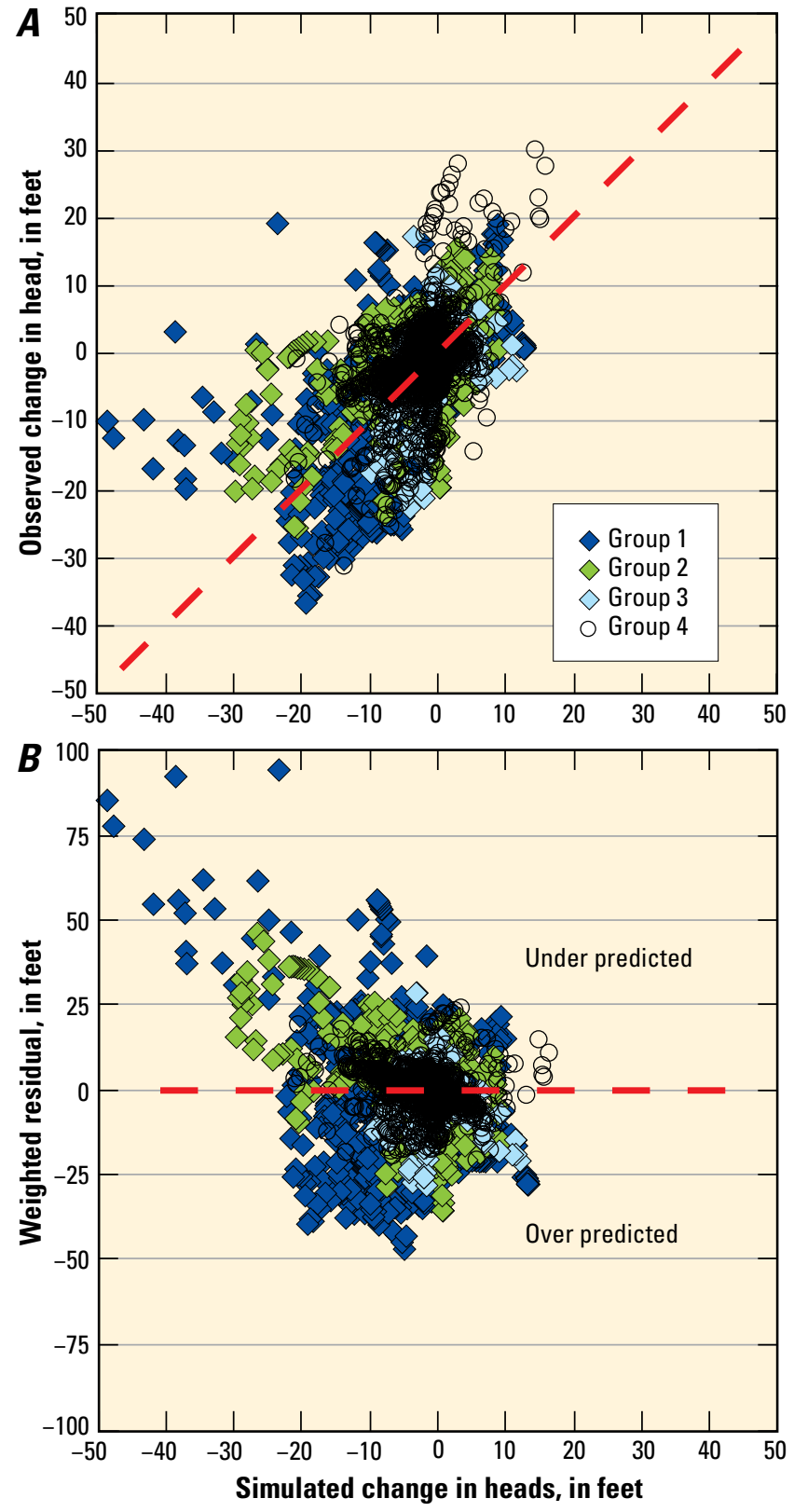

Figure 24. Residual plots for simulated water-level changes in the Carson Valley groundwater model: $A$, relation between simulated and observed values; $B$, relation between simulated values and weighted residuals. 

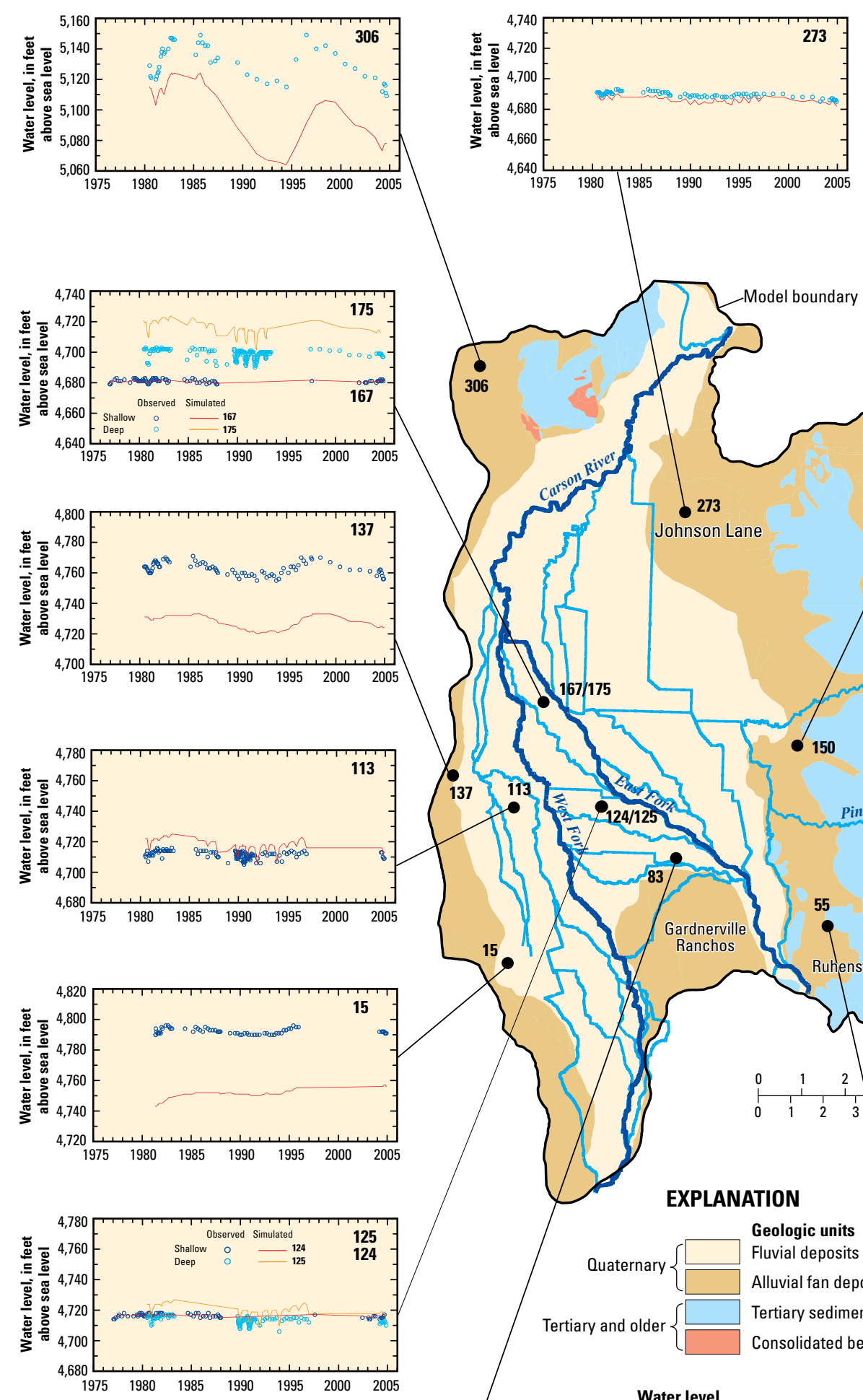

\section{EXPLANATION}
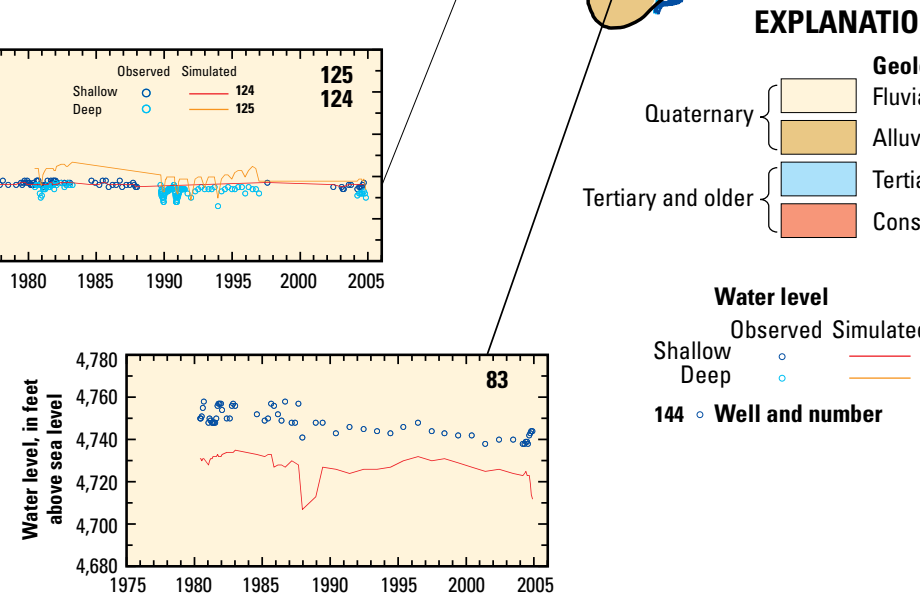

Geologic units Fluvial deposits Alluvial fan deposits Tertiary sediments Consolidated bedrock

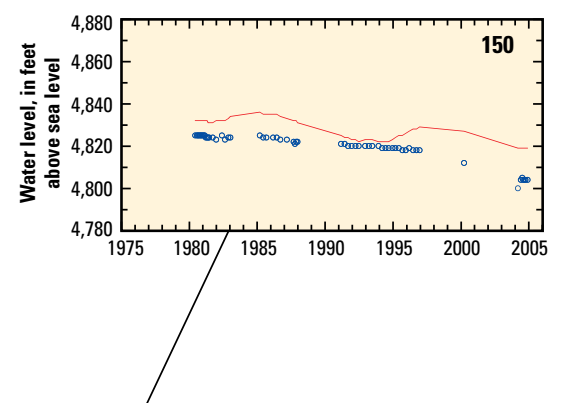


Residual plots for flows show little bias for measurements at the five gaging stations, although the lowest flows in the Carson River are over predicted (fig. 26A).The SE of the weighted residuals for flows is $6.7 \mathrm{ft}$, and weighted residuals are largest for the smallest flows (fig. 26B). Most observed flows at the USGS gages on the Carson River are well simulated, as are flows at the FWM gages on drainage ditches, although low flows in the Carson River are generally over predicted (fig. 27).

The greatest discrepancy between the observed and simulated flows in the Carson River likely results from the fact that storm runoff within the basin is not accounted for in the groundwater-flow model. For example, a rain on snow event at the beginning of water year 1997 caused flooding and sharply increased the observed outflow at the Carson River gage near Carson City (Thomas and Williams, 1997). The significance of storm runoff generated within Carson Valley is apparent in plots of simulated and observed changes in flow in the Carson River (fig. 28). As noted earlier in the report, the annual loss in downstream flow in the Carson River within Carson Valley was about 51,000 acre-ft/yr for the period 1990-2005. The simulated loss in flow matches observed losses reasonably well, although the simulated losses generally under predicted those observed since 1987. Large gains in flow were observed in water years 1983 and 1997, but losses were predicted by the model. If storm runoff were subtracted from the observed flow in the Carson River, the simulated flow would better match the observed flow. Storm runoff within the basin is not a frequent occurrence, however, and the volume of runoff has not been estimated.
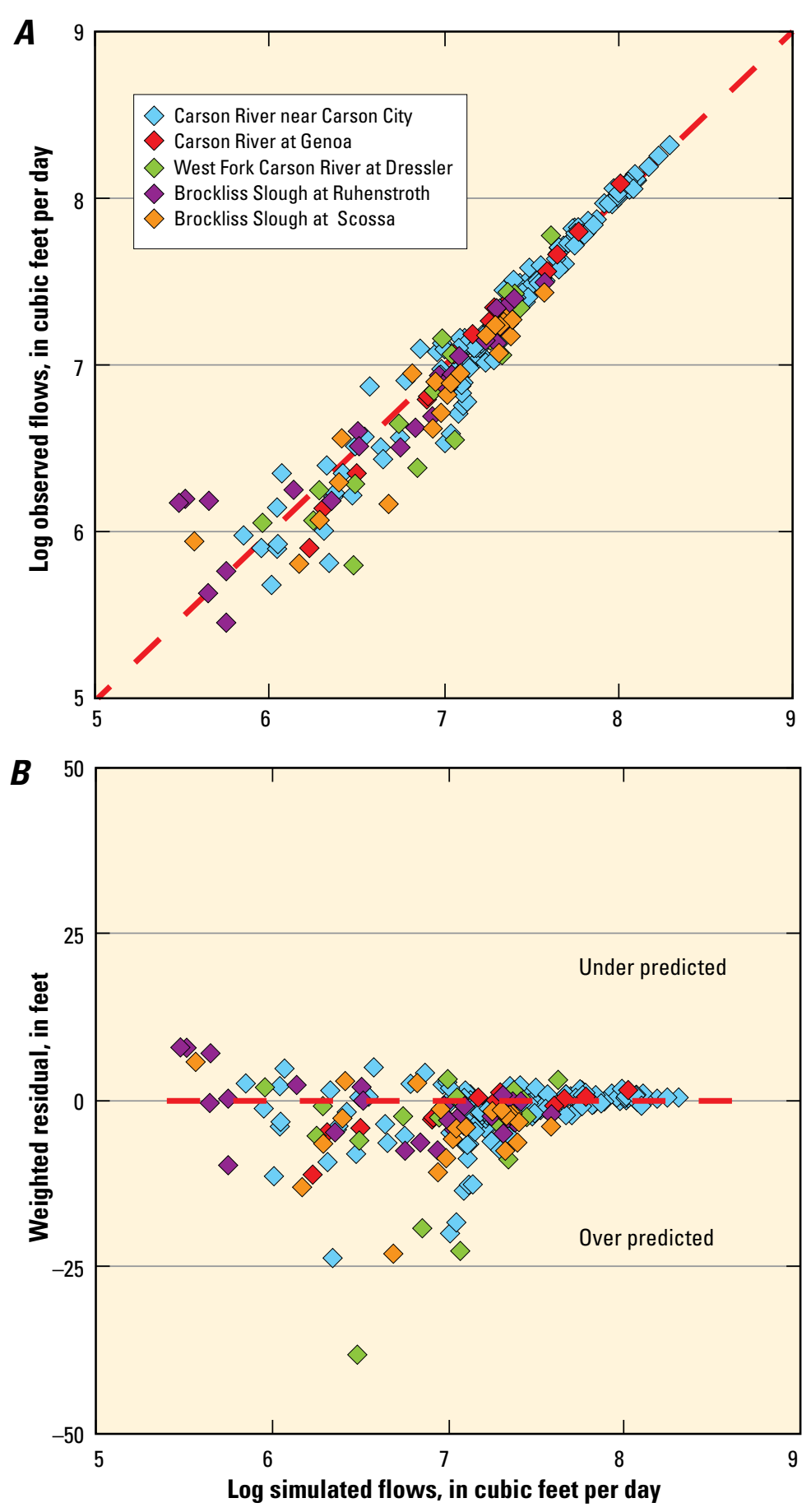

Figure 26. Residual plots for simulated flows in Carson Valley groundwater model: $A$, relation between simulated and observed values; $B$, relation between simulated values and weighted residuals. 

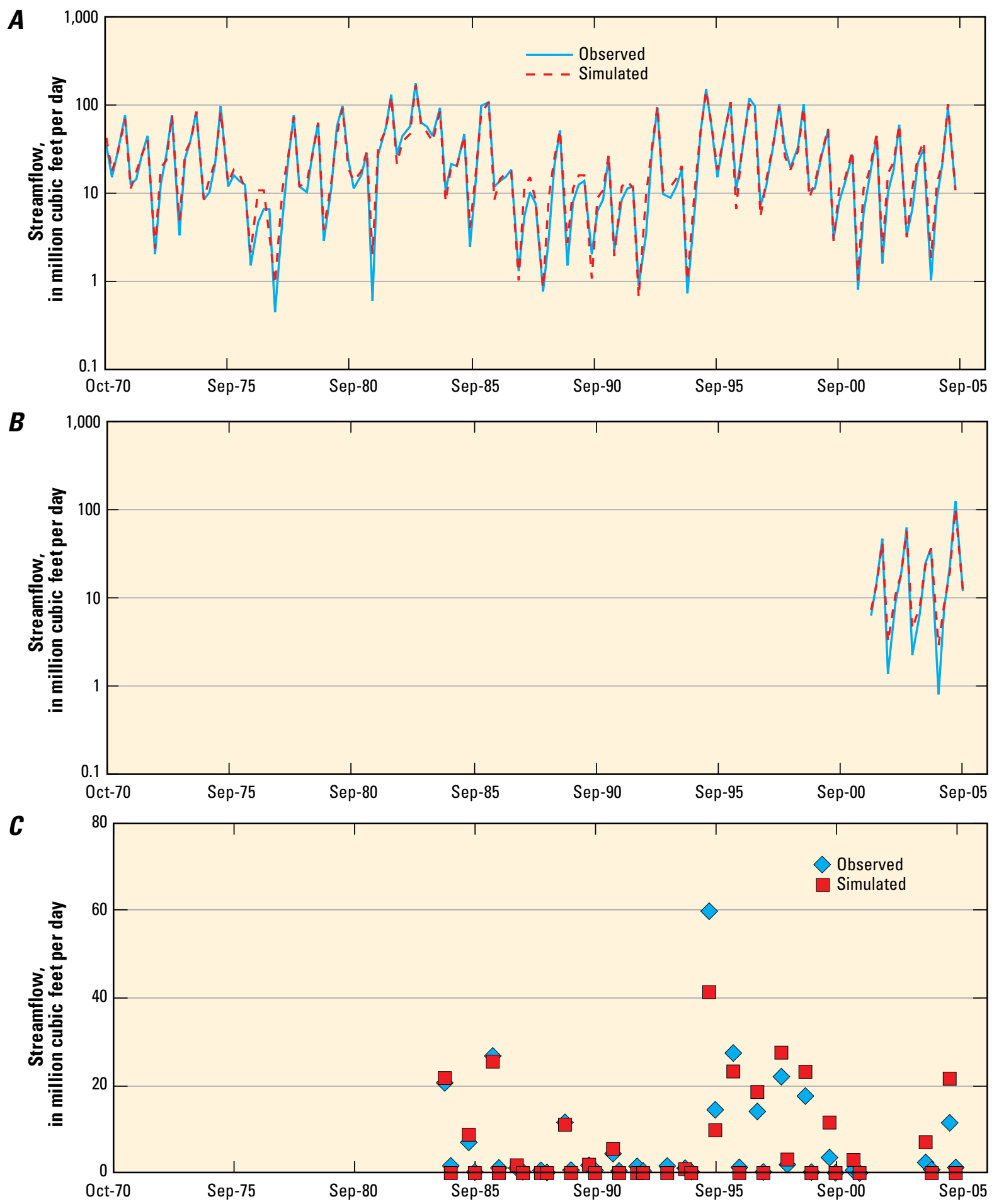

Figure 27. Simulated and observed flow hydrographs for streamflow gaging stations in the Carson Valley: $A$, Carson River near Carson City; $B$, Carson River near Genoa; $C$, West Fork Carson River at Dressler Lane; $D$, Brockliss Slough at Ruhenstroth dam; and $E$, Brockliss Slough at Scossa box. 

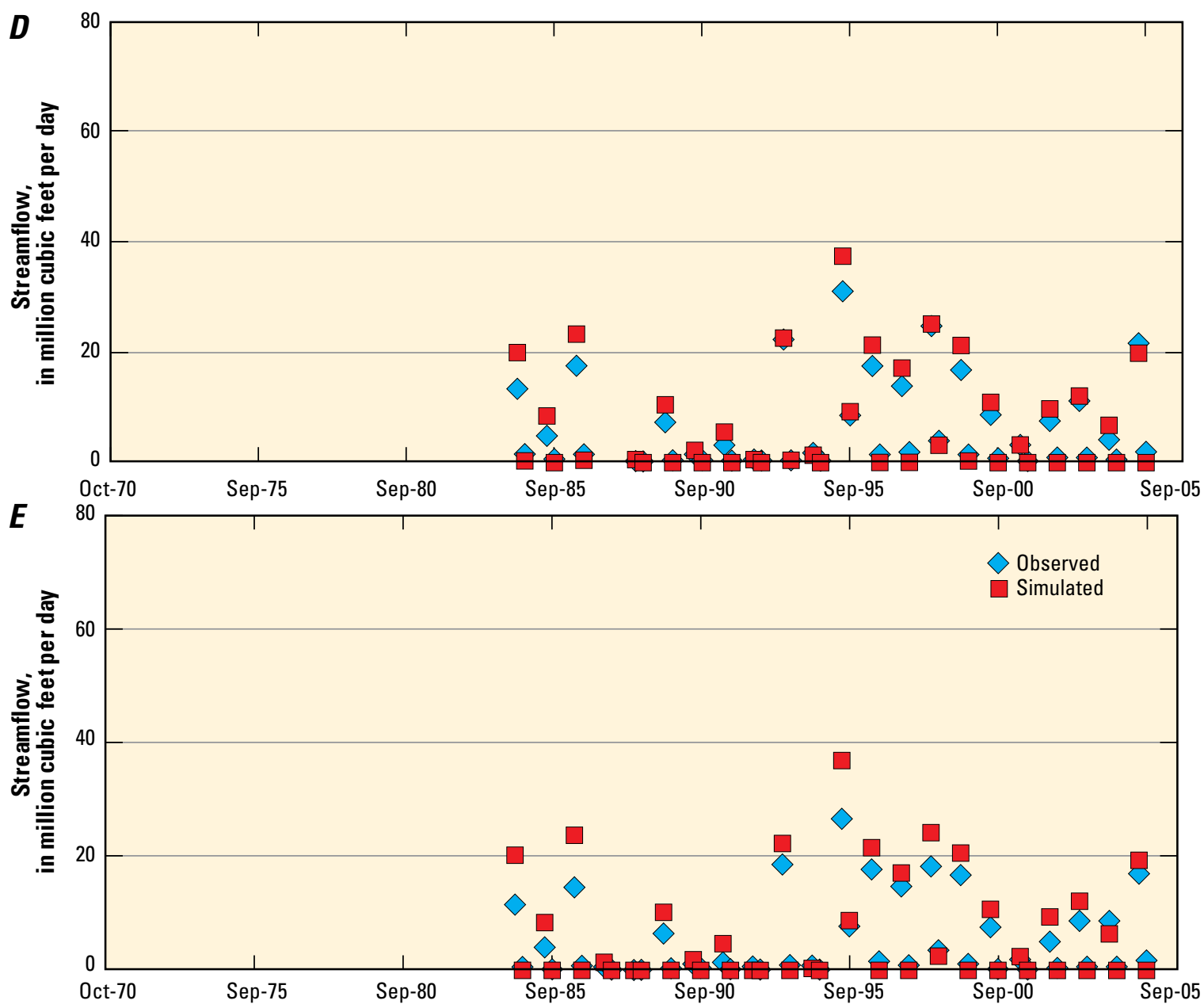

Figure 27. Simulated and observed flow hydrographs for streamflow gaging stations in the Carson Valley: $A$, Carson River near Carson City; $B$, Carson River near Genoa; $C$, West Fork Carson River at Dressler Lane; $D$, Brockliss Slough at Ruhenstroth dam; and $E$, Brockliss Slough at Scossa box.-Continued

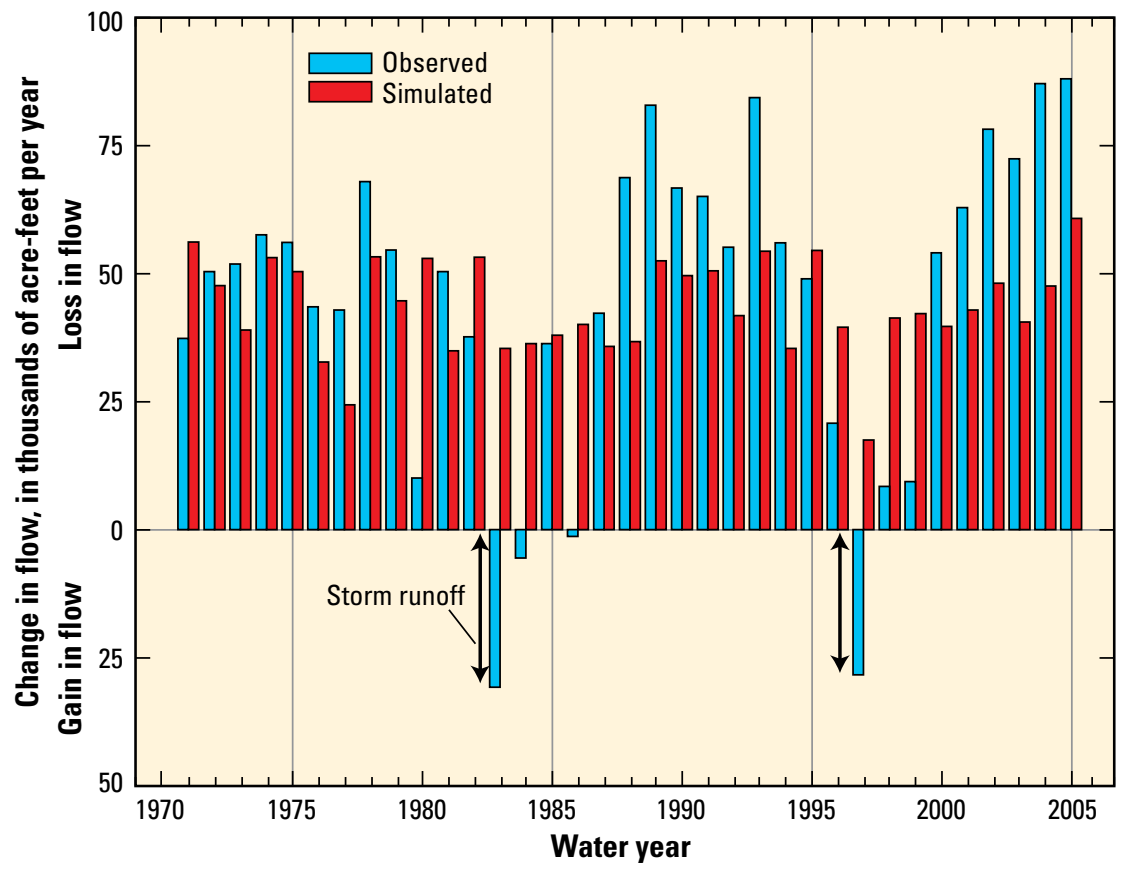

Figure 28. Simulated and observed loss in flow in the Carson River, water years 1971-2005. 


\section{Simulated groundwater flow}

The distribution of simulated heads indicates that groundwater flows westward through the Tertiary sediments toward the center of Carson Valley and then northward toward the outlet of the Carson River (fig. 23). The location of the simulated 4,700-ft contour in the center of the valley is similar to that of the 4,700-ft contour estimated from observed water levels in spring 1998 (fig. 14). A section view indicates the simulated hydraulic gradient is nearly flat at lower elevations in Carson Valley, but the gradient slopes upward through Tertiary sediments to the east (fig. 29). Simulated vertical gradients are upward near the center of Carson Valley, but are over predicted by as much as $20 \mathrm{ft}$ (well 175, fig. 25). Simulated flow paths indicate that groundwater flows faster through the center of Carson Valley where the hydraulic conductivity of fluvial sediments is larger, and groundwater flows slower through the smaller hydraulic-conductivity Tertiary sediments to the east (fig. 30). The rate of flow in all areas declines with depth, reflecting the assumed decrease in hydraulic conductivity. The direction of flow also changes with depth in the center of the valley as a result of the large vertical anisotropy estimated for the fluvial sediments. Shallow flow in the center of the valley is towards drainage channels, while deeper flow is generally directed toward the basin outlet to the north.

The distribution of streamflow losses and gains simulated throughout the valley in the summer quarter of 2005 (fig. 23) is in general agreement with that determined by Maurer and Berger (2007, p. 50) from data collected over several years. The greatest losses to infiltration are simulated in the southeastern part of the valley, and the greatest gains are simulated on the western and northern parts of the valley. The simulated distribution of recharge derived from irrigation fluctuated throughout the simulation in response to changes in streamflow available for diversion. For example, in the spring quarter of water year 2005 simulated irrigation was applied to about 30,000 acres and provided 55,000 acre-ft of recharge (fig. $31 \mathrm{~A}$ ). In contrast, streamflow available for diversion during the summer quarter of water year 2005 provided irrigation water for only about 24,000 acres, resulting in only 25,000 acre-ft of recharge (fig. $31 B$ ).

\section{Parameters}

The Carson Valley groundwater model was formulated with a total of 41 parameters, 18 of which were optimized through nonlinear regression. The values of other parameters were either fixed or estimated through regressions that lowered model error but did not converge to an optimal set of parameter values. Coefficients of variation (CV) for the 13 optimized hydraulic-conductivity and recharge parameters range from 0.8 to 4.4 percent (table 7 ), indicating that the regression is sensitive to the parameters and that the values are well estimated. The estimated values for the five streambed hydraulicconductivity parameters are less certain with $\mathrm{CV}$ values ranging from 7 to 17 percent. There is no significant correlation among the model parameters. The individual confidence intervals in table 7 are approximate and indicate qualitatively the uncertainty in estimated parameter values.

The sensitivity of the model to the estimated parameter values was assessed by comparing the composite-scaled sensitivities (CSS), which indicate the amount of information provided by all observations for each parameter (Hill, 1998). The CSS statistics indicate that the parameter sensitivities are highest for the hydraulic conductivity $(K)$ and recharge $(R c h)$ parameters associated with the Tertiary sediments in

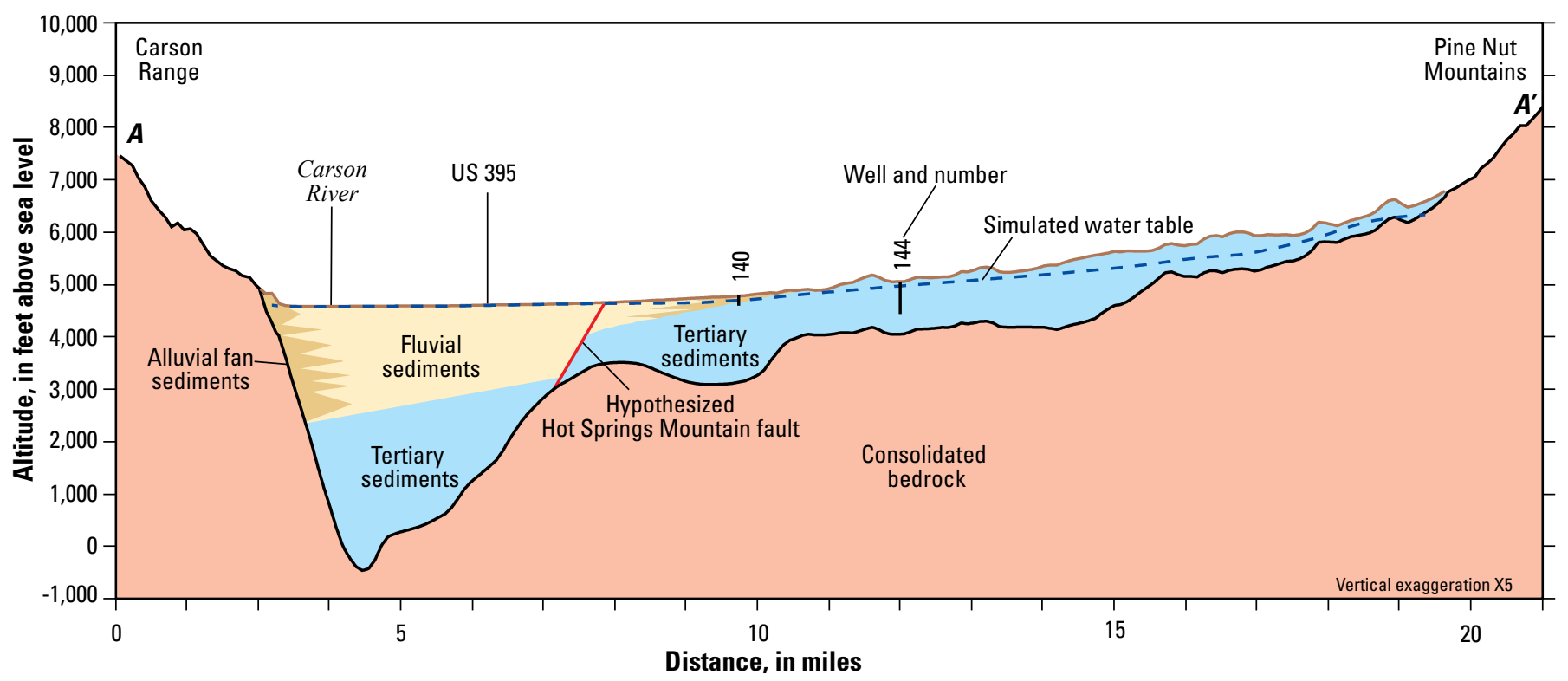

Figure 29. Simulated water table along section $A-A^{\prime}$ in the summer quarter of water year 2005 . 


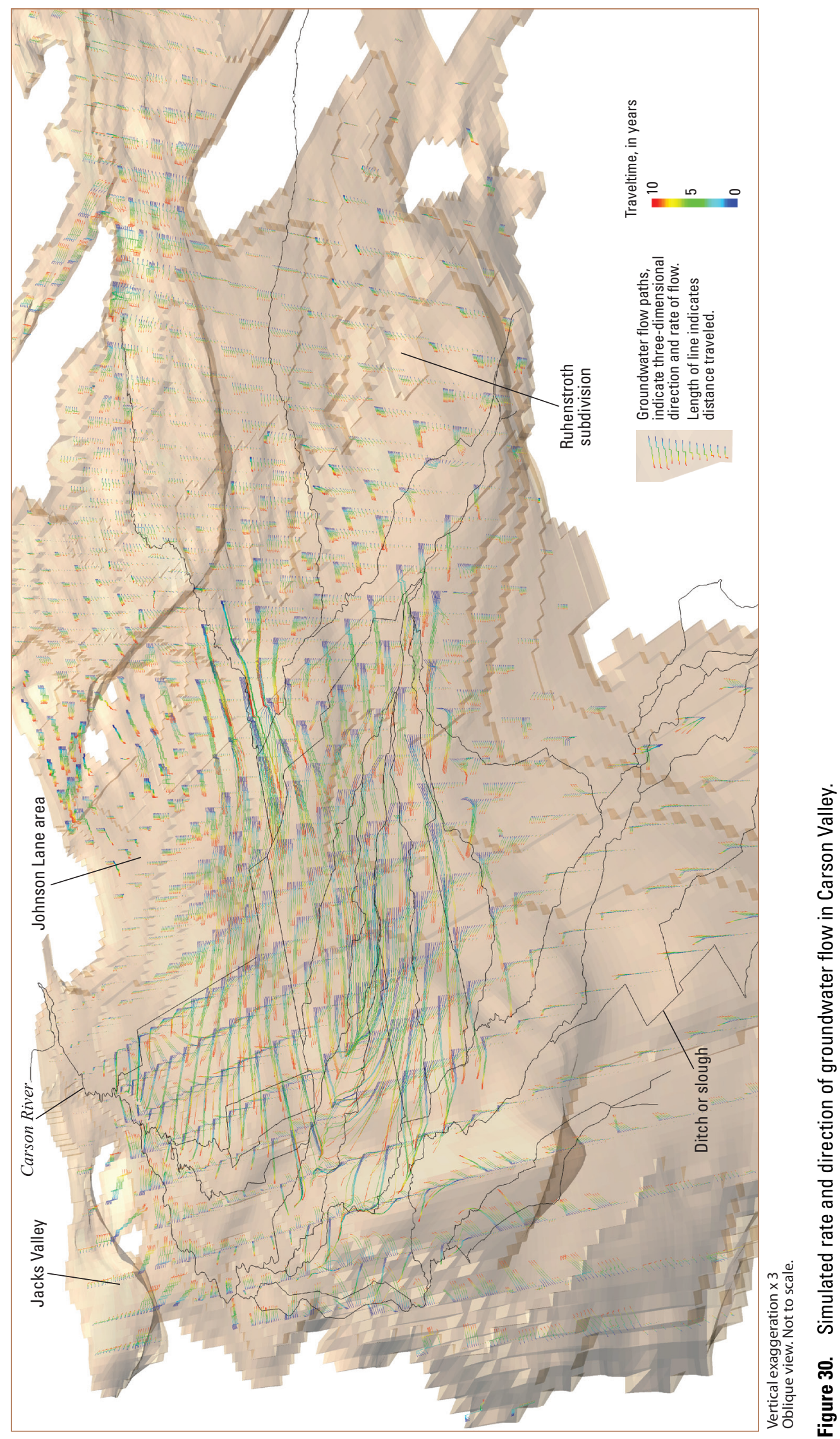




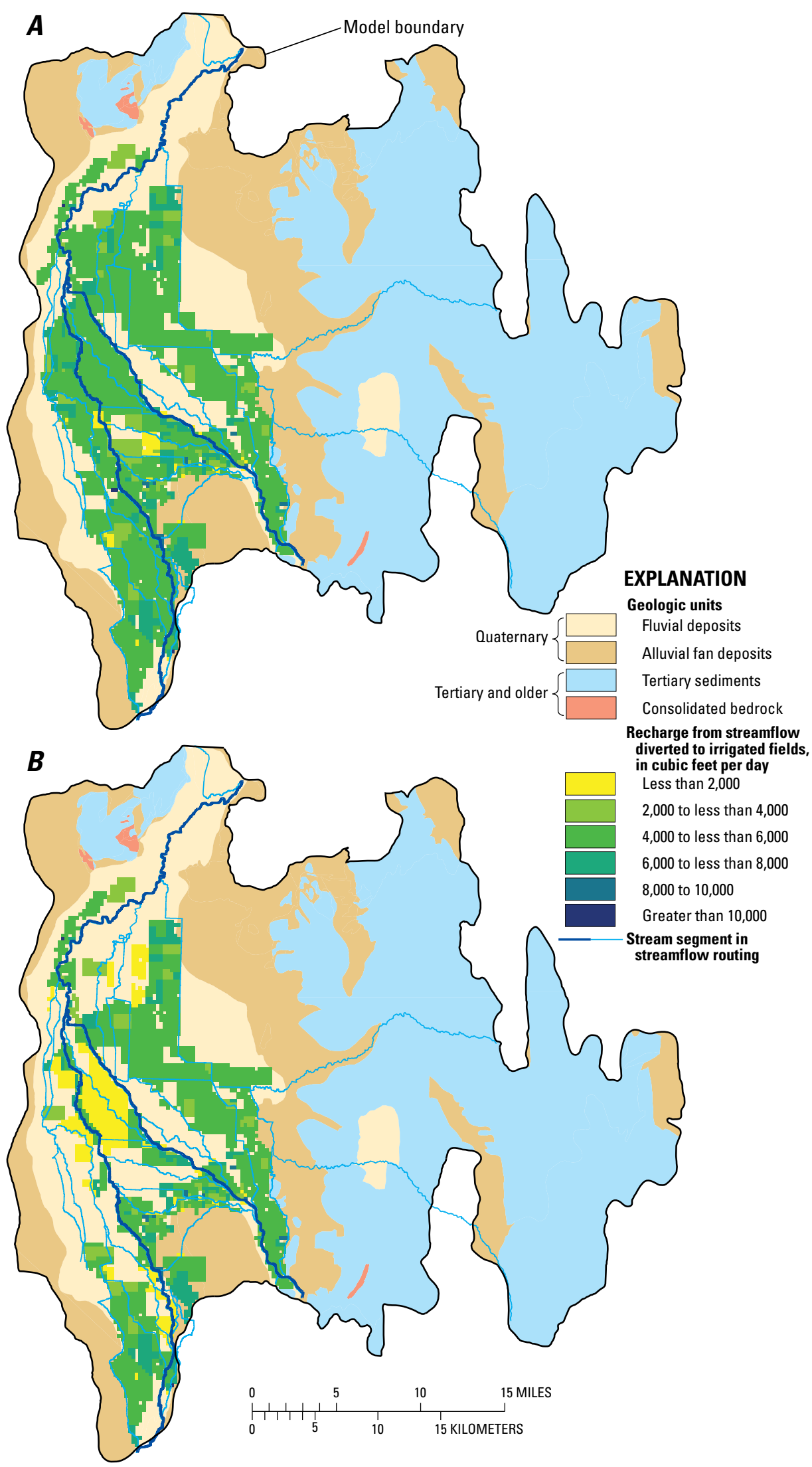

Figure 31. Simulated rate of recharge from streamflow diverted to irrigated fields in Carson Valley in water year 2005: $A$, spring quarter; $B$, summer quarter. the northern and southern parts of the basin, and they are lowest for the Tertiary vertical-anisotropy parameters and streambed hydraulic-conductivity parameters for the Carson River (fig. 32). Together the CV and CSS statistics indicate that changes to the optimized parameter values with $\mathrm{CV}$ values less than 10 percent would result in proportionally large increases in model error.

The $K_{x y}$ distribution for Quaternary fluvial and alluvial fan sediments in the Carson Valley groundwater model is obtained by multiplying the optimized $K_{x y}$ parameter values (table 7) by the kriged distribution of transmissivity $(T)$ values derived from the specific-capacity data (fig. 12), and dividing by the median wellscreen length ( $200 \mathrm{ft}$ ). Model $K_{x y}$ values are compared with the $T$ values estimated from specific-capacity data (fig. 11) by multiplying the geometric-mean $K_{x y}$ value by $200 \mathrm{ft}$. The resulting mean $T$ values (11,000 and $800 \mathrm{ft}^{2} / \mathrm{d}$ for the fluvial and alluvial fan sediments, respectively) are both within the third quartile of $T$ values estimated from specific-capacity data. The mean $T$ value for the fluvial sediments is slightly less than the maximum value $\left(13,000 \mathrm{ft}^{2} / \mathrm{d}\right)$ estimated for a previous model of Carson Valley by Maurer (1986). Optimized values of streambed hydraulic-conductivity $K_{\text {str }}$ are either less than or comparable to estimated $K_{x y}$ values of the Quaternary sediments, with larger values estimated for the Carson River and irrigation channels in lowlands near the center of the valley and smaller values estimated for channels in the uplands.

The optimized $K_{x y}$ values for Tertiary sediments ( 3.3 to $6.9 \mathrm{ft} / \mathrm{d}$ ) are larger than expected and yield transmisivity values more than 700 $\mathrm{ft}^{2} / \mathrm{d}$, which are higher than the third quartile of $T$ values estimated from specific-capacity data (fig. 11). In an alternative simulation the $K_{x y}$ values for Tertiary sediments were all reduced to a more reasonable value of $2 \mathrm{ft}^{2} / \mathrm{d}$. The $R c h$ values for Tertiary sediments were also reduced 


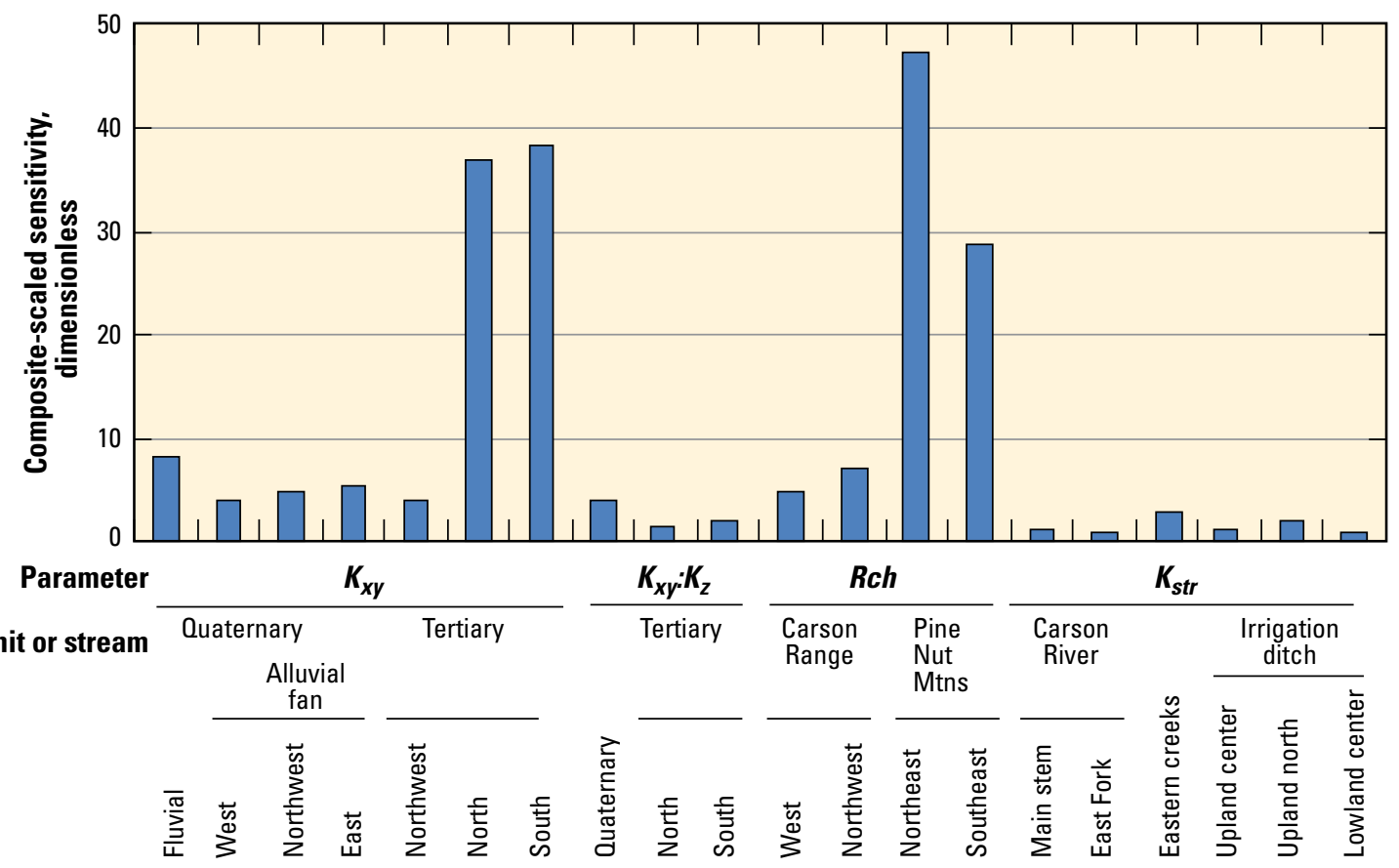

Figure 32. Composite-scaled sensitivities of optimal parameters in Carson Valley groundwater model.

by comparable amounts to preserve the same $K_{x y}$ : Rch ratios. Model error increased by 10 percent, but the poorer model fit was due solely to additional error in water-level change, while errors in absolute head and streamflows decreased slightly. The use of more reasonable $K_{x y}$ values for Tertiary sediments could, therefore, be justified to produce a model that slightly better matches heads and streamflows at the expense of a poorer match to water-level fluctuations.

The estimated vertical anisotropy $K_{x y} / K_{z}$ for the Quaternary fluvial sediments is large $(9,000)$ and reflects the presence of confining layers within the sediments. Maurer (1986) estimated a comparable value of vertical anisotropy $(10,000)$ in his previous model of Carson Valley. Observed water-level changes in artesian wells screened in deeper parts of the valley are not well simulated with smaller $K_{x y} / K_{z}$ values. The spatial distribution of fluvial sediments was divided into two zones in an alternative regression to separate the deeper sediments in the center of the valley from the shallower sediments, but the estimated $K_{x y} / K_{z}$ value for each zone was unchanged. The $K_{x y} / K_{z}$ values estimated for the Quaternary alluvial sediments are small (1.4 to 2.6), but the regression was not sensitive to these values, which were not optimized. The $K_{x y} / K_{z}$ value estimated for the Tertiary sediments in the accommodation and southern zones is also small (both 1.2) and was not optimized for the same reason. The $K_{x y} / K_{z}$ value estimated for remaining Tertiary sediments is large (500), which is reasonable because low permeability fine-grained (clay) layers are present within these sediments. In contrast, Tertiary sediments in the southern zone and in the accommodation zone are coarser grained (Muntean, 2001), so vertical anisotropy is expected to be less in both these zones.
Volumes of mountain-front recharge $\left(M F_{r c h}\right)$ estimated by the regression (table 7) differ from those estimated from PRMS watershed models by factors that range from 43 to 200 percent. The mean estimate of mountain-front recharge derived from the regression $(36,000 \mathrm{acre}-\mathrm{ft} / \mathrm{yr})$ is equivalent to the PRMS estimate, but about 70 percent of the mountainfront recharge simulated in the Carson Valley model enters along the Pine Nut Mountains. In contrast, the PRMS models estimate a nearly equal distribution of mountain-front recharge between the Carson Range and the Pine Nut Mountains. An alternate regression in which the PRMS recharge estimates were specified in the model simulation resulted in a 15-percent increase in model error, with errors in Carson River flow accounting for nearly all the increase.

The regression was sensitive to the specific-yield parameters, but it produced values that were unreasonably large (greater than 0.4), so these parameters were later omitted from the regression. The specific-yield values for Quaternary fluvial sediments were obtained by multiplying the normalized distribution of values presented previously (fig. 13) by the factor 0.3 , which yielded a mean value of 0.21 . Areas of waterlevel decline are limited within Carson Valley, so water-level measurements provide little information concerning the value of specific yield. Evidently, the regression-derived estimates acted to dampen seasonal fluctuations in simulated water levels, but the cause of the unreasonable estimates could not be linked to a single set of observations. 


\section{Water Budgets}

Annual groundwater budgets were computed for each water year in the 35-yr transient simulation (fig. 33); the mean annual budget for the period is shown on table 8 . All the components of the budgets were computed by the model

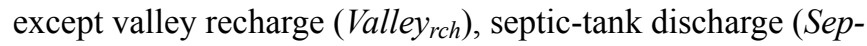
tic) and pumping (Pump) which were specified (table 4). The contributions of flow from Eagle Valley $\left(G W_{i n}\right)$ and Septic are too small to appear on the time-series plots and are neglected on the mean annual budget in table 8 . The length of the bars rises and falls on the time-series plots and indicates transitions from wet to dry periods. Stream infiltration $\left(\right.$ Stream $\left._{\text {infil }}\right)$ and mountain-front recharge $\left(M F_{r c h}\right)$ are the largest inflow components, and stream discharge (Stream disch $_{\text {) }}$ ) and evapotranspiration $\left(E T_{w t}\right)$ are the largest outflow components. Pumping has historically been less than 10 percent of discharge from the groundwater system, and agricultural recharge $\left(A g_{r c h}\right)$ has been less than 10 percent of recharge to the groundwater system. The time-series plots indicate that storage is an important part of the budget with larger inflows from storage in dry years and larger outflows to storage in wet years. As a result, the aquifer system is in a dynamic equilibrium and it is difficult to define a steady-state period from which to calculate an annual groundwater budget that is representative of average conditions.

The cumulative water budget for Carson Valley portrays the relative contributions of budget components for water years 1971-2005 (fig. 34). Steeply rising portions of the curve indicate wet periods while flatter portions indicate dry periods. This budget only includes inflows and outflows of water to the basin. Agricultural recharge and stream infiltration and discharge are not included in this water budget because these components of the groundwater budget are transfers of water within the basin. The cumulative plots indicate that streamflow is the dominant water-budget component and that evapotranspiration is the second largest component. Inflows from mountain-front and valley recharge and storage contribute nearly equal volumes to the water budget. Outflows to wells and storage are also equal in volume.

Table 8. Simulated mean-annual groundwater budget for Carson Valley from water year 1971 through 2005.

[Volumes in thousands of acre-feet]

\begin{tabular}{lcclcr}
\hline \multicolumn{1}{c}{ Inflow } & Volume & Percent & \multicolumn{1}{c}{ Outflow } & Volume & Percent \\
\hline Stream infiltration & 120.2 & 48.2 & Stream discharge & 125.9 & 50.5 \\
Mountain-front recharge & 36.4 & 14.6 & $\begin{array}{l}\text { Evapotranspiration from } \\
\text { water table }\end{array}$ & 70.8 & 28.4 \\
Storage & 44.1 & 17.7 & Storage & Net pumping ${ }^{1}$ & 15.2 \\
Valley recharge & 32.1 & 12.9 & & 14.6 \\
Agricultural recharge & 16.8 & 6.7 & Total & 249.3 \\
Total & 249.6 & 100.0 & & 100.0 \\
\hline
\end{tabular}

${ }^{1}$ Pumping minus infiltration of septic discharge.

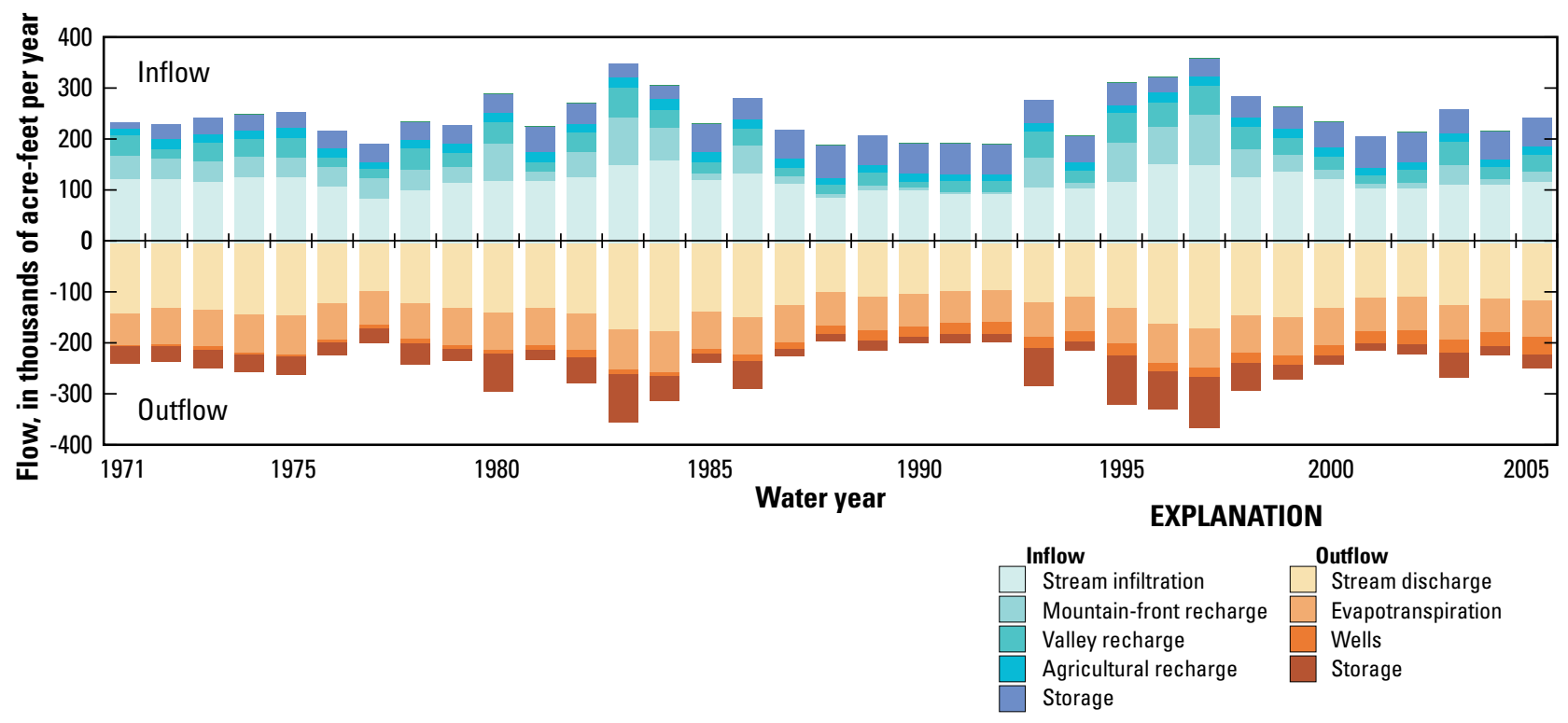

Figure 33. Groundwater budgets simulated for water years 1971-2005. 

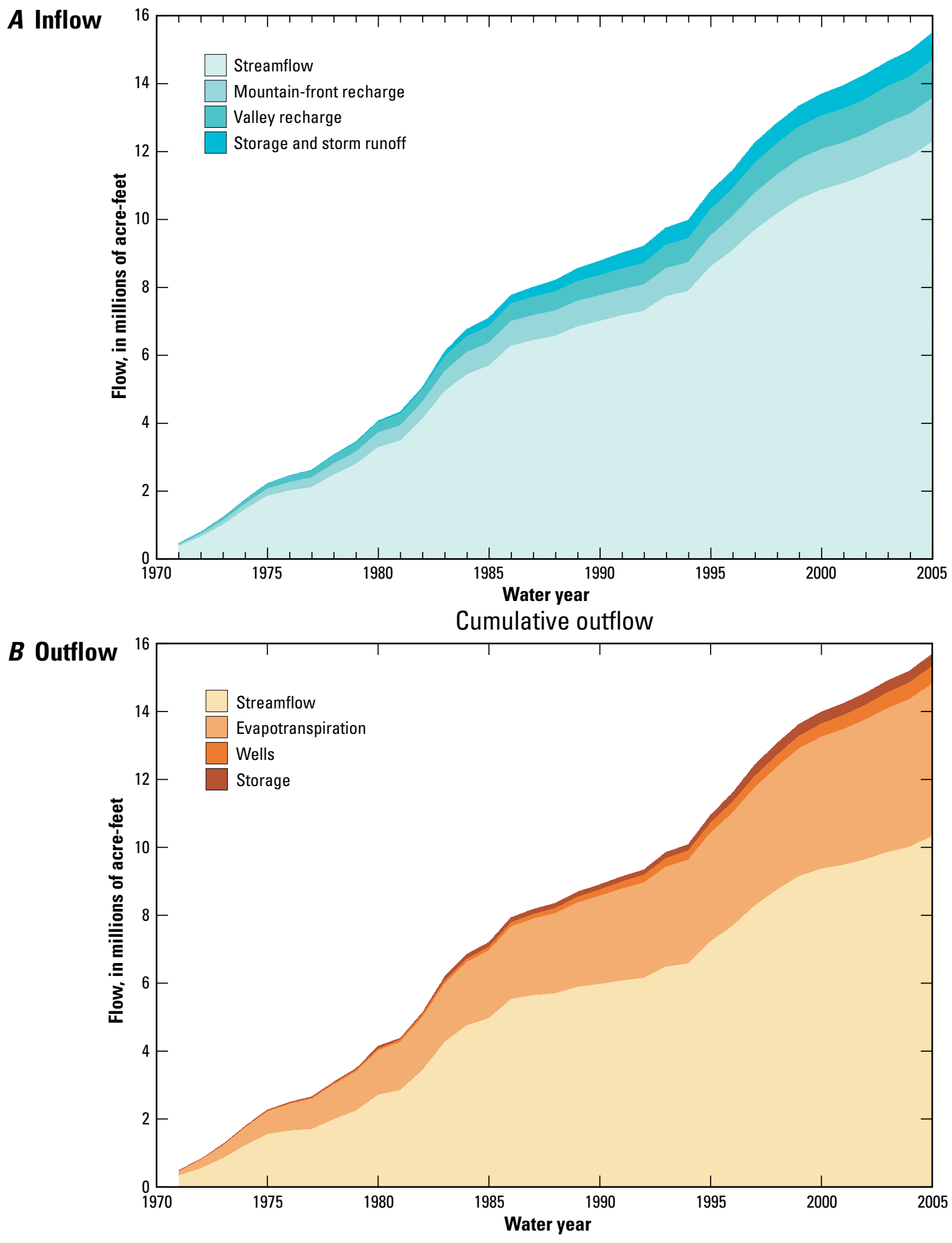

Figure 34. Cumulative water budgets simulated for water years 1971-2005: $A$, inflow; $B$, outflow. 
Simulated water budgets for Carson Valley for water years 1992 and 1997 (table 9) were prepared for comparison with the independently estimated, mean-annual water budget presented in table 3 for the period 1990-2005. Water years 1992 and 1997 were the driest and wettest years, respectively, during this period. The overall budget errors (about 2 percent) are reasonable considering potential errors in estimating the waterbudget components. The simulated water budgets include storage and, therefore, differ from the mean budget estimates presented in table 3. Flows of individual budget components and the total flow for these dry and wet years bracket the comparable values in mean budget and are consistent with earlier assessments. An assumed contribution of storm runoff was required to balance the budget in water year 1997 when flooding occurred.

Table 9. Simulated annual water budgets for Carson Valley in the 1992 and 1997 water years.

[Shaded volumes are estimated by Carson Valley groundwater-flow model. Volumes in thousands of acre-feet. ET, evapotranspiration]

\begin{tabular}{|c|c|c|}
\hline Inflow & 1992 & 1997 \\
\hline \multicolumn{3}{|l|}{ Streamflow: } \\
\hline East Fork & 127.0 & 438.3 \\
\hline West Fork & 39.6 & 132.9 \\
\hline Carson Range $^{1}$ & 1.4 & 22.5 \\
\hline Valley recharge $^{2}$ & 20.6 & 58.5 \\
\hline Mountain-front recharge & 4.7 & 97.1 \\
\hline Storm runoff ${ }^{3}$ & - & 63 \\
\hline Storage ${ }^{4}$ & 42.5 & \\
\hline Total & 235.8 & 812.3 \\
\hline
\end{tabular}

\begin{tabular}{|c|c|c|}
\hline Outflow & 1992 & 1997 \\
\hline Stream flow & 101.5 & 599.5 \\
\hline \multicolumn{3}{|l|}{ Evapotranspiration } \\
\hline Groundwater 5 & 63.0 & 77.3 \\
\hline Agricultural 6 & 41.1 & 63.3 \\
\hline Net pumping ${ }^{7}$ & 22.1 & 18.1 \\
\hline Storage ${ }^{4}$ & & 65.7 \\
\hline Total & 227.7 & 823.9 \\
\hline \multicolumn{3}{|l|}{${ }^{1}$ Winter runoff. } \\
\hline \multicolumn{3}{|c|}{${ }^{2}$ Includes precipitation, water-rights applications and imported effluent. } \\
\hline \multicolumn{3}{|l|}{${ }^{3}$ Assumed runoff within basin. } \\
\hline \multicolumn{3}{|l|}{${ }^{4}$ Net storage. } \\
\hline \multicolumn{3}{|c|}{${ }^{5}$ ET from water table for all vegetation types. } \\
\hline \multicolumn{3}{|c|}{${ }^{6} \mathrm{ET}$ from application of stream-flow diversions on irrigated fields. } \\
\hline${ }^{7}$ Pumping minus infiltration of septic $d$ & & \\
\hline
\end{tabular}

\section{Model uncertainty}

There are three types of errors that cause heads and flows simulated by the groundwater model to differ from those that are observed. The first source of error and most difficult to quantify results from errors in the model design, which entails representing the aquifer system as a set of mathematical equations. This design error reflects both the approximation of complex physical processes by theoretical equations and the uncertainty regarding the actual geometry of the aquifer system, which can only be characterized at a limited number of locations through boreholes or surface exposures. The second source of error is related to the values of hydraulic properties (parameters) that must be specified in the mathematical model. These values can sometimes be estimated independently through field measurements (for example, hydraulic conductivity through aquifer tests), but often must be inferred indirectly (for example, specific yield through grain-size analysis or recharge through flow measurements). The parameter error reflects both the uncertainty in the estimated values and in the pattern of their distribution within the model. Parameter error can be quantified using statistical measures that are computed by nonlinear regression. The third source of error results from measurement of the observations themselves and is reflected by weights assigned to the observations in the regression. This error is commonly assumed to be much less than the other two types of error.

Both design error and parameter error can be reduced through model calibration by considering alternative model designs and by estimating parameter values through nonlinear regression, but ultimately a point is reached beyond which further reduction in error is difficult. Halford and Plume (2011) refer to irreducible error, which can only be lowered by obtaining additional information concerning uncertain model processes, geometry, and parameters. The irreducible error, therefore, reflects the current state of knowledge concerning the aquifer system. Design error in the Carson Valley model was assessed through several alternative models, which are discussed in the following paragraphs. None of the alternatives greatly reduced model error. Some alternatives increased model error only slightly (less than 15 percent) and served to indicate the range of possible parameter values that can be considered. Parameter error in the Carson Valley model is reflected by the CSS and CV statistics and by the approximate individual confidence intervals computed for the parameter estimates. Parameter error could be further assessed (and perhaps reduced) through calibration using regularization with pilot points, as described by Doherty (2003) and Halford and Plume (2011). This approach was beyond the scope of the current study due to limitations of time and computational capacity.

One source of uncertainty in the model design is the assumption of confined conditions for the unconfined aquifer system. As discussed previously, unconfined conditions were accounted for in model layers that intersect the water table during calibration using the factor Sat $_{\text {factor }}$ in the computation 
of transmissivity to account for partial saturation and by the specification of storage values representative of specific yield. Recently (May 2011), an additional numerical solver became available within MODFLOW that allowed the solution of an unconfined version of the Carson Valley model (Niswonger and others, 2011). The unconfined solution presently requires a ten-fold increase in computation time to complete the $35-\mathrm{yr}$ transient simulation and would be difficult to use in model calibration, but the results are compared with those of the calibrated model to assess how the assumption of confined conditions affects the model results.

The heads and flows computed by the unconfined transient simulation are similar to those computed with the confined simulation. For the unconfined transient simulation, the standard errors of weighted residuals in absolute head, waterlevel change, and flow are 16.9, 7.5, and $7.7 \mathrm{ft}$, respectively, indicating a comparable match to observed heads, a better match to water-level change, and a slightly poorer match to observed flows than those obtained with the confined simulation (table 7). The distribution of residuals for the unconfined simulation is also similar to that of the confined simulation. The largest differences between the simulations are in heads computed in Tertiary sediments near the eastern margin of the basin where the unconfined simulation computes much higher values (more than $100 \mathrm{ft}$ higher). Actual heads in these areas are unknown, however, and the difference in the simulated water table between the two simulations is small within $3 \mathrm{mi}$ of well 144 (fig. 29). Water levels computed by the unconfined transient simulation are below the depths of domestic wells specified in some areas, primarily near Johnson Lane and within the Ruhenstroth subdivision. As a result, pumping was not simulated from these domestic wells, and the total volume pumped was reduced by about 2 percent. This reduction has little effect on the simulated groundwater budget, though. The depths of domestic wells in these areas are probably deeper than the depth specified in the model $(150 \mathrm{ft})$. The close agreement between the confined and unconfined transient simulations indicates that the parameter values estimated through model calibration are probably not affected by the assumption of confined conditions.

One alternative model was calibrated through nonlinear regression in which the 800 -ft displacement of Tertiary sediments along the hypothesized Hot Springs Mountain fault was represented by two 400-ft steps: an upper step beneath the eastern boundary of the Quaternary alluvial fan sediments and a lower step along the assumed location of the fault. In this configuration the fluvial sediments extend further eastward beneath the alluvial fan sediments than in the calibrated model. The standard errors of weighted residuals in absolute head, water-level change, and flow are 16.1, 10.4, and $6.9 \mathrm{ft}$, respectively, indicating a comparable match to the observed values as in the calibrated model. The spatial distribution of absolute head residuals differs from that of the calibrated model; however, simulated heads are 20 to $40 \mathrm{ft}$ lower on the eastern side of the basin beneath the alluvial fan sediments and in the Tertiary sediments. The actual geometry of the hypothesized fault is unknown, but these results indicate that eastern areas where heads computed with the calibrated model are over predicted could be underlain by more permeable fluvial sediments that extend eastward from the center of Carson Valley.

Representation of evapotranspiration (ET) from groundwater is another source of uncertainty. The simulated ET rate is determined by four factors in the model: the maximum ET rate $\left(E T_{\max }\right)$, volume of return-flow loss, the irrigation efficiency, and the extinction depth $d_{E T}$ below which ET from the water table does not occur. There is uncertainty associated with the estimates for each of these factors and different combinations of values could be specified to obtain a similar ET rate, so the set chosen for the calibrated model is nonunique. ET simulated by the calibrated model from irrigated land is about $3.7 \mathrm{ft} / \mathrm{yr}$, 23 percent higher than the rate estimated by Maurer and others (2006, p. 22) for irrigated alfalfa and pasture grasses in Carson Valley. Changes to these values would affect the simulated streamflow, but they would have little effect on the relatively flat water table in the center of the valley where the irrigated fields are located.

There are three principal aspects of the calibrated model in which uncertainty in the model design or parameter values are likely to affect important model results: (1) the mountain-front recharge and hydraulic properties of the Tertiary sediments on the eastern side of the basin, (2) the composition of sediments beneath the alluvial fans, and (3) the extent of the confining layer represented within fluvial sediments in the center of the basin. Very little information is available concerning the thickness and hydraulic conductivity of the Tertiary sediments and the position of the water table within them. This information is important because the hydraulic gradient that drives flow through these sediments is determined by these hydraulic properties and by the volume of mountain-front recharge that enters the sediments. It is not possible to calibrate these values without information concerning the position of the water table. Most of the recent and future development in Carson Valley has or will occur on the eastern side of the basin adjacent to areas underlain by Tertiary sediments. The rate of simulated flow through these sediments determines the amount of predicted water-level decline (drawdown) in response to expected increases in pumping. Although the total rate of flow through the Tertiary sediments simulated by the Carson Valley groundwater model is similar to that estimated by the previous PRMS watershed models, the proportion of mountain-front recharge from the Carson Range and the southeastern Pine Nut Mountains is less than that estimated by PRMS models. The uncertainty associated with the volume of mountain-front recharge, and in the hydraulic properties of the Tertiary sediments, limits the reliability of model predictions regarding drawdown along the western and southeastern sides of the valley.

The largest errors in absolute head in the Carson Valley model are in areas underlain by alluvial fans on the east and west sides of the valley where most recent development has occurred. Reducing model error in these areas is important to improving model predictions. For example, heads in alluvial 
fans along the Carson Range are under predicted and the error in absolute head could be reduced by either by decreasing the $K_{x y}$ of the alluvial fan sediments or increasing mountain-front recharge. However, both of these changes result in increased error in flow. The recharge estimate for the Carson Range estimated by PRMS watershed models was more than twice the value estimated through calibration of the Carson Valley groundwater model. This discrepancy reflects the uncertainty in determining this value and indicates that the representation of alluvial fans in the Carson Valley groundwater model could be improved. Little information is available concerning the composition of sediments that underlie the alluvial fans or how the alluvial fan sediments transition to the fluvial sediments in the center of the valley. Additional geologic data in these areas would support an improved conceptual model of deposition in these areas that could be incorporated in the Carson Valley groundwater model to reduce error and reduce uncertainty in the estimation of mountain-front recharge.

Finally, a large degree of vertical anisotropy is required within the fluvial sediments to simulate water-level changes observed at artesian wells in the center of the valley, but the simulated vertical gradient in hydraulic head is over predicted. The actual confining layer is probably not as extensive as that represented, and there are likely areas where no confining layer exists. Additional head data from pairs of shallow and deep wells would provide information concerning the magnitude of the vertical gradient within the valley. Alternatively, additional calibration using regularization with pilot points could be used to better represent the spatial heterogeneity of vertical anisotropy of the fluvial sediments. This parameter limits the hydraulic connection between shallow and deep flow systems in the valley and is important in predicting the extent of drawdown that would result from increased pumping from deep wells in the valley.

\section{Model Application}

The Carson Valley groundwater model was used in a series of five 55 -yr predictive simulations to evaluate the long-term effects of the expected increase in demand for groundwater on water-budget components, groundwater levels, and streamflow in the Carson River. Details of several hypothetical changes were developed in consultation with Douglas County personnel (Mimi Moss, Douglas County Planning; Carl Ruschmeyer and Ron Roman, Douglas County Public Works) and the Carson Water Subconservancy District (Ed James, General Manager).

The predictive simulations represented water years 200660 using 220 quarterly stress periods. The head distribution computed at the end of the calibration simulation was specified as the initial condition, and rates of inflow and outflow specified at model boundaries for the end of the calibration period in water year 2005 were held constant through water year 2010 . The boundary conditions were varied for water years 2011-60 to represent the transition from wet to dry conditions that occurred from water year 1995 through 2004 (fig. 35). This 10 -yr cycle was repeated five times to complete the 55-yr simulation. An alternative approach could have used predictions of climate models to adjust inflow and outflow rates, but such an approach was beyond the scope of the present study.

Four water-use scenarios were compared with a base simulation in which the rates and locations of pumping and surface-water irrigation were based on values specified for water year 2005 and held constant through water year 2060 . Minor changes in the distribution of 2005 pumpage were included in the base scenario to more accurately represent the actual conditions after 2005. Pumpage from Minden wells was increased to compensate for decreased pumpage at Douglas County municipal wells that had previously supplied the Indians Hills, the East Valley water-service area, and parts of the Ruhenstroth water-service area.

Rates of groundwater pumping for municipal and domestic use were increased and the volume of surface water diverted for irrigation was decreased in the four water-use scenarios. In scenario 1 the 2005 municipal pumping rates were increased by 250 percent from 8,800 to 22,200 acre-ft/yr to supply projected population growth (table 10). Additional pumping from 1,340 domestic wells was assumed to occur outside the Douglas County water-service areas from parcels that did not contain wells in 2005. Groundwater pumping for municipal use was increased by a factor of four over the base scenario to 32,900 acre- $\mathrm{ft} / \mathrm{yr}$ in scenario $2 \mathrm{~A}$ to supply the anticipated

Table 10. Future water-use scenarios represented in 55-year predictive simulations.

\begin{tabular}{|c|c|c|c|c|c|c|}
\hline \multirow[b]{2}{*}{ Scenario } & \multirow[b]{2}{*}{$\begin{array}{c}\text { Maximum } \\
\text { irrigated area } 1,000 \\
\text { acres }\end{array}$} & \multicolumn{5}{|c|}{ Pumping, 1,000 acre-feet per year } \\
\hline & & Municipal & Domestic & Agricultural & Other & Total \\
\hline 1 & 40.9 & 22.2 & 5.3 & 7 & 4.6 & 39.1 \\
\hline $2 \mathrm{~A}$ & 40.9 & 32.9 & 5.3 & 7 & 5.0 & 50.2 \\
\hline 3 & 37.2 & 32.9 & 5.3 & 5.3 & 5.2 & 48.7 \\
\hline
\end{tabular}



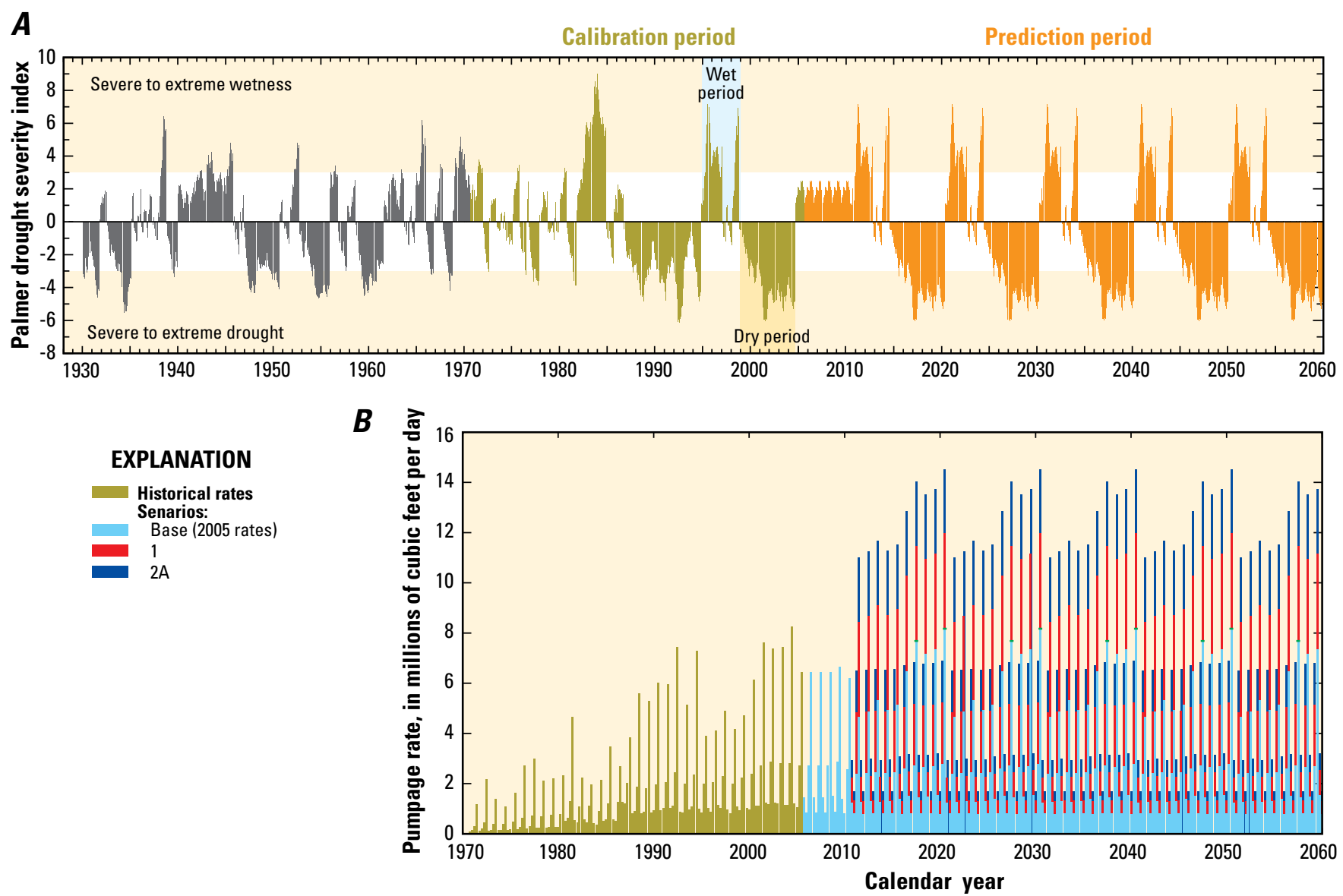

Figure 35. A, Projected Palmer drought severity index; $B$, range in pumping specified in 55-year predictive simulations.

demand associated with the maximum "build-out" of Carson Valley. The same pumping rates were also applied in scenario $2 \mathrm{~B}$, but in water year 2020 pumping was assumed to cease from 2040 domestic wells within Douglas County waterservice areas and pumping at 6 supply wells for the city of Minden was increased to represent a hypothetical reallocation to the municipal water supply. Scenario 3 combined the maximum pumping rates in scenario $2 \mathrm{~A}$ with a removal of 3,700 acres of irrigated land from the water-service areas. Recharge from application of treated effluent for irrigation was applied at the same rates and locations as simulated in 2005 for scenarios 1-3. Although increased municipal pumping would likely generate greater volumes of treated effluent, it is uncertain how or where the effluent may be used in the future.

The greatest increase in pumping is simulated from wells that supplied the town of Minden in 2005 because the Minden wells have the most available water rights and the produced water meets drinking-water standards. Some municipal wells at other locations in Carson Valley produce water that contains arsenic concentrations that do not meet drinking-water standards (Paul and others, 2010, p. 2). Increased municipal pumping was also simulated for municipal wells that supply Gardnerville and the Gardnerville Ranchos and wells owned by Douglas County.

\section{Base Scenario}

The 55-year predictive base scenario indicates that watertable declines will mainly occur along the east side of Carson Valley and near the Gardnerville Ranchos in the south (fig. 36). Declines of more than $40 \mathrm{ft}$ are predicted north of Buckeye Creek in 2060, but most of the predicted declines range from 5 to $40 \mathrm{ft}$. Less than $5 \mathrm{ft}$ of water-table decline is predicted for the central part of Carson Valley and the Johnson Lane area. Water-level declines are predicted to continue through 2060 on the east side of the valley. Model uncertainty precludes the prediction of water-table declines in the upland areas north of Buckeye Creek and east of Fish Spring Flat.

The time-series of annual groundwater budgets indicates that the aquifer system quickly reaches a dynamic equilibrium in the 55-year predictive simulation and reflects the alternating cycles of wet and dry periods (fig. 37). The largest components of the budget are the exchange of groundwater with streamflow, as in the calibration simulation presented earlier. Outflow to evapotranspiration remains relatively constant from year-to-year, but inflows from mountain-front recharge and from storage increase sharply during wet and dry periods, respectively. Outflows to storage also increase during 


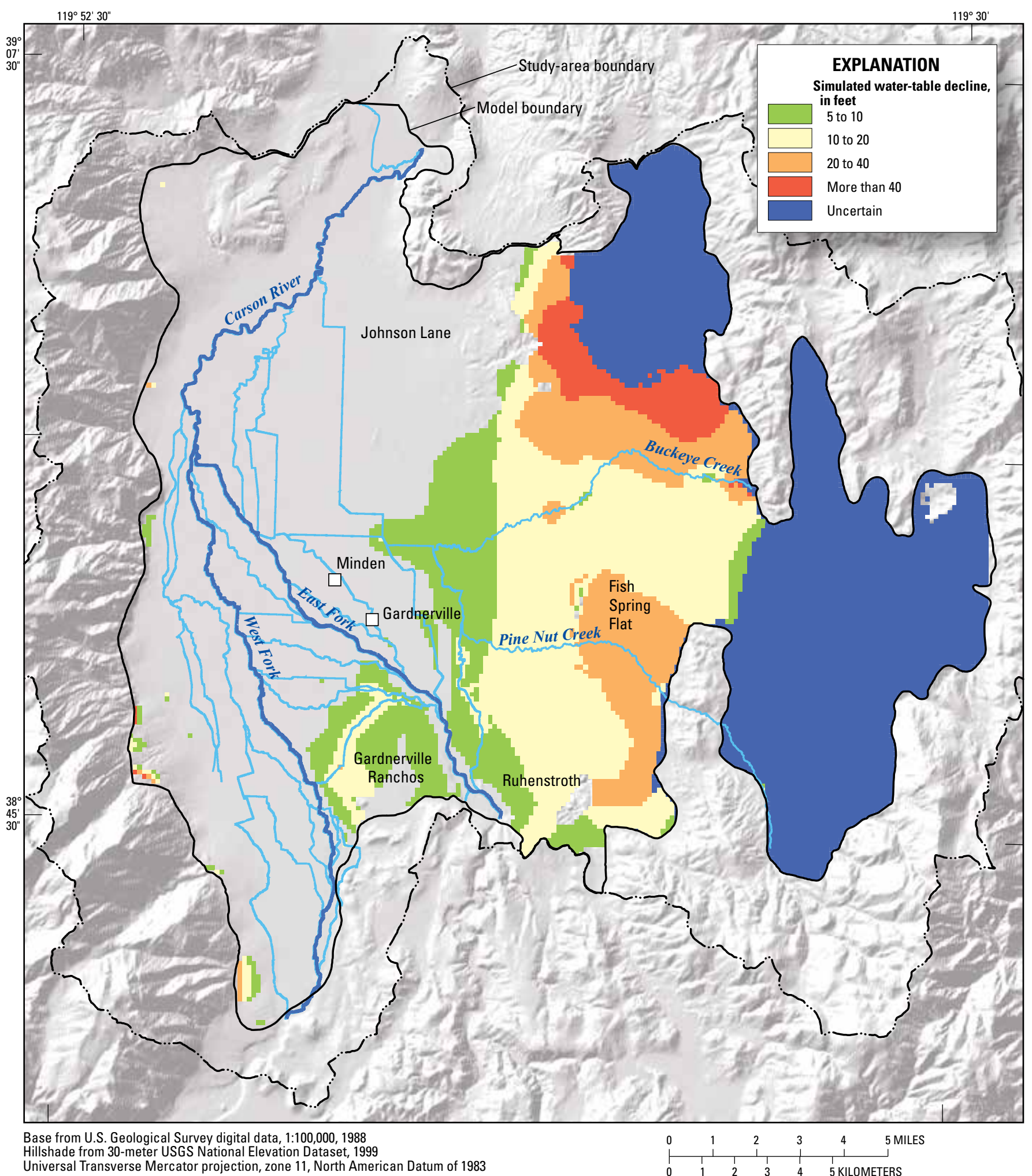

Figure 36. Water-table decline from 2010 through 2060 simulated by the base scenario using the Carson Valley groundwater model. 


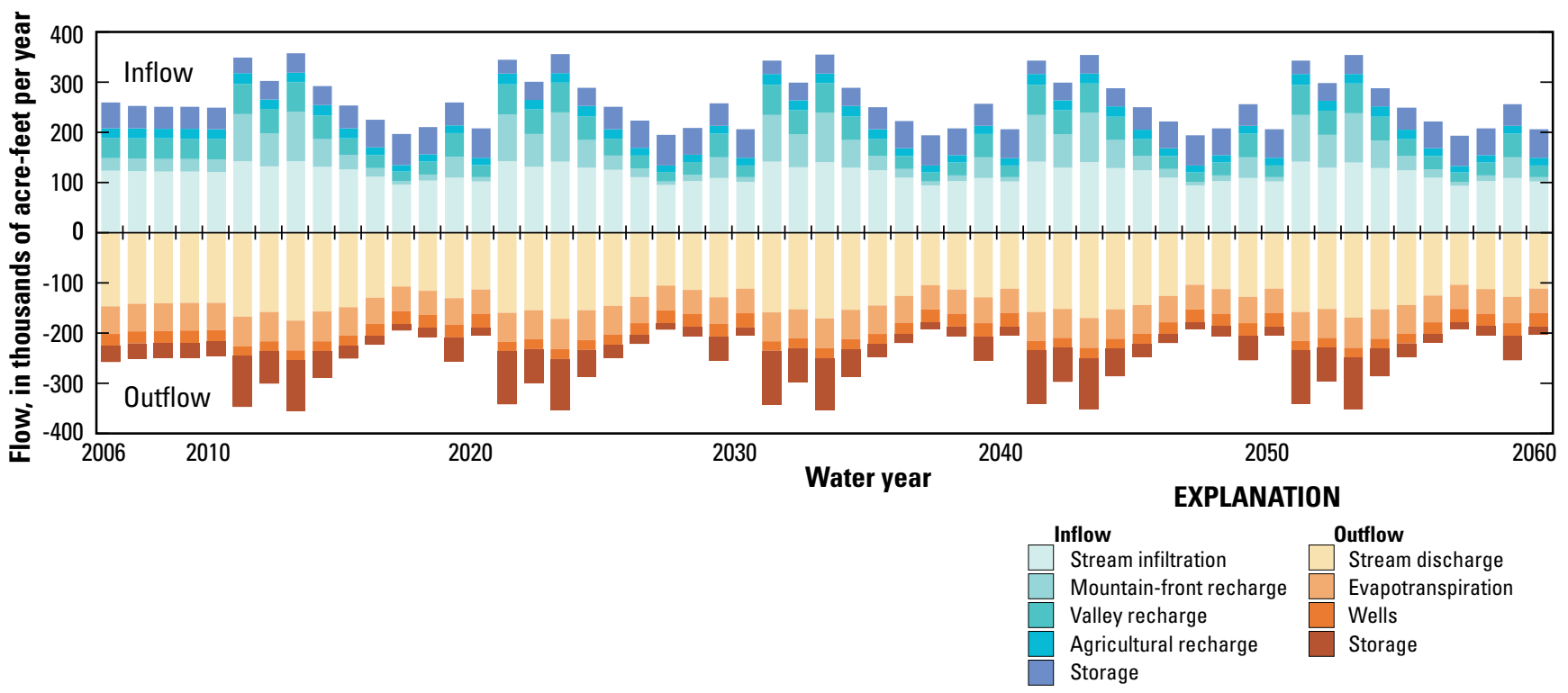

Figure 37. Annual groundwater budgets, 2006-60 simulated by base scenario.

wet periods, while outflow to wells remains a relatively small component of the groundwater budget throughout the 55-year period. The annual loss in downstream flow in the Carson River within Carson Valley is about 38,000 acre-ft.

\section{Scenario 1}

Groundwater withdrawals for municipal and domestic use are 14,600 acre-ft/yr larger in scenario 1 than in the base scenario, as a result of increased pumping at existing municipal wells and the assumed installation of 1,340 new domestic wells. Additional water-level declines, below the levels predicted by the base scenario, are predicted in scenario 1 for the east side of Carson Valley and near the Gardnerville Ranchos (fig. 38). The additional declines range from 5 to $40 \mathrm{ft}$ on the east side of the valley to more than $40 \mathrm{ft}$ near Gardnerville Ranchos, resulting in total water-table declines of as much as $50 \mathrm{ft}$ below 2005 conditions in both areas. Additional waterlevel declines of 5 to $10 \mathrm{ft}$ are also predicted along the western side of the valley, although these declines would be less if estimates of mountain-front recharge from PRMS watershed models were applied. Predicted water-level hydrographs indicate relatively rapid declines at well 144 in Fish Spring Flat and well 29 in Gardnerville Ranchos. Predicted water levels continue to decline through 2060 at the former location, but they stabilize at the latter location (fig. 38). More gradual declines are predicted at wells 55 and 150 on the east side of the valley near Ruhenstroth and Buckeye Creek, respectively. Water-table declines are not indicated by hydrographs predicted for wells in the central part of the valley, but seasonal drawdowns in wells 83 and 113 more than double as a result of the higher pumping rate at the Minden and Gardnerville wells. The higher pumping rate also produces a pronounced downward hydraulic gradient at wells 124 and 125 southwest of Minden, but the upward hydraulic gradient at wells 167 and 175 to the northwest generally is preserved despite the higher pumping rate.

The groundwater budget for scenario 1 is similar to that of the base scenario, but the total flow through the aquifer is slightly larger. For example, in water year 2051 inflows from streams and storage increase by 1,900 and 2,200 acre-ft, respectively (fig. 39A). Outflows to streams and evapotranspiration in water year 2051 decrease by 11,700 and 3,300 acre$\mathrm{ft}$, respectively. The additional decrease in Carson River flow in scenario 1, compared to the base scenario, is 9,600 acre- $\mathrm{ft}$ per year, and accounts for about two-thirds of the increase in pumping (fig. 39B). This result is consistent with that from a previous groundwater-flow model of Carson Valley developed by Maurer (1986) that indicated 70 to 75 percent of pumped water was derived from a decrease in outflow of the Carson River.

\section{Scenarios 2A and 2B}

Groundwater withdrawals for municipal and domestic use are 25,300 acre-ft/yr more in scenario $2 \mathrm{~A}$ than in the base scenario as a result of increased pumping at existing municipal wells. The installation of 1,340 new domestic wells is assumed, as in scenario 1 . Total groundwater withdrawals are the same in scenario $2 \mathrm{~B}$ as in scenario $2 \mathrm{~A}$, but in water year 2020 pumping from 2,040 domestic wells ceases and pumping from 6 municipal wells increases in scenario $2 \mathrm{~B}$. Areas of additional water-level decline (below the levels predicted by the base scenario) are more extensive on the east side of the valley by 2060 in scenario $2 \mathrm{~A}$ than in scenario 1 , resulting in total water-table declines of $60 \mathrm{ft}$ below 2005 conditions. 

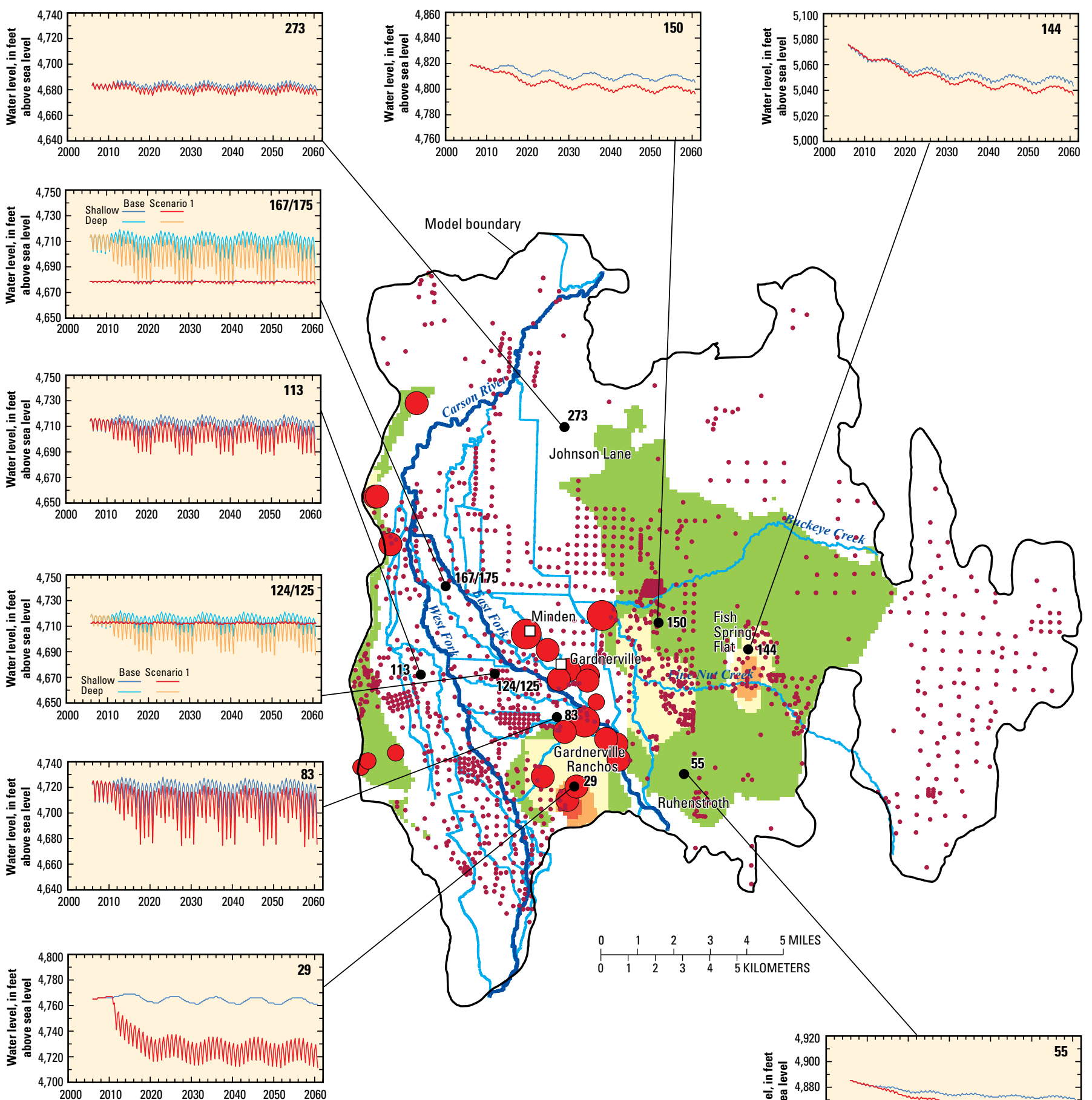

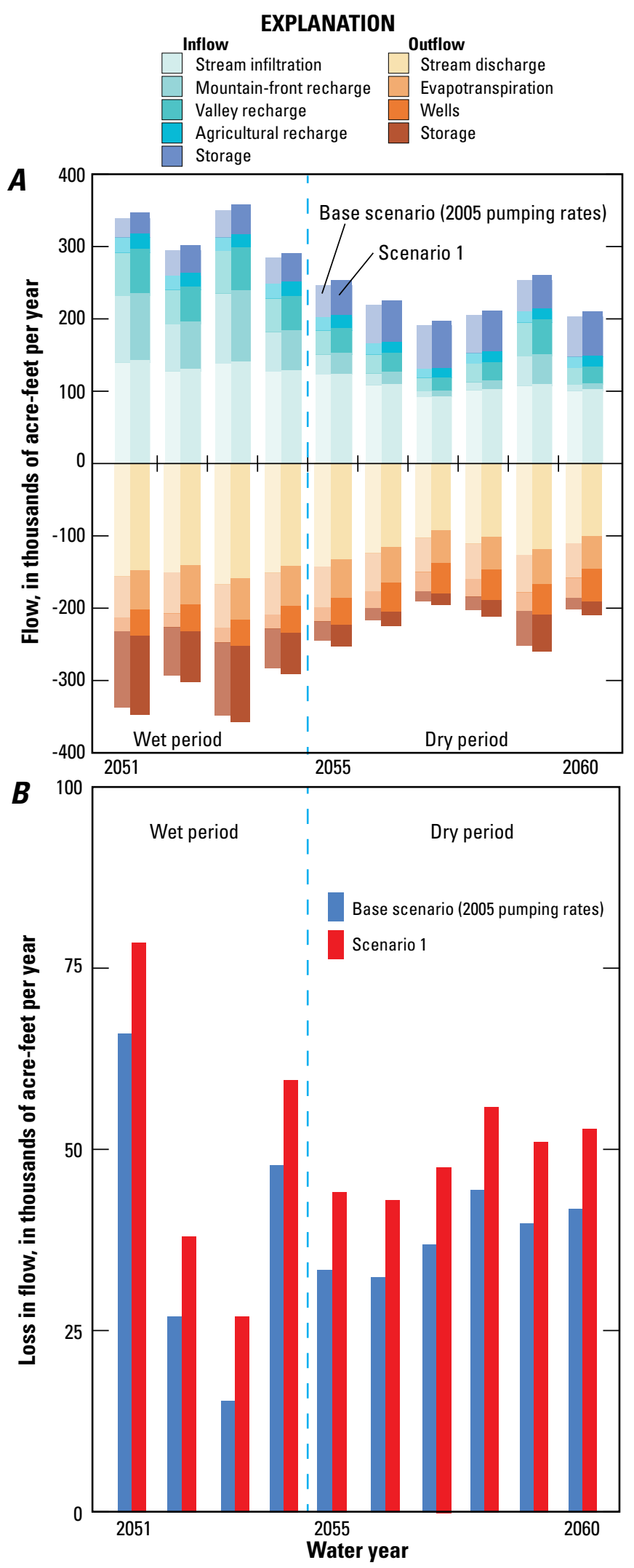

Figure 39. $A$, Annual groundwater budgets from 2051 through 2060 simulated by base scenario and scenario $1 ; B$, annual loss in flow in the Carson River, 2051-60 predicted by base scenario and scenario 1.
Additional water-level declines from 5 to $40 \mathrm{ft}$ (below the levels predicted by the base scenario) are also predicted in scenario $2 \mathrm{~A}$ on the west side of the valley (fig. 40). Additional water-level declines in scenario $2 \mathrm{~B}$ are similar to those in scenario $2 \mathrm{~A}$, but not as extensive in areas where pumping from domestic wells ceases in 2020 (fig. 41).

Predicted water-level hydrographs in scenarios $2 \mathrm{~A}$ and 2B are similar and indicate as much as $10 \mathrm{ft}$ of additional drawdown at wells 83 and 113 in the central part of the valley compared to the base scenario (figs. 40, 41). The upward hydraulic gradient at wells 167 and 175 northwest of Minden is also reduced. Total flow through the aquifer is larger in scenario $2 \mathrm{~A}$ than in the base scenario. In water year 2051 inflows from streams and storage increase by 3,700 and 3,900 acre-ft, respectively, while outflows to streams and evapotranspiration decrease by 19,400 and 5,600 acre-ft, respectively (fig. $42 \mathrm{~A}$ ). The decrease in mean-annual Carson River flow in scenario $2 \mathrm{~A}$ is 16,300 acre-ft more than in the base scenario, and accounts for about 60 percent of the increase in pumping (fig. $42 B$ ). The annual groundwater budgets are nearly identical for scenarios $2 \mathrm{~A}$ and $2 \mathrm{~B}$, but there is a slightly greater decrease in Carson River flow (16,500 acre- $\mathrm{ft}$ ) in scenario 2B (figs. $43 A, B$ ).

\section{Scenario 3}

Groundwater withdrawals for municipal and domestic use are the same in scenario 3 as in scenario $2 \mathrm{~A}$, but the maximum irrigated acreage is reduced about 13 percent by 3,700 acres in 2010. The predicted distribution of water-table decline is similar to that predicted by scenario $2 \mathrm{~A}$, but slightly more decline is predicted south of Johnson Lane where irrigation ceases (figs. 40, 44). Diversions of streamflow for irrigation in scenario 3 average 10,100 acre-ft/yr less than in scenario $2 \mathrm{~A}$. In water year 2051 total flow through the aquifer is 5,100 acre-ft less in scenario 3 than in scenario 2A (fig. 45A). The predicted decrease in mean-annual Carson River flow in scenario 3 is only 6,500 acre-ft/yr less than in the base scenario (fig. 45B). 

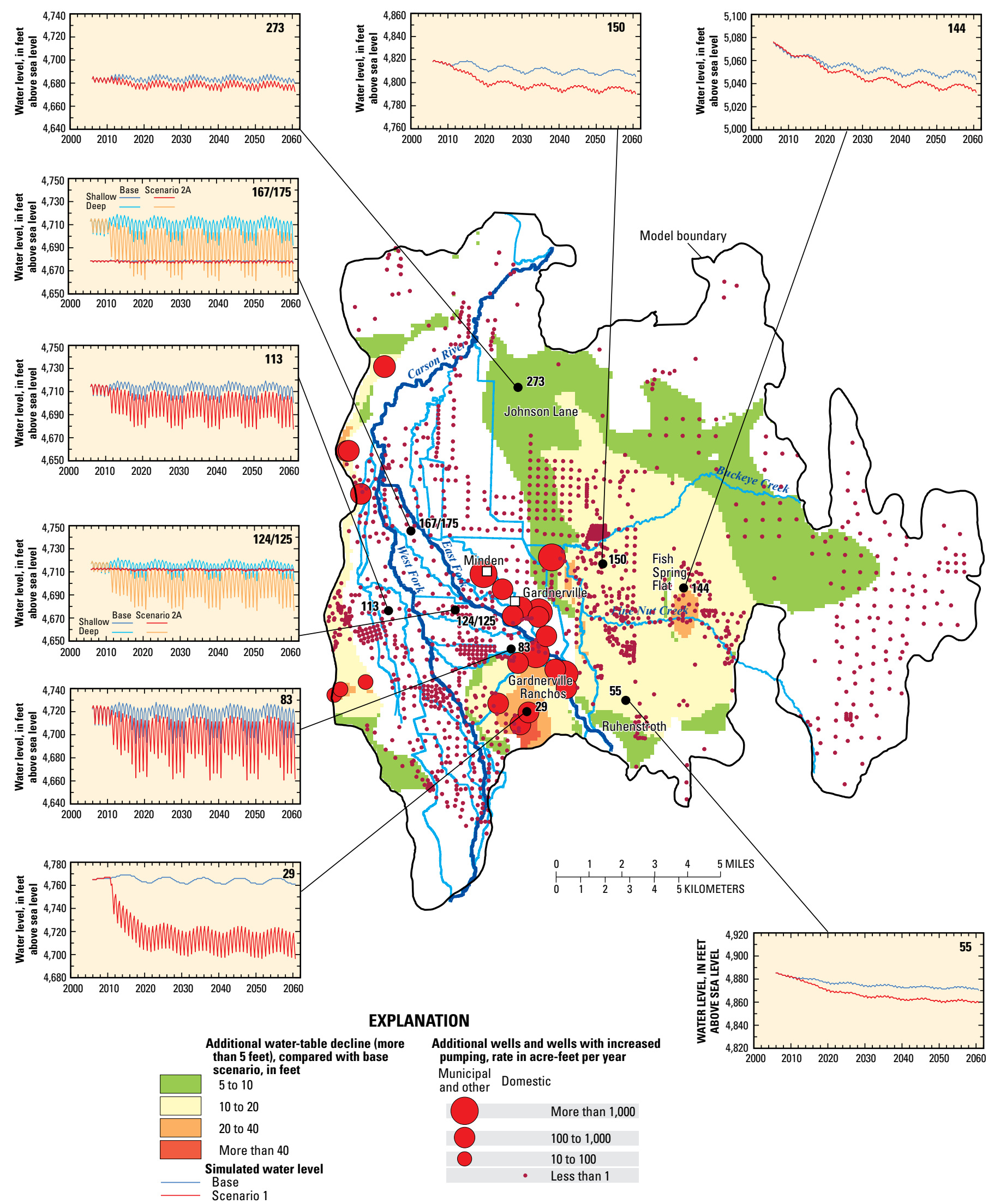

\section{EXPLANATION}

Additional wells and wells with increased pumping, rate in acre-feet per year Municipal Domestic
and other and other
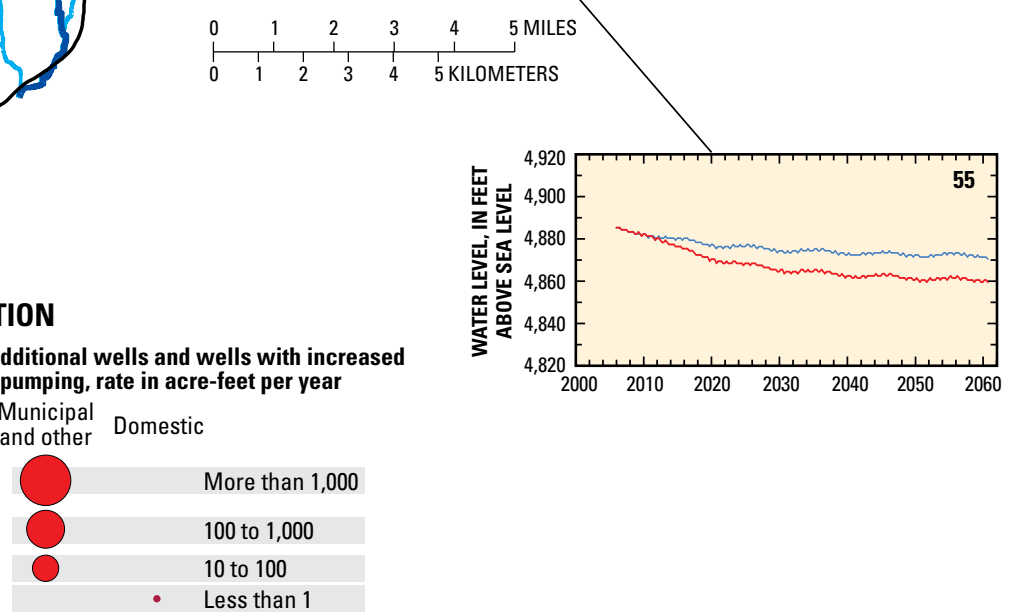

del boundary 

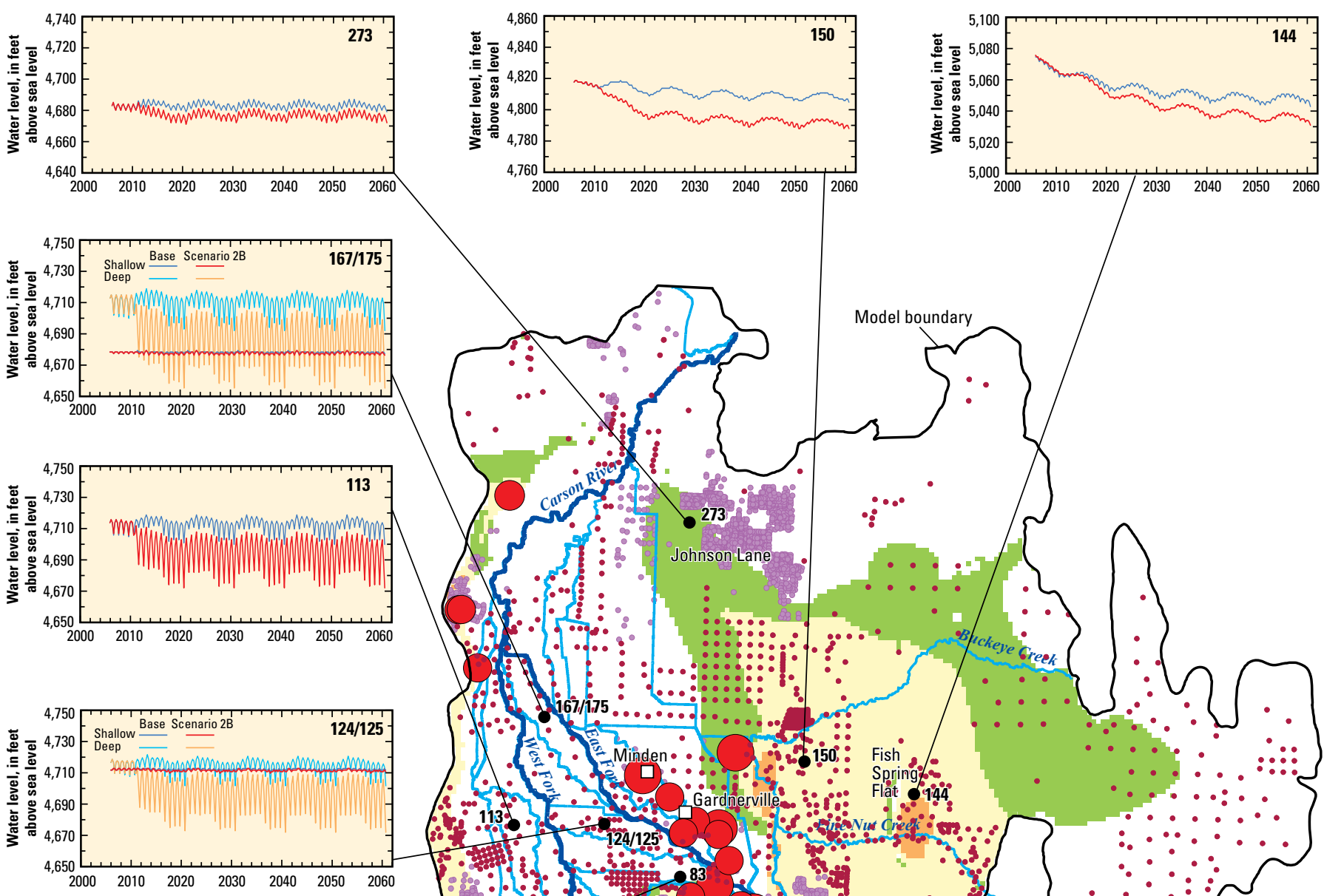


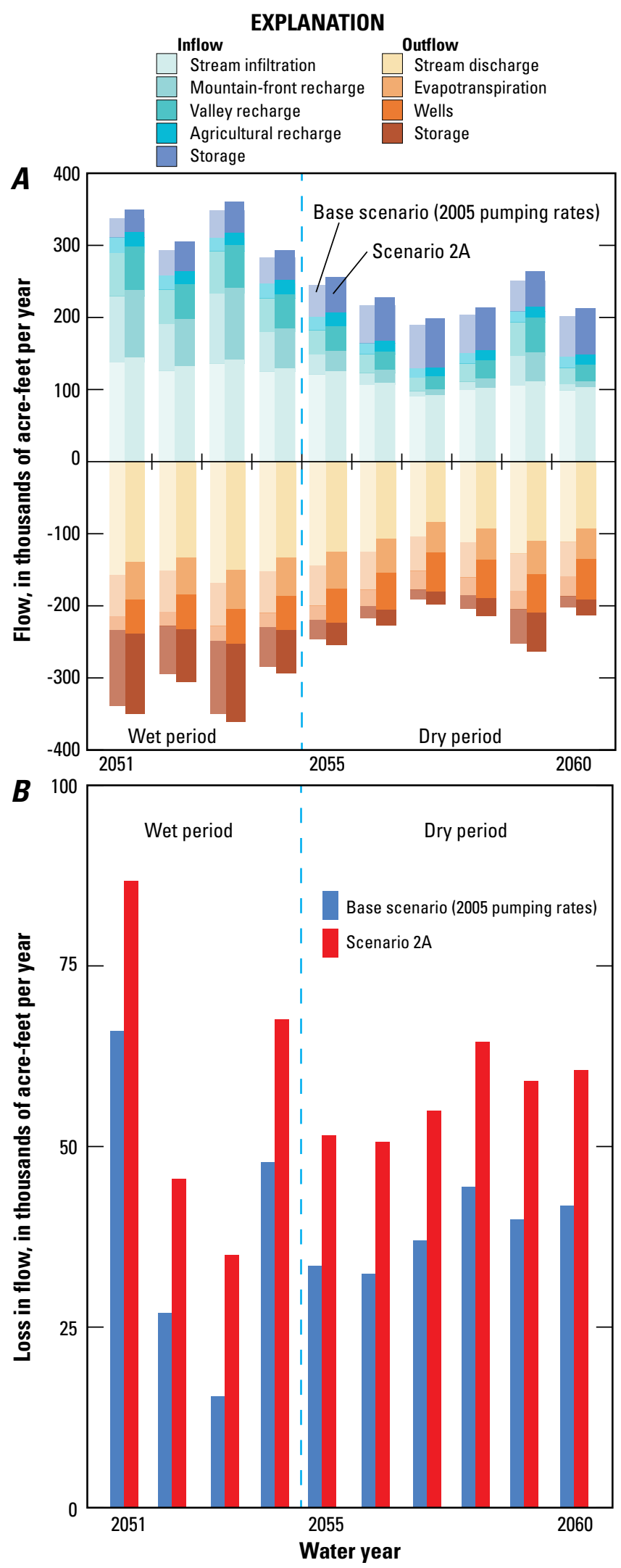

Figure 42. $A$, Annual groundwater budgets, 2051-60 simulated by base scenario and scenario $2 A ; B$, annual loss in flow in the Carson River, 2051-60 predicted by base scenario and scenario $2 \mathrm{~A}$.

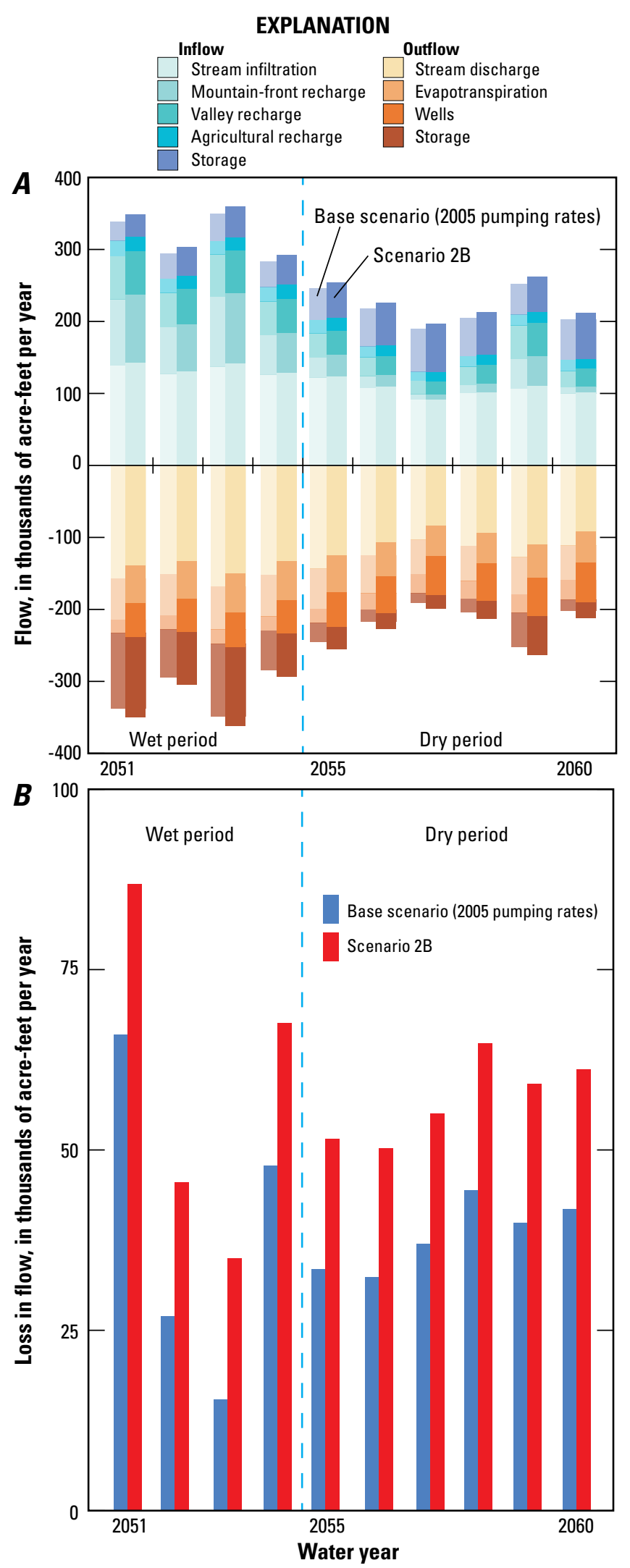

Figure 43. $A$, Annual groundwater budgets, 2051-60 simulated by base scenario and scenario $2 \mathrm{~B} ; B$, annual loss in flow in the Carson River 2051-60 predicted by base scenario and scenario $2 \mathrm{~B}$. 

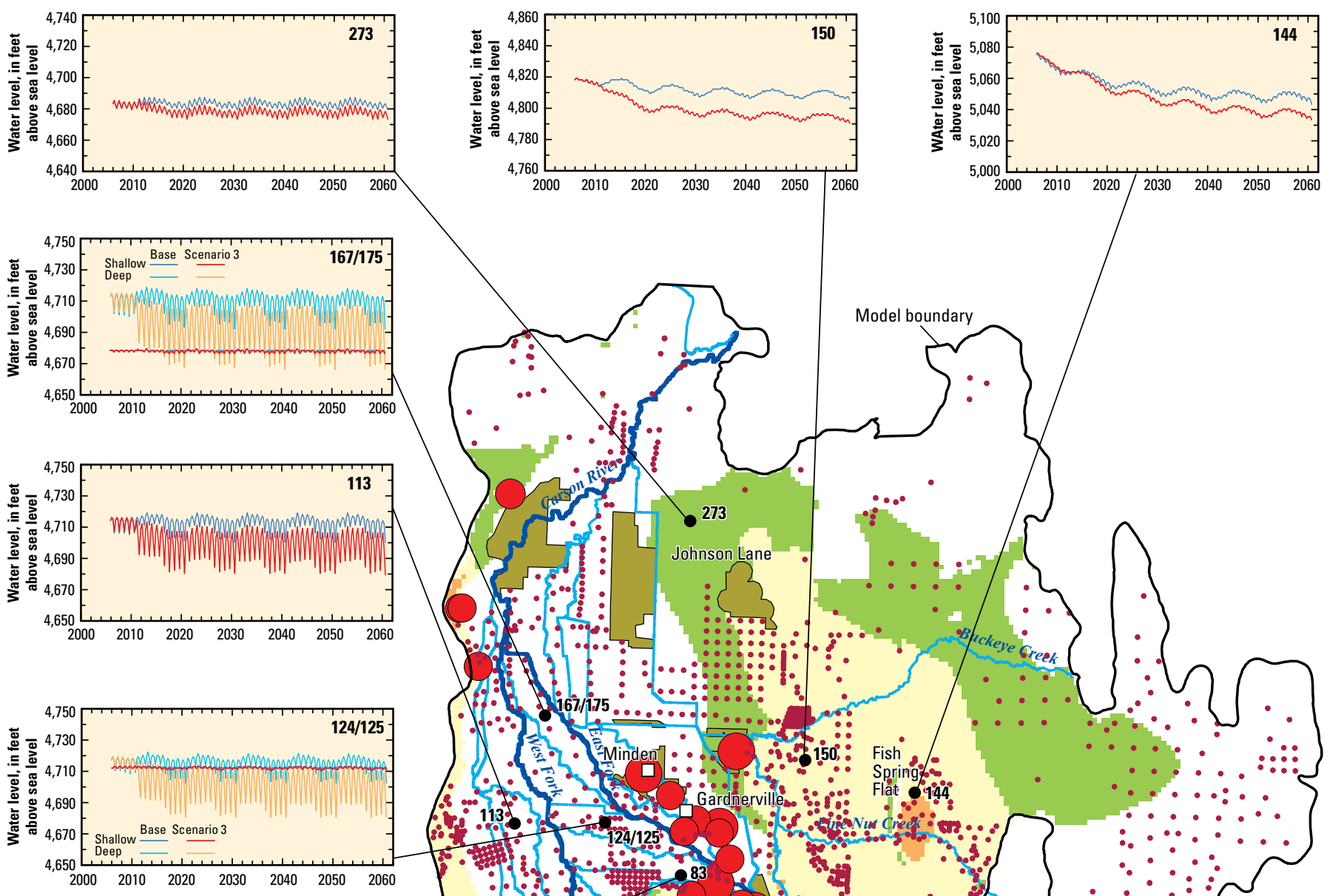

del boundary
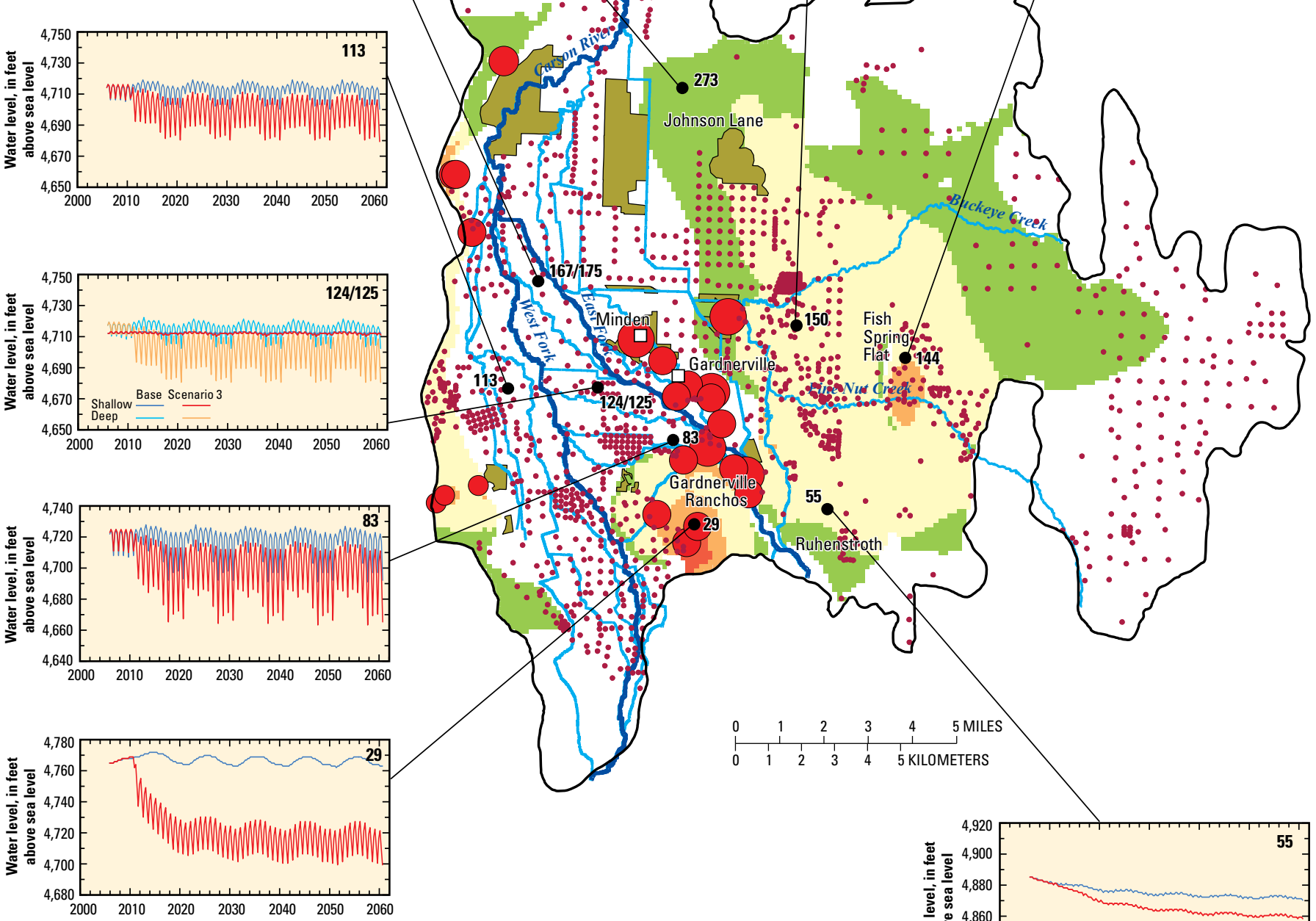

\section{EXPLANATION}

Additional water-table decline (more than 5 feet), compared with base scenario, in feet

Additional wells and wells with increased pumping, rate in acre-feet per year

$$
\text { Municipal }
$$
Domestic 10 to 20 20 to 40 More than 40

Agricultural land removed from irrigation Simulated water level and other

More than 1,000

100 to 1,000

10 to 100 Less than 1

Figure 44. Additional groundwater withdrawals included in scenario 3 , agricultural land removed from irrigation, additional water-table decline 2010-60 simulated by scenario 3, and simulated water-level hydrographs at selected wells for base scenario and scenario 3 . 

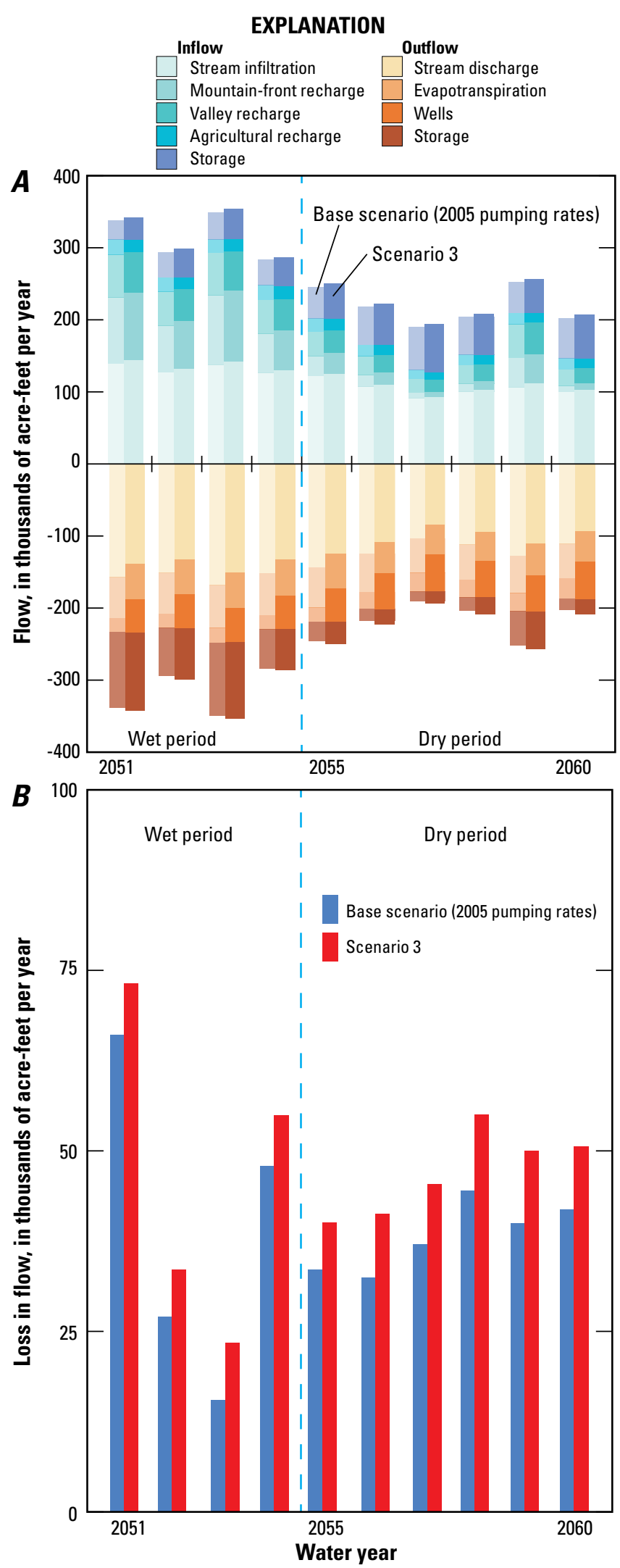

Figure 45. $A$, Annual groundwater budgets, 2051-60, simulated by base scenario and scenario $3 ; B$, annual loss in flow in the Carson River 2051-60 predicted by base scenario and scenario 3 .

\section{Prediction Uncertainty}

The 55-yr predictive simulations indicate that continued withdrawals of groundwater at the rates estimated for 2005 (base scenario) would result in about 5 to $40 \mathrm{ft}$ of water-table declines on the eastern side of Carson Valley and near Gardnerville Ranchos by 2060. Increasing groundwater withdrawals to meet the maximum expected water-demand (scenario 2A) would widen the extent of water-level declines on the east side of Carson Valley, ranging from 5 to $60 \mathrm{ft}$, and produce declines from 5 to $40 \mathrm{ft}$ on the western side of the valley. However, the predicted declines on the western side of the valley would be less if values of mountain-front recharge derived from the PRMS watershed models were specified. The water table in the central part of the valley near the Carson River and the irrigation system would remain essentially unchanged under either withdrawal scenario, but heads in the deeper, confined part of the aquifer would decline as much as $30 \mathrm{ft}$. The increased groundwater withdrawals would be met primarily by decreased flow in the Carson River and would result in larger losses in streamflow than typically were observed under 2005 conditions. However, there is uncertainty in the actual amount of decreased flow because of potential changes in future irrigation practices not accounted for in the model. For example, if greater amounts of treated effluent were used for irrigation of land previously irrigated from river diversions, the decrease in river flow would be less. Part of the additional groundwater demand would also be met by the loss of groundwater storage, as water levels are projected to continue to decline after 2060 in both scenarios.

The projections of the predictive simulations are sensitive to rates of mountain-front recharge specified for the Carson Range and the Pine Nut Mountains. As discussed earlier, recharge rates previously estimated by PRMS watershed models were adjusted during calibration of the groundwater model; this adjustment resulted in a reduction of 12,000 acre$\mathrm{ft} / \mathrm{yr}$ of recharge from the Carson Range and little change in recharge from the Pine Nut Mountains. The areas of projected water-table decline on the west and east sides of Carson Valley are adjacent to these uplands, so uncertainty in the specified recharge rates results in uncertainty in the predicted declines. The projected area of water-table decline along the west side of the valley is confined to a narrow band between the Carson Range and the Carson River, but a much wider area of watertable decline is projected for the east side of Carson Valley. Little information is available on the east side of the valley that could constrain estimates of mountain-front recharge, such as the position of the water table or the hydraulic properties of the Tertiary sediments that underlie this area.

Mountain-front recharge rates in the predictive simulations are assumed to remain within the range of extreme rates observed in the past 35 years. The sensitivity of predicted water-table declines to rates of mountain-front recharge was assessed through an alternate scenario in which the same withdrawal rates were specified as in scenario $2 \mathrm{~A}$, but recharge rates were decreased by 50 percent along the Pine 
Nut Mountains. These changes resulted in water-table declines ranging from 5 to $60 \mathrm{ft}$ on the east side of Carson Valley, and declines of more than $60 \mathrm{ft}$ in areas east of Fish Spring Flat. For example, predicted declines by water year 2060 at wells 150 and 144 were 21 and $56 \mathrm{ft}$ greater than in scenario $2 \mathrm{~A}$ (fig. 40). Although it is unlikely that average recharge rates would abruptly decrease by 50 percent, recharge rates could be reduced by either decreased precipitation or increased evapotranspiration in the future as a result of changing global weather patterns (Jeton and others, 1996; Dettinger and others, 2004). Additional predictive scenarios could be run using recharge rates based on projections of climate models that take into account these possible changes in recharge. A prudent management approach would include continued monitoring of water levels on both the east and west sides of Carson Valley to either verify the predictions of the groundwater flow model or to provide additional data for recalibration of the model if the predictions prove inaccurate.

\section{Summary}

Rapid growth and development within Carson Valley in Douglas County, Nevada, and Alpine County, California, has caused concern over the continued availability of groundwater and whether the increased municipal demand could either impact the availability of water or result in decreased flow in the Carson River. A groundwater-flow model was developed in this study to provide estimates of the groundwater-budget components for Carson Valley and to evaluate the potential effects of changes in water use on groundwater levels in Carson Valley and on flow in the Carson River downstream from Carson Valley.The model provides a tool that can be used to aid water managers and planners in making informed decisions.

\section{Hydrogeology}

Carson Valley is underlain by semi-consolidated Tertiary sedimentary deposits as much as 3,000-ft thick that are overlain by Quaternary alluvial fans and fluvial sediments (basin fill) deposited by the Carson River and its tributaries. The Tertiary sediments are assumed to have been down-dropped about 800 feet along the hypothesized Hot Springs Mountain fault on the eastern side of the basin. The hydrology of Carson Valley is dominated by streamflow in the Carson River that is diverted across the valley floor through a network of unlined canals, ditches, and sloughs for flood irrigation of about 39,000 acres and maintains a shallow water table less than $5 \mathrm{ft}$ beneath much of the valley floor. Average streamflow entering the valley was 344,100 acre-ft/yr, while average flow exiting the was 297,400 acre-ft/yr. Total streamflow from perennial watersheds in the Carson Range is estimated as 30,000 acre$\mathrm{ft} / \mathrm{yr}$, while mountain-front recharge is estimated as 20,000 and 16,000 acre-ft/yr from west and east sides of the valley,
respectively.Sources of irrigation water include the Carson River, runoff from perennial watersheds draining the Carson Range, groundwater pumped from Quaternary sediments, and wastewater effluent imported from the Lake Tahoe basin and generated within Carson Valley. Annual pumping of groundwater has increased from less than 10,000 acre-ft in the 1970s to about 31,000 acre-ft in 2004; municipal use of groundwater was about 10,000 acre-ft in 2000.

Median transmissivities computed from specific-capacity data for Quaternary alluvial fan, Quaternary fluvial, and Tertiary sediments are $316 ; 3,120$; and $110 \mathrm{ft}^{2} / \mathrm{d}$, respectively, with larger transmissivity values in the central part of the valley underlying the East and West Forks of the Carson River and smaller values near the valley margins. Values of specific yield in Carson Valley are typically 15 percent, with values greater than 20 percent near the center of the valley, and values of 10 percent around the margins of the valley. Groundwater flows from the west and east toward the Carson River and then north toward the outlet of the Carson Valley. An upward hydraulic gradient exists over much of the valley, and artesian flow occurs in some areas, but a continuous confining unit is not thought to underlie the entire valley. The exchange of water between groundwater and streams changes from wet to dry years and during the irrigation season. Losses of flow from the Carson River and the irrigation system to groundwater occur mainly in the southeastern part of the valley, while discharge of groundwater to the river occurs on the north and west sides of the valley. Most of the aquifer is in a state of dynamic equilibrium, and groundwater levels fluctuate in response to both seasonal and annual variations in recharge and pumping, but water levels have declined 10 to $15 \mathrm{ft}$ on the eastern side of the valley. Inflow and outflow to the Carson River account for more than two-thirds of the total budget, with a net loss of 51,000 acre-ft/yr from the river within Carson Valley. Pumped groundwater accounts for only 4.4 percent of the total budget.

\section{Groundwater-Flow Model}

A model that simulates groundwater flow through Quaternary and Tertiary sediments in Carson Valley was designed and calibrated to historical conditions from water years 1970 through 2005. The 35-yr transient simulation represented quarterly changes in precipitation, streamflow, pumping, and irrigation. The $242.8-\mathrm{mi}^{2}$ model domain is discretized with a 550-ft grid and divided into 10 model layers that range in thickness from 80 to $900 \mathrm{ft}$. The top three model layers represent alluvial fan and fluvial sediments; the bottom seven layers primarily represent Tertiary sediments that are exposed on the eastern side of the valley and dip beneath the Quaternary sediments to the west.

The top model boundary represents recharge derived from precipitation and irrigation, and evapotranspiration from vegetation. Recharge is represented in areas irrigated with water from the 12 perennial streams that drain the Carson Range, 
effluent wastewater, and from the Carson River and the adjoining irrigation system. Recharge is also applied to the model domain using wells to represent infiltration of septic-tank discharge and groundwater inflow from perennial and ephemeral watersheds in the Carson Range and Pine Nut Mountains. Discharge wells represent pumping of groundwater for municipal, domestic, irrigation, and other water supplies. The exchange of water between groundwater and the irrigation system was represented with a version of the Streamflow Routing (SFR2) package that was modified to apply diversions from the irrigation network to irrigated areas as recharge.

The Quaternary sediments were divided into five zones representing the four alluvial fans and the fluvial sediments. The horizontal hydraulic-conductivity $\left(K_{x y}\right)$ values for Tertiary sediments were estimated for five zones delineated on the basis of geology mapped by Muntean (2001). Vertical anisotropy values $\left(K_{x y} / K_{z}\right)$ were estimated for the eastern and western alluvial fans, the fluvial sediments and three Tertiary zones. Horizontal anisotropy $\left(K_{x} / K_{y}\right)$ was specified for the western alluvial fan to represent preferred flow paths in the direction of deposition from the front of the Carson Range eastward to Carson Valley. The aquifer system was assumed to be confined, but the hydraulic conductivity of the top active model layers that intersect the water table was multiplied by a factor to account for partial saturation. A power function was used to decrease the horizontal hydraulic-conductivity below threshold depths of 500 and $200 \mathrm{ft}$ for the Quaternary and Tertiary sediments, respectively. A specific yield $\left(S_{y}\right)$ value of 0.1 was specified for Tertiary sediments; three $S_{y}$ values ranging from 0.1 to 0.3 were specified for Quaternary sediments (the eastern and western alluvial fans and the fluvial sediments). Storage values representative of specific yield were specified in parts of model layers where unconfined conditions are assumed to occur.

The groundwater-flow model was calibrated with UCODE to estimate values of hydraulic conductivity, recharge, and streambed hydraulic-conductivity that minimized the difference between simulated groundwater levels and streamflows with 5,686 water levels measured in 237 wells and flow at 5 streamflow-gaging stations. The model simulates the groundwater system reasonably well, and the standard error (SE) in absolute head is $37 \mathrm{ft}$ or 3 percent of the 1,090-ft measured range, while the SE in water-level change is $5.8 \mathrm{ft}$ or 9 percent of the $68-\mathrm{ft}$ measured range. Observed water-level declines on the eastern side of the valley are well simulated, although the absolute head in some areas is either over-or underpredicted. The SE of the weighted residuals for flows is $6.7 \mathrm{ft}$.

A total of 41 parameters were specified in the groundwatermodel, 18 of which were optimized through nonlinear regression. Parameter sensitivities are highest for the hydraulic conductivity and recharge parameters associated with the Tertiary sediments in the northern part of the basin, and they are lowest for the Tertiary vertical-anisotropy parameters and streambed hydraulic-conductivity parameters for the Carson River. The mean transmissivity $(T)$ values computed from optimized values of $K_{x y}$ parameters $\left(11,000\right.$ and $800 \mathrm{ft}^{2} / \mathrm{d}$ for the fluvial and alluvial-fan sediments, respectively) are both within the third quartile of $T$ values estimated from specific-capacity data. Optimized streambed hydraulic-conductivity values are larger for channels in lowlands near the center of the valley and smaller for channels in the uplands. The optimized $K_{x y}$ values for Tertiary sediments ( 3.5 to $13 \mathrm{ft} / \mathrm{d}$ ) yield transmisivity values that are larger than the third quartile of $T$ values estimated from specific-capacity data. An alternate regression indicated that more reasonable $K_{x y}$ values for Tertiary sediments $(2 \mathrm{ft} / \mathrm{d}$ ) would produce a model that slightly better matches heads and flows at the expense of a poorer match to water-level fluctuations. The estimated vertical anisotropy for the Quaternary fluvial sediments is large $(9,900)$, but this value is comparable to the value estimated for the previous model of Carson Valley. Observed water-level changes in artesian wells are not well simulated with smaller values. Volumes of mountainfront recharge estimated by the regression are comparable to estimates from PRMS watershed models, but about 70 percent of the mountain-front recharge in the groundwater model enters along the Pine Nut Mountains, while the PRMS models estimated a nearly equal distribution of recharge between the Carson Range and the Pine Nut Mountains.

Simulated flow paths indicate that groundwater flows faster through the center of Carson Valley where the hydraulic conductivity of fluvial sediments is higher and slower through the lower hydraulic-conductivity Tertiary sediments to the east. Shallow flow in the center of the valley is towards drainage channels; deeper flow is generally directed toward the basin outlet to the north. Simulated groundwater budgets indicate that stream infiltration and mountain-front recharge are the largest inflow components, while stream discharge and evapotranspiration are the largest outflow components. Pumping has historically been less than 15 percent of the groundwater budget, while agricultural recharge has been less than 10 percent. The aquifer system is in a dynamic equilibrium with large inflows from storage in dry years and large outflows to storage in wet years.

Uncertainty in simulation results primarily originates from errors in model design and parameter values that cause errors in simulated heads and flows and is a reflection of the current state of knowledge regarding the aquifer system. The uncertainty related to the assumption of confined conditions for an unconfined aquifer system was assessed by using a recently available (May 2011) numerical solver to simulate the aquifer system as unconfined. The model errors in the confined and unconfined simulations were comparable and indicate that the parameter values estimated through model calibration are largely unaffected by the assumption of confined conditions.

There are three principal aspects of the calibrated model in which uncertainty is likely to affect important model results: (1) the hydraulic characteristics of the Tertiary sediments on the eastern side of the basin, (2) the composition of sediments beneath the alluvial fans, and (3) the extent of the confining layer represented within fluvial sediments in the center of the basin. Most of the development in Carson Valley has or will occur on the eastern side of the basin where very little 
information is available concerning the hydraulic properties of the Tertiary sediments or the position of the water table. The largest errors in absolute head are in areas underlain by alluvial fans on the east and west sides of the valley where little information is available concerning the composition of sediments that underlie the alluvial fans. Finally, the actual confining layer underlying the center of the valley is probably not as extensive as that represented. The confining-layer extent limits the hydraulic connection between shallow and deep flow systems and determines the extent of drawdown that would result from increased pumping at deep wells. Additional information in these three areas would improve the current state of knowledge concerning the aquifer system and serve to reduce model uncertainty.

\section{Model Application}

The Carson Valley groundwater model was used in a series of 55-yr predictive simulations to evaluate the long-term effects of the expected increasing demand for water on waterbudget components, groundwater levels, and streamflow in the Carson River. The predictive simulations represented water years 2006-60 using 220 quarterly stress periods. The initial heads were specified from the distribution computed at the end of the calibration simulation, and boundary conditions were varied cyclically to represent the transition from wet to dry conditions that occurred from water year 1995 through 2004. Four water-use scenarios were compared with a base simulation in which the rates and locations of pumping and surfacewater irrigation specified for water year 2005 were held constant through water year 2060. The four scenarios included: (1) total pumping rates increased by 70 percent, including an additional 1,340 domestic wells, (2A) total pumping rates more than doubled with municipal pumping increased by a factor of four, (2B) maximum pumping rates of $2 \mathrm{~A}$ with 2,040 fewer domestic wells, and (3) maximum pumping rates of $2 \mathrm{~A}$ with 3,700 acres removed from irrigation.

Continued pumping at 2005 rates resulted in water-level declines of 5 to $40 \mathrm{ft}$ on the east side of Carson Valley by 2060 with less than $5 \mathrm{ft}$ of decline in the central part of the valley. Increasing pumping by 16,200 acre-ft/yr in scenario 1 caused additional water-table declines (compared with the base scenario) of 5 to $10 \mathrm{ft}$ on the east side of the valley and more than $40 \mathrm{ft}$ near Gardnerville Ranchos, resulting in as much as 50-ft declines below 2005 conditions in both areas. Steep declines in water levels are predicted for Fish Spring Flat and Gardnerville Ranchos that would continue through 2060, and the additional reduction in mean-annual Carson River flow $(9,600$ acre-ft) accounts for two-thirds of the increase in pumping. Increasing pumping by 27,300 acre- $\mathrm{ft} / \mathrm{yr}$ in scenario $2 \mathrm{~A}$ relative to the base scenario caused more extensive water-table declines with as much as $60 \mathrm{ft}$ of decline in Fish Spring Flat and Gardnerville Ranchos, and as much as $40 \mathrm{ft}$ of decline on the west side of the valley. The additional reduction in meanannual Carson River flow in scenario 2A (16,300 acre-ft) over the base scenario accounts for 70 percent of the increase in pumping. There was little difference between simulation results for scenarios $2 \mathrm{~A}$ and $2 \mathrm{~B}$, except for slight reduction in Carson River flow of 200 acre-ft/yr in scenario 2B. Reducing irrigated acreage by 13 percent in scenario 3 caused slightly more water-table decline south of Johnson Lane where irrigation ceases, but the Carson River flow was only 6,500 acre-ft less than in the base scenario.

The 55-yr predictive simulations indicate that increasing groundwater withdrawals to meet the maximum expected water-demand would result in 40 to $60 \mathrm{ft}$ of water-table decline on the west and east sides of Carson Valley, respectively. The water table in the central part of the valley would remain essentially unchanged, but as much as $30 \mathrm{ft}$ of head decline is expected in the confined deeper parts of the aquifer. The increased withdrawals would be offset primarily by decreased flow in the Carson River and by the loss of groundwater storage. There is uncertainty in the actual amount of decreased flow because of potential changes in irrigation practices not accounted for in the model such as an increased use of treated effluent for irrigation. The projections of the predictive simulations are sensitive to rates of mountain-front recharge specified for the Carson Range and the Pine Nut Mountains. For example, reducing the recharge rate by 50 percent resulted in $60 \mathrm{ft}$ more decline in Fish Spring Flat than predicted by scenario $2 \mathrm{~A}$. Little information, such as the position of the water table or the hydraulic properties of the Tertiary sediments, is available on the east side of the valley where the most extensive areas of water-table decline are predicted. A prudent management approach would include continued monitoring of water levels on both the east and west sides of Carson Valley to either verify the predictions of the groundwater flow model, or to provide additional data for recalibration of the model if the predictions prove inaccurate. 


\section{References Cited}

Allander, K.P., Smith, J.L., and Johnson, M.J., 2009, Evapotranspiration in the lower Walker River basin, west-central Nevada: U.S. Geological Survey Scientific Investigations Report 2009-5079, 62 p., also available at http://pubs.usgs. gov/sir/2009/5079/.

Alvarez, N.L., and Seiler, R.L., 2004, Sources of phosphorus to the Carson River upstream from Lahontan Reservoir, Nevada and California, water years 2001-02: U.S. Geological Survey Scientific Investigations Report 2004-5186, 86 p., also available at http://pubs.usgs.gov/sir/2004/5186/.

Armin, R.A., and John, D.A., 1983, Geologic map of the Freel Peak 15-minute quadrangle, California and Nevada: U.S. Geological Survey Miscellaneous Investigations Series Map 1-1424, 1:62,500 scale.

BAE Systems Advanced Technologies, Inc., 2004, Carson Valley Conservation District hyperspectral and LiDAR imaging, Final Report, October 28, 2004: Washington, D.C., $113 \mathrm{p}$.

Belcher, W.R., ed., 2004, Death Valley regional ground-water flow system, Nevada and California-Hydrogeologic framework and transient ground-water flow model: U.S. Geological Survey Scientific Investigations Report 20045205,408 p.

Berger, D.L., 1987, Ground-water levels in water years 1984-86 and estimated ground-water pumpage in water years 1984-85, Carson Valley, Douglas County, Nevada: U.S. Geological Survey Open-File Report 86-539, 16 p.

Berger, D.L., 1990, Ground-water levels in water year 1987 and estimated ground-water pumpage in water years 1986-87, Carson Valley, Douglas County, Nevada: U.S. Geological Survey Open-File Report 89-70, 9 p.

Berger, D.L., and Medina, R.L., 1999, Spatial ground-water data base in Carson Valley, Douglas County, Nevada, and Alpine County, California-Development and documentation: U.S. Geological Survey Water-Resources Investigations Report 99-4188, 1 CD-ROM.

Clark, S.N., 2006, Carson Valley groundwater pumpage inventory, water year 2005: Nevada Department of Conservation and Natural Resources, Division of Water Resources, 85 p.

Cooper, H.H., and Jacob, C.E., 1946, A generalized graphical method for evaluating formation constants and summarizing well field history: American Geophysical Transactions, v. 27, p. 526-534.

dePolo, C.M., Ramelli, A.R., and Muntean, Thomas, 2000, Preliminary geologic map of the Gardnerville quadrangle, Douglas County, Nevada: Nevada Bureau of Mines and Geology Open-File Report 2000-9, 1:24,000 scale.
Dettinger, M.D., Cayan, D.R., Meyer, M.K., and Jeton, A.E., 2004, Simulated hydrologic responses to climate variations and change in the Merced, Carson, and American River Basins, Sierra Nevada, California, 1900-2099: Climate Change, v. 62, p. 283-317.

Dillingham, H.L., 1980, Washoe Project, Nevada-California, ground-water geology and resources, definite plan appendix, Carson Valley, Nevada: U.S. Bureau of Reclamation, Sacramento, California, $82 \mathrm{p}$.

Doherty, John, 2003, Ground water model calibration using pilot points and regularization: Ground Water, v. 41, issue 2, p. 170-177. doi:10.1111/j.1745-6584.2003. tb02580.x, also available at http://onlinelibrary.wiley.com/ doi/10.1111/j.1745-6584.2003.tb02580.x/abstract.

EcoLogic, 2000, East Valley water system- Heybourne well site analysis and recommendations for wellfield development: Consultant engineering memorandum to Douglas County Community Development, Douglas County, Nevada, Aug. 29, 2000: ECO:LOGIC Engineering, LLC, Reno, Nevada, 18 p.

EcoLogic, 2001a, Sunrise Estates well tests: Consulting engineers report to Douglas County Community Development, Douglas County, Nevada, June 15, 2001: ECO:LOGIC Engineering, LLC, Reno, Nevada, 17 p.

EcoLogic, 2001b, Old Airport well test: Consultant engineering memorandum to Douglas County Community Development, Douglas County, Nevada, Oct. 9, 2001: ECO:LOGIC Engineering, LLC, Reno, Nevada, 6 p.

EcoLogic, 2001c, Walley’s Hot Springs well test: Consultant engineering memorandum to Douglas County Community Development, Douglas County, Nevada, Nov. 26, 2001 : ECO:LOGIC Engineering, LLC, Reno, Nevada, 7 p.

EcoLogic, 2002a, Douglas County North Valley improvements Topsy Lane well 2 construction and testing: Consulting engineers report to Douglas County Community Development, Douglas County, Nevada, Jan. 24, 2002: ECO:LOGIC Engineering, LLC, Reno, Nevada, 23 p., 8 appendices.

EcoLogic, 2002b, Analysis of Little Mondeaux/Simek well test data: Consulting engineers report to Douglas County Community Development, Douglas County, Nevada, Nov. 22, 2002: ECO:LOGIC Engineering, LLC, Reno, Nevada, $5 \mathrm{p}$.

EcoLogic, 2003a, South Airport exploratory well no. 2, construction and testing: Consulting engineers memorandum report to Douglas County Community Development, Douglas County, Nevada, Mar. 28, 2003: ECO:LOGIC Engineering, LLC, Reno, Nevada, 18 p. 
EcoLogic, 2003b, East Topsy Lane monitoring well construction and testing: Consulting engineers memorandum report to Douglas County Community Development, Douglas County, Nevada, July 28, 2003: ECO:LOGIC Engineering, LLC, Reno, Nevada, 24 p., 6 appendices.

EcoLogic, 2004a, Job's Peak Ranch well evaluation - Phase I, Consulting engineers report to Douglas County Community Development, Douglas County, Nevada, Feb. 17, 2004 : ECO:LOGIC Engineering, LLC, Reno, Nevada, 18 p.

EcoLogic, 2004b, Hollister well test: Consulting engineers memorandum to Douglas County Community Development, Douglas County, Nevada, Aug. 2, 2004: ECO:LOGIC Engineering, LLC, Reno, Nevada, 16 p., 1 appendix.

EcoLogic, 2005, North Valley Production well \#2, East Topsy Lane construction and testing: Consulting engineers report to Douglas County Community Development, Douglas County, Nevada, July 14, 2005: ECO:LOGIC Engineering, LLC, Reno, Nevada, 27 p., 1 appendix.

Economic Research Service, 2007, County-level population data for Nevada at http://www.ers.usda.gov/data-products/ county-level-data-sets, accessed December 18, 2012.

Garside, L.J., and Rigby, J.G., 1998, Preliminary geologic map of the McTarnahan Hill quadrangle, Nevada: Nevada Bureau of Mines and Geology, Open-File Report 99-5, 1:24,000 scale.

Glancy, P.A., and Katzer, T.L., 1976, Water-resources appraisal of the Carson River basin, Western Nevada: Nevada Department of Conservation and Natural Resources, Water Resources-Reconnaissance Series Report 59, 126 p.

Guitjens, J.C., and Mahannah, C.N., 1972, Upper Carson River water study, water year 1972: Max C. Fleischmann College of Agriculture, University of Nevada, Reno, Report 94, $51 \mathrm{p}$.

Guitjens, J.C., Mahannah, C.N., and Miller, W.W., 1976, Quality monitoring of irrigation water and return flows, irrigation season 1974: Max C. Fleischmann College of Agriculture, University of Nevada, Reno, Report 114, 46 p.

Guitjens, J.C., Miller, W.W., Joung, H.M., and Mahannah, C.N., 1978, Quality monitoring of irrigation water and return flows, irrigation season 1975: Max C. Fleischmann College of Agriculture, University of Nevada, Reno, Report $119,74 \mathrm{p}$.

Halford, K.J., and Kuniansky, E.L., 2002, Documentation of spreadsheets for the analysis of aquifer pumping and slug test data: U.S. Geological Survey Open-File Report 02-197, $54 \mathrm{p}$.
Halford, K.J., and Plume, R.W., 2011, Potential effects of groundwater pumping on water levels, phreatophytes, and spring discharges in Spring and Snake Valleys, White Pine County, Nevada, and adjacent areas in Nevada and Utah: U.S. Geological Survey Scientific Investigations Report 2011-5032, $52 \mathrm{p}$.

Harbaugh, A.W., 2005, MODFLOW-2005, The U.S. Geological Survey modular ground-water model - the GroundWater Flow Process: U.S. Geological Survey Techniques and Methods 6-A16, variously paged.

Hess, G.W., and Taylor, R.L., 1999, River-operations model for the upper Carson River basin, California and Nevada: U.S. Geological Survey Water-Resources Investigations Report 98-4240, $40 \mathrm{p}$.

Hill, M.C., 1998, Methods and guidelines for effective model calibration: U.S. Geological Survey Water-Resources Investigations Report 98-4005, 90 p.

Hydro Geo-Chem Inc., 1988, Well hydraulics interpretation package, version 3.22: computer program for the analysis of pumping test data.

Jeton, A.E., Dettinger, M.D., and Smith, J.L., 1996, Potential effects of climate change on streamflow, eastern and western slopes of the Sierra Nevada, California and Nevada: U.S. Geological Survey Water Resource Investigations Report, 95-4260, $49 \mathrm{p}$.

Jeton, A.E., and Maurer, D.K., 2007, Precipitation and runoff simulations of the Carson Range and Pine Nut Mountains, and updated estimates of ground-water inflow and the ground-water budget for basin-fill aquifers of Carson Valley, Douglas County, Nevada, and Alpine County, California: U.S. Geological Survey Scientific Investigations Report 2007-5205, 55 p.

Leavesley, G.H., Litchy, R.W., Troutman, M.M., and Saindon, L.G., 1983, Precipitation-runoff modeling system-User's manual: U.S. Geological Survey Water Resources Investigations Report 83-4238, 207 p.

Lee, John, 1982, Well testing: Society of Petroleum Engineers of AIME, New York, $159 \mathrm{p}$.

Lohman, S.W., 1972, Ground water hydraulics: U.S. Geological Survey Professional Paper 708, 70 p.

Maurer, D.K., 1984, Gravity survey and depth to bedrock in Carson Valley, Nevada- California: U.S. Geological Survey Water-Resources Investigations Report 84-4202, 20 p.

Maurer, D.K., 1986, Geohydrology and simulated response to ground-water pumpage in Carson Valley, a river-dominated basin in Douglas County, Nevada, and Alpine County, California: U.S. Geological Survey Water-Resources Investigations Report 86-4328, 109 p. 
Maurer, D.K., and Berger, D.L., 1997, Subsurface flow and water yield from watersheds tributary to Eagle Valley Hydrographic Area, west-central Nevada: U.S. Geological Survey Water-Resources Investigations Report 97-4191, $56 \mathrm{p}$.

Maurer, D.K., and Berger, D.L., 2007, Water budgets and potential effects of water use changes for Carson Valley, Douglas County, Nevada, and Alpine County, California: U.S. Geological Survey Scientific Investigations Report 2006-5305, 63 p. Available at http://pubs.usgs.gov/ sir/2006/5305/index.html.

Maurer, D.K., Berger, D.L., Tumbusch, M.L., and Johnson, M.J., 2006, Rates of evapotranspiration, recharge from precipitation beneath selected areas of native vegetation, and streamflow gain and loss in Carson Valley, Douglas County, Nevada, and Alpine County, California: U.S. Geological Survey Scientific Investigations Report 2005-5288, 70 p.

Maurer, D.K., and Halford, K.J., 2004, Updated estimates of the distribution of average annual precipitation in Carson Valley, 1971-2000, Douglas County, Nevada, and Alpine County, California: Journal of the Nevada Water Resources Association, v. 1, no. 1, p. 20-39.

Maurer, D.K., Paul, A.P., Berger, D.L., and Mayers, C.J., 2009, Analysis of streamflow trends, ground-water and surfacewater interactions, and water quality in the upper Carson River Basin, Nevada and California: U.S. Geological Survey Scientific Investigations Report 2008-5238, 192 p.

Maurer, D.K., and Peltz, L.A., 1994, Potential for, and possible effects of, artificial recharge in Carson Valley, Douglas County, Nevada: U.S. Geological Survey Water-Resources Investigations Report 94-4126, 4 map sheets.

Maurer, D.K., Watkins, S.A., and Burrows, R.L., 2004, Updated computations and estimates of streamflows tributary to Carson Valley, Douglas County, Nevada, and Alpine County, California: U.S. Geological Survey Scientific Investigations Report 2004-5179, 29 p.

Moore, J.G., 1969, Geology and mineral deposits of Lyon, Douglas, and Ormsby Counties, Nevada: Nevada Bureau of Mines and Bulletin 75, $42 \mathrm{p}$.

Morris, D.A., and Johnson, A.I., 1967, Summary of hydrologic and physical properties of rock and soil materials, as analyzed by the hydrologic laboratory of the U.S. Geological Survey, 1948-60: U.S. Geological Survey Water-Supply Paper 1839-D, $42 \mathrm{p}$.

Muntean, T.W., 2001, Evolution and stratigraphy of the Neogene Sunrise Pass Formation of the Gardnerville sedimentary basin, Douglas County, Nevada: University of Nevada, Reno, unpublished Master's thesis, 206 p.
Naff, R.L., and Banta, E.R., 2008, The U.S. Geological Survey modular ground-water model-PCGN: A preconditioned conjugate gradient solver with improved nonlinear control: U.S. Geological Survey Open-File Report 2008-1331, 35 p.

National Oceanic and Atmospheric Administration, 2002, Monthly station normals of temperature, precipitation, and heating and cooling degree days, 1971-2000, Climatology of the United States, No. 81, Nevada: National Climatic Data Center, Asheville, North Carolina, 26 p.

National Oceanic and Atmospheric Administration, 2006, National Climate Data Center, Palmer Drought Severity Index: National Oceanic and Atmospheric Administration, accessed March 7, 2006, at http://www.drought.noaa.gov. Note: This site will no longer be updated, but will remain archived. For the latest drought information, please visit the National Integrated Drought Information System.

Niswonger, R.G., Panday, Sorab, and Ibaraki, Motomu, 2011, MODFLOW-NWT, A Newton Formulation for MODFLOW-2005: U.S. Geological Survey Techniques and Methods 6-A37, $44 \mathrm{p}$.

Niswonger, R.G., and Prudic, D.E., 2005, Documentation of the Streamflow-Routing (SFR2) Package to include unsaturated flow beneath streams-A modification to SFR1 (revised April 2010): U.S. Geological Survey Techniques and Methods, book 6, chap. A13, 50 p.

Paul, A.P., Maurer, D.E., Stollenwerk, K.G., and Welch, A.H., 2010, In-situ arsenic remediation in Carson Valley, Douglas County, west-central Nevada: U.S. Geological Survey Scientific Investigations Report 2010-5161, 24 p.

Pease, R.C., 1980, Geologic map, Genoa quadrangle, Nevada: Nevada Bureau of Mines and Geology Urban Map Series, Genoa Folio, Map 1Cg., scale 1:24,000.

Poeter, E.P., Hill, M.C., Banta, E.R., Mehl, S., and Christensen, S., 2005, UCODE_2005 and six other computer codes for universal sensitivity analysis, calibration and uncertainty evaluation: U.S. Geological Survey Techniques and Methods 6-A11, $283 \mathrm{p}$.

Prudic, D.E., and Herman, M.E., 1996, Ground-water flow and simulated effects of development in Paradise Valley, a basin tributary to the Humboldt River in Humboldt County, Nevada: U.S. Geological Survey Professional Paper 1409-F, $103 \mathrm{p}$.

Prudic, D.E., and Wood. J.L., 1995, Results of hypothetical ground-water pumping in Carson Valley, a river-dominated basin in Douglas County, Nevada, and Alpine County, California: U.S. Geological Survey Water-Resources Investigations Report 95-4174, 29 p.

Stewart, J.H., 1980, Geology of Nevada: Nevada Bureau of Mines and Geology Special Publications 4, 135 p. 
Stewart, J.H., 1999, Geologic map of the Carson City 30 x 60 minute quadrangle, Nevada: Nevada Bureau of Mines and Geology, map 118, 1:100,000 scale, and accompanying text and references, $12 \mathrm{p}$.

Stewart, J.H., and Carlson, J.E., 1978, Geologic map of Nevada: U.S. Geological Survey, prepared in cooperation with the Nevada Bureau of Mines and Geology, 1:500,000 scale, 2 sheets.

Stewart, J.H., and Noble, D.C., 1979, Preliminary geologic map of the Mount Siegel quadrangle, Nevada-California: U.S. Geological Survey Open-File Report 79-225, 1:62,500 scale.

Thomas, K.A., and Williams, R.P., 1997, Flood of January 1997 in the Carson River basin, California and Nevada: U.S. Geological Survey Fact Sheet, FS-183-97, 2 p.

Unger, K.L., 2006, A holistic approach to balancing growth, agriculture and the environment in the upper Carson River basin: University of Nevada, Reno, unpublished Ph.D. dissertation, $264 \mathrm{p}$.

U.S. District Court, 1980, Findings of fact, conclusions of law, tabulation and administrative provisions, United States vs. Alpine Land and Reservoir Company, Final Decree: Civil no. D-183 BRT, $164 \mathrm{p}$.

U.S. Geological Survey, 2003, Quaternary fault and fold database of the United States: U.S. Geological Survey OpenFile Report 03-417, http://earthquake.usgs.gov/hazards/ qfaults/. 


\section{Appendix 1. Modifications to MODFLOW}

This appendix describes the changes made to the MODFLOW-2005 code to (1) enable simulation of recharge by applying diversions defined in the Streamflow Routing (SFR2) package directly to a defined group of model cells (diverted recharge), and (2) include an irrigation-efficiency term that decreases the volume of diverted water that is applied to account for losses through return flow and crop evapotranspiration. The changes required in the SFR2 input file are also described. These features are not available in the standard version of MODFLOW-2005 (Harbaugh, 2005, Version 1.8). At each diversion segment in SFR2, a specified flow $\left[\mathrm{L}^{3} / \mathrm{T}\right]$ is normally routed to one of the following: another segment, lake cells, or outside the model domain. The modification described herein also allows flow to be applied evenly over a group of model cells, assuming sufficient flow is available in the stream segment. The recharge rate is calculated as the total flow diversion, divided by the total cell area $[\mathrm{L} / \mathrm{T}]$ (number of cells multiplied by the cell areas). In addition, this diverted recharge is subject to a user-defined efficiency factor that removes a portion of the flow from the model domain to represent evapotranspiration losses. Note all changes and additions are shown in bold below.

\section{Main program: $\mathrm{mf2005.f}$}

Under section C7B-----READ AND PREPARE INFORMATION FOR STRESS PERIOD. READ USING PACKAGE READ AND PREPARE MODULES, the SFR unit number was added for use by the recharge package.

IF(IUNIT(8).GT.0) CALL GWF2RCH7RP(IUNIT(8),IUNIT(44),IGRID)

Under section C7C2A---FORMULATE THE FINITE DIFFERENCE EQUATIONS.S, the RCH unit number was added for use by the SFR package.

1

IF(IUNIT(44).GT.0) CALL GWF2SFR7FM(KKITER,KKPER,KKSTP,

IUNIT(22),IUNIT(8),IGRID)

Under section C7C4----CALCULATE BUDGET TERMS. SAVE CELL-BY-CELL FLOW TERMS. add SFR and RCH unit numbers

CALL GWF2RCH7BD(KKSTP,KKPER,IUNIT(44),IGRID)

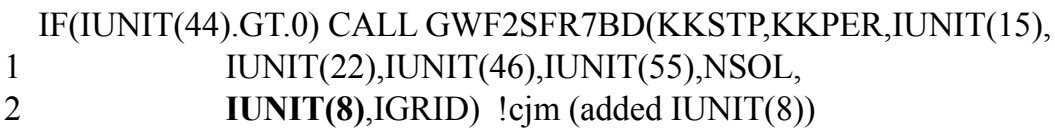

\section{RCH Module: gwf2rch7.f}

In specifications under SUBROUTINE GWF2RCH7RP define RECHSAVE array. This array is used to store the original recharge array data and account for the diverted recharge from SFR2

USE GLOBAL， ONLY:IOUT,NCOL,NROW,NLAY,IFREFM,DELR,DELC

USE GWFRCHMODULE,ONLY:NRCHOP,NPRCH,IRCHPF,RECH,IRCH

USE GWFSFRMODULE,ONLY:RECHSAVE 
Under section C4------MULTIPLY RECHARGE RATE BY CELL AREA TO GET VOLUMETRIC RATE, insert the bolded line below to initialize the RECHSAVE array with the RECH array values.

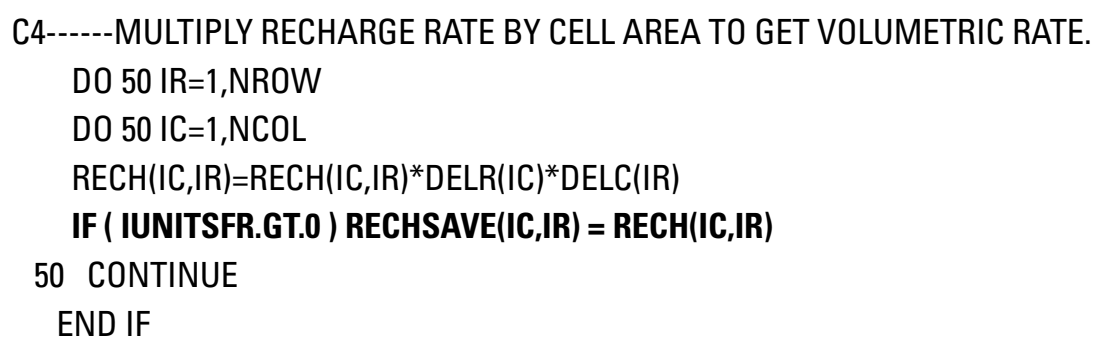

In specifications under SUBROUTINE GWF2RCH7BD defined a number of new variables.

USE GLOBAL， ONLY:IOUT,NCOL,NROW,NLAY,IBOUND,BUFF, iout USE GWFBASMODULE,ONLY:MSUM,VBVL,VBNM,ICBCFL,DELT,PERTIM,TOTIM

USE GWFRCHMODULE,ONLY:NRCHOP,IRCHCB,RECH,IRCH

USE GWFSFRMODULE,ONLY:RECHSAVE

C

DOUBLE PRECISION RATIN,RATOUT,Q0, 0, rin2, zero

CHARACTER* ${ }^{*} 6$ TEXT

DATA TEXT /' RECHARGE'/

CHARACTER*16 txtsfrch

DATA txtsfrch/' SFR RECHARGE'/

INTEGER IUNITSFR

Under SUBROUTINE GWF2RCH7BD in section C2------CLEAR THE RATE ACCUMULATORS, initialize several variables to zero.

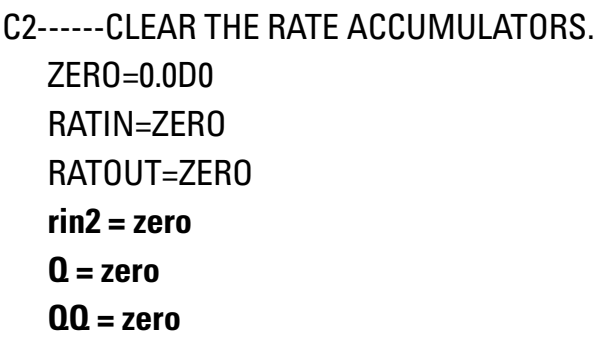

Under SUBROUTINE GWF2RCH7BD in section C5A-----IF CELL IS VARIABLE HEAD, THEN DO BUDGET FOR IT, calculate budget for variable head cell

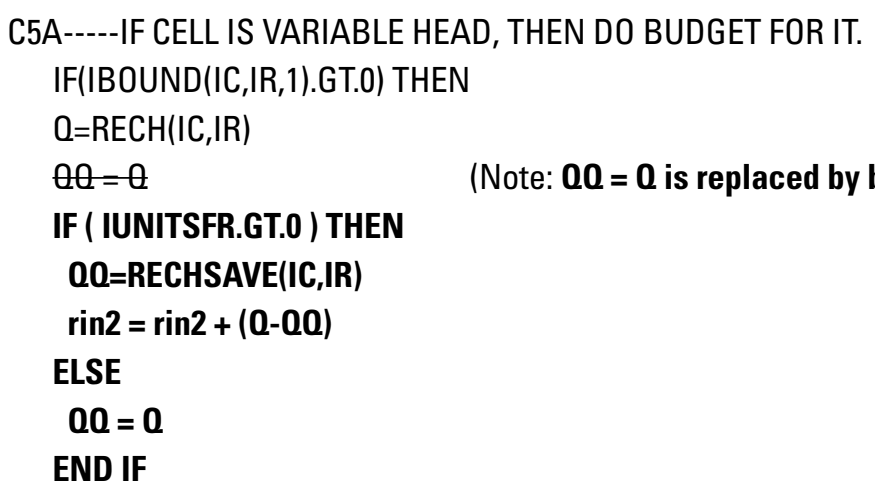


Under SUBROUTINE GWF2RCH7BD in C6B-----IF CELL IS VARIABLE HEAD, THEN DO BUDGET FOR IT., calculate budget for variable head cell

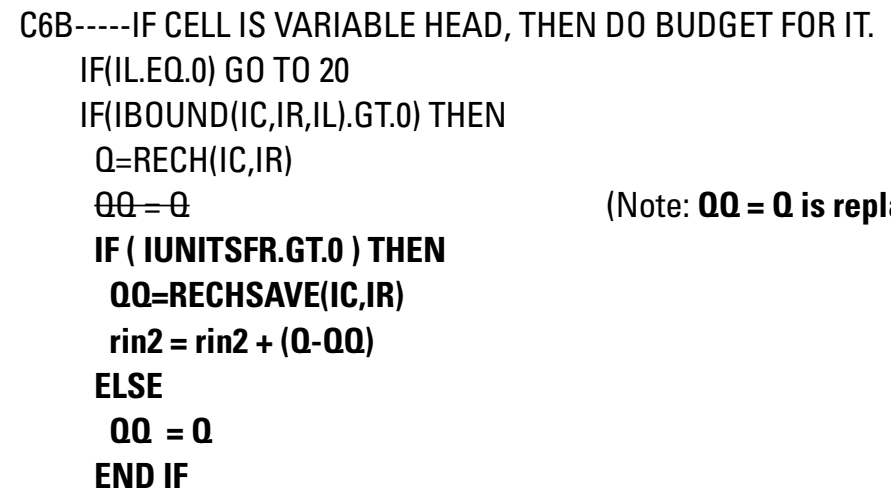

Under SUBROUTINE GWF2RCH7BD in C6D-----IF RECHARGE IS POSITIVE ADD TO RATIN, ELSE ADD IT TO RATOUT, calculate budget for variable head cell

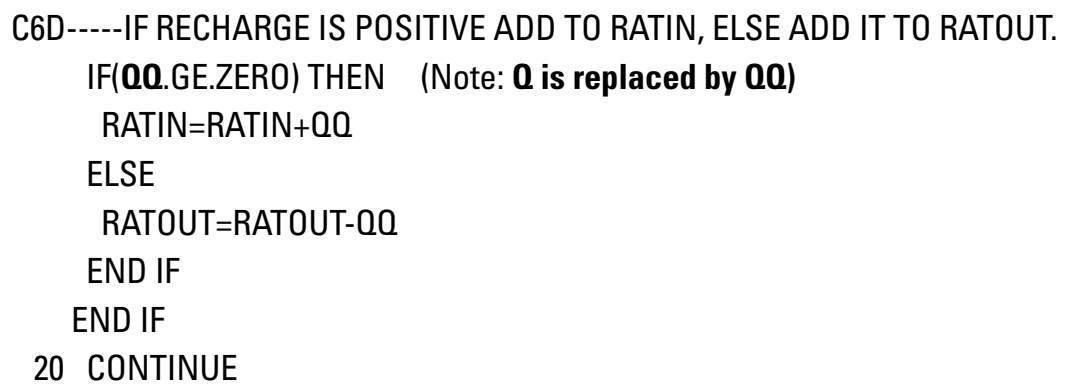

Under SUBROUTINE GWF2RCH7BD in C7C-----IF CELL IS VARIABLE HEAD, THEN DO BUDGET FOR IT, calculate budget for variable head cell

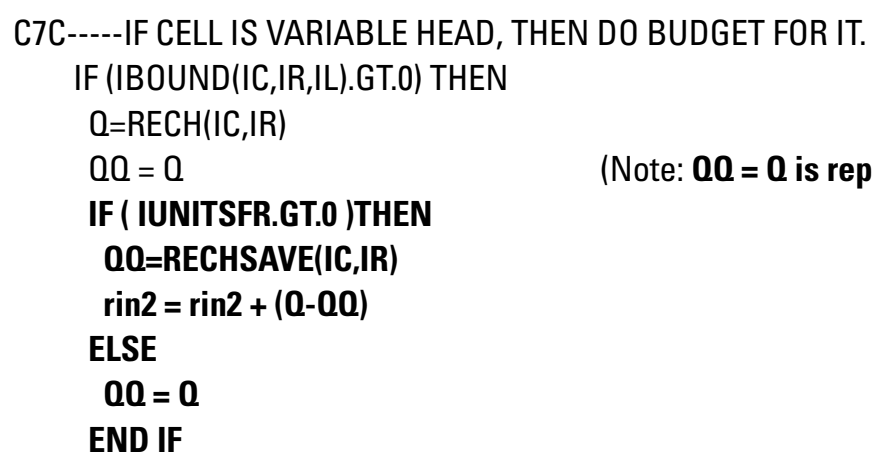

Under SUBROUTINE GWF2RCH7BD in C7E-----IF RECH IS POSITIVE ADD IT TO RATIN, ELSE ADD IT TO RATOUT, calculate budget for variable head cell

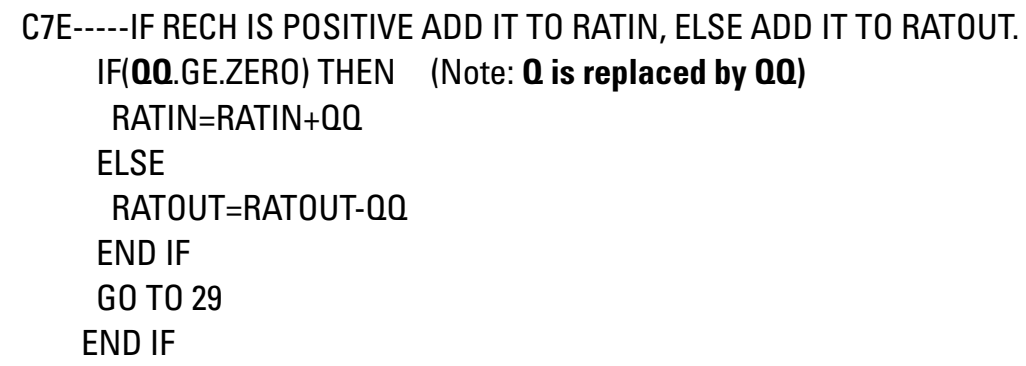


Insert code block below after C12-----INCREMENT BUDGET TERM COUNTER.

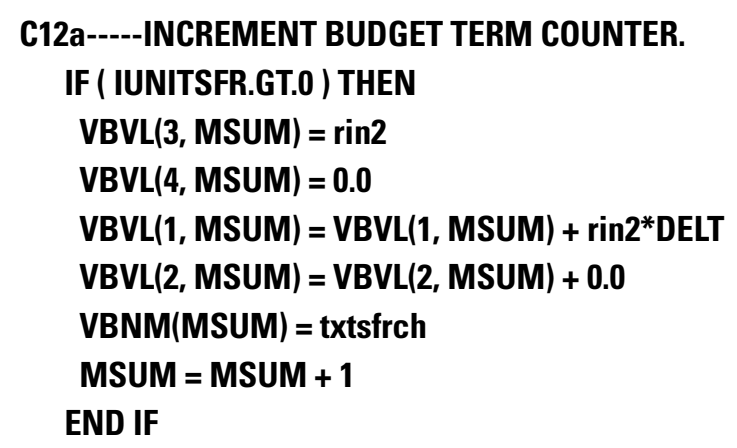

\section{SFR Module: gwfsfrmodule.f}

Allocate new variables by including the following statements under both the MODULE GWFSFRMODULE section and the TYPE GWFSFRTYPE section.

INTEGER,SAVE, DIMENSION(:), POINTER:: DVRCH

INTEGER,SAVE, DIMENSION(:,:,:),POINTER:: DVRCELL

REAL, SAVE, DIMENSION(:;),POINTER:: RECHSAVE

REAL, SAVE, DIMENSION(:),POINTER:: DVEFF

\section{SFR Module: gwf2sfr7.f}

In specifications under SUBROUTINE GWF2SFR7AR define several variables.

USE GWFSFRMODULE

USE GLOBAL， ONLY: IOUT, IBOUND, BOTM, STRT, DELR, DELC, $+\quad$ ITRSS,NCOL,NROW

Under C5------CALCULATE SPACE NEEDED FOR TABULATED DISCHARGE VERSUS FLOW in the ALLOCATE ARRAY STORAGE section add the following lines to allocate and initialize several variables

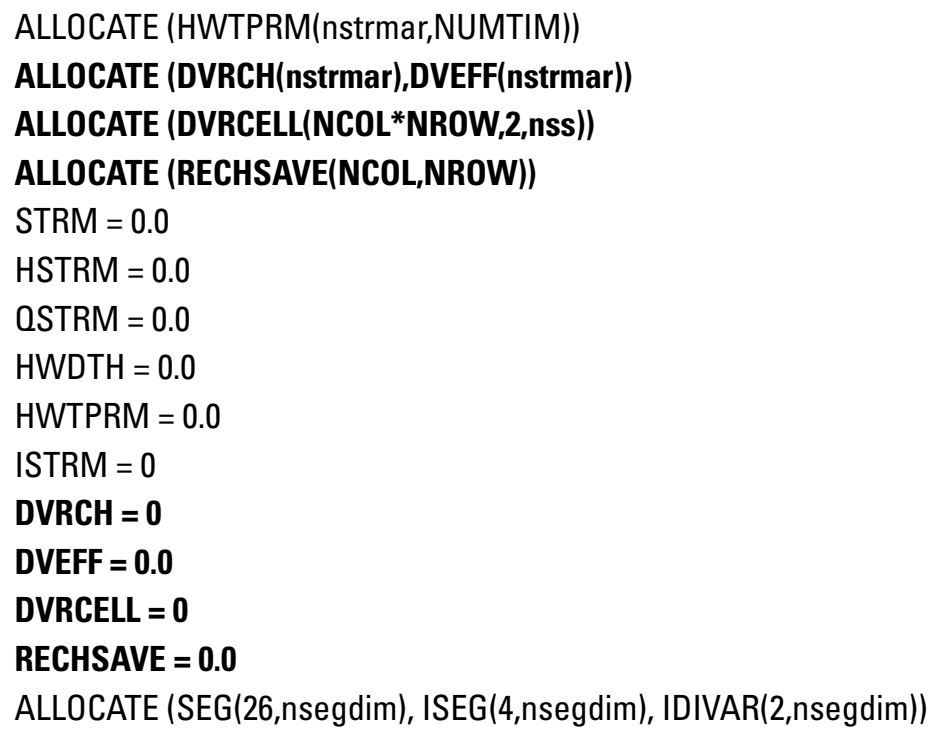


In subroutine GWF2SFR7FM make the following changes

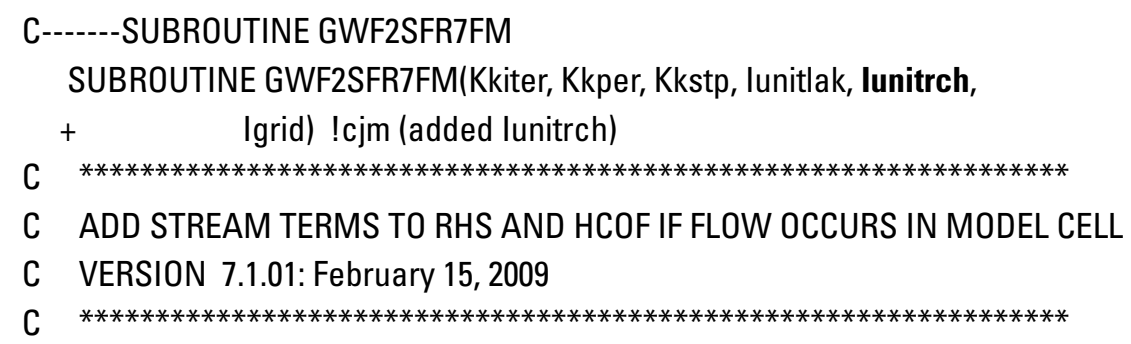

USE GWFRCHMODULE,ONLY:RECH

USE GWFSFRMODULE

In arguments under subroutine GWF2SFR7FM add the following argument

INTEGER Kkiter, Kkper, lunitlak, Igrid, Kkstp, lunitrch

In local variables under subroutine GWF2SFR7FM add the following variables

REAL areamax, avhc, errold, fks, ha, qcnst, seep,

+ stgon, strlen, roughch, roughbnk, widthch, deltinc, qlat,

+ fltest, Transient_bd, dvt

! real fin, fout

INTEGER i, ibflg, ic, icalc, idivseg, iflg, iic, iic2, iic3, iic4,

$+\quad$ il, ilay, iprior, iprndpth, iprvsg, ir, istsg, itot,itrib,

$+\quad$ itstr, iwidthcheck, kerp, kss, I, lk, II, nstrpts, nreach,

$+\quad$ maxwav, icalccheck, iskip, iss, Isub, numdelt, irt, ii,

$+\quad$ idr, lfold

INTEGER irr, icc, icount

DOUBLE PRECISION FIVE_THIRDS

Under subroutine GWF2SFR7FM insert code block below after C20-----SET FLOW INTO DIVERSION IF SEGMENT IS DIVERSION.

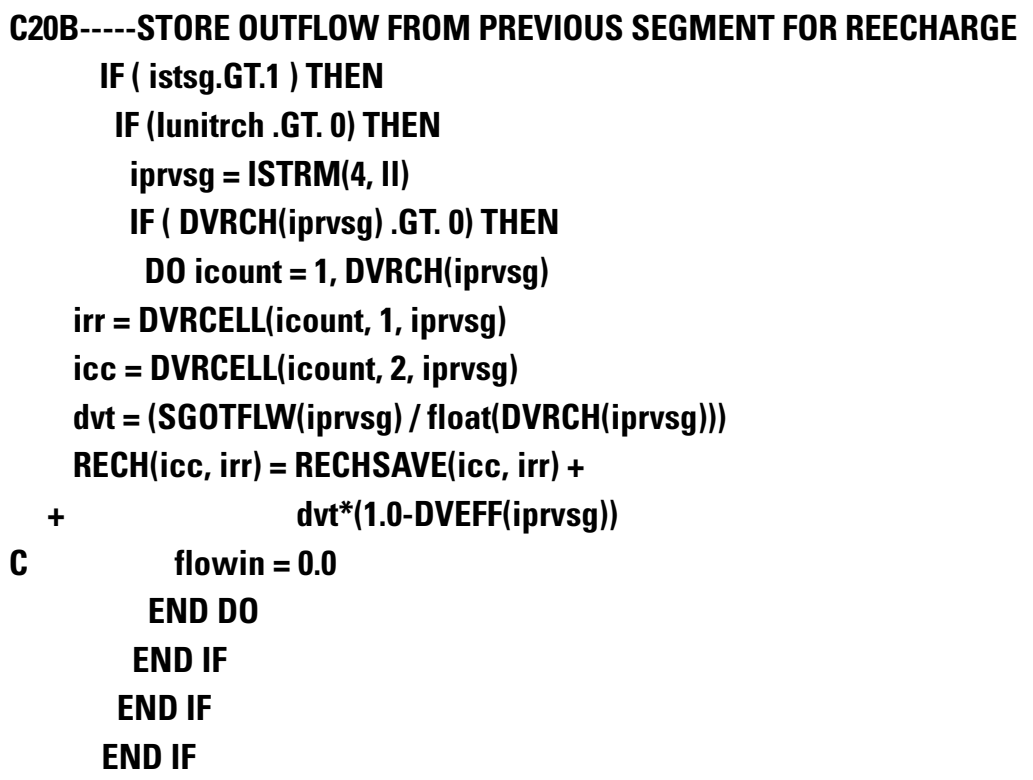


In subroutine GWF2SFR7BD make the following changes

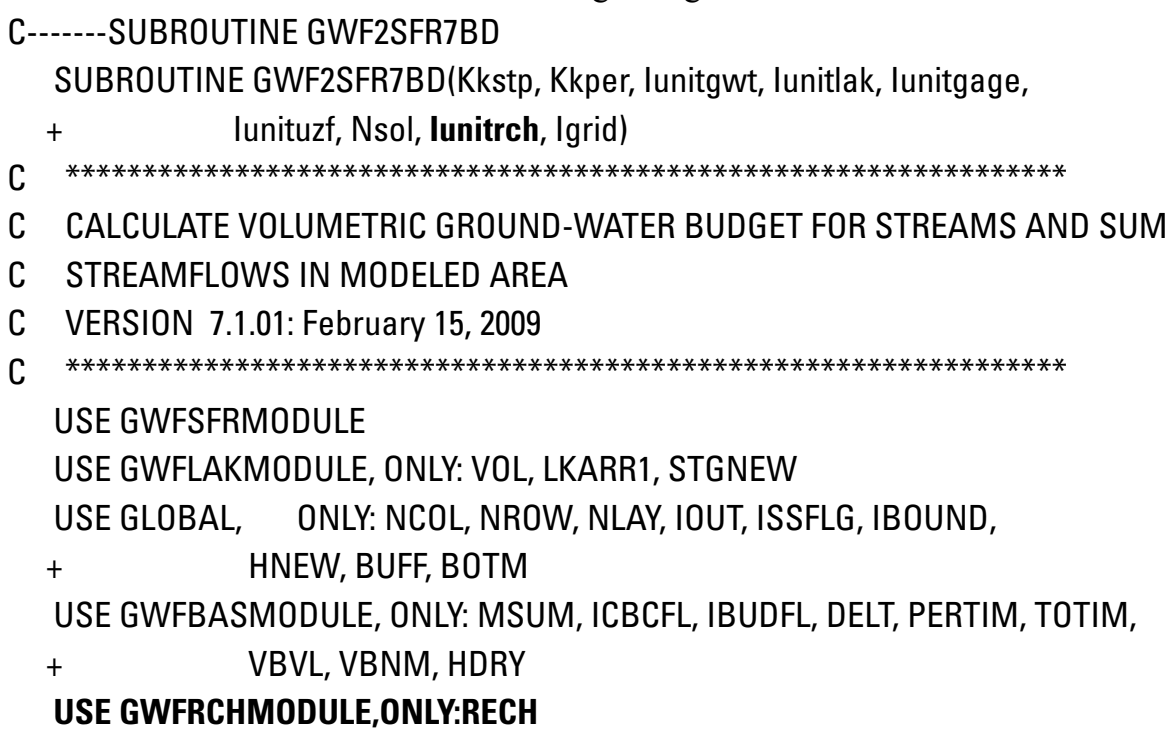

In arguments under subroutine GWF2SFR7BD add the following argument

INTEGER Kkstp, Kkper, lunitgwt, lunitlak, lunitgage, lunituzf, $+\quad$ lunitrch

In local variables under subroutine GWF2SFR7BD add the following variables

REAL areamax, avhc, fks, ha, rin, rout, strlen,

+ zero,sfrbudg_in, sfrbudg_out, qlat, deltinc, qcnst, rtime,

+ fltest, Transient_bd, Transient_bd_tot, dvt

INTEGER i, ibd, iblst, ibdlbl, ibdst, ibstlb, ic, icalc, idivseg,

$+\quad$ il, ilay, iout1, iout2, iprior, iprvsg, ir, istsg, itrib,

$+\quad$ iwidthcheck, kss, I, Ik, II, nreach, numdelt, maxwav,

$+\quad$ icalccheck, iss, Isub, irt, itstr, imassroute, Ifold

INTEGER irr, icc, icount

Under subroutine GWF2SFR7BD insert code block below after C20-----SET FLOW INTO DIVERSION IF SEGMENT IS DIVERSION.

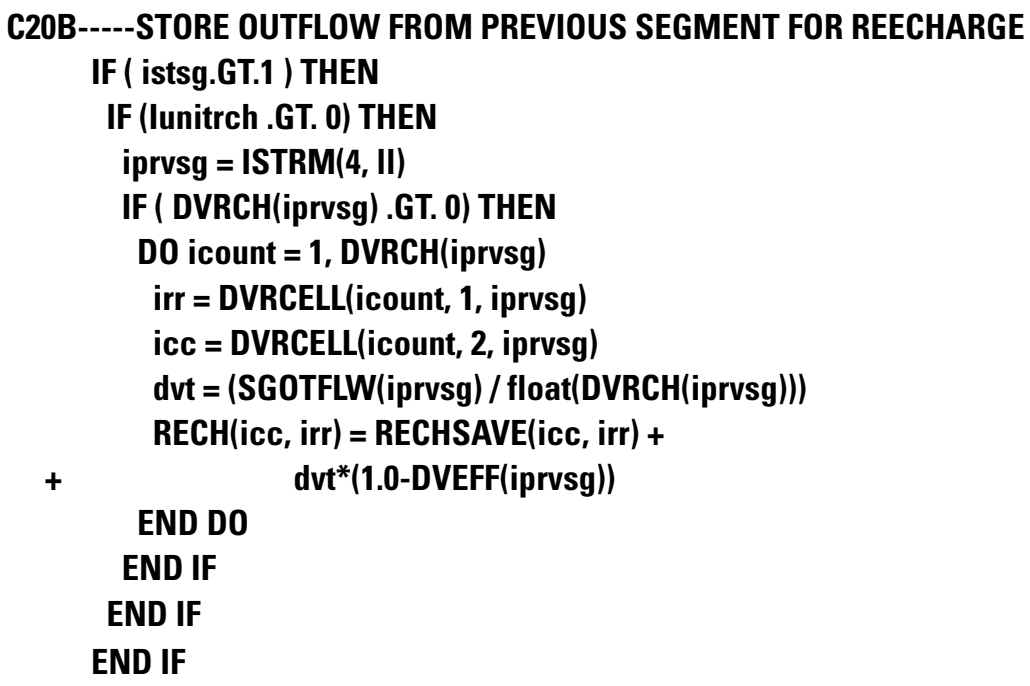


In subroutine SGWF2SFR7RDSEG make the following changes

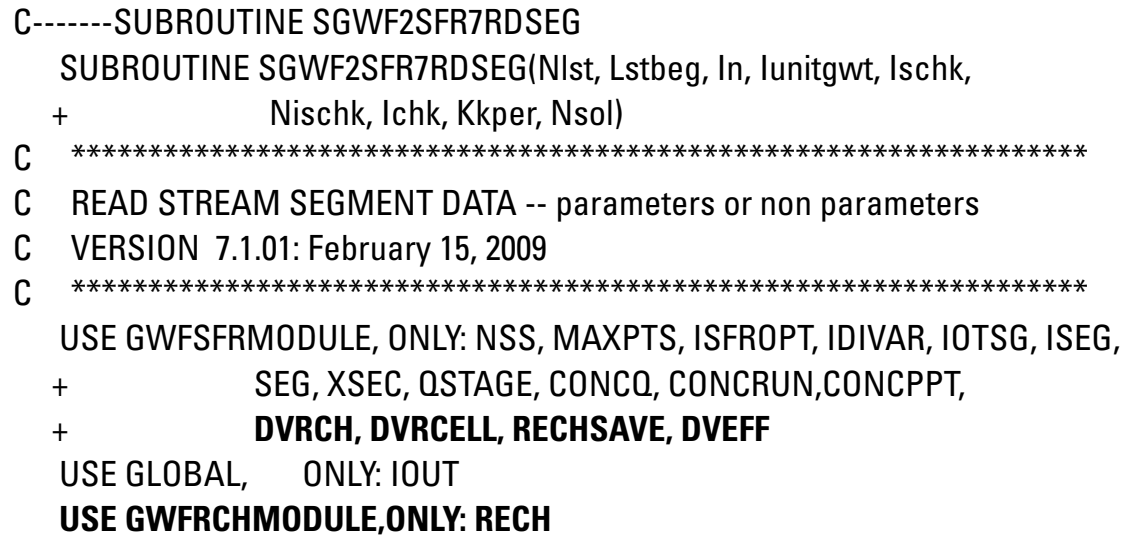

In local variables under subroutine SGWF2SFR7RDSEG add the following variables

INTEGER icalc, idum, ii, iqseg, isol, iupseg, ji, jk, lstend, n,

$+\quad$ noutseg, nseg, nstrpts, numcell, $\mathrm{i}$

Under C2------ONLY READ FIRST 4 VARIABLES TO DETERMINE VALUE OF IUPSEG. Change the following

$$
\text { HF(n.GT.NSS.OR. M.LT.1) THEN }
$$

IF ( n.GT.NSS ) THEN

Under subroutine SGWF2SFR7RDSEG insert code block below after C2------ONLY READ FIRST 4 VARIABLES TO DETERMINE VALUE OF IUPSEG.

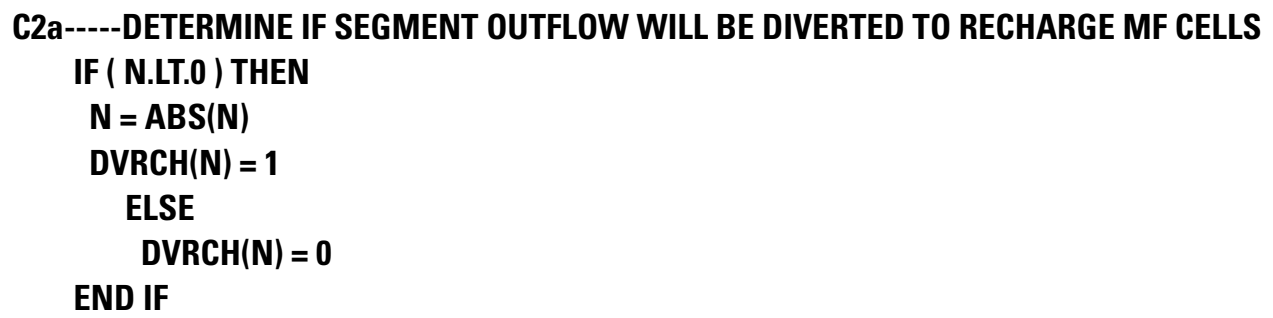

Under subroutine SGWF2SFR7RDSEG insert code block below after C10-----READ DATA SET 4G FOR SEGMENT IF SOLUTES SPECIFIED.

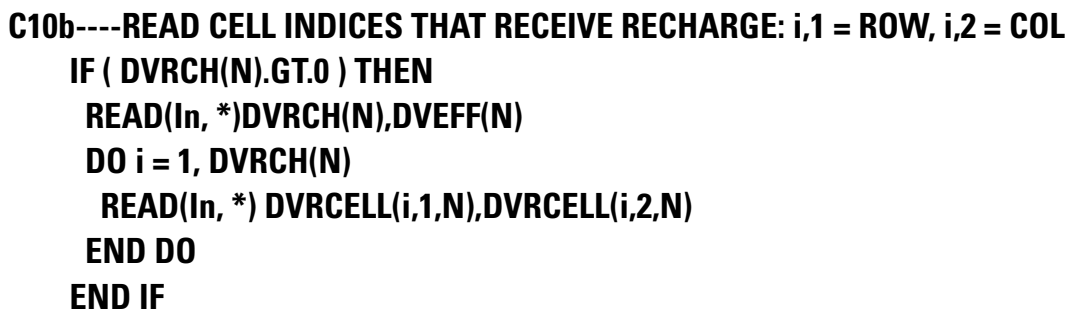

In arguments under subroutine GWF2SFR7DA add the following

DEALLOCATE (GWFSFRDAT(IGRID)\%IOTSG)

DEALLOCATE (GWFSFRDAT(IGRID)\%DVRCH)

DEALLOCATE (GWFSFRDAT(IGRID)\%DVEFF)

DEALLOCATE (GWFSFRDAT(IGRID)\%DVRCELL)

DEALLOCATE (GWFSFRDAT(IGRID)\%RECHSAVE)

DEALLOCATE (GWFSFRDAT(IGRID)\%NSEGCK) 
In arguments under subroutine GWF2SFR7PNT add the following

IOTSG=>GWFSFRDAT(IGRID)\%IOTSG
DVRCH=>GWFSFRDAT(IGRID)\%DVRCH
DVEFF=>GWFSFRDAT(IGRID)\%DVEFF
DVRCELL=>GWFSFRDAT(IGRID)\%DVRCELL
RECHSAVE=>GWFSFRDAT(IGRID)\%RECHSAVE
NSEGCK=>GWFSFRDAT(IGRID)\%NSEGCK

In arguments under subroutine SGWF2SFR7PSV add the following

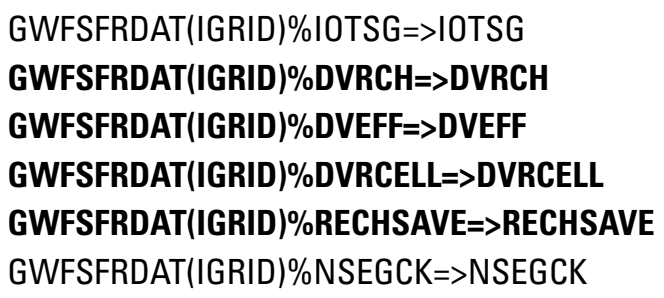

\section{SFR Input Modification}

Details of how this dataset is read by MODFLOW's SFR2 package are described below. Original documentation (Niswonger and Prudic,2005). Note this has modification has not been coded to allow for the use of parameters in the SFR package. Changes to the existing instructions in the SFR2 documentation are shown below in bold type:

For each Stress Period

Part 6a. Data: NSEG ...

NSEG An integer value of the stream segment for which information is given to identify inflow, outflow, and computation of stream depth. A negative NSEG utilizes the diverted recharge routines.

The following instructions are added to the SFR2 documentation after instructions for line $6 \mathrm{f}$ :

Part 6g. Data: NCELL EFACT

Data: NROWi NCOLi

Data: NROWj NCOLj

Data: NROWk NCOLk (repeat NCELL times)

NCELL An integer value representing the number of model cell to evenly apply diverted recharge from this segment

EFACT A real value between 0-1 that represents the efficiency factor to be applied to the diverted recharge

NROW An integer value representing the model row of the cell to receive diverted recharge

NCOL An integer value representing the model column of the cell to receive diverted recharge 


\section{Appendix 2. Modifications to PCGN Solver}

The PCGN solver (Naff and Banta, 2008) uses the preconditioned, conjugate-gradient iterative method to solve a symmetric matrix as obtained from the application of the cellcentered finite-difference scheme to a regular, three-dimensional grid. In the current version of PCGN, preconditioning is performed by means of either a modified, incomplete Cholesky algorithm with no additional fill required (MIC(0)), or one additional level of fill required (MIC(1)). The solver is attached to the MODFLOW simulator by means of an interface that, among other things, institutes an outer Picard iteration when the flow problem contains nonlinear elements. In the simplest case of nonlinear approximation, the Picard iteration is accompanied by a constant damping factor that functions to diminish overshoot in the new head estimates. For a moderately nonlinear problem, the combination of Picard iteration with constant damping usually converges rather efficiently. However, for problems with more severe nonlinear elements, Picard iteration may not converge readily to a solution. For these instances, the PCGN solver has an adaptive damping scheme whereby the amount of damping applied is made proportional to the degree of nonlinearity. That is, from measures of convergence difficulty obtained from the preceding Picard iteration, the damping can either be increased, decreased, or left unchanged; the adjusted damping is then applied to the new head solution from the current Picard iteration. This adaptive scheme, however, is rather costly in terms of execution time - as it is heavily biased toward obtaining convergence by increasing damping, thus requiring more iterations to reach convergence. For the Carson Valley model described herein, some stress-period and time-step combinations require adaptive damping in order to converge. Rather than force every stress-period and time-step combination to undergo Picard iteration with adaptive damping, a reserve adaptive damping procedure was instituted. Reserve adaptive damping is selected by setting the damping-option parameter, ADAMP, to a negative integer one.

The reserve adaptive damping procedure, as its name implies, is only called upon if Picard iteration with a constant damping does not result in convergence of the nonlinear problem in any given time step. An a priori method does not exist for determining the convergence characteristics of the Picard iteration. To quantify the difficulty of convergence, the number of Picard iterations in a time step is used; if Picard iterations become larger than a predetermined value, a switch is made from constant damping to adaptive damping. With ADAMP $=-1$, the maximum outer-iteration parameter, ITER_MO, is

1. ITER_MO, ITER_MI, CLOSE_R, CLOSE_H

2. RELAX, IFILL, UNIT_PC, UNIT_TS given a new function: ITER_MO becomes the number of Picard iterations after which the switch to adaptive damping is made. The maximum allowed number of outer (Picard) iterations under the reserve damping option becomes $4 \times$ ITER_MO. That is, Picard iteration with constant damping is given ITER_MO iterations to coverage. If convergence isn't obtained within ITER_MO iterations, then the adaptive damping procedure is instituted and an additional 3xITER_MO iterations are allowed for convergence. If after 4xITER_MO Picard iteration, the problem hasn't converged, then the MODFLOW computation is stopped.

Two operations are undertaken to facilitate the switch to adaptive damping under the reserve algorithm. First, the Picard iteration is restarted with a head distribution that is the average of the head distribution at the beginning of the time step and the head distribution obtained after ITER_MO Picard iterations with constant damping. This procedure results from the consideration that the head distribution after ITER_MO

Picard iterations could be the result of a problematic direction taken in the fixed-damping Picard iteration. Averaging the head distribution insures that the adaptive damping initiated by the reserve algorithm has an acceptable starting point. The second operation adjusts the maximum damping factor. When initiated with $A D A M P=1$, the value of DAMP is the upper limit of the damping factor under favorable convergence conditions. Under constant damping ( $A D A M P=0$ ), the value damping factor is DAMP. Because the reserve adaptive-damping scheme incorporates both concepts, the initial constant damping factor is specified as DAMP. When a switch to adaptive damping occurs, a new upper limit is set using an additional input parameter, MAX_DAMP_MOD, that has been incorporated into PCGN for this purpose. When reserve adaptive-damping is selected $(A D A M P=-1)$ and ITER_MO Picard iterations are exceeded, a new upper limit MAX_DAMP is set by: MAX_ DAMP=MAX_DAMP_MOD $x$ DAMP. For fixed damping under the reserve algorithm, it is expected that a value of DAMP close to but less than 1.0 will be selected (typically, 0.9 ). For the adaptive damping, it is generally desirable to have MAX_DAMP be a value less than 1.0 (typically, 0.5). Setting MAX_DAMP_MOD equal to MAX_DAMP/DAMP will produce the desired value of MAX_DAMP in the event that adaptive damping is initiated under the reserve algorithm.

Inputs to this modified version of PCGN are similar to the original. The following data items are required in the PCGN input file to utilize the reserve adaptive-damping option: 
An explanation of other parameters unrelated to reserve adaptive damping is described in Naff and Banta (2008). If fixed format is selected, then the corresponding format types for the preceding variables are required:

1. $2 \mathrm{I} 10,2 \mathrm{~F} 10.0$

2. $F 10.0,3110$

3. $I 10,5 F 10.0$

4. I10,F10.0,I10,F10.0,I10 

